Portland State University

PDXScholar

Dissertations and Theses

Dissertations and Theses

Summer 8-1-2016

\title{
Molecular Probes for Pancreatic Cancer Imaging
}

Lei Wang

Portland State University

Follow this and additional works at: https://pdxscholar.library.pdx.edu/open_access_etds

Part of the Chemistry Commons

Let us know how access to this document benefits you.

\section{Recommended Citation}

Wang, Lei, "Molecular Probes for Pancreatic Cancer Imaging" (2016). Dissertations and Theses. Paper 3108.

https://doi.org/10.15760/etd.3105

This Dissertation is brought to you for free and open access. It has been accepted for inclusion in Dissertations and Theses by an authorized administrator of PDXScholar. Please contact us if we can make this document more accessible: pdxscholar@pdx.edu. 
Molecular Probes for Pancreatic Cancer Imaging

by

Lei Wang

A dissertation submitted in partial fulfillment of the requirements for the degree of

Doctor of Philosophy

in

Chemistry

Dissertation Committee:

Robert M. Strongin, Chair

Erik Johansson

David Stuart

Jonathan Abramson

Portland State University

2016 
(C) 2016 Lei Wang 


\begin{abstract}
Pancreatic ductal adenocarcinoma (PDAC) has the poorest five-year survival rate of any cancer. Currently, there are no effective diagnostics or chemotherapeutics. Surgical resection is the only curative therapy. However, most patients experience recurrence due largely to challenges in assessing tumor margin status in the operating room. Molecular probes that selectively highlight pancreatic cancer tissue, having the potential to improve PDAC margin assessment intraoperatively, are urgently needed. In this work, a series of red and near-infrared fluorescent probes is reported. Two were found to distribute to normal pancreas following systemic administration. One selectively accumulates in genetically modified mouse models of PDAC, providing cancer-specific fluorescence. In contrast to the small molecule probes reported previously, it possesses inherent affinity for PDAC cells and tissue, and thus does not require conjugation to targeting agents. Moreover, the probe exhibits intracellular accumulation and enables visualization of four levels of structure including the whole organ, tissue, individual cells and subcellular organelles. It can thus promote new strategies for precision image-guided surgery, pancreatic cancer detection, the monitoring of therapeutic outcomes and basic research.
\end{abstract}




\section{ACKNOWLEDGEMENTS}

First and foremost, I would like to express my gratitude and admiration to my advisor, Professor Dr. Robert M. Strongin, who gave me opportunities, directions, encouragement, patience and understanding over the years. The joy and enthusiasm he has for his work and our lab was contagious and motivational for me, even during the tough times in my Ph.D. pursuit.

I would like to thank Dr. Jorge Escobedo and Dr. Mark Lowry, for their input in this work as well as many occasions during my research. Special thanks to Dr. Martha Sibrian-Vazquez, who has contributed immensely to my professional training and my laboratory skills.

I would like to thank both the current and past members of our research group for their constant support. This group has been a source of friendships, advice and collaborations. I am especially grateful for the former group members: Dr. Jialu Wang and Dr. Shelly Chu who made my time in the lab fun and productive. I would also like to acknowledge honorary group members that I have had the pleasure to work with: Dr. Aahba Barve, Dr. Lovemore Hakuna, and graduate students Shawna Vreeke and Ian Munhenzva.

The pancreatic cancer imaging studies discussed in this dissertation would not have been possible without the cell lines, research animals and intellectual support from Dr. Summer Gibbs at Oregon Health \& Science University. Special thanks go to her graduate student Connor Barth who I worked along with and completed animal studies. 
I would like to thank Dr. Erik Johansson, Dr. David Stuart, and Dr. Jonathan Abramson for being my committee members, I fully appreciate their precious time, insightful questions and valuable advices. I would also like to thank staff of the chemistry department, especially Tam Rankin, Lisa Sablan, and Laurie Tull, who are always ready to help.

I gratefully acknowledge the funding sources that made my $\mathrm{Ph} . \mathrm{D}$. work possible. This work was supported by grants from the V Foundation for Cancer Research, the Brenden-Colson Center for Pancreatic Care and the National Institutes of Health (via grant R15EB016870).

Lastly, I would like to thank my family for all their love and encouragement in all my pursuits. Thank you. 


\section{TABLE OF CONTENTS}

ABSTRACT i

ACKNOWLEDGEMENTS .............................................................................. ii

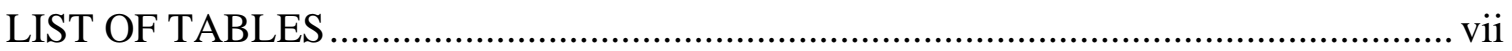

LIST OF FIGURES .............................................................................................

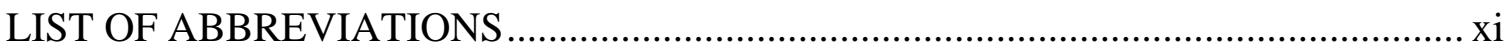

CHAPTER 1. INTRODUCTION AND PROBE DESIGN …............................................ 1

1.1 Fluorescence Image Guided Surgery for PDAC ........................................... 1

1.2 Probe Design for PDAC Imaging ………………................................... 2

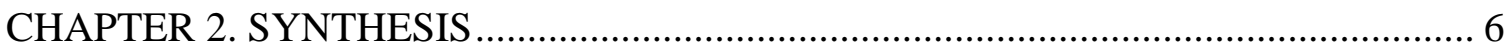

2.1 Synthesis of 2-(2,4-dihydroxybenzoyl)benzoic acid, 15 .......................... 6

2.2 Synthesis of 2-(4-amino-2-hydroxybenzoyl)benzoic acid, 17.................. 7

2.3 Synthesis of 2-(4-(dimethylamino)-2-hydroxybenzoyl)benzoic acid, 20.... 8

2.4 Synthesis of 2-(8-hydroxy-2,3,6,7-tetrahydro-1H,5H-pyrido[3,2,1ij]quinoline-9-carbonyl)benzoic acid; 22 ................................................ 9

2.5 Synthesis of 8-methoxynaphthalen-1-ol; 24 ............................................ 9

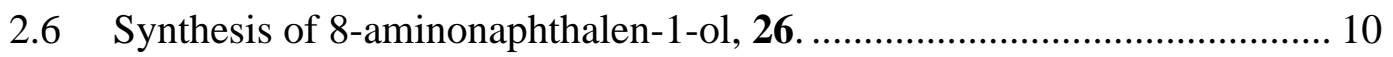

2.7 Synthesis of N-(8-hydroxynaphthalen-1-yl)acetamide, 28...................... 11

2.8 Synthesis of 8-(dimethylamino)naphthalen-1-ol, 31 ............................. 12

2.9 Synthesis of 1-hydroxy-7-(2-(methoxycarbonyl)phenyl)-10Hbenzo[c]xanthen-10-iminium chloride, 3............................................. 13

2.10 Synthesis of 1-methoxy-7-(2-(methoxycarbonyl)phenyl)-10Hbenzo[c]xanthen-10-iminium bicarbonate, 4 .

$2.11 \mathrm{~N}-(1-h y d r o x y-7-(2-(m e t h o x y c a r b o n y l) p h e n y l)-10 H-b e n z o[c] x a n t h e n-10-$ yliden)-N-N-dimethyl iminium bicarbonate, 5 ..................................... 16

$2.12 N-(1-m e t h o x y-7-(2-(m e t h o x y c a r b o n y l) p h e n y l)-10 H-b e n z o[c] x a n t h e n-10-$ ylidene )-N-methylmethanaminium chloride, 6 18 
2.13 Synthesis of methyl 2-(1-amino-10-oxo-10H-benzo[c]xanthen-7-yl)benzoate 7.

2.14 Synthesis of methyl 2-(1-(dimethylamino)-10-oxo-10H-benzo[c]xanthen-7-

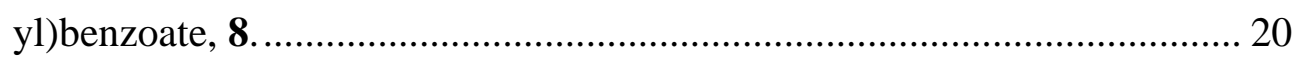

2.15 Synthesis of 1-amino-7-(2-(methoxycarbonyl)phenyl)-10Hbenzo[c]xanthen-10-iminium chloride, 9

2.16 Synthesis of N-(1-amino-7-(2-(methoxycarbonyl)phenyl)-10Hbenzo[c]xanthen -10-ylidene)-N-methylmethanaminium, $\mathbf{1 0}$. 23

2.17 Synthesis of 15-hydroxy-9-(2-(methoxycarbonyl)phenyl)-1,2,3,5,6,7hexahydrobenzo [7,8] chromeno[2,3-f]pyrido[3,2,1-ij]quinolin-4-ium chloride, 11.

2.18 Synthesis of 15-methoxy-9-(2-(methoxycarbonyl)phenyl)-1,2,3,5,6,7hexahydrobenzo[7,8]chromeno[2,3-f]pyrido[3,2,1-ij]quinolin-4-ium chloride, 12.

2.19 Synthesis of 15-amino-9-(2-(methoxycarbonyl)phenyl)-1,2,3,5,6,7hexahydrobenzo[7,8]chromeno[2,3-f]pyrido[3,2,1-ij]quinolin-4-ium chloride, $\mathbf{1 3}$. 26

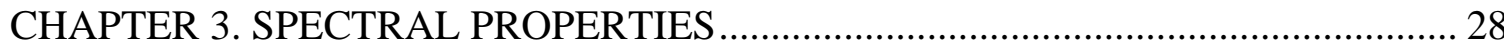

3.1 pH-dependent Spectral Properties of Dual-emitting Seminaphthofluorescein and Seminaphthorhodafluors ................................................................... 29

3.2 $\mathrm{pH}$-independent Spectral Properties of Red-emitting Methyl Ether Derivatives 34

3.3 pH-independent Spectral Properties of NIR-emitting Seminaphthorhodamines. 38

3.4 pH-dependent Spectral Properties of Transposed Seminaphthorhodafluors. 42

CHAPTER 4. PROBE IN VITRO STUDIES. 46

4.1 Structures and Calculated Physicochemical Properties Summary of 2, 12 and $\mathbf{1 3}$ 46

4.2 In Vitro Cell Viability of Compounds 2, 12 and $\mathbf{1 3}$ in Capan-1 cells 47 
4.3 In Vitro Time-dependent Fluorophore Uptake of Compounds 2, 12 and 13

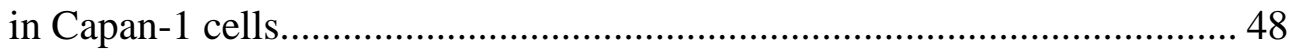

4.4 Subcellular Localization of Compounds 2, 12, and 13 in Capan-1 cells... 49

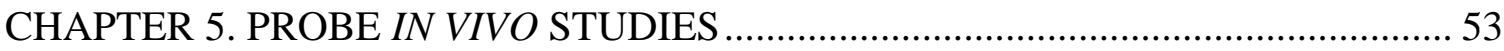

CHAPTER 6. GENETICALLY ENGINEERED MOUSE MODELS OF PDAC

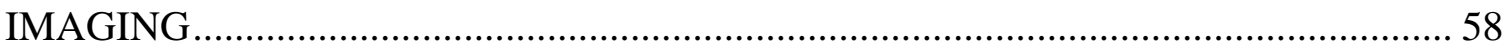

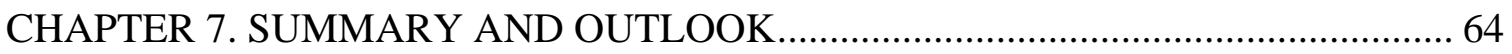

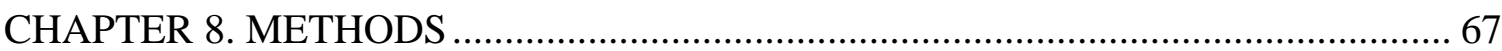

8.1 Physicochemical Property Prediction and Molecular Modeling. .............. 67

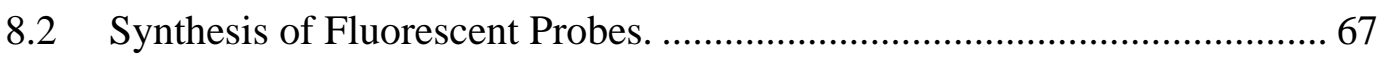

8.3 UV-Vis Absorption and Fluorescence Spectroscopy. ............................... 68

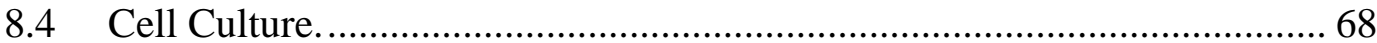

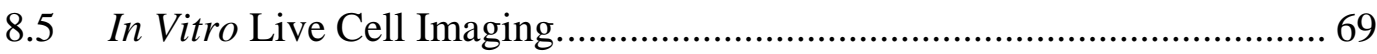

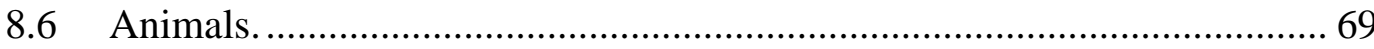

8.7 Intraoperative Fluorescence Imaging System......................................... 70

8.8 Systemic Administration of Fluorescent Compounds. ............................ 71

8.9 In Vivo Biodistribution Imaging. ........................................................ 71

8.10 Ex Vivo Fluorescence Microscopy, Pathology, and Immunofluorescence

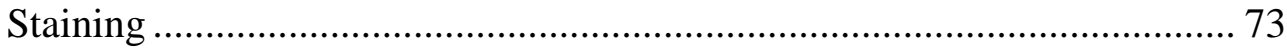

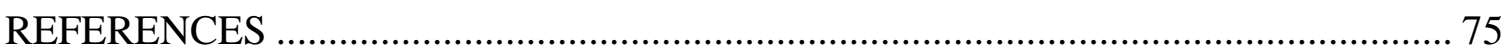

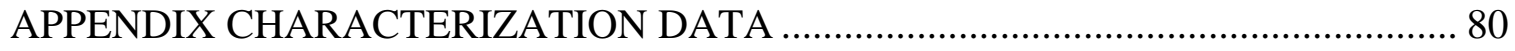




\section{LIST OF TABLES}

Table 3.1 Tabulated spectral properties of $\mathrm{pH}$-dependent $\mathbf{1}, \mathbf{3}, \mathbf{5}$ and $\mathbf{1 1}$ in acidic

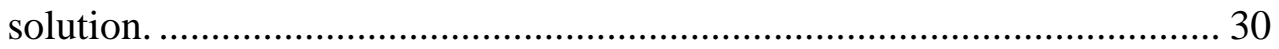

Table 3.2 Tabulated spectral properties of $\mathrm{pH}$-dependent $\mathbf{1}, \mathbf{3}, \mathbf{5}$ and $\mathbf{1 1}$ in basic

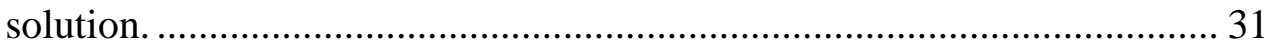

Table 3.3 Tabulated spectral properties of $\mathrm{pH}$-independent 2, 4, 6 and 12 in basic

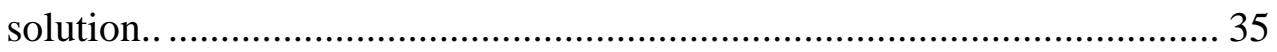

Table 3.3 Tabulated spectral properties of $\mathrm{pH}$-independent 2, 4, $\mathbf{6}$ and $\mathbf{1 2}$ in basic solution.

Table 3.5 Tabulated spectral properties of the conjugate acids of $\mathbf{7}$ and $\mathbf{8}$ in acidic

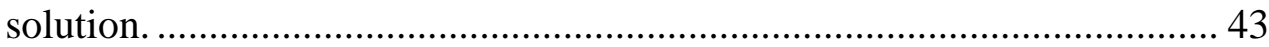

Table 3.6 Tabulated spectral properties of $\mathbf{7}$ and $\mathbf{8}$ in basic solution...................... 45 


\section{LIST OF FIGURES}

Figure $1.1 \quad 1$-substituted benzo[c]xanthene library. .................................................. 3

Figure 1.2 Energy levels and depiction of frontier molecular orbitals (HOMO and LUMO), calculated absorption spectra and physicochemical properties of

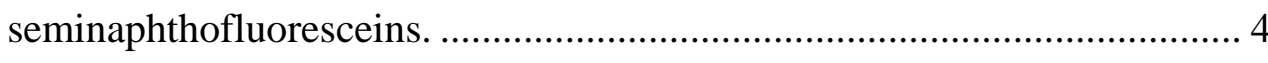

Figure 1.3 Energy levels and depiction of frontier molecular orbitals (HOMO and LUMO), calculated absorption spectra and physicochemical properties of seminaphthorhodamines............................................................................. 4

Figure 1.4 Energy levels and depiction of frontier molecular orbitals (HOMO and LUMO), calculated absorption spectra and physicochemical properties of seminaphthorhodafluors............................................................................. 5

Figure 3.1 Absorption spectra (solid lines) and normalized fluorescence emission spectra (dash lines) of $\mathrm{pH}$-dependent $\mathbf{1}, \mathbf{3}, \mathbf{5}$ and $\mathbf{1 1}$ in acidic solution ( $\mathrm{pH}$ $1.9, \mathrm{HCl})$.

Figure 3.2 Excitation Emission Matrices, of pH-dependent 1 (a), 3 (b), 5 (c) and 11 (d) in acidic solution.

Figure 3.3 Absorption spectra (solid lines) and normalized fluorescence emission spectra (dash lines) of $\mathrm{pH}$-dependent $\mathbf{1}, \mathbf{3}, \mathbf{5}$ and $\mathbf{1 1}$ in basic solution ( $\mathrm{pH}$ $12.1, \mathrm{NaOH})$.

Figure 3.4 Excitation Emission Matrices, of pH-dependent 1 (a), 3 (b), 5 (c) and 11 (d) in basic solution. 31

Figure 3.5 Absorption spectra as a function of $\mathrm{pH}$ for $\mathrm{pH}$-dependent $\mathbf{1}$ (a), $\mathbf{3}$ (b), $\mathbf{5}$ (c) and $\mathbf{1 1}(\mathrm{d})$

Figure 3.6 Absorption spectra of $\mathbf{1}, \mathbf{3}, \mathbf{5}$ and $\mathbf{1 1}$ as a function of solvents including $\mathrm{MeOH}$ and DMSO 
Figure 3.7 Absorption spectra (solid lines) and normalized fluorescence emission spectra (dash lines) of pH-independent 2, 4, 6 and $\mathbf{1 2}$ in pH 7.4 buffer. ... 34

Figure 3.8 Excitation Emission Matrices of pH-independent 2 (a), 4 (b), 6 (c) and 12 (d) in $\mathrm{pH} 7.4$ buffer. 35

Figure 3.9 Absorption spectra as a function of $\mathrm{pH}$ for methyl ether derivatives 2 (a), 4 (b), 6 (c) and 12 (d). 36

Figure 3.10 Absorption spectra as a function of solvents including DMSO, $\mathrm{MeOH}$ and pH 7.4 phosphate buffer for methyl ether derivatives 2 (a), 4 (b), 6 (c) and $12(d)$. 37

Figure 3.11 Absorption spectra (solid lines) and normalized fluorescence emission spectra (dash lines) of pH-independent $\mathbf{9 , 1 0}$ and $\mathbf{1 3}$ in $\mathrm{pH} 7.4$ buffer. ..... 38

Figure 3.12 Excitation Emission Matrices of pH-independent 9 (a), 10 (b), and 13 (c) in pH 7.4 buffer. 38

Figure 3.13 Absorption spectra as a function of $\mathrm{pH}$-independent seminaphthorhodamines 9 (a), 10 (b) and 13 (c). 40

Figure 3.14 Absorption spectra as a function of solvents including DMSO, $\mathrm{MeOH}$ and pH 7.4 phosphate buffer for $\mathrm{pH}$-independent seminaphthorhodamines 9 (a), 10 (b) and 13 (c). 41

Figure 3.15 Absorption spectra (solid lines) and normalized fluorescence emission spectra (dash lines) of conjugate acids of $\mathbf{7}$ and $\mathbf{8}$ in acidic solution ( $\mathrm{pH}$ 1.9, $\mathrm{HCl})$ 42

Figure 3.16 Excitation Emission Matrices of conjugate acids of 7 (a), and 8 (b) in acidic solution $(\mathrm{pH} 1.9, \mathrm{HCl})$. 43

Figure 3.17 Absorption spectra (solid lines) and normalized fluorescence emission spectra (dash lines) of $\mathbf{7}$ and $\mathbf{8}$ in basic solution ( $\mathrm{pH}$ 12.1, $\mathrm{NaOH}$ ) 44

Figure 3.18 Excitation Emission Matrices of 7 (a), and 8 (b) in basic solution (pH 12.1, $\mathrm{NaOH}$ ). 44 
Figure 4.1 Structures and calculated physicochemical properties summary of $\mathbf{2 , 1 2}$ and 13. 46

Figure 4.2 Cell viability of compounds $\mathbf{2 , 1 2}$, and $\mathbf{1 3}$ in Capan-1 cells...................... 47

Figure 4.3 Cellular uptake of compounds $\mathbf{2 , 1 2}$, and $\mathbf{1 3}$ in Capan- 1 cells.................. 48

Figure 4.4 Subcellular localization of compounds $\mathbf{2}$ in Capan-1 cells. Fluorescence images containing synthesized fluorophores are labeled as $\mathbf{2}$ (red).

Figure 4.5 Subcellular localization of compounds 12 in Capan-1 cells. Fluorescence images containing synthesized fluorophores are labeled as $\mathbf{1 2}$ (red)......... 50

Figure 4.6 Subcellular localization of compounds $\mathbf{1 3}$ in Capan-1 cells. Fluorescence images containing synthesized fluorophores are labeled as $\mathbf{1 3}$ (red)......... 51

Figure 5.1 Representative real time intraoperative fluorescence imaging of compound

2, 12, 13 and $\mathrm{MB}$ 53

Figure 5.2 In vivo organ biodistribution kinetics of synthesized compounds vs. methylene blue normalized fluorescence intensity. 55

Figure 5.3 Ex vivo resected organ normalized fluorescence intensity comparison of compounds $\mathbf{2}, \mathbf{1 2}$ and $\mathbf{1 3}$. 56

Figure 6.1 Ex vivo microscopy images of control and PDAC tissue slides stained with compound 12 . 58

Figure 6.2 Real time intraoperative fluorescence imaging of PDAC tumor bearing

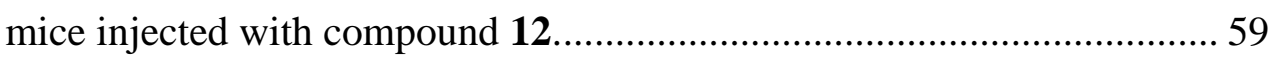

Figure 6.3 Biodistribution of compound 12 in PDAC mice........................................ 60

Figure 6.4 Ex vivo pathology of resected PDAC tissue.................................................. 61

Figure 6.5 Ex vivo pathology of resected PDAC tissue from uninjected control mice. 62 


\section{LIST OF ABBREVIATIONS}

\begin{tabular}{|c|c|}
\hline $\mathrm{Ar}$ & Argon \\
\hline $\mathrm{B} 1$ & Bladder \\
\hline Capan-1 & A human pancreatic ductal adenocarcinoma cell line \\
\hline $\mathrm{CT}$ & Computed tomography \\
\hline DAPI & 4',6-diamidino-2-phenylindole \\
\hline DFT & Density Functional Theory \\
\hline DI & Deionized \\
\hline DMF & Dimethylformamide \\
\hline DMSO & Dimethyl sulfoxide \\
\hline EEMs & Excitation emission matrices \\
\hline ER & Endoplasmic reticulum \\
\hline EtOAc & Ethyl acetate \\
\hline ev & Electron volt \\
\hline FBS & Fetal bovine serum \\
\hline FDA & The Food and Drug Administration \\
\hline $\mathrm{H} \& \mathrm{E}$ & Hematoxylin and eosin \\
\hline $\mathrm{H}_{2} \mathrm{SO}_{4}$ & Sulfuric acid \\
\hline $\mathrm{HCl}$ & Hydrochloric acid \\
\hline HOAc & Acetic acid \\
\hline HOMO & Highest occupied molecular orbital \\
\hline HPLC & High-performance liquid chromatography \\
\hline HR ESI & High-resolution electrospray ionization \\
\hline $\mathrm{Hz}$ & Hertz \\
\hline IACUC & Institutional Animal Care and Use Committee \\
\hline $\mathrm{IC}_{50}$ & Half maximal inhibitory concentration \\
\hline ICG & Indocyanine green \\
\hline IF & Immunofluorescence \\
\hline In & Intestine \\
\hline
\end{tabular}




\begin{tabular}{ll}
$\mathrm{K}_{2} \mathrm{CO}_{3}$ & Potassium carbonate \\
$\mathrm{Ki}$ & Kidney \\
$\mathrm{Li}$ & Liver \\
Log D & Physicochemical partition coefficients \\
LUMO & Lowest unoccupied molecular orbital \\
$m / z$ & Mass to charge ratio \\
$\mathrm{MB}$ & Methylene blue \\
$\mathrm{MeOH}$ & Methanol \\
$\mathrm{Mito}$ & Mitochondria \\
$\mathrm{MRI}$ & Magnetic resonance imaging \\
$\mathrm{MS}$ & Mass spectrometry \\
$\mathrm{MW}$ & Molecular weight \\
$\mathrm{NaOH}$ & Sodium hydroxide \\
$\mathrm{NIR}$ & Near infrared \\
$\mathrm{NMR}$ & Nuclear magnetic resonance \\
$\mathrm{OCT}$ & Optimal cutting temperature \\
$\mathrm{OHSU}$ & Oregon Health and Science University \\
$\mathrm{Pa}$ & Pancreas \\
$\mathrm{PanIN}$ & Pancreatic intraepithelial neoplasia \\
$\mathrm{PBS}$ & Phosphate-buffered saline \\
$\mathrm{PC}$ & Pancreatic cancer \\
$\mathrm{PDAC}$ & Pancreatic ductal adenocarcinoma \\
$\mathrm{PFA}$ & Paraformaldehyde \\
$\mathrm{pK}$ a & The logarithmic acidity constant \\
ppm & One part per million \\
$\mathrm{PSU}$ & Portland State University \\
$\mathrm{RT}$ & Room temperature \\
$\mathrm{SBR}$ & Signal to background ratio \\
$\mathrm{S.D}$. & Standard deviation \\
$\mathrm{Sp}$ & Spleen \\
\hline
\end{tabular}


St

TFA

TLC

$\mathrm{UV}-\mathrm{Vis}$

$\lambda_{\max } \mathrm{abs}$

$\lambda_{\max } \mathrm{em}$

$\delta$
Stomach

Trifluoroacetic acid

Thin layer chromatography

Ultraviolet-visible

The wavelength of maximum absorption

The wavelength of maximum emission

Chemical shifts 


\section{CHAPTER 1. INTRODUCTION AND PROBE DESIGN}

Approximately 53,000 people will be diagnosed with pancreatic cancer (PC) in the US in 2016, and will have a post-diagnosis life expectancy of 5 to 7 months. ${ }^{1}$ Pancreatic cancer is projected to become the second leading cause of cancer-related death by $2030 .^{2}$ Pancreatic ductal adenocarcinoma (PDAC) is the most prevalent form of PC. Current screening for PDAC using techniques such as MRI and CT is relatively expensive and ineffective, as over half of all cases are diagnosed after metastasis has occurred, limiting treatment options. Surgical resection is the treatment of choice because chemotherapy and radiation therapy do not significantly improve life expectancy. ${ }^{3}$ Unfortunately, surgical resection is only possible in $15-20 \%$ of cases. ${ }^{4}$ Moreover, to date there is no intraoperative guidance to differentiate malignant pancreas from normal pancreatic tissues. PC and healthy tissue are currently distinguished through white light visualization and palpation in the operating room as well as by rapid frozen section analysis while the surgical resection is in progress. ${ }^{5}$ However, $75 \%$ of patients are left with residual disease from margins not assessed by frozen section analysis, false negative assessments, and microscopic metastases not detected at the time of surgery. ${ }^{6}$

\subsection{Fluorescence Image Guided Surgery for PDAC}

Fluorescence-guided surgery to aid in the precise visualization of malignant tissue and cancer margins cannot be used for PDAC because a targeted contrast agent for PC is not available. Commercially available fluorescent dyes, including the only FDA-approved fluorescent contrast agents, indocyanine green (ICG), methylene blue (MB) and 
fluorescein, exhibit non-specific fluorescence and largely act as blood pool agents. MB has previously been used to image insulinoma, a rare form of PC compared to PDAC, in a genetically modified mouse model. Although MB provided specificity for insulinoma, the signal-to-background ratio (SBR) was relatively low. ${ }^{7}$ In a clinical setting, both MB and ICG have been studied for intraoperative PC imaging. MB was used to identify a solitary fibrous tumor of the pancreas, an extremely rare non-adenocarcinoma pancreatic tumor. ${ }^{8}$ No clear tumor-to-pancreas contrast was observed in patients undergoing pancreaticoduodenectomy using ICG as a contrast agent. ${ }^{9}$ Because there is no PDACspecific contrast reagent in clinical trials or approved for clinical use, ${ }^{10-17}$ we have developed a library of systematically-modified xanthene fluorescent dyes with scaffold similarity to MB to contribute to the development of PDAC tumor-specific contrast agents.

\subsection{Probe Design for PDAC Imaging}

One of the main challenges in PDAC therapy is drug delivery, and is largely attributed to the hypovascular and fibrotic tumor microenvironment. ${ }^{18}$ Thus, in order to attain desirable PDAC-selective accumulation and SBR we have synthesized a focused library of systematically-modified 1-substituted benzo[c]xanthene fluorophores (Fig. 1.1) to begin to define factors modulating in vivo biodistribution ${ }^{19}$ such as probe size, lipophilicity, solubility and ionization state. ${ }^{20-23}$ To minimize the effects of autofluorescence, these compounds were designed to exhibit significant bathochromic shifts compared to traditional long wavelength 3-substitued benzo[c]xanthenes via the formal repositioning of polar groups. ${ }^{24-27}$ Herein, we report two fluorescent small molecule molecular probes (2 and 12) which distribute to normal pancreas following systemic administration. More importantly, molecular probe $\mathbf{1 2}$ shows selective uptake in 
genetically modified mouse models of PDAC tumor, in addition to targeting cancerous epithelial cells through accumulation in the mitochondria.

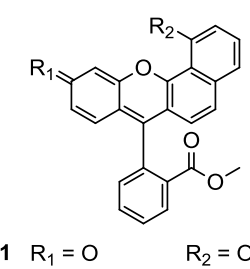

$1 \mathrm{R}_{1}=\mathrm{O}$

$3 \mathrm{R}_{1}={ }^{+} \mathrm{NH}$

$4 \mathrm{R}_{1}={ }^{+} \mathrm{NH}_{2}$

$5 \mathrm{R}_{1}={ }^{+} \mathrm{N}\left(\mathrm{CH}_{3}\right)_{2} \quad \mathrm{R}_{2}=\mathrm{OH}$

$6 \mathrm{R}_{1}={ }^{+} \mathrm{N}\left(\mathrm{CH}_{3}\right)_{2} \quad \mathrm{R}_{2}=\mathrm{OCH}_{3}$

$7 \mathrm{R}_{1}=\mathrm{O} \quad \mathrm{R}_{2}=\mathrm{NH}_{2}$

$8 \mathrm{R}_{1}=\mathrm{O} \quad \mathrm{R}_{2}=\mathrm{N}\left(\mathrm{CH}_{3}\right)_{2}$

$\begin{array}{ll}9 \mathrm{R}_{1}={ }^{+} \mathrm{NH}_{2} & \mathrm{R}_{2}=\mathrm{NH}_{2} \\ 10 \mathrm{R}_{1}={ }^{+} \mathrm{N}\left(\mathrm{CH}_{3}\right)_{2} & \mathrm{R}_{2}=\mathrm{NH}_{2}\end{array}$

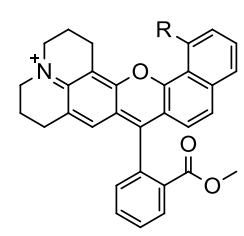

$11 \mathrm{R}=\mathrm{OH}$

$12 \mathrm{R}=\mathrm{OCH}_{3}$

$13 \mathrm{R}=\mathrm{NH}_{2}$

Figure 1.1 1-substituted benzo[c]xanthene library.

\subsection{Energy Levels and Depiction of Frontier Molecular Orbitals, Calculated}

Absorption Spectra and Physicochemical Properties 1-substituted Benzo[c]xanthene

\section{Library}

Compounds 1-13 (Fig. 1.1) were designed taking into account uptake and related "drug-like" properties that can be used as quantitative descriptors for predicting and optimizing biodistribution and tissue targeting. ${ }^{28}$ The predicted absorption spectra and physicochemical properties of 1-13 are shown in Fig. 1.2-1.4. In summary, predicted absorption spectra show peaks between 400 to $650 \mathrm{~nm}, \log \mathrm{D}$ values are within 0.5 and 5, molecular weights are between 400 and $500 \mathrm{~g} / \mathrm{mol}$, each compound has $0-4$ hydrogen bond donors and less than 10 hydrogen bond acceptors, and polar surface areas are all less than $140 \AA^{2}$, in keeping with requirements to be considered for tissue targeting according to the Lipinski $^{29}$ and Veber rules. ${ }^{30}$ 


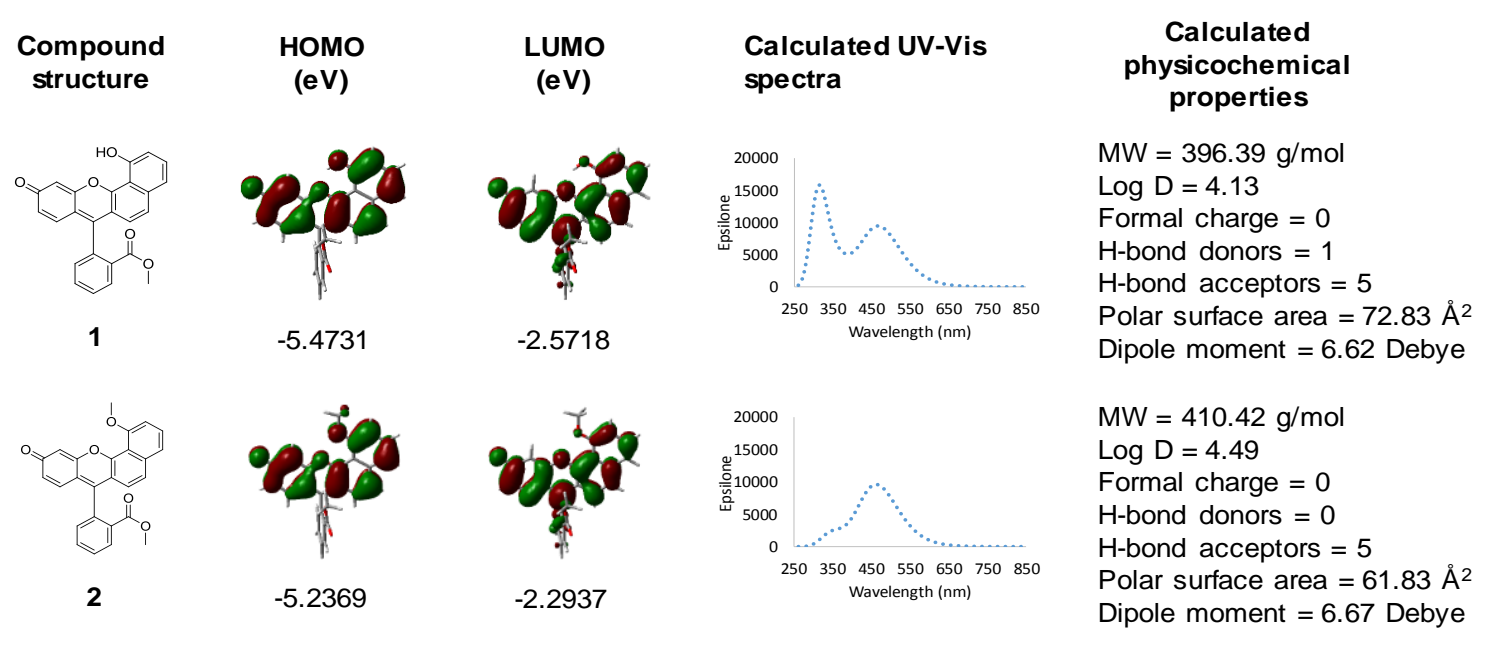

Figure 1.2 Energy levels and depiction of frontier molecular orbitals (HOMO and LUMO), calculated absorption spectra and physicochemical properties of seminaphthofluoresceins.

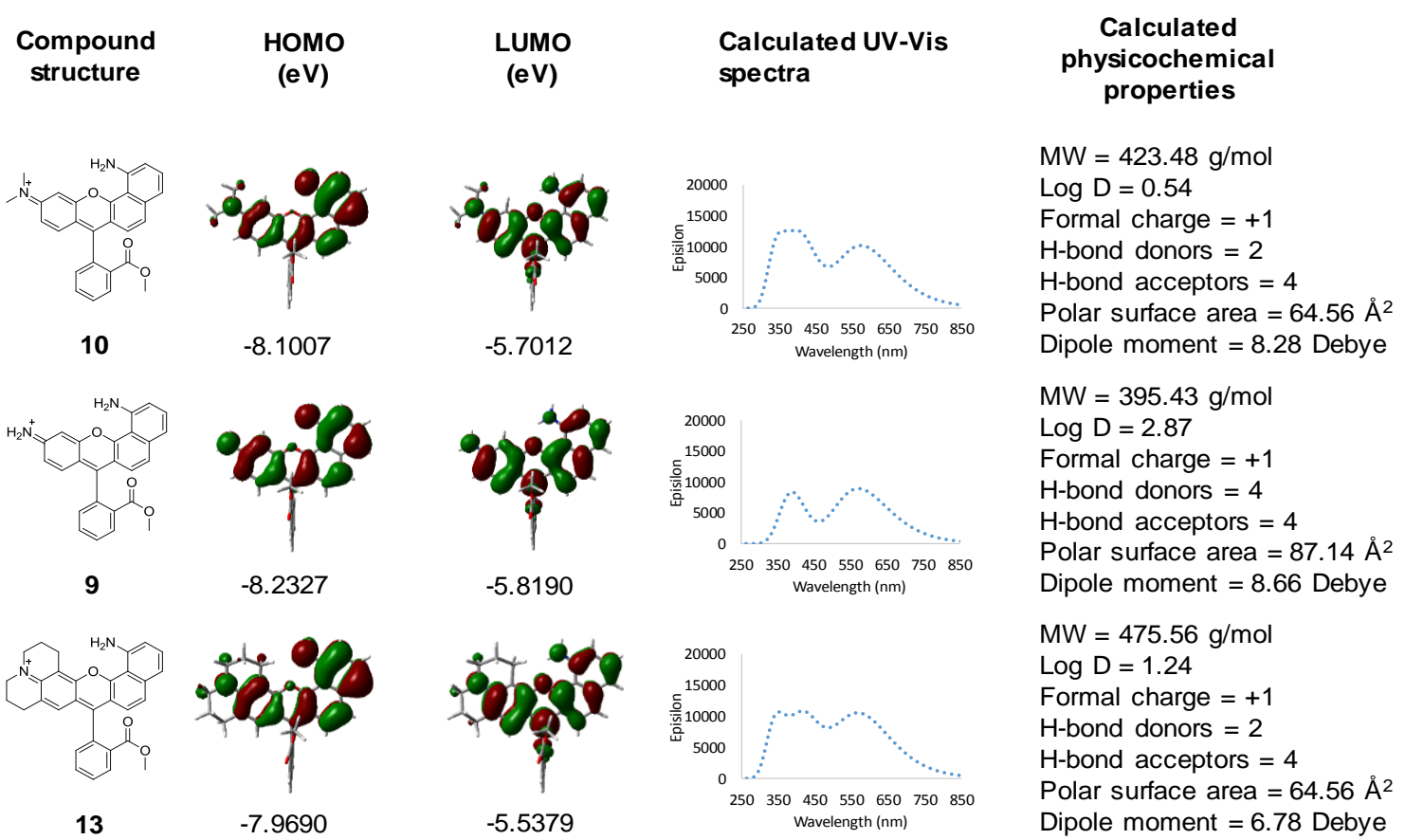

Figure 1.3 Energy levels and depiction of frontier molecular orbitals (HOMO and LUMO), calculated absorption spectra and physicochemical properties of seminaphthorhodamines. 

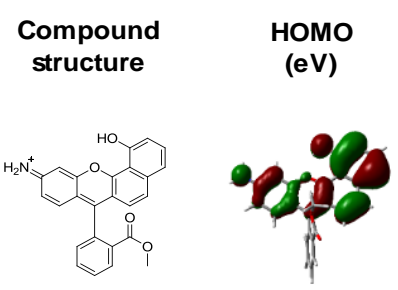

LUMO

(eV)

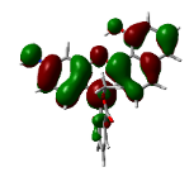

$-11.6086$
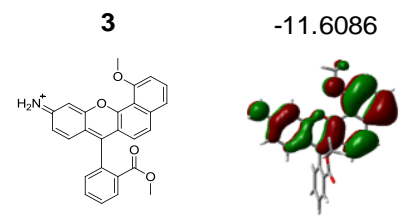

$-8.5473$
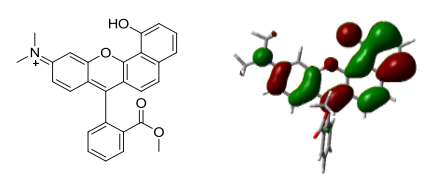

$-8.496$

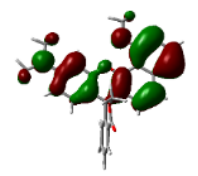

$-8.3824$

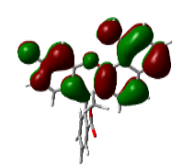

$-5.1447$

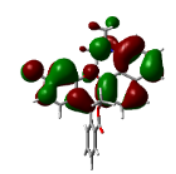

$-5.1613$

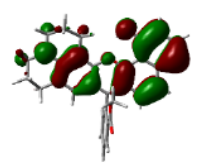

$-8.3043$

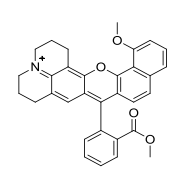

12

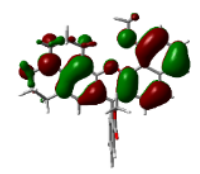

$-8.1848$

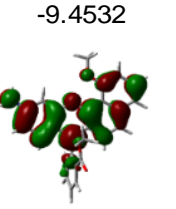

$-5.7926$

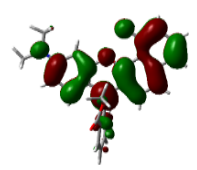

$-5.954$

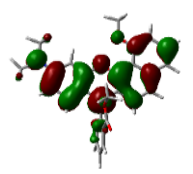

$-5.6702$

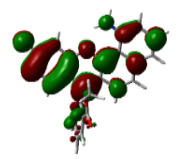

$-2.3650$

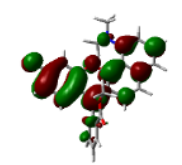

$-2.3103$

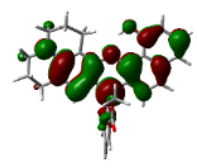

$-5.7513$

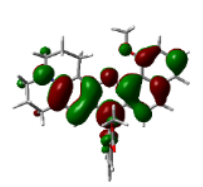

$-5.4889$
Calculated UV-Vis spectra

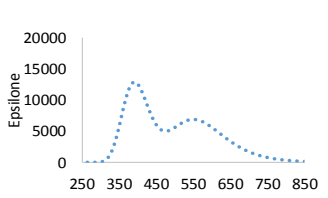

$450 \quad 550 \quad 650 \quad 750$
Wavelength $(\mathrm{nm})$

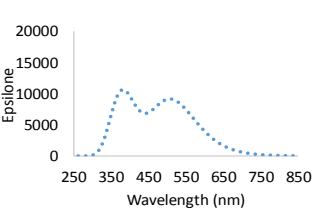

Wavelength (nm)

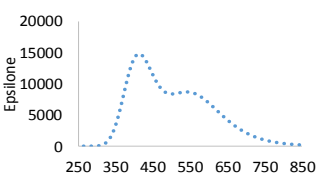

Wavelength (nm)
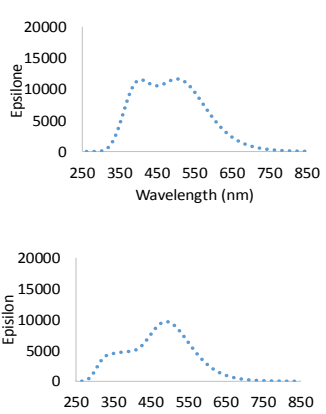

Wavelength (nm)

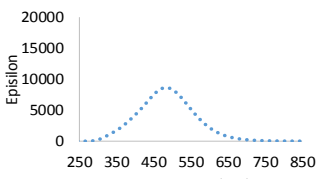

Wavelength $(\mathrm{nm})$
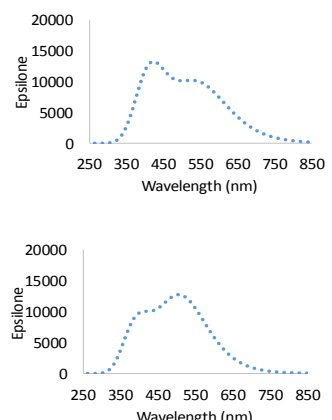

Wavelength (nm)
Calculated

physicochemical

properties

$\mathrm{MW}=396.41 \mathrm{~g} / \mathrm{mol}$

Log $D=3.87$

Formal charge $=+1$

$\mathrm{H}$-bond donors $=3$

$\mathrm{H}$-bond acceptors $=4$

Polar surface area $=81.35 \AA^{2}$

Dipole moment $=15.63$ Debye

$\mathrm{MW}=410.44 \mathrm{~g} / \mathrm{mo}$

$\log D=3.99$

Formal charge $=+1$

$\mathrm{H}$-bond donors $=2$

$\mathrm{H}$-bond acceptors $=4$

Polar surface area $=70.35 \AA^{2}$

Dipole moment $=7.96$ Debye

$\mathrm{MW}=424.47 \mathrm{~g} / \mathrm{mol}$

$\log \mathrm{D}=1.61$

Formal charge $=+1$

$\mathrm{H}$-bond donors $=1$

$\mathrm{H}$-bond acceptors $=4$

Polar surface area $=58.77 \AA^{2}$

Dipole moment $=6.97$ Debye

$\mathrm{MW}=438.49 \mathrm{~g} / \mathrm{mol}$

$\log \mathrm{D}=1.21$

Formal charge $=+1$

$\mathrm{H}$-bond donors $=0$

$\mathrm{H}$-bond acceptors $=4$

Polar surface area $=47.77 \AA^{2}$ Dipole moment $=7.59$ Debye

$\mathrm{MW}=395.41 \mathrm{~g} / \mathrm{mol}$

$\log \mathrm{D}=3.82$

Formal charge $=0$

$\mathrm{H}$-bond donors $=2$

$\mathrm{H}$-bond acceptors $=5$

Polar surface area $=78.62 \AA^{2}$

Dipole moment $=5.76$ Debye

$\mathrm{MW}=423.46 \mathrm{~g} / \mathrm{mol}$

$\log D=4.76$

Formal charge $=0$

$\mathrm{H}$-bond donors $=0$

$\mathrm{H}$-bond acceptors $=5$

Polar surface area $=55.84 \AA^{2}$

Dipole moment $=6.58$ Debye

$\mathrm{MW}=476.54 \mathrm{~g} / \mathrm{mol}$

$\log D=2.30$

Formal charge $=+1$

$\mathrm{H}$-bond donors $=1$

$\mathrm{H}$-bond acceptors $=4$

Polar surface area $=58.77 \AA^{2}$

Dipole moment $=5.95$ Debye

$\mathrm{MW}=490.57 \mathrm{~g} / \mathrm{mol}$

Log $D=1.91$

Formal charge $=+1$

$\mathrm{H}$-bond donors $=0$

$\mathrm{H}$-bond acceptors $=4$

Polar surface area $=47.77 \AA^{2}$

Dipole moment $=6.52$ Debye

Figure 1.4 Energy levels and depiction of frontier molecular orbitals (HOMO and LUMO), calculated absorption spectra and physicochemical properties of seminaphthorhodafluors. 


\section{CHAPTER 2. SYNTHESIS}

Unless otherwise indicated, all commercially available starting materials were used directly without further purification. Silica gel Sorbent Technologies 32-63 $\mu \mathrm{m}$ was used for flash column chromatography. ${ }^{1} \mathrm{H}$ - and ${ }^{13} \mathrm{C}$ NMR spectra were obtained on either a ARX-400 or ARX 600 Advance Bruker spectrometer. Chemical shifts ( $\delta$ ) are given in ppm relative to DMSO- $d_{6}\left(2.50 \mathrm{ppm},{ }^{1} \mathrm{H}, 39.52{ }^{13} \mathrm{C}\right)$ unless otherwise indicated. MS (HRMS, ESI) spectra were obtained at the PSU Bioanalytical Mass Spectrometry Facility on a ThermoElectron LTQ-Orbitrap high resolution mass spectrometer with a dedicated Accela HPLC system. Compounds $\mathbf{1}$ and $\mathbf{2}$ were synthesized as described in the literature. ${ }^{18}$

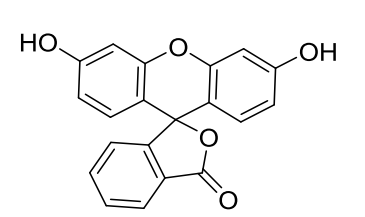

14

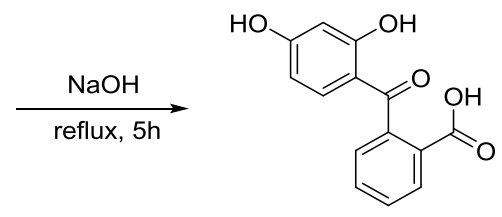

15

\subsection{Synthesis of 2-(2,4-dihydroxybenzoyl)benzoic acid, 15.}

$\mathrm{NaOH}(50 \mathrm{~g}, 1.25 \mathrm{~mol})$ is dissolved in $100 \mathrm{~mL}$ of DI water while cooling in an ice bath. Fluorescein (14) is added in one portion and the mixture is refluxed 5h. The mixture is cooled down to room temperature and neutralized to $\mathrm{pH} 7 \mathrm{using}$ concentrated $\mathrm{HCl}$. The mixture is treated with $2 \% \mathrm{NaHCO}_{3}$ to dissolve the solid formed, and then extracted with ethyl ether $(3 \times 100 \mathrm{~mL})$. The aqueous phase is acidified to $\mathrm{pH} 2$ using concentrated $\mathrm{HCl}$, then extracted with ethyl ether $(300 \mathrm{~mL})$. The ethyl ether is evaporated to leave a brown residue. The target compound $\mathbf{1 5}$ is isolated by recrystallization from water. Yield: $4.35 \mathrm{~g}$, 56\%. ${ }^{1} \mathrm{H}$ NMR (400 MHz, DMSO) $\delta 13.19$ (s, 1H), 12.24 (s, 1H), 10.71 (s, 1H), 8.00 (dd, 
$J=7.7,0.9 \mathrm{~Hz}, 1 \mathrm{H}), 7.74-7.67(\mathrm{~m}, 1 \mathrm{H}), 7.65-7.61(\mathrm{~m}, 1 \mathrm{H}), 7.42(\mathrm{dd}, J=7.5,1.0 \mathrm{~Hz}, 1 \mathrm{H})$, $6.95-6.90(\mathrm{~m}, 1 \mathrm{H}), 6.33(\mathrm{~d}, J=2.3 \mathrm{~Hz}, 1 \mathrm{H}), 6.29(\mathrm{dd}, J=8.7,2.3 \mathrm{~Hz}, 1 \mathrm{H}) .{ }^{13} \mathrm{C} \mathrm{NMR}$ (101 MHz, DMSO) $\delta$ 200.51, 166.76, 165.01, 164.42, 140.00, 134.75, 132.32, 129.99, $129.74,129.48,127.45,113.29,108.34,102.55$. HR ESI $[M+H]^{+} \mathrm{m} / z$ 259.0602, calc. for $\mathrm{C}_{14} \mathrm{H}_{11} \mathrm{O}_{5} 259.0600$.

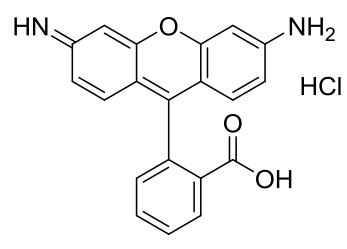

16

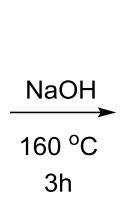

h

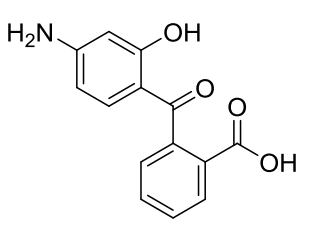

17

\subsection{Synthesis of 2-(4-amino-2-hydroxybenzoyl)benzoic acid, 17.}

Rhodamine 110 hydrochloride (16) $(0.2 \mathrm{~g}, 0.545 \mathrm{mmol})$ is mixed with $\mathrm{NaOH}$ $(0.375 \mathrm{~g}, 9.27 \mathrm{mmol})$ and $180 \mu \mathrm{L}$ of water. The mixture is stirred and heated at $160{ }^{\circ} \mathrm{C}$ for $2 \mathrm{~h}, 0.5 \mathrm{~mL}$ of $50 \% \mathrm{NaOH}$ is added in one portion and the mixture heated and stirred at $160{ }^{\circ} \mathrm{C}$ for an additional $1 \mathrm{~h}$. The mixture is allowed to cool down to room temperature and diluted with $10 \mathrm{~mL}$ of water. The mixture is acidified to $\mathrm{pH} 1$ with concentrated $\mathrm{HCl}$. The resulting mixture is extracted with ethyl ether $(2 \times 50 \mathrm{~mL})$, the organic extracts are combined, dried over anhydrous $\mathrm{Na}_{2} \mathrm{SO}_{4}$, filtered and the solvent evaporated under vacuum to leave 17 as a pale yellow solid. Yield: $0.130 \mathrm{~g}, 93 \% .{ }^{1} \mathrm{H}$ NMR (400 MHz, DMSO) $\delta$ $13.01(\mathrm{~s}, 1 \mathrm{H}), 12.59$ (s, 1H), $7.95(\mathrm{dd}, J=7.7,1.0 \mathrm{~Hz}, 1 \mathrm{H}), 7.67$ (td, $J=7.5,1.4 \mathrm{~Hz}, 1 \mathrm{H})$, $7.60(\operatorname{td}, J=7.6,1.4 \mathrm{~Hz}, 1 \mathrm{H}), 7.36(\mathrm{dd}, J=7.5,1.0 \mathrm{~Hz}, 1 \mathrm{H}), 6.71(\mathrm{~d}, J=8.6 \mathrm{~Hz}, 1 \mathrm{H}), 6.44$ (s, 2H), $6.05-5.97(\mathrm{~m}, 2 \mathrm{H}) .{ }^{13} \mathrm{C}$ NMR (101 MHz, DMSO) $\delta$ 198.31, 166.92, 164.98, $156.82,140.07,134.48,131.95,129.84,129.69,129.31,127.68,109.79,106.48,98.16$. 
HR ESI $[\mathrm{M}+\mathrm{H}]^{+} m / z$ 258.0754, calc for $\mathrm{C}_{14} \mathrm{H}_{12} \mathrm{NO}_{4}$ 258.0760; HR ESI $[\mathrm{M}+\mathrm{Na}]^{+} m / z$ 280.0575, calc. for $\mathrm{C}_{14} \mathrm{H}_{11} \mathrm{NO}_{4} \mathrm{Na}^{+} 280.0580$.

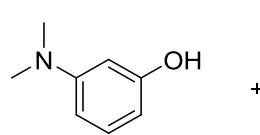

18

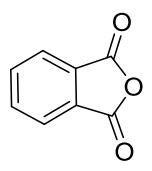

19

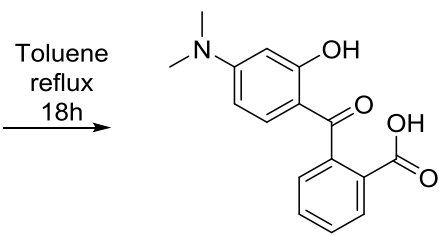

20

\subsection{Synthesis of 2-(4-(dimethylamino)-2-hydroxybenzoyl)benzoic acid, 20.}

3-dimethyl amino phenol (18) (5 g, $36.44 \mathrm{mmol})$ and phthalic anhydride (19) (5.39 $\mathrm{g}, 36.44 \mathrm{mmol}$ ) are dissolved in $150 \mathrm{~mL}$ of toluene and refluxed $18 \mathrm{~h}$. The solvent is evaporated under vacuum to leave a purple residue. The residue is dissolved in ethyl acetate and the mixture passed through a plug of silica gel using EtOAc:Hexanes 1:1, EtOAc:Hexanes 3:1, and EtOAc for elution; $4.32 \mathrm{~g}, 42 \%$ of $\mathbf{2 0}$ are obtained. ${ }^{1} \mathrm{H}$ NMR (400 $\left.\mathrm{MHz}, \mathrm{CDCl}_{3}\right) \delta 12.51(\mathrm{~s}, 1 \mathrm{H}), 8.09(\mathrm{dd}, J=7.9,0.9 \mathrm{~Hz}, 1 \mathrm{H}), 7.66-7.59(\mathrm{~m}, 1 \mathrm{H}), 7.53(\mathrm{td}$, $J=7.7,1.3 \mathrm{~Hz}, 1 \mathrm{H}), 7.35(\mathrm{dd}, J=7.5,0.9 \mathrm{~Hz}, 1 \mathrm{H}), 6.88(\mathrm{~d}, J=9.1 \mathrm{~Hz}, 1 \mathrm{H}), 6.15(\mathrm{~d}, J=$ $2.5 \mathrm{~Hz}, 1 \mathrm{H}), 6.06(\mathrm{dd}, J=9.1,2.5 \mathrm{~Hz}, 1 \mathrm{H}), 3.02(\mathrm{~s}, 6 \mathrm{H}) .{ }^{13} \mathrm{C} \mathrm{NMR}\left(101 \mathrm{MHz}, \mathrm{CDCl}_{3}\right) \delta$ $198.78,170.69,165.29,156.10,141.35,134.44,132.96,131.23,129.34,128.15,127.81$, 110.45, 104.13, 97.89, 40.09. HR ESI $[\mathrm{M}+\mathrm{H}]^{+} m / z$ 286.1094, calc for $\mathrm{C}_{16} \mathrm{H}_{16} \mathrm{NO}_{4}$ 286.1073; HR ESI $[\mathrm{M}+\mathrm{Na}]^{+} m / z$ 308.0915, calc. for $\mathrm{C}_{16} \mathrm{H}_{15} \mathrm{NO}_{4} \mathrm{Na}^{+} 308.0893$.

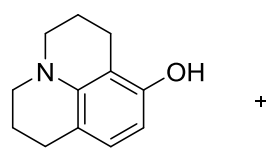

21

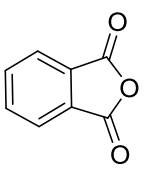

19

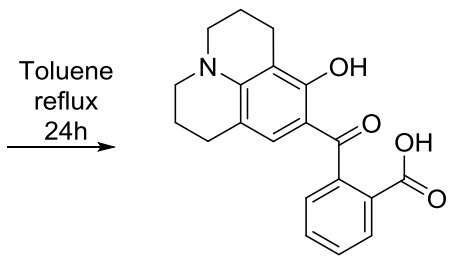

22 


\subsection{Synthesis of 2-(8-hydroxy-2,3,6,7-tetrahydro-1H,5H-pyrido[3,2,1-}

\section{ij]quinoline-9-carbonyl)benzoic acid, 22.}

Phthalic anhydride (19) (0.392 g 2.64 mmol) and 8-hydroxyjulolidine (21) (0.5 g, $2.64 \mathrm{mmol}$ ) are dissolved in $12 \mathrm{~mL}$ of toluene. The mixture is refluxed $24 \mathrm{~h}$, then the solvent evaporated under vacuum. The target compound $\mathbf{2 2}$ is isolated as a pale yellow solid by flash column chromatography on silica gel using $\mathrm{CH}_{2} \mathrm{Cl}_{2}: \mathrm{MeOH}$ 95:5 for elution. Yield: $622 \mathrm{mg}, 70 \% .{ }^{1} \mathrm{H}$ NMR (400 MHz, DMSO) $\delta 13.02$ (s, 1H), 12.94 (s, 1H), 7.97 $7.91(\mathrm{~m}, 1 \mathrm{H}), 7.65(\mathrm{dt}, J=7.5,3.8 \mathrm{~Hz}, 1 \mathrm{H}), 7.59(\mathrm{dt}, J=7.6,3.8 \mathrm{~Hz}, 1 \mathrm{H}), 7.33(\mathrm{~d}, J=6.5$ $\mathrm{Hz}, 1 \mathrm{H}), 6.39(\mathrm{~s}, 1 \mathrm{H}), 3.24(\mathrm{dd}, J=11.6,7.0 \mathrm{~Hz}, 4 \mathrm{H}), 2.59(\mathrm{t}, J=6.4 \mathrm{~Hz}, 2 \mathrm{H}), 2.41(\mathrm{t}, J=$ $6.1 \mathrm{~Hz}, 2 \mathrm{H}), 1.90-1.80(\mathrm{~m}, 2 \mathrm{H}), 1.81-1.70(\mathrm{~m}, 2 \mathrm{H}) .{ }^{13} \mathrm{C}$ NMR (101 MHz, DMSO) $\delta$ $197.98,167.04,159.77,148.79,140.16,131.76,129.85,129.66,129.19,127.70,112.43$, 108.38, 104.61, 54.91, 49.39, 48.94, 26.66, 21.09, 20.09, 19.57. HR ESI $[\mathrm{M}+\mathrm{H}]^{+} \mathrm{m} / z$ 338.1379, calc. for $\mathrm{C}_{20} \mathrm{H}_{20} \mathrm{NO}_{4}$ 338.1386; HR ESI $[\mathrm{M}+\mathrm{Na}]^{+} \mathrm{m} / z$ 360.1197, calc. for $\mathrm{C}_{20} \mathrm{H}_{19} \mathrm{NO}_{4} \mathrm{Na}^{+} 360.1206$.

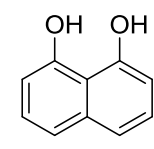

23

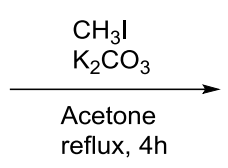

reflux, $4 \mathrm{~h}$

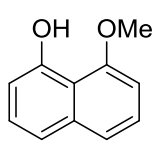

24

\subsection{Synthesis of 8-methoxynaphthalen-1-ol, 24.}

Under Ar atmosphere 1,8-dihydroxynaphthalene (23) (1 g, $6.24 \mathrm{mmol})$ and ground $\mathrm{K}_{2} \mathrm{CO}_{3}$ are suspended in $5 \mathrm{~mL}$ of acetone, $\mathrm{CH}_{3} \mathrm{I}(0.88 \mathrm{~g}, 6.24 \mathrm{mmol})$ is added in one portion. The mixture is refluxed for $4 \mathrm{~h}$. The mixture is allowed to cool down to room temperature, diluted with $15 \mathrm{~mL}$ of DI water and then acidified to $\mathrm{pH} 1$ using $6 \mathrm{M} \mathrm{HCl}$. The aqueous phase is extracted with ethyl acetate $(2 \times 50 \mathrm{~mL})$. The organic extracts are combined, dried 
over anhydrous $\mathrm{Na}_{2} \mathrm{SO}_{4}$, filtered and the solvent evaporated under vacuum. The target compound $\mathbf{2 4}$ is isolated by flash column chromatography on silica gel using EtOAc:Hexanes 25:75 for elution. Yield: $0.86 \mathrm{~g}, 79 \% .{ }^{1} \mathrm{H}$ NMR (400 MHz, DMSO) $\delta 9.38$ (s, 1H), $7.45-7.28(\mathrm{~m}, 4 \mathrm{H}), 6.93(\mathrm{dd}, J=7.6,0.9 \mathrm{~Hz}, 1 \mathrm{H}), 6.78(\mathrm{dd}, J=6.6,2.1 \mathrm{~Hz}, 1 \mathrm{H})$, $4.02(\mathrm{~d}, J=5.3 \mathrm{~Hz}, 3 \mathrm{H}) .{ }^{13} \mathrm{C}$ NMR $(101 \mathrm{MHz}, \mathrm{DMSO}) \delta 155.89,154.00,136.32,127.46$, $126.17,120.95,118.49,114.56,110.05,104.44,56.16,40.12$.

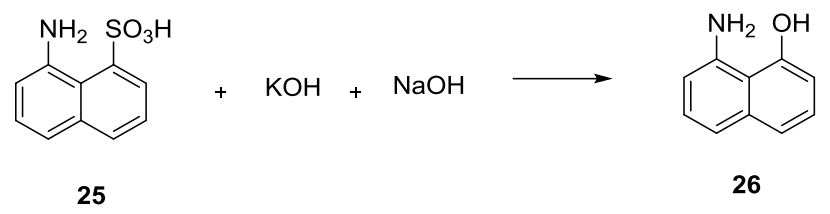

\subsection{Synthesis of 8-aminonaphthalen-1-ol, 26.}

Aminonaphthalene sulfonic acid (25) $(12.5 \mathrm{~g}, 56 \mathrm{mmol})$ is made into a paste with $15 \mathrm{~mL}$ of water. $\mathrm{KOH}(22.3 \mathrm{~g}, 397 \mathrm{mmol})$ and $\mathrm{NaOH}(22.39 \mathrm{~g}, 560 \mathrm{mmol})$ are melted at $200{ }^{\circ} \mathrm{C}$ in a stainless steel beaker while being stirred using a mechanical stirrer $(320 \mathrm{rpm})$. The aminonaphthalene sulfonic acid paste is added portion wise. The temperature is increased slowly to $260{ }^{\circ} \mathrm{C}$ while stirred. When the temperature reaches $260{ }^{\circ} \mathrm{C}$, the mixture turns dark brown, then it liquefies and the thick melt turns black giving off white fumes. The mixture is kept for additional $15 \mathrm{~min}$ at this temperature. The mixture is cooled rapidly to avoid further oxidation. The solidified cake is dissolved in $500 \mathrm{~mL}$ of DI water, and filtered. The filtrate is acidified with concentrated $\mathrm{HCl}$ to $\mathrm{pH} 1$ and filtered again. The filtrate is neutralized by adding solid $\mathrm{NaHCO}_{3}$ portion wise. The precipitate formed is filtered, washed with water $(300 \mathrm{~mL})$ and dried under vacuum. $5.3 \mathrm{~g}(59 \%)$ of 26 are obtained. ${ }^{1} \mathrm{H}$ NMR (600 MHz, DMSO) $\delta 7.11-7.03(\mathrm{~m}, 3 \mathrm{H}), 6.86(\mathrm{dd}, J=8.0,1.1 \mathrm{~Hz}$, $1 \mathrm{H}), 6.61(\mathrm{dd}, J=5.0,3.6 \mathrm{~Hz}, 1 \mathrm{H}), 6.45(\mathrm{dd}, J=7.5,1.1 \mathrm{~Hz}, 1 \mathrm{H}) .{ }^{13} \mathrm{C} \mathrm{NMR}(101 \mathrm{MHz}$, 
DMSO) $\delta 155.37,146.33,137.19,126.93,125.78,118.89,114.39,113.84,107.33,107.22$.

HR ESI $[\mathrm{M}+\mathrm{H}]^{+} \mathrm{m} / 2$ 160.0753, calc. for $\mathrm{C}_{10} \mathrm{H}_{10} \mathrm{NO} 160.0756$.

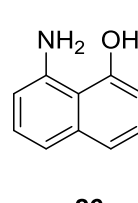

26

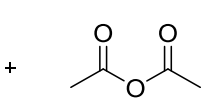

27

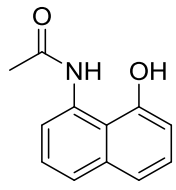

28

\subsection{Synthesis of N-(8-hydroxynaphthalen-1-yl)acetamide, 28.}

8-amino-1-naphthol (26) $(5 \mathrm{~g}, 31 \mathrm{mmol})$ is suspended in $100 \mathrm{~mL}$ of DI water. $6 \mathrm{~N}$ $\mathrm{HCl}$ is added until a homogeneous solution is obtained, the mixture is sonicated to help to dissolve the solid. A yellow-black solution is obtained at $\mathrm{pH}$ around 1. Acetic anhydride ( $4.81 \mathrm{~g}, 47.12 \mathrm{mmol})$ is added in one portion and the mixture stirred at room temperature, after a few seconds a precipitate starts forming. Solid $\mathrm{NaHCO}_{3}$ is added portion wise until pH 6-7 is reached. A cream precipitate is obtained. The precipitate is filtered and washed with water and dissolved in a minimum amount of ethanol. The solution is brought to boil and then activated carbon is added, the mixture is boiled for additional $3 \mathrm{~min}$, then filtered and washed with cold ethanol. DI water is added to the filtrate until a turbid solution is obtained, after 30 min upon standing, the target compound precipitates as small yellow needles. The recrystallized product is filtered, washed with water and then dried under vacuum. $2.05 \mathrm{~g}$, (33\%) of $\mathbf{2 8}$ are obtained. ${ }^{1} \mathrm{H}$ NMR (400 MHz, DMSO) $\delta 11.23(\mathrm{~s}, 1 \mathrm{H})$, $11.08(\mathrm{~s}, 1 \mathrm{H}), 8.41(\mathrm{~d}, J=7.6 \mathrm{~Hz}, 1 \mathrm{H}), 7.49(\mathrm{dd}, J=8.2,1.0 \mathrm{~Hz}, 1 \mathrm{H}), 7.35(\mathrm{ddd}, J=8.2$, 6.4, $2.8 \mathrm{~Hz}, 2 \mathrm{H}), 6.89(\mathrm{dd}, J=7.4,1.3 \mathrm{~Hz}, 1 \mathrm{H}), 2.15$ (s, 3H). ${ }^{13} \mathrm{C}$ NMR (101 MHz, DMSO) $\delta 167.67,153.34,136.17,135.60,126.29,126.05,122.87,119.94,115.10,114.67,110.12$, 
25.29. HR ESI $[\mathrm{M}+\mathrm{H}]^{+} \mathrm{m} / z$ 202.0856, calc. for $\mathrm{C}_{12} \mathrm{H}_{11} \mathrm{NO}_{2}$ 202.8202; $[\mathrm{M}+\mathrm{Na}]^{+} \mathrm{m} / z$ 224.0675, calc. for $\mathrm{C}_{12} \mathrm{H}_{10} \mathrm{NO}_{2} \mathrm{Na} 224.0675$.

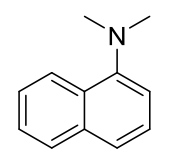

29

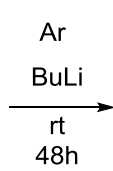

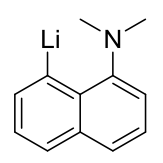

30

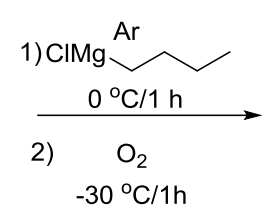

3) $\mathrm{Zn}, 10 \% \mathrm{HOAc}$

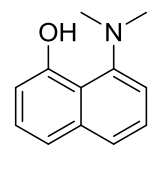

31

\subsection{Synthesis of 8-(dimethylamino)naphthalen-1-ol, 31 .}

Under Ar atm, 1.7 M $n$-butyl lithium in hexanes $(4.71 \mathrm{~g}, 73.6 \mathrm{mmol})$ is added in a continuous stream to a stirred solution of $N, N$-dimethyl-1-naphthylamine (29) (2.74 g, 16 $\mathrm{mmol}$ ) in $35 \mathrm{~mL}$ of anhydrous ether. The mixture is stirred $48 \mathrm{~h}$ at room temperature. The lithiated naphthylamine (30) solution is cooled down to $0{ }^{\circ} \mathrm{C}$ and $2 \mathrm{M} n$-butyl magnesium chloride in hexanes $(7.93 \mathrm{~g}, 67.9 \mathrm{mmol})$ is added slowly in order to keep the temperature at $0{ }^{\circ} \mathrm{C}$. After $20 \mathrm{~min}$, the reaction mixture is cooled down to $-30{ }^{\circ} \mathrm{C}$ and maintained at this temperature for $4 \mathrm{~h}$ while dry $\mathrm{O}_{2}$ is passed through the solution with stirring. A light yellowgrey precipitate forms and the mixture cannot be longer stirred. A solution of $10 \%$ acetic acid in water $(100 \mathrm{~mL})$ is added under Ar atm, followed by the addition of $\mathrm{Zn}$ powder (1 g). The two phases are stirred for 30 min until effervescence had ceased and the aqueous phase is neutral. The flocculated $\mathrm{Zn}$ is filtered and the phases separated. The organic phase is washed with saturated $\mathrm{NaHCO}_{3}$ solution $(3 \times 50 \mathrm{~mL})$, water $(1 \times 50 \mathrm{~mL})$, dried over anhydrous $\mathrm{Na}_{2} \mathrm{SO}_{4}$ and the solvent evaporated under vacuum. The target compound $\mathbf{3 1}$ is isolated by flash column chromatography on silica gel using $20 \%$ ether in hexanes, after pre-absorbing the crude mixture onto silica. Yield: $1.5 \mathrm{~g}, 50 \%$. ${ }^{1} \mathrm{H}$ NMR $\left(400 \mathrm{MHz}, \mathrm{CDCl}_{3}\right)$ $\delta 14.36(\mathrm{~s}, 1 \mathrm{H}), 7.66(\mathrm{dd}, J=8.0,1.2 \mathrm{~Hz}, 1 \mathrm{H}), 7.41-7.26(\mathrm{~m}, 4 \mathrm{H}), 6.85(\mathrm{dd}, J=7.5,1.2$ $\mathrm{Hz}, 1 \mathrm{H}), 2.84(\mathrm{~s}, 6 \mathrm{H}) .{ }^{13} \mathrm{C} \mathrm{NMR}\left(101 \mathrm{MHz}, \mathrm{CDCl}_{3}\right) \delta 156.91,150.08,136.40,127.75$, 
126.80, 125.69, 119.06, 118.05, 116.87, 110.05, 46.47. HR ESI $[\mathrm{M}+\mathrm{H}]^{+} \mathrm{m} / z$ 188.1072, calc. for $\mathrm{C}_{12} \mathrm{H}_{14} \mathrm{NO} 188.1069$.

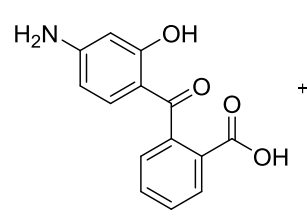

17

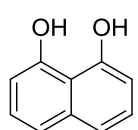

23

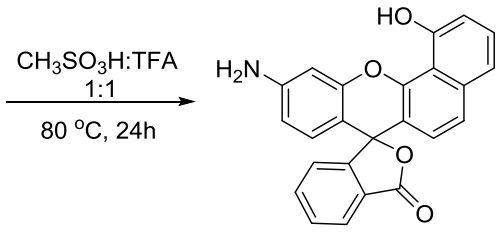

32
$\mathrm{MeOH}$ $\underset{50^{\circ} \mathrm{Cl}, 72 \mathrm{~h}}{\stackrel{\mathrm{OCCl}}{\longrightarrow}}$

$50^{\circ} \mathrm{C}, 72 \mathrm{~h}$

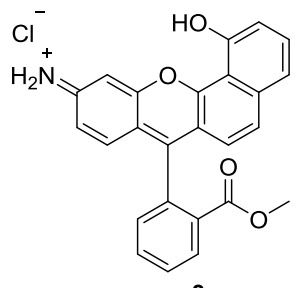

3

\subsection{Synthesis of 1-hydroxy-7-(2-(methoxycarbonyl)phenyl)-10H-}

\section{benzo[c]xanthen-10-iminium chloride, 3 .}

Compound 17 (100 mg, $0.388 \mathrm{mmol}$ ) and 1,8-dihydroxynaphthalene (23) (93.4 mg, $0.583 \mathrm{mmol}$ ) are dissolved in $1.5 \mathrm{~mL}$ of methanesulfonic acid. $1.5 \mathrm{~mL}$ of TFA is added and the mixture heated at $80{ }^{\circ} \mathrm{C}$ for $24 \mathrm{~h}$. The mixture is allowed to cool down to room temperature and then poured into $20 \mathrm{~mL}$ of DI water. The precipitate formed is filtered and washed with water until the filtrate is neutral. The title compound is isolated by flash column chromatography on silica gel using $\mathrm{CH}_{2} \mathrm{Cl}_{2}$ : $\mathrm{MeOH}$ 95:5 for elution. $144 \mathrm{mg}$, (97\%) of 32 are obtained. ${ }^{1} \mathrm{H}$ NMR (600 MHz, DMSO) $\delta 9.86(\mathrm{~s}, 1 \mathrm{H}), 8.05-7.98(\mathrm{~m}, 1 \mathrm{H}), 7.79$ $(\mathrm{td}, J=7.5,1.1 \mathrm{~Hz}, 1 \mathrm{H}), 7.76-7.69(\mathrm{~m}, 1 \mathrm{H}), 7.47-7.39(\mathrm{~m}, 2 \mathrm{H}), 7.32(\mathrm{~d}, J=7.4 \mathrm{~Hz}$, 1H), $7.27(\mathrm{~d}, J=7.6 \mathrm{~Hz}, 1 \mathrm{H}), 7.05-7.00(\mathrm{~m}, 1 \mathrm{H}), 6.63(\mathrm{~d}, J=2.1 \mathrm{~Hz}, 1 \mathrm{H}), 6.59(\mathrm{t}, J=6.5$ $\mathrm{Hz}, 1 \mathrm{H}), 6.43(\mathrm{~d}, J=8.5 \mathrm{~Hz}, 1 \mathrm{H}), 6.39(\mathrm{dd}, J=8.6,2.2 \mathrm{~Hz}, 1 \mathrm{H}), 5.69(\mathrm{~s}, 2 \mathrm{H}) .{ }^{13} \mathrm{C} \mathrm{NMR}$ (151 MHz, DMSO) $\delta 168.80,154.80,152.95,151.39,151.24,148.21,136.56,135.55$, $130.01,128.65,128.18,126.25,124.55,124.10,123.87,123.31,118.68,113.96,112.20$, 111.82, 111.72, 104.67, 99.58, 84.17. HR ESI $[\mathrm{M}+\mathrm{H}]^{+} \mathrm{m} / z$ 382.1081, calc for $\mathrm{C}_{24} \mathrm{H}_{16} \mathrm{NO}_{4}$ 382.1073. Compound $32(50 \mathrm{mg}, 131 \mu \mathrm{mol})$ is dissolved in $25 \mathrm{~mL}$ of anhydrous $\mathrm{MeOH}$. $0.750 \mathrm{~mL}$ of acetyl chloride is added dropwise. The mixture is stirred and heated at $50{ }^{\circ} \mathrm{C}$ 
for $48 \mathrm{~h} .0 .3 \mathrm{~mL}$ of acetyl chloride is added and the mixture is kept at $50{ }^{\circ} \mathrm{C}$ for additional $24 \mathrm{~h}$. The solvent is evaporated under vacuum. The title compound $\mathbf{3}$ is purified in a $\mathrm{C}_{18}$ reversed phase SPE cartridge using $\mathrm{MeOH}: \mathrm{H}_{2} \mathrm{O}$ 2:8, MeOH: $\mathrm{H}_{2} \mathrm{O}$ 1:1 for elution. Yield $45.44 \mathrm{mg}(88 \%) .{ }^{1} \mathrm{H}$ NMR (400 MHz, DMSO) $\delta 11.47(\mathrm{~s}, 1 \mathrm{H}), 8.91(\mathrm{~d}, J=15.4 \mathrm{~Hz}, 2 \mathrm{H})$, $8.34(\mathrm{dd}, J=7.9,1.0 \mathrm{~Hz}, 1 \mathrm{H}), 7.99(\mathrm{td}, J=7.5,1.3 \mathrm{~Hz}, 1 \mathrm{H}), 7.90(\mathrm{td}, J=7.7,1.3 \mathrm{~Hz}, 1 \mathrm{H})$, $7.85-7.77(\mathrm{~m}, 2 \mathrm{H}), 7.61-7.55(\mathrm{~m}, 2 \mathrm{H}), 7.36(\mathrm{~d}, J=7.2 \mathrm{~Hz}, 1 \mathrm{H}), 7.29(\mathrm{~d}, J=9.3 \mathrm{~Hz}$ 1H), $7.24-7.14(\mathrm{~m}, 2 \mathrm{H}), 7.02(\mathrm{~d}, J=9.0 \mathrm{~Hz}, 1 \mathrm{H}), 3.56(\mathrm{~s}, 3 \mathrm{H}) .{ }^{13} \mathrm{C} \mathrm{NMR}(101 \mathrm{MHz}$, DMSO) $\delta 165.09,161.45,160.00,158.19,157.57,154.18,138.39,133.70,133.59,133.52$, $131.77,130.97,130.75,130.42,129.08,127.17,122.51,121.50,119.26,117.47,117.10$, 114.08, 112.28, 96.84, 52.48. HR ESI [M] ${ }^{+} m / z$ 396.1240, calc. for $\mathrm{C}_{25} \mathrm{H}_{18} \mathrm{NO}_{4} 396.1230$.
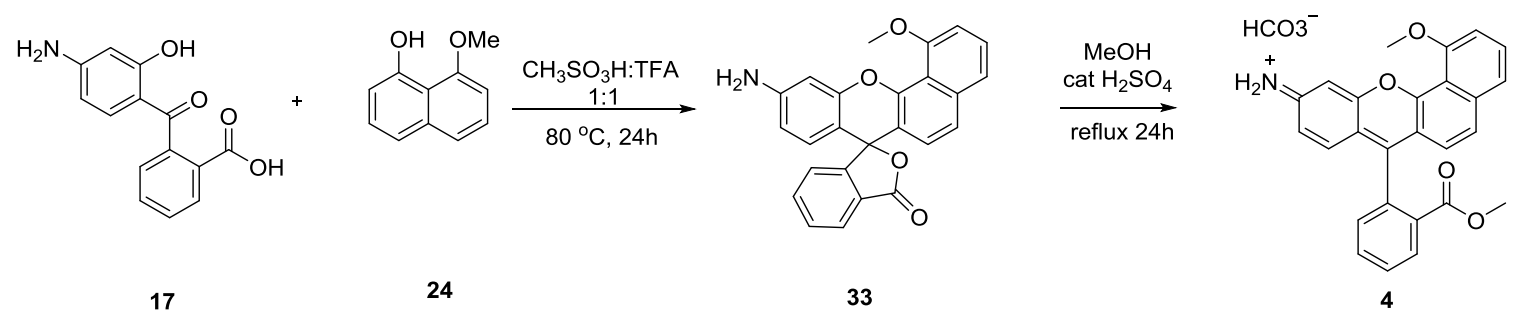

\subsection{Synthesis of 1-methoxy-7-(2-(methoxycarbonyl)phenyl)-10H- benzo[c]xanthen-10-iminium bicarbonate, 4 .}

Compound 17 (150 mg, $0.583 \mathrm{mmol})$, and compound 24 (152 mg, $0.875 \mathrm{mmol})$ are dissolved in $1 \mathrm{~mL}$ of methanesulfonic acid, then $1 \mathrm{~mL}$ of TFA is added. The mixture is stirred at $80^{\circ} \mathrm{C}$ for $16 \mathrm{~h}$. The mixture is cooled down to room temperature and poured into $50 \mathrm{~mL}$ of DI water. The mixture is neutralized to $\mathrm{pH}$ 6-7 by portion wise addition of solid $\mathrm{NaHCO}_{3}$. The precipitate formed is filtered and washed with water $(25 \mathrm{~mL})$, then air dried. 
The title compound $\mathbf{3 3}$ is isolated by flash column chromatography using $\mathrm{CH}_{2} \mathrm{Cl}_{2}: \mathrm{MeOH}$ 9:1 for elution. Yield $157 \mathrm{mg}(68 \%) .{ }^{1} \mathrm{H}$ NMR (400 MHz, DMSO) $\delta 8.05-7.99(\mathrm{~m}, 1 \mathrm{H})$, $7.78(\mathrm{dd}, J=7.5,1.2 \mathrm{~Hz}, 1 \mathrm{H}), 7.73(\mathrm{dd}, J=7.5,1.0 \mathrm{~Hz}, 1 \mathrm{H}), 7.56(\mathrm{t}, J=7.9 \mathrm{~Hz}, 1 \mathrm{H}), 7.47$ $(\mathrm{dd}, J=13.7,8.2 \mathrm{~Hz}, 2 \mathrm{H}), 7.29-7.24(\mathrm{~m}, 1 \mathrm{H}), 7.16(\mathrm{~d}, J=7.2 \mathrm{~Hz}, 1 \mathrm{H}), 6.65(\mathrm{~d}, J=8.7$ $\mathrm{Hz}, 1 \mathrm{H}), 6.60(\mathrm{~d}, J=2.0 \mathrm{~Hz}, 1 \mathrm{H}), 6.40(\mathrm{dt}, J=8.6,5.3 \mathrm{~Hz}, 2 \mathrm{H}), 5.68(\mathrm{~s}, 2 \mathrm{H}), 4.05(\mathrm{~s}, 3 \mathrm{H})$. ${ }^{13} \mathrm{C}$ NMR (101 MHz, DMSO) $\delta 168.83,157.04,153.02,151.59,151.31,148.04,136.49$, $135.58,130.04,128.46,128.17,126.22,124.58,124.42,124.14,123.19,120.30,114.95$, 112.83, 111.72, 108.26, 104.64, 99.48, 84.29, 56.42. HR ESI $[\mathrm{M}+\mathrm{H}]^{+} \mathrm{m} / z$ 396.1230, calc. for $\mathrm{C}_{25} \mathrm{H}_{18} \mathrm{NO}_{4}$ 396.1230. Compound $\mathbf{3 3}(50 \mathrm{mg}, 126 \mu \mathrm{mol})$ is dissolved in $2 \mathrm{~mL}$ of $\mathrm{MeOH}$. To this solution is added concentrated $\mathrm{H}_{2} \mathrm{SO}_{4}(100 \mu \mathrm{L})$ dropwise, then the mixture is refluxed for $24 \mathrm{~h}$. The mixture is allowed to cool down to room temperature, then poured into $50 \mathrm{~mL}$ of ice water and $200 \mathrm{mg}$ of $\mathrm{NaHCO}_{3}$ is added in one portion. The precipitate formed is washed with $2 \% \mathrm{NaHCO}_{3}(2 \times 10 \mathrm{~mL})$. The solid is transferred to a flask containing $50 \mathrm{~mL}$ of $2 \% \mathrm{HOAc}$. The $\mathrm{pH}$ of the solution is adjusted to 6-7 using $1 \mathrm{M} \mathrm{NaOH}$. The aqueous phase is extracted with $\mathrm{CHCl}_{3}(3 \times 100 \mathrm{~mL})$. The organic phase is dried over anhydrous $\mathrm{Na}_{2} \mathrm{SO}_{4}$ and the solvent evaporated under vacuum to leave a dark purple solid. The title compound $\mathbf{4}$ is isolated by flash column chromatography on silica gel using $\mathrm{CH}_{2} \mathrm{Cl}_{2}: \mathrm{MeOH}$ 9:1 for elution. Yield $49 \mathrm{mg}, 94 \% .{ }^{1} \mathrm{H}$ NMR (400 MHz, DMSO) $\delta 8.97$ (d, $J=5.3 \mathrm{~Hz}, 2 \mathrm{H}), 8.34(\mathrm{dd}, J=7.9,1.0 \mathrm{~Hz}, 1 \mathrm{H}), 8.04-7.85(\mathrm{~m}, 4 \mathrm{H}), 7.72(\mathrm{~d}, J=7.8 \mathrm{~Hz}$, 1H), $7.57(\mathrm{dd}, J=7.6,1.0 \mathrm{~Hz}, 1 \mathrm{H}), 7.49(\mathrm{~d}, J=7.8 \mathrm{~Hz}, 1 \mathrm{H}), 7.30(\mathrm{~d}, J=9.3 \mathrm{~Hz}, 1 \mathrm{H}), 7.24$ $-7.14(\mathrm{~m}, 2 \mathrm{H}), 7.10(\mathrm{~d}, J=8.9 \mathrm{~Hz}, 1 \mathrm{H}), 4.22(\mathrm{~s}, 3 \mathrm{H}), 3.54(\mathrm{~s}, 3 \mathrm{H}) .{ }^{13} \mathrm{C} \mathrm{NMR}(101 \mathrm{MHz}$, DMSO) $\delta 165.07,161.76,160.07,158.44,158.33,153.23,138.40,133.62,133.54,133.33$, $131.96,131.00,130.80,130.43,129.09,127.03,123.23,121.82,120.86,117.96,117.43$, 
113.08, 109.82, 96.87, 56.82, 52.77, 52.48. HR ESI $[\mathrm{M}]^{+} \mathrm{m} / \mathrm{z} 410.1400$, calc. for $\mathrm{C}_{26} \mathrm{H}_{20} \mathrm{NO}_{4} 410.1386$.

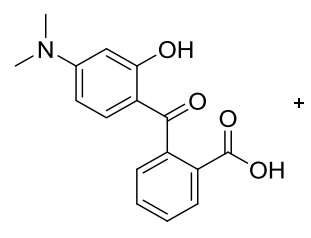

20

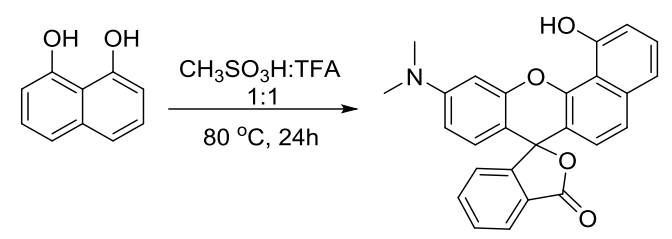

23

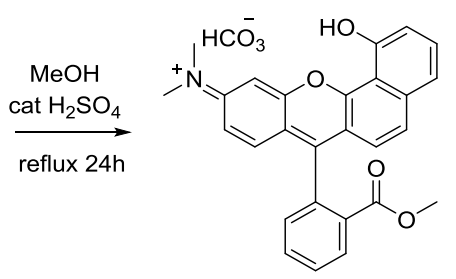

5

\subsection{N-(1-hydroxy-7-(2-(methoxycarbonyl)phenyl)-10H-benzo[c]xanthen-10-} yliden)-N-N-dimethyl iminium bicarbonate, 5 .

Compound $20(0.750 \mathrm{~g}, 2.63 \mathrm{mmol})$ and $23(0.632 \mathrm{~g}, 3.94 \mathrm{mmol})$ are dissolved in $6.5 \mathrm{~mL}$ of methanesulfonic acid, then TFA $(6.5 \mathrm{~mL})$ are added. The mixture is heated at 80 ${ }^{\circ} \mathrm{C}$ for $24 \mathrm{~h}$, then allowed to cool down to room temperature. The mixture is poured into 300 $\mathrm{mL}$ of DI water, the purple solid is filtered and washed with water $(3 \times 100 \mathrm{~mL})$, then dried under vacuum. The target compound $\mathbf{3 4}$ is separated by flash chromatography on silica gel using $\mathrm{CHCl}_{3}: \mathrm{MeOH}$ 9:1 for elution. Yield $0.778 \mathrm{~g}, 72 \%$. ${ }^{1} \mathrm{H}$ NMR $\left(400 \mathrm{MHz}, \mathrm{CDCl}_{3}\right) \delta$ $9.12(\mathrm{~s}, 1 \mathrm{H}), 8.08-8.04(\mathrm{~m}, 1 \mathrm{H}), 7.65(\mathrm{dqd}, J=14.4,7.3,1.3 \mathrm{~Hz}, 2 \mathrm{H}), 7.47(\mathrm{t}, J=7.9 \mathrm{~Hz}$, $1 \mathrm{H}), 7.41(\mathrm{~d}, J=8.8 \mathrm{~Hz}, 1 \mathrm{H}), 7.32(\mathrm{dd}, J=8.1,0.9 \mathrm{~Hz}, 1 \mathrm{H}), 7.18-7.15(\mathrm{~m}, 1 \mathrm{H}), 7.08(\mathrm{dd}$, $J=7.7,1.0 \mathrm{~Hz}, 1 \mathrm{H}), 6.69(\mathrm{dd}, J=8.8,4.2 \mathrm{~Hz}, 2 \mathrm{H}), 6.55-6.48(\mathrm{~m}, 2 \mathrm{H}), 3.03(\mathrm{~s}, 6 \mathrm{H}) .{ }^{13} \mathrm{C}$ NMR $\left(101 \mathrm{MHz}, \mathrm{CDCl}_{3}\right) \delta 169.70,154.32,153.52,152.23,150.95,148.59,136.63$, $135.18,129.88,129.16,129.00,126.97,125.23,124.43,124.11,124.06,119.69,113.38$, 112.72, 112.56, 110.23, 105.84, 97.93, 83.39, 40.44. HR ESI $[\mathrm{M}+\mathrm{H}]^{+}$found 410.1392, calc. for $\mathrm{C}_{26} \mathrm{H}_{20} \mathrm{NO}_{4} 410.1368$. Compound $34(100 \mathrm{mg}, 243 \mu \mathrm{mol})$ is dissolved in $2 \mathrm{~mL}$ of 
$\mathrm{MeOH}$. To this solution is added concentrated $\mathrm{H}_{2} \mathrm{SO}_{4}(100 \mu \mathrm{L})$ dropwise, then the mixture is refluxed for $16 \mathrm{~h}$. The mixture is allowed to cool down to room temperature, then poured into $50 \mathrm{~mL}$ of ice water and filtered. The precipitate is washed with $2 \% \mathrm{NaHCO}_{3}(2 \times 10$ $\mathrm{mL}$ ). The solid is transferred to a flask containing $50 \mathrm{~mL}$ of $2 \%$ HOAc. The $\mathrm{pH}$ of the solution is adjusted to 6-7 using $1 \mathrm{M} \mathrm{NaOH}$. The aqueous phase is extracted with $\mathrm{CHCl}_{3}$ $(3 \times 100 \mathrm{~mL})$. The organic phase is dried over anhydrous $\mathrm{Na}_{2} \mathrm{SO}_{4}$ and the solvent evaporated under vacuum to leave a dark purple solid. The target compound $\mathbf{5}$ is isolated by flash column chromatography. A dark purple band is eluted with $\mathrm{CHCl}_{3}: \mathrm{MeOH}$ 9:1, 8:2; yield $36 \mathrm{mg}$. A second green band was eluted with $\mathrm{CHCl}_{3}: \mathrm{MeOH} 1: 1$, then 1:3; yield $61 \mathrm{mg}$. Total yield of 34, $97 \mathrm{mg},(94 \%) .{ }^{1} \mathrm{H}$ NMR (400 MHz, DMSO) $\delta 8.32(\mathrm{~d}, J=7.0$ Hz, 1H), $7.97(\mathrm{~d}, J=7.5 \mathrm{~Hz}, 1 \mathrm{H}), 7.89(\mathrm{t}, J=7.1 \mathrm{~Hz}, 1 \mathrm{H}), 7.72(\mathrm{t}, J=8.6 \mathrm{~Hz}, 2 \mathrm{H}), 7.58$ $(\mathrm{d}, J=6.7 \mathrm{~Hz}, 1 \mathrm{H}), 7.43-7.34(\mathrm{~m}, 2 \mathrm{H}), 7.26(\mathrm{~d}, J=8.1 \mathrm{~Hz}, 1 \mathrm{H}), 7.20(\mathrm{~d}, J=9.6 \mathrm{~Hz}, 1 \mathrm{H})$, $7.09(\mathrm{~d}, J=2.4 \mathrm{~Hz}, 1 \mathrm{H}), 6.93(\mathrm{~d}, J=9.0 \mathrm{~Hz}, 1 \mathrm{H}), 3.54(\mathrm{~s}, 3 \mathrm{H}), 3.39(\mathrm{~s}, 6 \mathrm{H}) .{ }^{13} \mathrm{C}$ NMR $(101$ MHz, DMSO) $\delta$ 165.29, 158.40, 154.28, 153.85, 138.93, 135.22, 134.73, 133.24, 130.70, 129.87, 128.79, 127.72, 124.06, 120.52, 117.48, 113.21, 96.43, 94.54, 79.25, 52.13. HR ESI $\left[\mathrm{M}^{+}\right] \mathrm{m} / 2,424.1540$, calc for $\mathrm{C}_{27} \mathrm{H}_{22} \mathrm{NO}_{4}{ }^{+} 424.1543$.

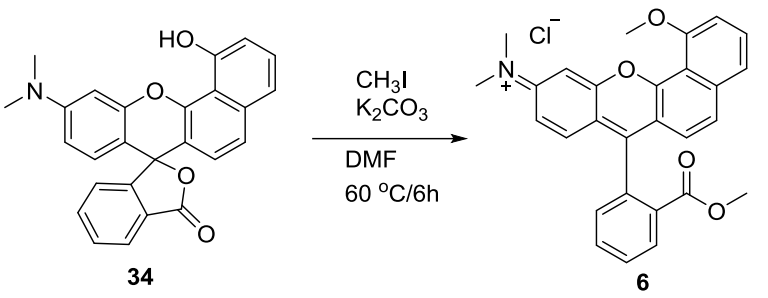




\section{$2.12 N$-(1-methoxy-7-(2-(methoxycarbonyl)phenyl)-10H-benzo[c]xanthen-10- ylidene )-N-methylmethanaminium chloride, 6 .}

Compound 34 (50 mg, $0.122 \mathrm{mmol}), \mathrm{K}_{2} \mathrm{CO}_{3}(67.5 \mathrm{mg}, 0.488 \mathrm{mmol})$ are suspended in $0.6 \mathrm{~mL}$ of anhydrous $\mathrm{DMF}, \mathrm{CH}_{3} \mathrm{I}(104 \mathrm{mg}, 0.732 \mathrm{mmol})$ is added in one portion. The

mixture is stirred at $60{ }^{\circ} \mathrm{C}$ for $6 \mathrm{~h}$, then allowed to cool down to room temperature. $2 \mathrm{~mL}$ of saturated $\mathrm{NH}_{4} \mathrm{Cl}$ are added to quench the reaction. The precipitate formed is filtered and washed with $0.5 \% \mathrm{NaOH}(2 \mathrm{~mL})$, then with water $(25 \mathrm{~mL})$. The title compound 6 is isolated by flash column chromatography on silica gel using $\mathrm{CH}_{2} \mathrm{Cl}_{2}: \mathrm{MeOH}$ 9:1 for elution. Yield: $4.5 \mathrm{mg},(8 \%) .{ }^{1} \mathrm{H} \mathrm{NMR}\left(400 \mathrm{MHz}, \mathrm{CDCl}_{3}\right) \delta 8.36(\mathrm{~d}, J=7.9 \mathrm{~Hz}, 1 \mathrm{H}), 7.87$ (d, $J=7.5 \mathrm{~Hz}$ 1H), $7.84-7.77(\mathrm{~m}, 2 \mathrm{H}), 7.66(\mathrm{~d}, J=9.0 \mathrm{~Hz}, 1 \mathrm{H}), 7.61(\mathrm{dd}, J=9.7,2.0 \mathrm{~Hz}, 1 \mathrm{H}), 7.53(\mathrm{~d}$, $J=7.7 \mathrm{~Hz}, 1 \mathrm{H}), 7.40(\mathrm{~d}, J=7.5 \mathrm{~Hz}, 1 \mathrm{H}), 7.35(\mathrm{~d}, J=9.7 \mathrm{~Hz}, 1 \mathrm{H}), 7.24(\mathrm{~s}, 1 \mathrm{H}), 7.13(\mathrm{~s}$, 1H), $7.09(\mathrm{~d}, J=8.9 \mathrm{~Hz}, 1 \mathrm{H}), 4.30(\mathrm{~s}, 3 \mathrm{H}), 3.63(\mathrm{~s}, 3 \mathrm{H}), 3.59(\mathrm{~s}, 6 \mathrm{H}) .{ }^{13} \mathrm{C} \mathrm{NMR}(101 \mathrm{MHz}$, $\left.\mathrm{CDCl}_{3}\right) \delta 165.45,160.65,159.55,159.11,158.31,154.73,139.21,134.11,133.58,133.39$ $131.66,131.12,130.89,130.39,129.82,127.38,123.24,120.99,119.99,118.60,117.63$, 114.24, 109.24, 96.78, 57.11, 52.76, 42.53, 29.84. HR ESI $\left[\mathrm{M}^{+}\right] \mathrm{m} / z$ 438.1698, calc for $\mathrm{C}_{28} \mathrm{H}_{24} \mathrm{NO}_{4}{ }^{+} ; 438.1699$.

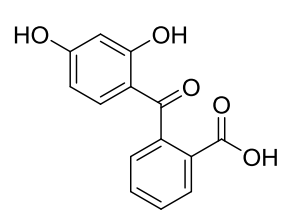

15

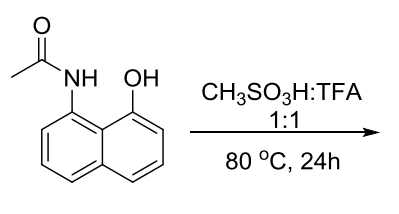

28

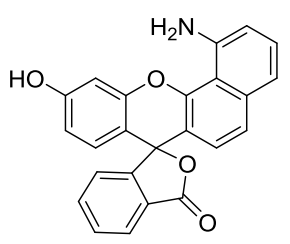

35

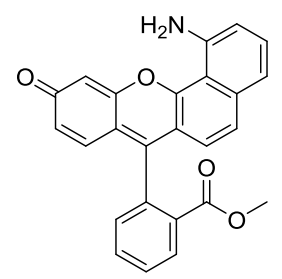

7 


\subsection{Synthesis of methyl 2-(1-amino-10-oxo-10H-benzo[c]xanthen-7-yl)benzoate 7 .}

Compound 15 (200 mg, $0.774 \mathrm{mmol}$ ), and compound 28 (234 mg, $1.16 \mathrm{mmol}$ ) are dissolved in $2.5 \mathrm{~mL}$ of methanesulfonic acid, then $2.5 \mathrm{~mL}$ of TFA are added. The mixture is stirred at $80{ }^{\circ} \mathrm{C}$ for $24 \mathrm{~h}$, then cooled down to room temperature. The mixture is poured into $50 \mathrm{~mL}$ of DI water, the precipitate obtained is filtered and washed with DI water, then air dried. The title compound is isolated by flash column chromatography on silica gel using $\mathrm{CH}_{2} \mathrm{Cl}_{2}: \mathrm{MeOH}$ 9:1. $33 \mathrm{mg}$ of a mixed fraction containing the target product $\mathbf{3 5}$ is isolated. $17 \mathrm{mg}$ of the $\mathbf{3 5}$ mixed fraction are dissolved in $1 \mathrm{~mL}$ of $\mathrm{MeOH}, 50 \mu \mathrm{L}$ of concentrated sulfuric acid are added in one portion. The mixture is refluxed for $16 \mathrm{~h}$, the mixture is allowed to cool down to room temperature and poured into $10 \mathrm{~mL}$ of DI water. $200 \mathrm{mg}$ of $\mathrm{NaHCO}_{3}$ is added in one portion. The precipitate formed is filtered and washed with aqueous $2 \% \mathrm{NaHCO}_{3}$, the precipitate is then suspended in $25 \mathrm{~mL}$ of $2 \% \mathrm{HOAc}$, a dark brown black suspension is obtained, the mixture is neutralized to $\mathrm{pH} \mathrm{6-7} \mathrm{by} \mathrm{adding} \mathrm{solid}$ $\mathrm{NaHCO}_{3}$ portion wise. The aqueous phase is extracted with $\mathrm{CHCl}_{3}(3 \times 50 \mathrm{~mL})$, the organic extracts are combined, dried over anhydrous $\mathrm{Na}_{2} \mathrm{SO}_{4}$, filtered and the solvent evaporated under vacuum to leave a black precipitate. The title compound $\mathbf{7}$ is isolated by flash column chromatography on silica gel using $\mathrm{CH}_{2} \mathrm{Cl}_{2}: \mathrm{MeOH} 9: 1$ for elution. Yield $2.7 \mathrm{mg}, 15 \% .{ }^{1} \mathrm{H}$ NMR (400 MHz, CDCl $) \delta 8.29(\mathrm{dd}, J=7.8,1.1 \mathrm{~Hz}, 1 \mathrm{H}), 7.78(\mathrm{td}, J=7.5,1.4 \mathrm{~Hz}, 1 \mathrm{H})$, $7.71(\mathrm{td}, J=7.7,1.4 \mathrm{~Hz}, 1 \mathrm{H}), 7.47$ (t, $J=7.9 \mathrm{~Hz}, 1 \mathrm{H}), 7.41(\mathrm{~d}, J=8.9 \mathrm{~Hz}, 1 \mathrm{H}), 7.35$ (dd, $J=7.5,1.0 \mathrm{~Hz}, 1 \mathrm{H}), 7.17(\mathrm{~d}, J=7.7 \mathrm{~Hz}, 1 \mathrm{H}), 6.94(\mathrm{~d}, J=9.6 \mathrm{~Hz}, 1 \mathrm{H}), 6.86(\mathrm{~d}, J=7.8 \mathrm{~Hz}$, $1 \mathrm{H}), 6.82(\mathrm{~d}, J=8.9 \mathrm{~Hz}, 1 \mathrm{H}), 6.68(\mathrm{dd}, J=9.6,1.9 \mathrm{~Hz}, 1 \mathrm{H}), 6.63(\mathrm{~d}, J=1.9 \mathrm{~Hz}, 1 \mathrm{H}), 5.69$ (s, 2H), $3.63(\mathrm{~s}, 3 \mathrm{H}) .{ }^{13} \mathrm{C}$ NMR $\left(101 \mathrm{MHz}, \mathrm{CDCl}_{3}\right) \delta 185.06,158.17,146.15,137.97$, 
$135.26,132.99,131.36,131.30,130.72,129.90,129.82,125.81,122.57,117.43,112.65$,

111.41, 105.15, 52.60. HR ESI $\left[\mathrm{M}+\mathrm{H}^{+}\right] \mathrm{m} / z$ 396.1240, calc for $\mathrm{C}_{25} \mathrm{H}_{18} \mathrm{NO}_{4}{ }^{+} 396.1230$.

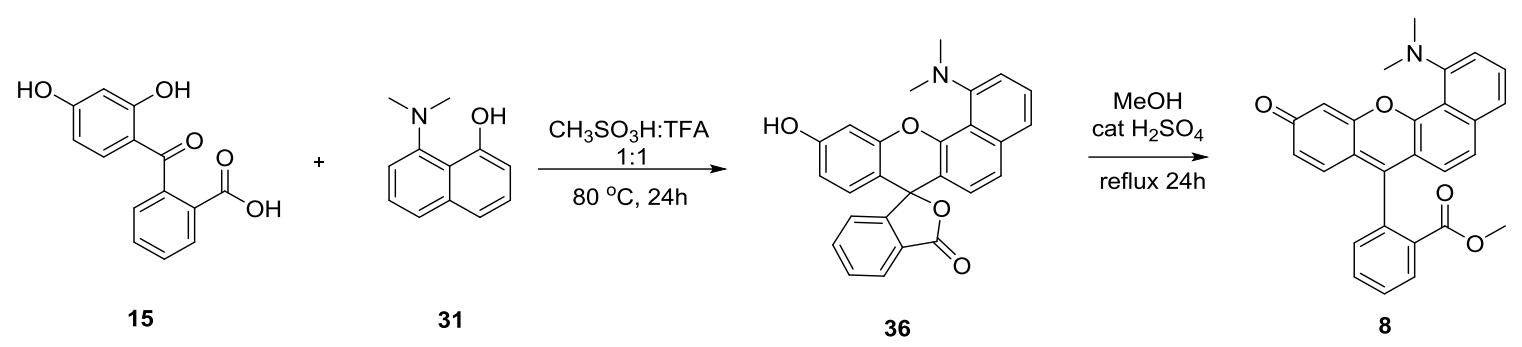

\subsection{Synthesis of methyl 2-(1-(dimethylamino)-10-oxo-10H-benzo[c]xanthen-7-}

\section{yl)benzoate, 8 .}

Compound 15 (200 mg, $0.774 \mathrm{mmol}$ ), compound 31 (217.5 mg, $1.16 \mathrm{mmol})$ are dissolved in $2.5 \mathrm{~mL}$ of methanesulfonic acid, then $2.5 \mathrm{~mL}$ of TFA is added. The mixture is stirred at $80{ }^{\circ} \mathrm{C}$ for $24 \mathrm{~h}$, then cooled down to room temperature. The mixture is poured into $50 \mathrm{~mL}$ of DI water, the precipitate obtained is filtered and washed with DI water, then air dried. The crude mixture is separated by flash column chromatography on silica gel using $\mathrm{CH}_{2} \mathrm{Cl}_{2}: \mathrm{MeOH}$ 95:5 for elution; $15 \mathrm{mg}$ of a mixed fraction containing $\mathbf{3 6}$ is isolated. $10 \mathrm{mg}$ of the 36 mixed fraction are dissolved in $1 \mathrm{~mL}$ of $\mathrm{MeOH}, 50 \mu \mathrm{l}$ of concentrated Sulfuric acid is added in one portion. The mixture is refluxed for $16 \mathrm{~h}$, the mixture is allowed to cool down to room temperature and poured into $10 \mathrm{~mL}$ of DI water. $200 \mathrm{mg}$ of $\mathrm{NaHCO}_{3}$ are added in one portion. The precipitate formed is filtered and washed with aqueous $2 \% \mathrm{NaHCO}_{3}$, the precipitate is then suspended in $25 \mathrm{~mL}$ of $2 \% \mathrm{HOAc}$. The mixture is neutralized to $\mathrm{pH}$ 6-7 by adding solid $\mathrm{NaHCO}_{3}$ portion wise. The aqueous phase is extracted with $\mathrm{CHCl}_{3}(3 \times 50 \mathrm{~mL})$, the organic extracts are combined, dried over anhydrous $\mathrm{Na}_{2} \mathrm{SO}_{4}$, filtered and the solvent evaporated under vacuum. The crude mixture was separated by flash column chromatography on silica gel using $\mathrm{CH}_{2} \mathrm{Cl}_{2}: \mathrm{MeOH}$ 9:1 for 
elution. The isolated fraction $(5.9 \mathrm{mg})$ containing the target product 8 was further separated by flash column chromatography on silica gel using EtOAc:MeOH 95:5 for elution. Yield, $1.5 \mathrm{mg},(14.5 \%) .{ }^{1} \mathrm{H} \mathrm{NMR}\left(400 \mathrm{MHz}, \mathrm{CDCl}_{3}\right) \delta 8.29(\mathrm{dd}, J=7.8,1.1 \mathrm{~Hz}, 1 \mathrm{H}), 7.77(\mathrm{td}, J$ $=7.5,1.5 \mathrm{~Hz}, 1 \mathrm{H}), 7.70(\mathrm{td}, J=7.7,1.4 \mathrm{~Hz}, 1 \mathrm{H}), 7.56(\mathrm{t}, J=7.9 \mathrm{~Hz}, 1 \mathrm{H}), 7.47(\mathrm{~d}, J=8.9$ $\mathrm{Hz}, 1 \mathrm{H}), 7.39(\mathrm{~d}, J=7.3 \mathrm{~Hz}, 1 \mathrm{H}), 7.36(\mathrm{dd}, J=7.5,1.0 \mathrm{~Hz}, 1 \mathrm{H}), 7.21(\mathrm{dd}, J=7.8,0.9 \mathrm{~Hz}$, 1H), $6.92(\mathrm{dd}, J=9.1,7.4 \mathrm{~Hz}, 2 \mathrm{H}), 6.70(\mathrm{~s}, 2 \mathrm{H}), 3.59$ (s, 3H), $3.04(\mathrm{~s}, 6 \mathrm{H}) .{ }^{13} \mathrm{C}$ NMR $(101$ $\left.\mathrm{MHz}, \mathrm{CDCl}_{3}\right) \delta 165.77,158.79,152.34,138.80,135.39,132.90,131.35,131.12,130.80$, $130.54,130.21,129.80,129.52,125.54,123.04,121.50,117.37,116.79,116.12,105.25$, 52.52, 45.39. HR ESI $\left[\mathrm{M}^{+}\right] \mathrm{m} / z$ 424.1556, calc for $\mathrm{C}_{27} \mathrm{H}_{22} \mathrm{NO}_{4}{ }^{+} 424.1543$.
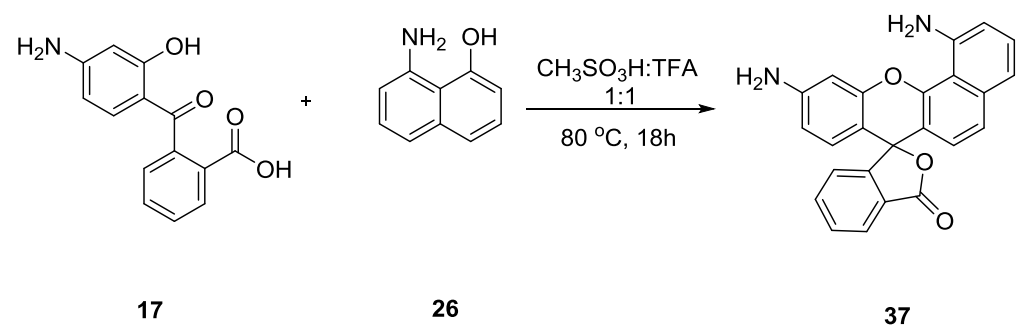

37

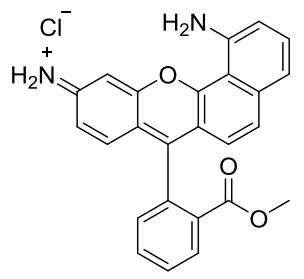

9

\subsection{Synthesis of 1-amino-7-(2-(methoxycarbonyl)phenyl)-10H-benzo[c]xanthen-}

\section{0-iminium chloride, 9.}

Compound 17 (310 mg, $1.21 \mathrm{mmol})$, 8-aminonaphthalen-1-ol (26) (287.75 mg, $1.81 \mathrm{mmol}$ ) are dissolved in $4.5 \mathrm{~mL}$ of methanesulfonic acid, then $4.5 \mathrm{~mL}$ of TFA is added. The mixture is stirred at $80^{\circ} \mathrm{C}$ for $18 \mathrm{~h}$, then cooled down to room temperature. The mixture is poured into $60 \mathrm{~mL}$ of $\mathrm{DI}$ water, the mixture is brought to $\mathrm{pH} 5$ by portion wise addition of solid $\mathrm{NaHCO}_{3}$. The dark green precipitate obtained is filtered and washed with DI water. The title compound $\mathbf{3 7}$ is isolated by flash column chromatography on silica gel using $\mathrm{CH}_{2} \mathrm{Cl}_{2}: \mathrm{MeOH}$ 9:1 for elution. Yield $254.9 \mathrm{mg}, 56 \%$. ${ }^{1} \mathrm{H}$ NMR (400 MHz, DMSO) $\delta 8.01$ $(\mathrm{d}, J=7.6 \mathrm{~Hz}, 1 \mathrm{H}), 7.80(\mathrm{td}, J=7.5,1.1 \mathrm{~Hz}, 1 \mathrm{H}), 7.72(\mathrm{td}, J=7.5,0.7 \mathrm{~Hz}, 1 \mathrm{H}), 7.36-$ 
$7.25(\mathrm{~m}, 3 \mathrm{H}), 7.00(\mathrm{~d}, J=7.6 \mathrm{~Hz}, 1 \mathrm{H}), 6.82(\mathrm{dd}, J=7.7,0.7 \mathrm{~Hz}, 1 \mathrm{H}), 6.71(\mathrm{~d}, J=1.8 \mathrm{~Hz}$, $1 \mathrm{H}), 6.48(\mathrm{~d}, J=8.7 \mathrm{~Hz}, 1 \mathrm{H}), 6.43(\mathrm{~d}, J=2.6 \mathrm{~Hz}, 1 \mathrm{H}), 6.35(\mathrm{~s}, 2 \mathrm{H}), 5.69(\mathrm{~s}, 2 \mathrm{H}) .{ }^{13} \mathrm{C} \mathrm{NMR}$ (101 MHz, DMSO) $\delta 168.81,152.83,151.27,150.99,149.26,146.12,136.51,135.56$, 130.04, 128.83, 128.31, 126.32, 124.58, 124.11, 123.88, 123.27, 115.01, 111.96, 111.69, 110.79, 110.69, 104.78, 99.30, 84.15. HR ESI $[\mathrm{M}+\mathrm{H}]^{+} \mathrm{m} / \mathrm{z} 381.1232$, calc. for $\mathrm{C}_{24} \mathrm{H}_{17} \mathrm{~N}_{2} \mathrm{O}_{3} 381.1233$. Compound 37 ( $\left.25 \mathrm{mg}, 66 \mu \mathrm{mol}\right)$ is dissolved in $20 \mathrm{~mL}$ of anhydrous $\mathrm{MeOH} ; 1.0 \mathrm{~mL}$ of acetyl chloride is added drop wise. The mixture is stirred and heated at $50{ }^{\circ} \mathrm{C}$ for $48 \mathrm{~h} ; 0.5 \mathrm{~mL}$ of acetyl chloride is added and the mixture is kept at $50{ }^{\circ} \mathrm{C}$ for additional $24 \mathrm{~h}$. The solvent is evaporated under vacuum. The title compound 9 is isolated by flash column chromatography on silica gel using $\mathrm{CH}_{2} \mathrm{Cl}_{2}: \mathrm{MeOH}$ 90:10, 85:15, 80:20 for elution. Yield $24 \mathrm{mg}, 93 \% .{ }^{1} \mathrm{H}$ NMR (400 MHz, DMSO) $\delta 8.70(\mathrm{~s}, 2 \mathrm{H}), 8.32(\mathrm{~d}, J=$ $6.9 \mathrm{~Hz}, 1 \mathrm{H}), 7.99-7.94(\mathrm{~m}, 1 \mathrm{H}), 7.88(\mathrm{dd}, J=10.9,4.5 \mathrm{~Hz}, 1 \mathrm{H}), 7.70-7.63(\mathrm{~m}, 1 \mathrm{H}), 7.55$ (dd, $J=7.6,1.0 \mathrm{~Hz}, 1 \mathrm{H}), 7.47(\mathrm{~d}, J=2.0 \mathrm{~Hz}, 1 \mathrm{H}), 7.33(\mathrm{~s}, 2 \mathrm{H}), 7.23-7.13(\mathrm{~m}, 4 \mathrm{H}), 6.86$ $(\mathrm{d}, J=9.0 \mathrm{~Hz}, 2 \mathrm{H}), 3.56$ (s, 3H). ${ }^{13} \mathrm{C}$ NMR (101 MHz, DMSO) $\delta$ 165.08, 160.42, 158.80, $157.07,156.39,149.40,137.94,134.03,133.90,133.49,131.31,130.92,130.64,130.42$, $129.10,127.83,121.75,120.61,116.80,115.91,115.79,113.85,108.57,97.90,52.46 . \mathrm{HR}$ ESI $[\mathrm{M}]^{+} m / z$ 395.1386, calc. for $\mathrm{C}_{25} \mathrm{H}_{19} \mathrm{~N}_{2} \mathrm{O}_{3}{ }^{+} 395.1390$.

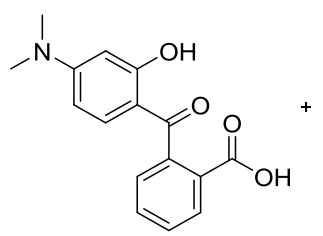

20

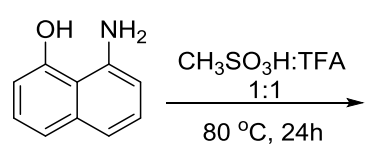

26

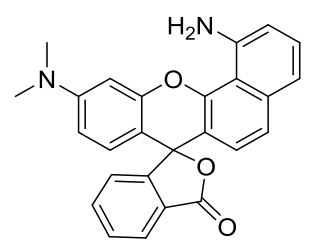

38

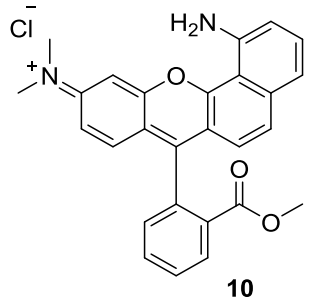




\subsection{Synthesis of N-(1-amino-7-(2-(methoxycarbonyl)phenyl)-10H- benzo[c]xanthen -10-ylidene)-N-methylmethanaminium, 10.}

Compound 20 (450 mg, 1.58 mmol), 8-aminonaphthalen-1-ol (26) (326.41 mg, $2.05 \mathrm{mmol}$ ) are dissolved in $2 \mathrm{~mL}$ of methanesulfonic acid, then $2 \mathrm{~mL}$ of TFA is added. The mixture is stirred at $80{ }^{\circ} \mathrm{C}$ for $24 \mathrm{~h}$, then cooled down to room temperature. The mixture is poured into $150 \mathrm{~mL}$ of $\mathrm{DI}$ water, the mixture is neutralized by portion wise addition of $\mathrm{NaHCO}_{3}$, the dark green precipitate obtained is filtered and washed with DI water then air dried. The target compound $\mathbf{3 8}$ is isolated by flash column chromatography on silica gel using $\mathrm{CH}_{2} \mathrm{Cl}_{2}: \mathrm{MeOH}$ 95:5, 9:1, Yield $265 \mathrm{mg}, 41 \% .{ }^{1} \mathrm{H}$ NMR (400 MHz, DMSO) $\delta 8.03$ $(\mathrm{d}, J=7.4 \mathrm{~Hz}, 1 \mathrm{H}), 7.79(\mathrm{dt}, J=7.5,3.8 \mathrm{~Hz}, 1 \mathrm{H}), 7.73(\mathrm{dt}, J=7.4,3.7 \mathrm{~Hz}, 1 \mathrm{H}), 7.37-$ $7.24(\mathrm{~m}, 3 \mathrm{H}), 6.98(\mathrm{dd}, J=10.7,4.6 \mathrm{~Hz}, 2 \mathrm{H}), 6.87(\mathrm{~d}, J=7.8 \mathrm{~Hz}, 1 \mathrm{H}), 6.59-6.56(\mathrm{~m}, 2 \mathrm{H})$, $6.50(\mathrm{~d}, J=8.7 \mathrm{~Hz}, 1 \mathrm{H}), 6.37(\mathrm{~s}, 2 \mathrm{H}), 2.99(\mathrm{~s}, 6 \mathrm{H}) .{ }^{13} \mathrm{C} \mathrm{NMR}(101 \mathrm{MHz}, \mathrm{DMSO}) \delta 168.81$, $152.93,152.03,151.06,149.38,146.16,136.58,135.60,130.09,128.85,128.09,126.22$, $124.63,124.09,123.99,123.22,114.82,111.58,110.81,110.49,109.99,105.02,98.69$, 83.96. HR ESI $\left[\mathrm{M}+\mathrm{H}^{+}\right] \mathrm{m} / z$ 409.15743, calc. for $\mathrm{C}_{26} \mathrm{H}_{21} \mathrm{~N}_{2} \mathrm{O}_{3}{ }^{+}$409.15466. Under Ar, compound 38 (25 mg, $0.043 \mathrm{mmol})$ is dissolved in $12.5 \mathrm{~mL}$ of anhydrous $\mathrm{MeOH}$. The solution is cooled down to $0{ }^{\circ} \mathrm{C}$ in an ice bath, $0.375 \mathrm{~mL}$ of acetyl chloride is added drop wise. The mixture is stirred and heated at $50{ }^{\circ} \mathrm{C}$ for $48 \mathrm{~h} ; 0.2 \mathrm{~mL}$ of acetyl chloride is added and the mixture is kept at $50{ }^{\circ} \mathrm{C}$ for additional $24 \mathrm{~h}$. The solvent is evaporated under vacuum. $27 \mathrm{mg}$ (96\%) of 10 are obtained. ${ }^{1} \mathrm{H}$ NMR (400 MHz, DMSO) $\delta 8.33$ (dd, $J=7.9$, $1.0 \mathrm{~Hz}, 1 \mathrm{H}), 7.97(\mathrm{td}, J=7.5,1.3 \mathrm{~Hz}, 1 \mathrm{H}), 7.92-7.85(\mathrm{~m}, 2 \mathrm{H}), 7.68(\mathrm{dd}, J=16.6,8.6 \mathrm{~Hz}$, 2H), $7.56(\mathrm{dd}, J=7.6,1.0 \mathrm{~Hz}, 1 \mathrm{H}), 7.43-7.34(\mathrm{~m}, 3 \mathrm{H}), 7.26-7.16(\mathrm{~m}, 3 \mathrm{H}), 6.87(\mathrm{~d}, J=$ $9.0 \mathrm{~Hz}, 1 \mathrm{H}), 3.55(\mathrm{~s}, 3 \mathrm{H}), 3.38(\mathrm{~d}, J=8.3 \mathrm{~Hz}, 6 \mathrm{H}) .{ }^{13} \mathrm{C} \mathrm{NMR}(101 \mathrm{MHz}, \mathrm{DMSO}) \delta 165.10$, 
$158.47,157.60,156.82,156.39,149.34,137.95,133.89,133.52,130.96,130.69,130.41$, $129.13,127.95,121.73,117.08,115.74,115.55,113.83,108.24,97.33,52.77,52.48$. HR ESI $\left[\mathrm{M}^{+}\right] m / z 423.17298$, calc. for $\mathrm{C}_{27} \mathrm{H}_{23} \mathrm{~N}_{2} \mathrm{O}_{3}{ }^{+} 423.17031$.

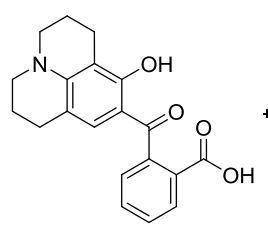

22

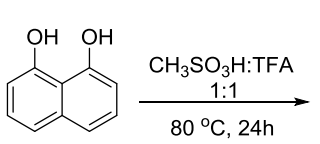

23

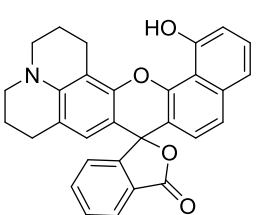

39

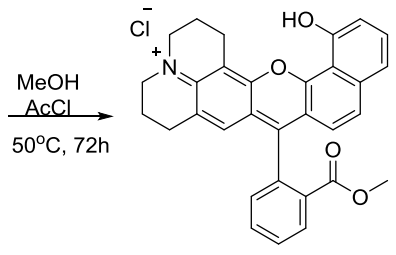

11

\subsection{Synthesis of 15-hydroxy-9-(2-(methoxycarbonyl)phenyl)-1,2,3,5,6,7-} hexahydrobenzo [7,8] chromeno[2,3-f]pyrido[3,2,1-ij]quinolin-4-ium chloride, 11.

Compound 22 (200 mg, $0.593 \mathrm{mmol}$ ), 1,8-dihydroxynaphthalene (23) (142 mg, $0.889 \mathrm{mmol}$ ) are dissolved in $1.5 \mathrm{~mL}$ of methanesulfonic acid, then $1.5 \mathrm{~mL}$ of TFA is added. The mixture is stirred at $80{ }^{\circ} \mathrm{C}$ for $24 \mathrm{~h}$, then cooled down to room temperature. The mixture is poured into $50 \mathrm{~mL}$ of $\mathrm{DI}$ water, the precipitate obtained is filtered and washed with DI water then dried under vacuum. $256 \mathrm{mg}$ (93\%) of $\mathbf{3 9}$ are obtained. ${ }^{1} \mathrm{H}$ NMR (400 MHz, DMSO) $\delta 11.39(\mathrm{~s}, 1 \mathrm{H}), 8.27(\mathrm{~d}, J=7.7 \mathrm{~Hz}, 1 \mathrm{H}), 7.90(\mathrm{t}, J=7.3 \mathrm{~Hz}, 1 \mathrm{H}), 7.83(\mathrm{t}, J$ $=7.5 \mathrm{~Hz}, 1 \mathrm{H}), 7.70(\mathrm{dd}, J=17.0,8.5 \mathrm{~Hz}, 2 \mathrm{H}), 7.48(\mathrm{t}, J=7.3 \mathrm{~Hz}, 2 \mathrm{H}), 7.24(\mathrm{~d}, J=7.8 \mathrm{~Hz}$, 1H), $6.92(\mathrm{~d}, J=8.9 \mathrm{~Hz}, 1 \mathrm{H}), 6.85(\mathrm{~s}, 1 \mathrm{H}), 3.63(\mathrm{~d}, J=22.7 \mathrm{~Hz}, 6 \mathrm{H}), 2.76(\mathrm{~s}, 2 \mathrm{H}), 2.06(\mathrm{~s}$, 2H), 1.91 (s, 2H). ${ }^{13} \mathrm{C}$ NMR (101 MHz, DMSO) $\delta 166.46,158.01,157.68,156.84,137.90$, $133.16,130.38,126.35,125.32,122.66,119.13,118.37,115.38,113.42,112.67,105.31$, 50.94, 50.64, 26.89, 19.77, 18.86. HR ESI $\left[\mathrm{M}+\mathrm{H}^{+}\right] \mathrm{m} / z$ 462.1690, calc. for $\mathrm{C}_{30} \mathrm{H}_{24} \mathrm{NO}_{4}{ }^{+}$ 462.17108. Compound $\mathbf{3 9}(50 \mathrm{mg}, 0.108 \mathrm{mmol})$ is dissolved in $25 \mathrm{~mL}$ of anhydrous $\mathrm{MeOH}$. $0.75 \mathrm{~mL}$ of acetyl chloride is added drop wise. The mixture is stirred and heated at $50{ }^{\circ} \mathrm{C}$ for $48 \mathrm{~h} .0 .3 \mathrm{~mL}$ of acetyl chloride is added and the mixture is kept at $50{ }^{\circ} \mathrm{C}$ for additional 
$24 \mathrm{~h}$. The solvent is evaporated under vacuum, the target compound $\mathbf{1 1}$ is isolated by flash column chromatography on silica gel using $\mathrm{CH}_{2} \mathrm{Cl}_{2}: \mathrm{MeOH}$ 90:10 for elution. Yield $46 \mathrm{mg}$, 90\%. ${ }^{1} \mathrm{H}$ NMR (400 MHz, DMSO) $\delta 11.50(\mathrm{~s}, 1 \mathrm{H}), 8.33(\mathrm{~d}, J=7.8 \mathrm{~Hz}, 1 \mathrm{H}), 7.97(\mathrm{t}, J=$ $7.3 \mathrm{~Hz}, 1 \mathrm{H}), 7.92-7.85(\mathrm{~m}, 1 \mathrm{H}), 7.73(\mathrm{dd}, J=12.5,8.5 \mathrm{~Hz}, 2 \mathrm{H}), 7.53$ (t, $J=7.9 \mathrm{~Hz}, 2 \mathrm{H})$, $7.31(\mathrm{~d}, J=7.9 \mathrm{~Hz}, 1 \mathrm{H}), 6.95-6.87(\mathrm{~m}, 2 \mathrm{H}), 3.71(\mathrm{~s}, 2 \mathrm{H}), 3.65(\mathrm{~s}, 2 \mathrm{H}), 3.56(\mathrm{~s}, 3 \mathrm{H}), 3.33$ (s, 2H), 2.78 (s, 2H), 2.08 (s, 2H), $1.92(\mathrm{~s}, 2 \mathrm{H}) .{ }^{13} \mathrm{C}$ NMR (101 MHz, DMSO) $\delta$ 201.26, $164.65,157.10,156.33,152.34,130.52,129.06,116.89,113.67,113.39,112.24,105.24$ 103.61, 52.59, 50.51, 19.55, 18.60. HR ESI $[M]^{+} \mathrm{m} / z$ 476.1858, calc. for $\mathrm{C}_{31} \mathrm{H}_{26} \mathrm{NO}_{4}{ }^{+}$ 476.1856.

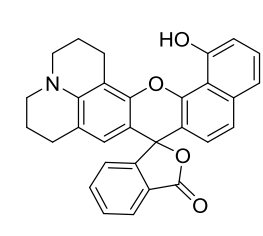

39

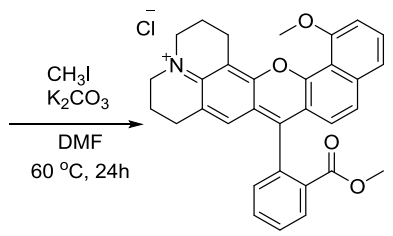

12

\subsection{Synthesis of 15-methoxy-9-(2-(methoxycarbonyl)phenyl)-1,2,3,5,6,7-}

\section{hexahydrobenzo[7,8]chromeno[2,3-f]pyrido[3,2,1-ij]quinolin-4-ium chloride, 12.}

Under Ar atm, compound 39 (25 mg, $0.054 \mathrm{mmol})$ is dissolved in $0.5 \mathrm{~mL}$ of anhydrous DMF, to this solution is added $\mathrm{K}_{2} \mathrm{CO}_{3}(22.5 \mathrm{mg}, 0.162 \mathrm{mmol})$ and $\mathrm{CH}_{3} \mathrm{I}(31 \mathrm{mg}$, $0.217 \mathrm{mmol}$ ). The mixture is heated at $60{ }^{\circ} \mathrm{C}$ for $24 \mathrm{~h}$, then allowed to cool down to room temperature. $2 \mathrm{~mL}$ of saturated $\mathrm{NH}_{4} \mathrm{Cl}$ is added to quench the reaction. The precipitate formed is filtered and washed with $0.5 \% \mathrm{NaOH}(2 \mathrm{~mL})$, then with water $(25 \mathrm{~mL})$. The title compound $\mathbf{1 2}$ is isolated by flash column chromatography on silica gel using $\mathrm{CH}_{2} \mathrm{Cl}_{2}: \mathrm{MeOH}$ 90:10 for elution. Yield: $16 \mathrm{mg}, 59 \% .{ }^{1} \mathrm{H} \mathrm{NMR}\left(400 \mathrm{MHz}, \mathrm{CDCl}_{3}\right) \delta 8.36$ $(\mathrm{dd}, J=7.9,1.1 \mathrm{~Hz}, 1 \mathrm{H}), 7.91-7.84(\mathrm{~m}, 1 \mathrm{H}), 7.82-7.72(\mathrm{~m}, 2 \mathrm{H}), 7.60(\mathrm{~d}, J=8.9 \mathrm{~Hz}$, 
1H), $7.50(\mathrm{~d}, J=7.9 \mathrm{~Hz}, 1 \mathrm{H}), 7.39(\mathrm{~d}, J=6.7 \mathrm{~Hz}, 1 \mathrm{H}), 7.20(\mathrm{~d}, J=8.0 \mathrm{~Hz}, 1 \mathrm{H}), 7.01(\mathrm{~d}, J$ $=8.9 \mathrm{~Hz}, 1 \mathrm{H}), 6.78(\mathrm{~s}, 1 \mathrm{H}), 4.22(\mathrm{~s}, 3 \mathrm{H}), 4.05-3.89(\mathrm{~m}, 2 \mathrm{H}), 3.84-3.69(\mathrm{~m}, 2 \mathrm{H}), 3.64(\mathrm{~s}$, $3 \mathrm{H}), 3.38(\mathrm{dd}, J=12.8,7.2 \mathrm{~Hz}, 2 \mathrm{H}), 2.95-2.74(\mathrm{~m}, 2 \mathrm{H}), 2.39-2.01(\mathrm{~m}, 4 \mathrm{H}) .{ }^{13} \mathrm{C} \mathrm{NMR}$ $\left(101 \mathrm{MHz}, \mathrm{CDCl}_{3}\right) \delta 165.59,158.81,156.53,154.52,153.32,138.73,134.59,133.58$, $132.36,131.54,130.76,130.56,129.86,129.77,126.66,125.79,123.21,120.99,118.11$, $117.86,114.58,108.74,106.16,56.79,52.74,52.32,52.05,28.08,20.40,20.18,19.65$. HR ESI [M] ${ }^{+} m / z$ 490.2026, calc. for $\mathrm{C}_{32} \mathrm{H}_{28} \mathrm{NO}_{4}{ }^{+} 490.2012$.

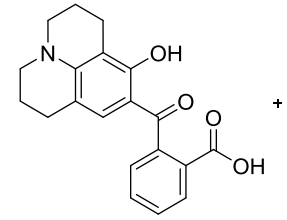

22

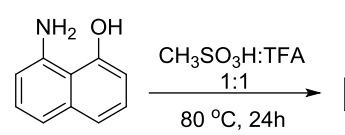

26

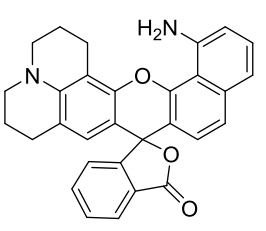

40
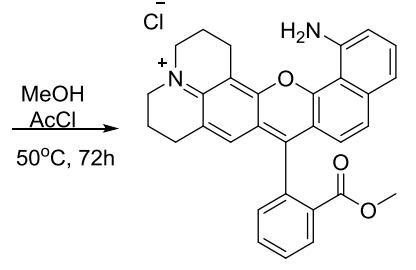

13

\subsection{Synthesis of 15-amino-9-(2-(methoxycarbonyl)phenyl)-1,2,3,5,6,7-}

hexahydrobenzo[7,8]chromeno[2,3-f]pyrido[3,2,1-ij]quinolin-4-ium chloride, 13.

Compound 22 (100 mg, $0.296 \mathrm{mmol}$ ) and compound 26 (71 mg, $0.444 \mathrm{mmol})$ are dissolved in $1.5 \mathrm{~mL}$ of methanesulfonic acid, then $1.5 \mathrm{~mL}$ of TFA is added. The mixture is stirred at $80{ }^{\circ} \mathrm{C}$ for $24 \mathrm{~h}$, then cooled down to room temperature. The mixture is poured into $50 \mathrm{~mL}$ of DI water, then neutralized by portion wise addition of $\mathrm{NaHCO}_{3}$, the green precipitate obtained is filtered and washed with DI water then air dried. The target compound is isolated by flash column chromatography on silica gel using $\mathrm{CH}_{2} \mathrm{Cl}_{2}: \mathrm{MeOH}$ 90:10, $80: 20$, and then $100 \% \mathrm{MeOH}$ to elute the last dark green band that corresponds to the target compound $\mathbf{4 0}$. The $\mathrm{MeOH}$ fraction is evaporated under vacuum, and the resulting solid is dissolved in a mixture of $\mathrm{CH}_{2} \mathrm{Cl}_{2}: \mathrm{MeOH} 90: 10$ and filtered trough a $0.22 \square \mathrm{m}$ filter to remove any dissolved silica. Yield $52 \mathrm{mg}, 39 \% .{ }^{1} \mathrm{H}$ NMR (400 MHz, DMSO) $\delta 8.01$ (d, 
$J=7.4 \mathrm{~Hz}, 1 \mathrm{H}), 7.79(\mathrm{td}, J=7.5,1.2 \mathrm{~Hz}, 1 \mathrm{H}), 7.72(\mathrm{td}, J=7.5,0.9 \mathrm{~Hz}, 1 \mathrm{H}), 7.37-7.25$ (m, 3H), $7.01(\mathrm{~d}, J=7.3 \mathrm{~Hz}, 1 \mathrm{H}), 6.81(\mathrm{~d}, J=6.7 \mathrm{~Hz}, 1 \mathrm{H}), 6.47(\mathrm{~d}, J=8.7 \mathrm{~Hz}, 1 \mathrm{H}), 6.38$ (s, 2H), $6.13(\mathrm{~s}, 1 \mathrm{H}), 3.23-3.10(\mathrm{~m}, 2 \mathrm{H}), 2.98(\mathrm{~d}, J=5.0 \mathrm{~Hz}, 1 \mathrm{H}), 2.02(\mathrm{~d}, J=2.9 \mathrm{~Hz}$, 2H), $1.85-1.75(\mathrm{~m}, 2 \mathrm{H}) .{ }^{13} \mathrm{C}$ NMR (101 MHz, DMSO) $\delta 168.83,153.34,152.90,149.78$, $149.33,147.24,146.83,145.90,145.24,144.55,136.55,135.57,130.04,128.76,126.35$, $124.61,124.19,123.96,123.31,118.66,115.22,115.01,112.06,110.74,110.65,108.55$, 106.10, 104.40, 84.50, 63.19, 49.20, 48.32, 26.76, 21.64, 21.13, 20.73, 18.57. HR ESI [M+ $\mathrm{H}]^{+} \mathrm{m} / z$ 461.1869, calc. for $\mathrm{C}_{30} \mathrm{H}_{25} \mathrm{~N}_{2} \mathrm{O}_{3}{ }^{+} 461.1859$. Compound 40 (20 mg, $0.043 \mathrm{mmol}$ ) is dissolved in $15 \mathrm{~mL}$ of anhydrous $\mathrm{MeOH} ; 0.75 \mathrm{~mL}$ of acetyl chloride is added drop wise. The mixture is stirred and heated at $50{ }^{\circ} \mathrm{C}$ for $48 \mathrm{~h}$; then $0.2 \mathrm{~mL}$ of acetyl chloride is added and the mixture is kept at $50{ }^{\circ} \mathrm{C}$ for additional $24 \mathrm{~h}$. The solvent is evaporated under vacuum. $21 \mathrm{mg}(100 \%)$ of the target compound 13 are obtained. ${ }^{1} \mathrm{H}$ NMR $(400 \mathrm{MHz}$, DMSO) $\delta 8.32(\mathrm{dd}, J=7.9,1.0 \mathrm{~Hz}, 1 \mathrm{H}), 7.96(\mathrm{td}, J=7.5,1.3 \mathrm{~Hz}, 1 \mathrm{H}), 7.92-7.84(\mathrm{~m}$, 1H), $7.69-7.63(\mathrm{~m}, 2 \mathrm{H}), 7.50(\mathrm{~d}, J=6.6 \mathrm{~Hz}, 1 \mathrm{H}), 7.30(\mathrm{~d}, J=7.6 \mathrm{~Hz}, 1 \mathrm{H}), 7.22(\mathrm{~d}, J=$ $7.9 \mathrm{~Hz}, 1 \mathrm{H}), 6.90-6.79(\mathrm{~m}, 2 \mathrm{H}), 3.73-3.61(\mathrm{~m}, 4 \mathrm{H}), 3.57(\mathrm{~s}, 1 \mathrm{H}), 3.27(\mathrm{~d}, J=5.9 \mathrm{~Hz}$, 2H), $2.82-2.74(\mathrm{~m}, 2 \mathrm{H}), 2.10(\mathrm{dd}, J=12.5,6.5 \mathrm{~Hz}, 2 \mathrm{H}), 1.91(\mathrm{~s}, 2 \mathrm{H}) .{ }^{13} \mathrm{C}$ NMR $(101$ $\left.\mathrm{MHz}, \mathrm{CDCl}_{3}\right) \delta 165.57,156.75,156.60,153.20,152.80,148.90,138.31,134.80,133.87$, $133.38,131.49,130.59,130.39,129.97,128.08,127.94,125.73,121.57,117.28,116.96$, $116.34,114.91,110.34,106.08,54.50,52.75,51.76,51.26,28.00,21.21,20.38,19.56 .$. HR ESI $\left[M^{+}\right] \mathrm{m} / \mathrm{z}$ 475.2029, calc. for $\mathrm{C}_{31} \mathrm{H}_{27} \mathrm{~N}_{2} \mathrm{O}_{3}{ }^{+} 475.2016$. 


\section{CHAPTER 3. SPECTRAL PROPERTIES}

The spectral properties of this series of probes (1-13) based upon seminaphthofluorescein, seminaphthorhodafluor, and seminaphthorhodamine scaffolds were screened for $\mathrm{pH}$ and solvent dependence. Absorption and fluorescence spectra of compounds containing ionizable hydroxyl groups (seminaphthofluorescein 1, and seminaphthorhodafluors 3,5 and 11) exhibited $\mathrm{pH}$ dependence over the physiological range as well as sensitivity to solvent composition. In aqueous solution, the hydroxyl forms of $\mathbf{1}, \mathbf{3}, \mathbf{5}$ and $\mathbf{1 1}$ were red-emitting while their conjugate bases exhibited near-infrared (NIR) fluorescence. Solvent dependence is at least partially attributable to differences in tautomer equilibria of the compounds in the various solvents. The observed $\mathrm{pH}$ and solvent sensitivity was removed through derivatization. Methoxy-functionalized analogs $(\mathbf{2}, \mathbf{4}, \mathbf{6}$ and 12) displayed relatively bright red fluorescence and were independent of variations in $\mathrm{pH}$ and solvent composition. Replacing the hydroxyl with amines generated a series of NIR-emitting seminaphthorhodamines $(\mathbf{9}, 10$ and 13). The spectral properties of 9,10 and 13 were $\mathrm{pH}$ independent and only modestly dependent on solvent. Transposition of thy hydroxyl and amine functionalities in seminathorhodafluors $\mathbf{3}$ and $\mathbf{5}$ generated compounds 7 and 8. Transposition lowered the $\mathrm{p} K_{\mathrm{a}}$ resulting in spectral properties that were not $\mathrm{pH}$ dependent in the physiological range. 


\section{1 pH-dependent Spectral Properties of Dual-emitting Seminaphthofluorescein}

and Seminaphthorhodafluors.

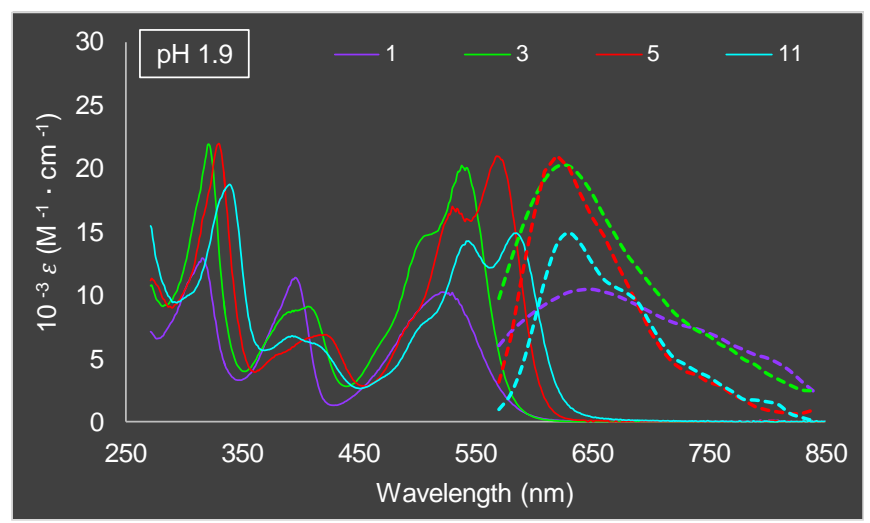

Figure 3.1 Absorption spectra (solid lines) and normalized fluorescence emission spectra (dash lines) of pH-dependent 1, 3, 5 and 11 in acidic solution (pH 1.9, HCl). Red emitting species were excited at $480 \mathrm{~nm}$ or $510 \mathrm{~nm}$. Emission spectra are normalized to their their corresponding absorption peaks.
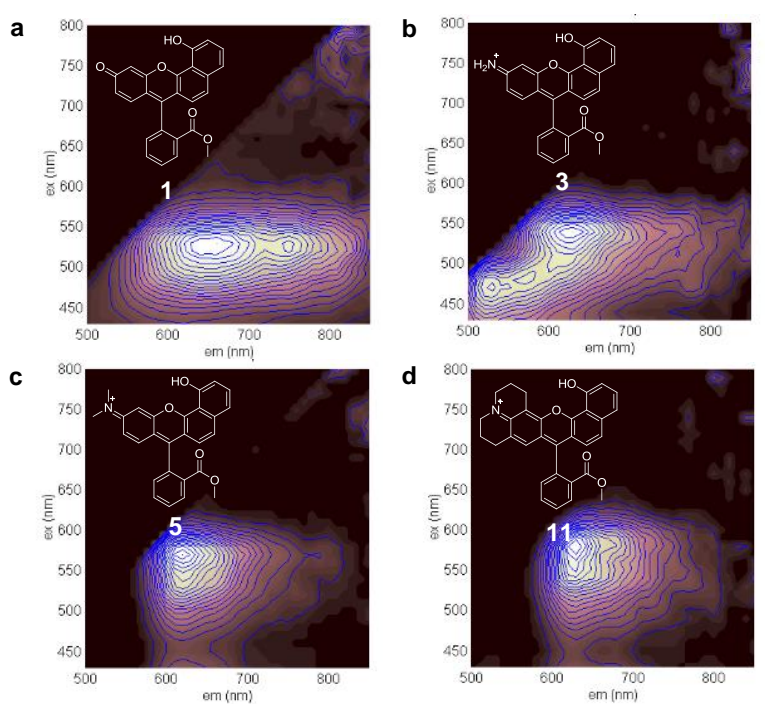

Figure 3.2 Excitation Emission Matrices, of pH-dependent 1 (a), 3 (b), 5 (c) and 11 (d) in acidic solution. The color scale of EEMs are normalized to the maximum of each plot.

The spectral properties of compounds $\mathbf{1}, \mathbf{3}, \mathbf{5}$, and $\mathbf{1 1}$ are $\mathrm{pH}$ sensitive as a result of the hydroxyl groups with $\mathrm{p} K_{\mathrm{a}}$ values in the physiological range. In acid, the hydroxyl forms 
of the compounds display structured absorption peaks with maxima ranging from 530 to $585 \mathrm{~nm}$, modest Stokes shifts, and fluorescence emission maxima between 600 and 624 nm.

Table 3.1 Tabulated spectral properties of $\mathrm{pH}$-dependent $1,3,5$ and 11 in acidic solution.

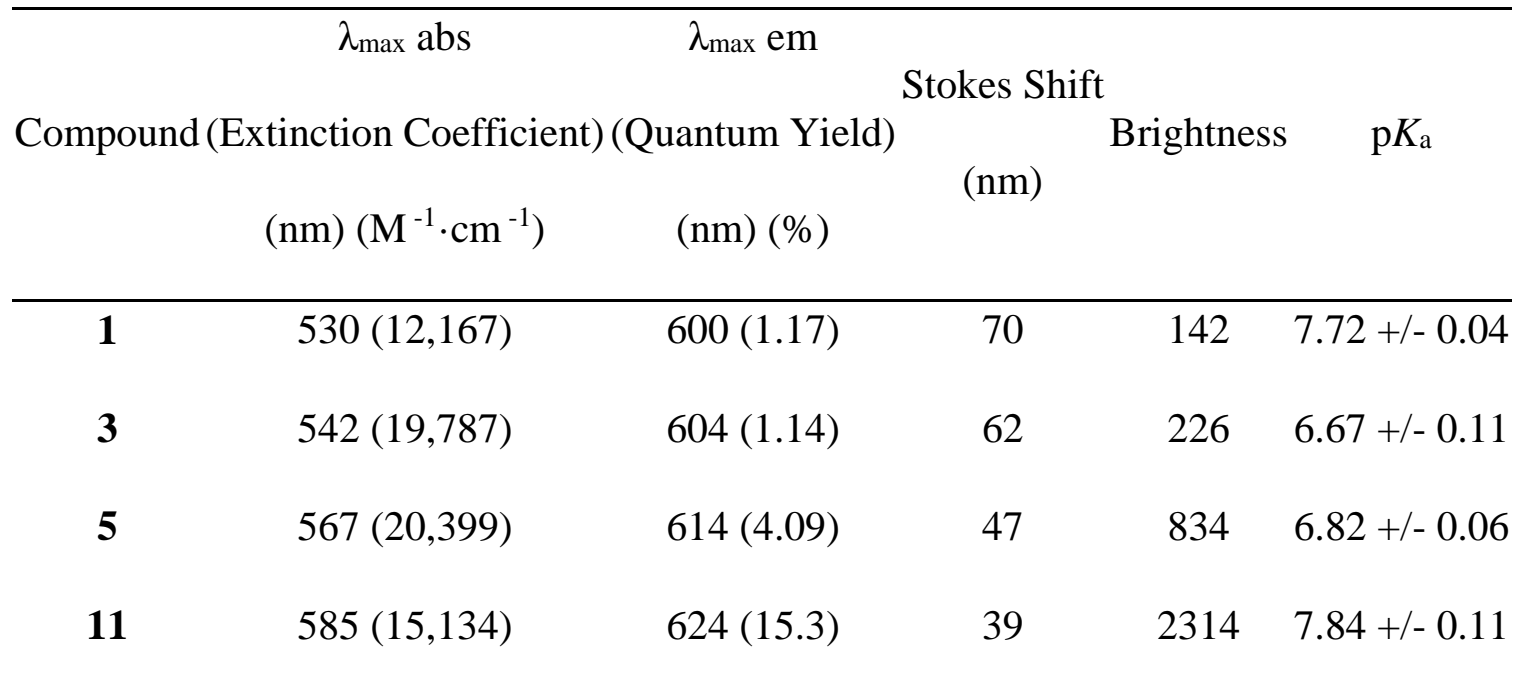

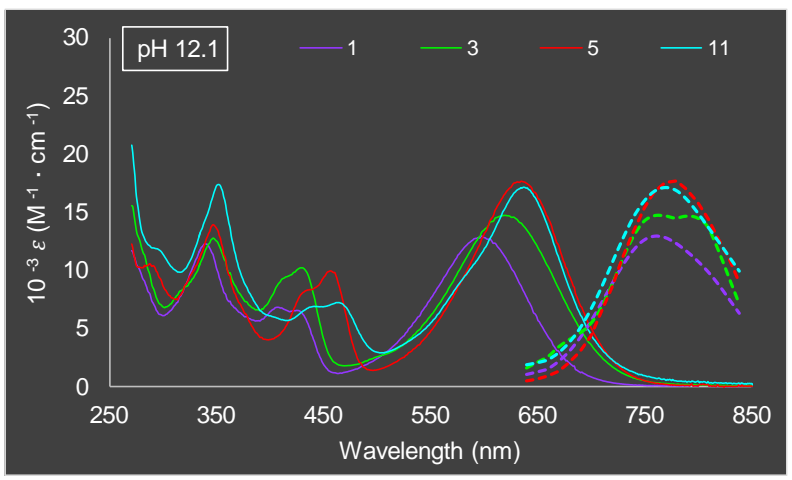

Figure 3.3 Absorption spectra (solid lines) and normalized fluorescence emission spectra (dash lines) of pH-dependent 1, 3, 5 and 11 in basic solution (pH 12.1, $\mathrm{NaOH}$ ). NIR emitting species in were excited at $630 \mathrm{~nm}$. Emission spectra are normalized to their corresponding absorption peaks. 

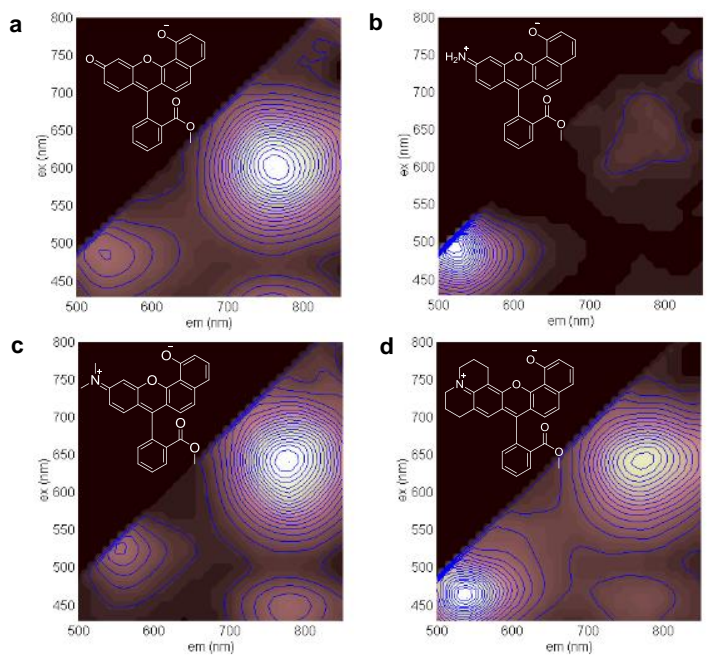

Figure 3.4 Excitation Emission Matrices, of pH-dependent 1 (a), 3 (b), 5 (c) and 11 (d) in basic solution. The color scale of EEMs are normalized to the maximum of each plot.

Table 3.2 Tabulated spectral properties of $\mathrm{pH}$-dependent $1,3,5$ and 11 in basic solution.

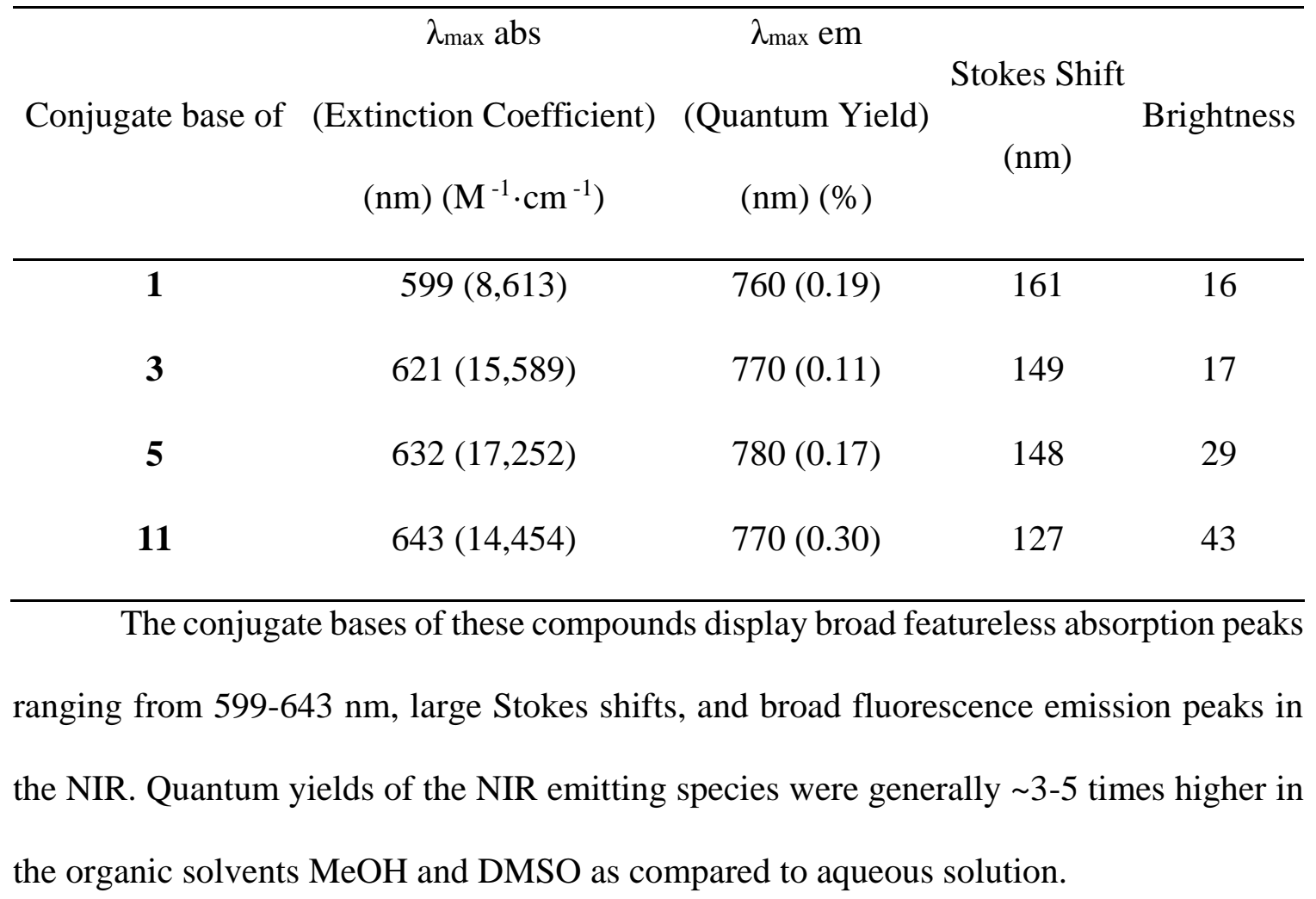



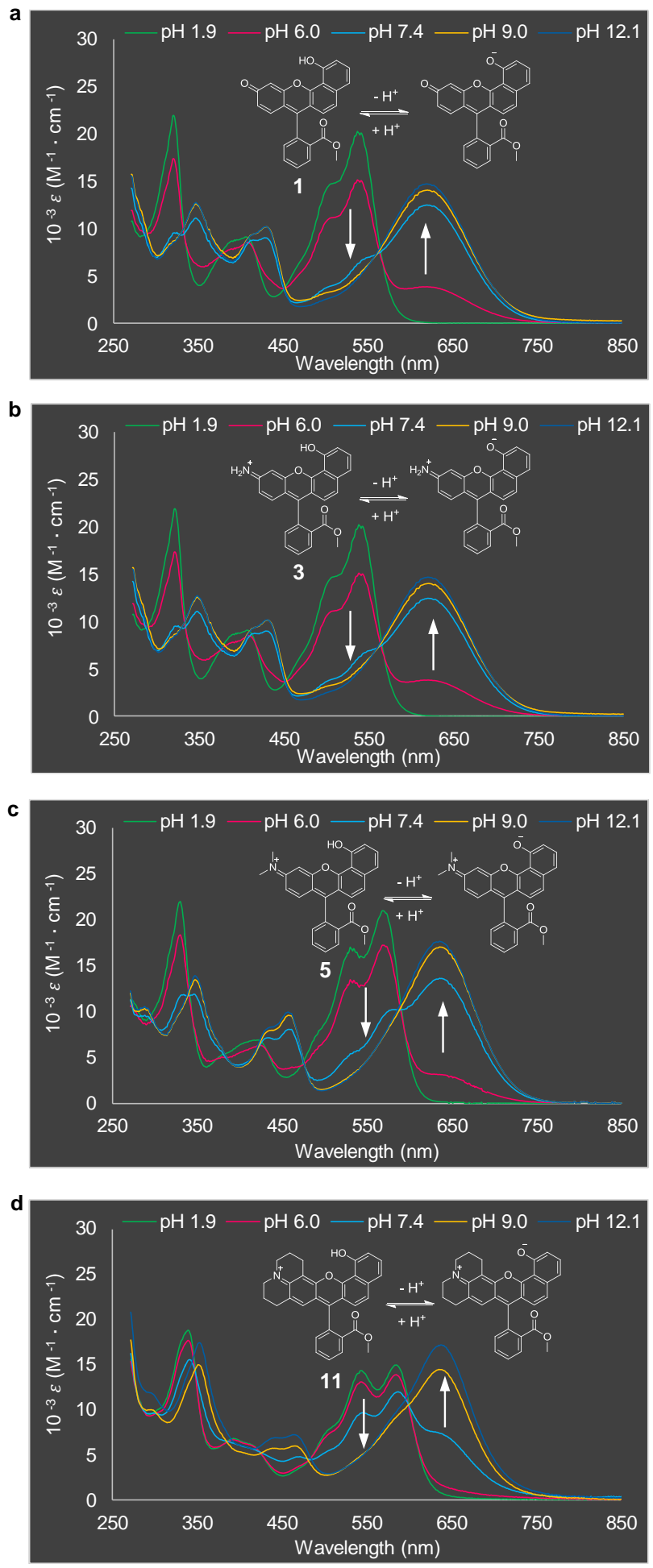

Figure 3.5 Absorption spectra as a function of $\mathrm{pH}$ for $\mathrm{pH}$-dependent 1 (a), 3 (b), 5 (c) and 11 (d). 

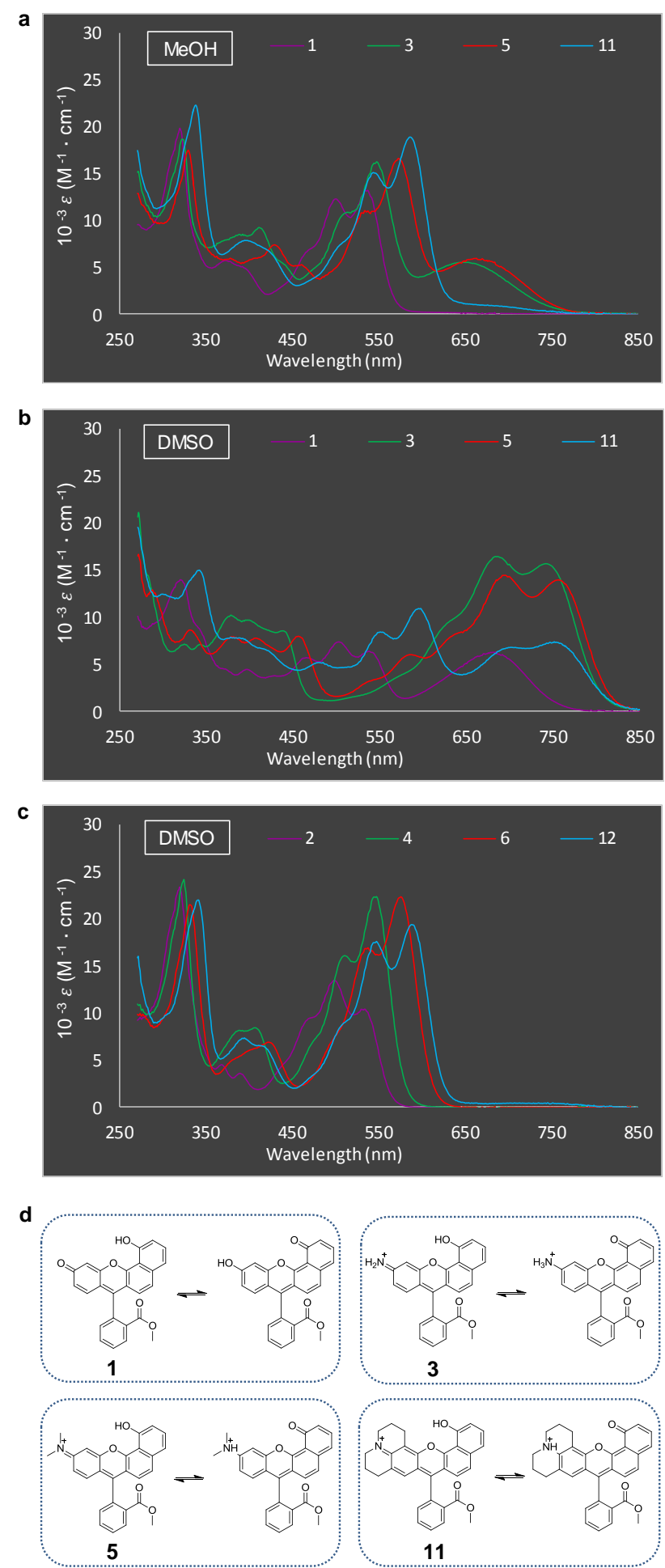

Figure 3.6 Absorption spectra of 1, 3, 5 and 11 as a function of solvents including MeOH and DMSO. 
Ratiometric absorption spectra with $\mathrm{p} K_{\mathrm{a}}$ values in the physiological range were observed for $\mathbf{1}, \mathbf{3}, \mathbf{5}$ and $\mathbf{1 1}$. Well defined isosbestic points indicate spectral changes result from acid-base equilibria between two species. In aqueous solution at low $\mathrm{pH}$, a single tautomer with hydroxyls on the annulated ring dominate. Absorptions from both tautomers are apparent in organic solvents. Long wavelength tautomers are more pronounced in $\mathbf{3}$ and 5 as compared to $\mathbf{1}$ and 11; and in DMSO as compared to $\mathrm{MeOH}$. Methyl ether derivatives 2, 4, 6 and 12 approximate naphthol tautomers, existing as single species similar to short wavelength tautomers of $\mathbf{1}, \mathbf{3}, \mathbf{5}$, and $\mathbf{1 1}$ in organic solvents.

\section{2 pH-independent Spectral Properties of Red-emitting Methyl Ether Derivatives.}

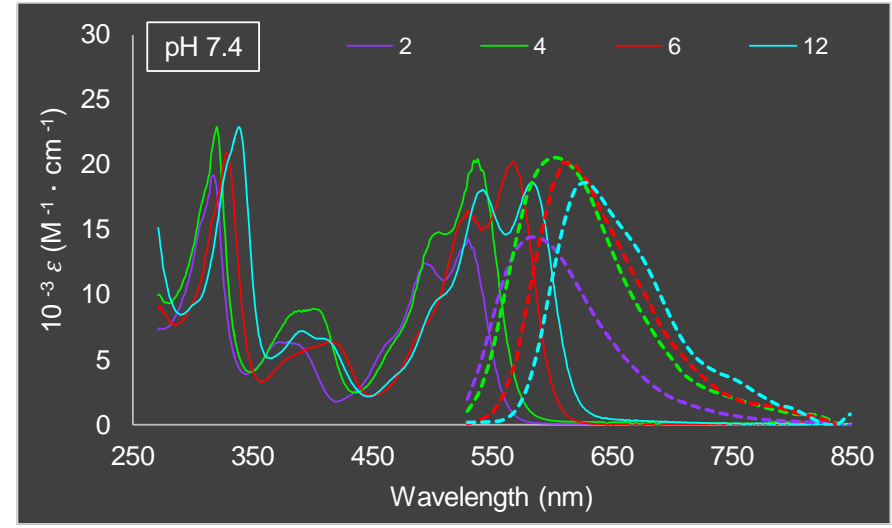

Figure 3.7 Absorption spectra (solid lines) and normalized fluorescence emission spectra (dash lines) of pH-independent 2, 4, 6 and 12 in pH 7.4 buffer. Red emitting species were excited at $480 \mathrm{~nm}$ or $510 \mathrm{~nm}$. Emission spectra are normalized to their corresponding absorption peaks. 

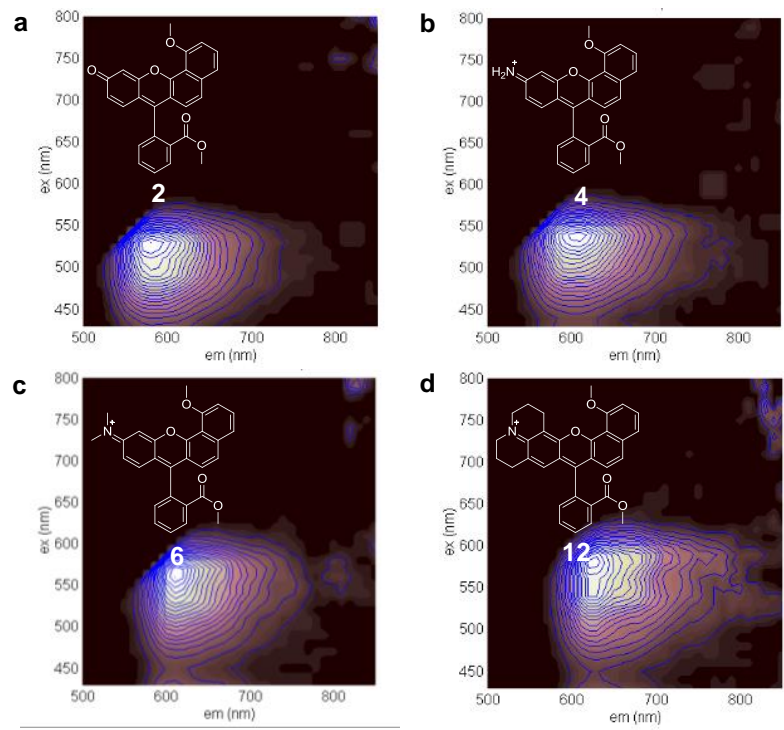

Figure 3.8 Excitation Emission Matrices of pH-independent 2 (a), 4 (b), 6 (c) and 12 (d) in pH 7.4 buffer. The color scale of EEMs are normalized to the maximum of each plot.

Table 3.3 Tabulated spectral properties of pH-independent 2, 4, 6 and 12 in basic solution.

\begin{tabular}{ccccc}
\hline & \multicolumn{1}{c}{$\lambda_{\max }$ abs } & $\lambda_{\max }$ em & Stokes shift & \\
Compound & $($ Extinction Coefficient $)$ & $($ Quantum Yield $)$ & Brightness \\
& $(\mathrm{nm})\left(\mathrm{M}^{-1} \cdot \mathrm{cm}^{-1}\right)$ & $(\mathrm{nm})(\%)$ & \\
\hline $\mathbf{2}$ & $530(15,610)$ & $580(46.49)$ & 50 & 7257 \\
$\mathbf{4}$ & $538(21,742)$ & $596(34.42)$ & 58 & 7484 \\
$\mathbf{6}$ & $568(22,470)$ & $606(9.32)$ & 38 & 2094 \\
& $582(17,764)$ & $622(11.38)$ & 40 & 2022 \\
& & & & \\
\hline
\end{tabular}



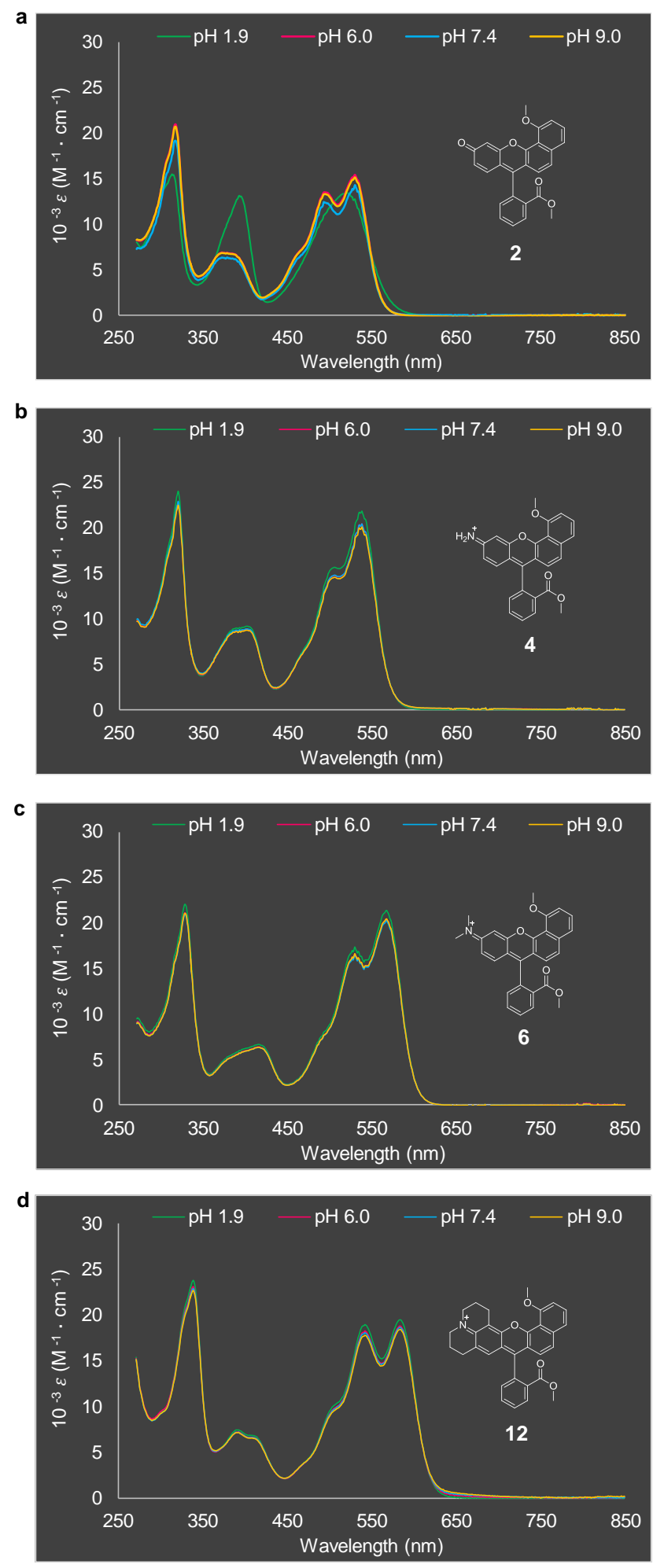

Figure 3.9 Absorption spectra as a function of $\mathbf{p H}$ for methyl ether derivatives 2 (a), 4 (b), 6 (c) and 12 (d). 

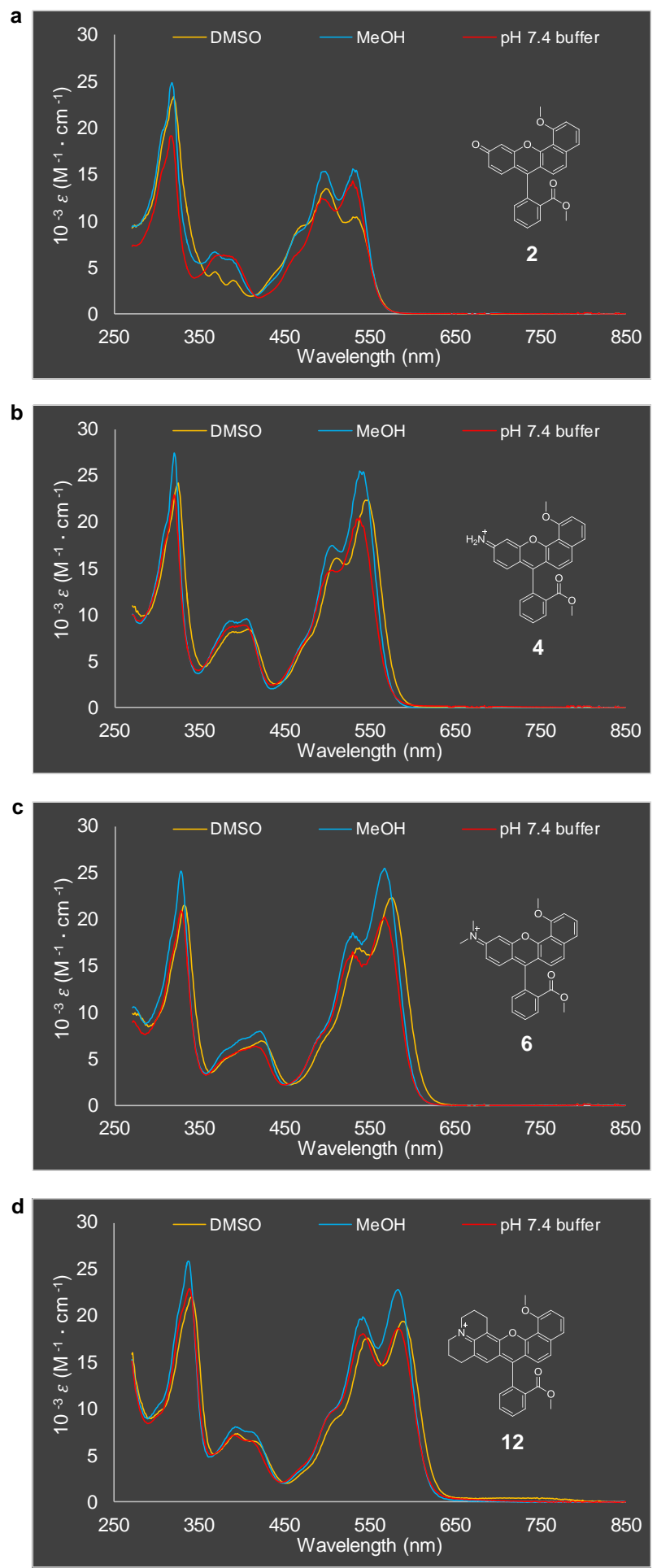

Figure 3.10 Absorption spectra as a function of solvents including DMSO, MeOH and pH 7.4 phosphate buffer for methyl ether derivatives 2 (a), 4 (b), 6 (c) and 12 (d). 
3.3 pH-independent Spectral Properties of NIR-emitting Seminaphthorhodamines.

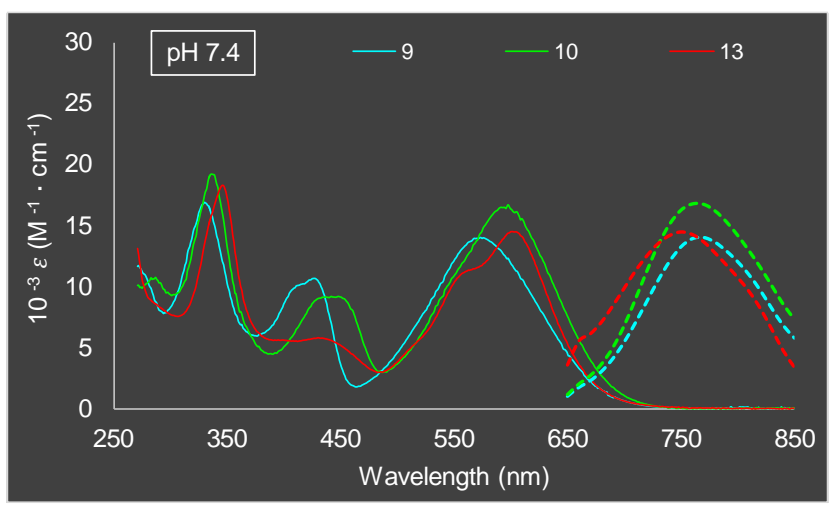

Figure 3.11 Absorption spectra (solid lines) and normalized fluorescence emission spectra (dash lines) of pH-independent 9, 10 and 13 in pH 7.4 buffer. NIR emitting species were excited at $630 \mathrm{~nm}$. Emission spectra are normalized to their corresponding absorption peaks.

a
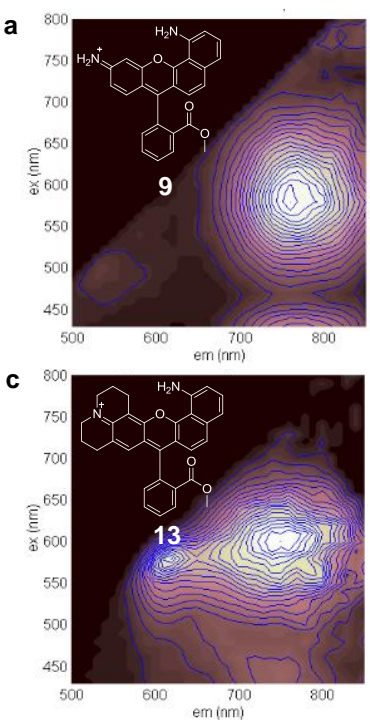

b

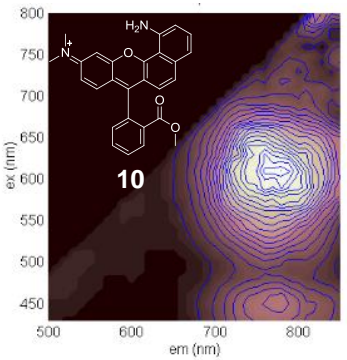

Figure 3.12 Excitation Emission Matrices of pH-independent 9 (a), 10 (b), and 13 (c) in pH 7.4 buffer. The color scale of EEMs are normalized to the maximum of each plot. 
Table 3.3 Tabulated spectral properties of $\mathrm{pH}$-independent 2, 4, 6 and 12 in basic solution.

\begin{tabular}{|c|c|c|c|c|}
\hline Compound & $\begin{array}{c}\lambda_{\max } \text { abs } \\
\text { (Extinction Coefficient) } \\
(\mathrm{nm})\left(\mathrm{M}^{-1} \cdot \mathrm{cm}^{-1}\right)\end{array}$ & $\begin{array}{c}\lambda_{\max } \mathrm{em} \\
\text { (Quantum Yield) } \\
(\mathrm{nm})(\%)\end{array}$ & $\begin{array}{c}\text { Stokes Shift } \\
(\mathrm{nm})\end{array}$ & Brightness \\
\hline 9 & $576(13,872)$ & $760(0.18)$ & 184 & 25 \\
\hline 10 & $598(17,066)$ & $770(0.20)$ & 172 & 34 \\
\hline 13 & $601(12,808)$ & $740(0.66)$ & 139 & 85 \\
\hline
\end{tabular}

Replacing the ionizable hydyroxyl groups with a methyl ether (compounds $2,4,6$, 12) removes both the $\mathrm{pH}$ and tautomeric equilibria of compounds $1, \mathbf{3}, \mathbf{5}, \mathbf{1 1}$, thus approximating naphthol tautomers in a range of solvents and $\mathrm{pH}$ values. Absorption spectra of the methyl ether derivatives are nearly identical to their corresponding hydroxyl analogs. Emission wavelengths of the methyl ethers remain in the orange/red region. Quantum yields of the methyl ethers range from $\sim 10-45 \%$ and are generally improved as compared to their hydroxyl analogs (improvements of $\sim 40$ fold for $\mathbf{2}, 30$ fold for $\mathbf{4}$ and more than 2 fold for 6). No $\mathrm{pH}$ or tautomeric equilibria are observed for the methyl ether derivatives. There was no significant change in wavelength upon changing solvents from DMSO to $\mathrm{MeOH}$ to aqueous solution. 

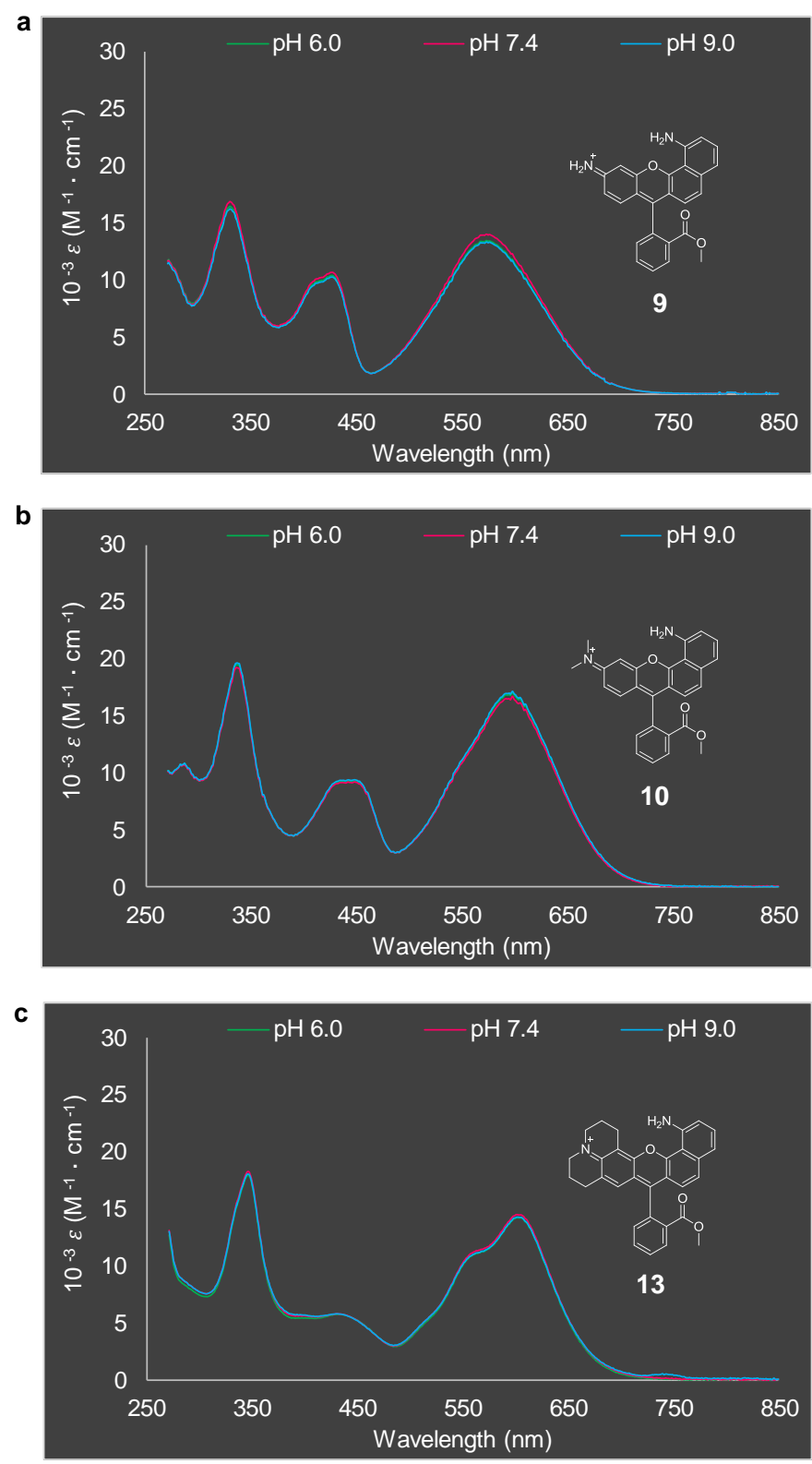

Figure 3.13 Absorption spectra as a function of pH-independent seminaphthorhodamines 9 (a), 10 (b) and 13 (c). 

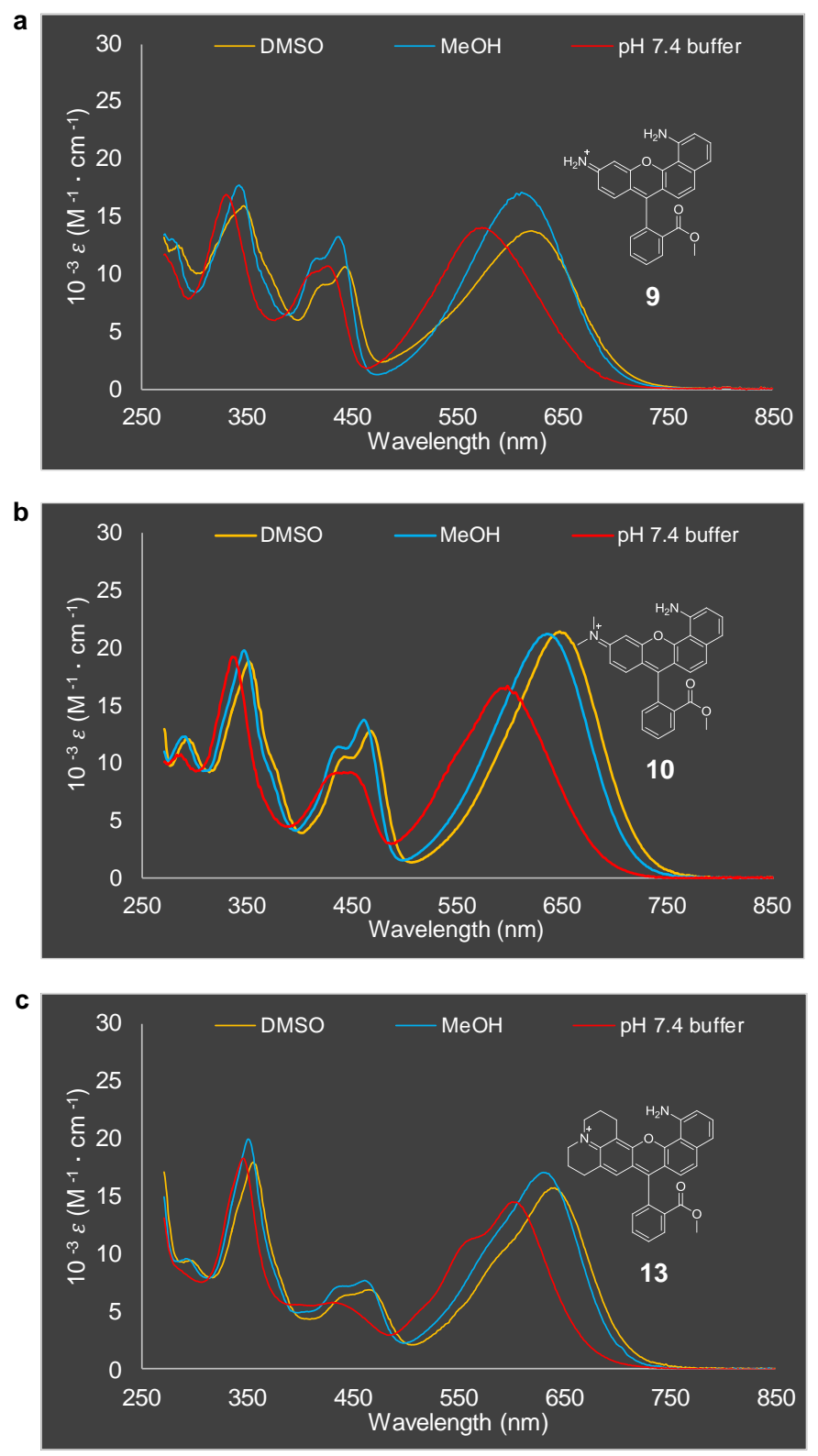

Figure 3.14 Absorption spectra as a function of solvents including DMSO, MeOH and pH 7.4 phosphate buffer for pH-independent seminaphthorhodamines 9 (a), 10 (b) and 13 (c).

Replacing the hydroxyl group with an $\mathrm{NH}_{2}$ group (compounds 9,10 and 13) provides another method to remove the $\mathrm{pH}$ dependence while maintaining the long 
wavelength NIR emission observed in the conjugate bases of compounds $\mathbf{3 , 5}$, and $\mathbf{1 1}$ in a range of $\mathrm{pH}$ values for the resulting seminaphthorhodamines. The seminaphthorhodamines show no sensitivity to $\mathrm{pH}$ over a wide range encompassing physiological $\mathrm{pH}$. Emission maxima are all greater than $740 \mathrm{~nm}$ with large Stokes shifts. The seminaphthorhodamines are approximately twice as bright as the corresponding long wavelength emissions observed for the conjugate bases of compounds 3, 5 and 11. Quantum yields of the NIR emitting species were generally $~ 3-5$ times higher in the organic solvents $\mathrm{MeOH}$ and DMSO as compared to aqueous solution. No $\mathrm{pH}$ equilibria are observed for the seminaphthorhodamine derivatives. Seminaphthorhodamines 9, $\mathbf{1 0}$ and $\mathbf{1 3}$ display moderate sensitivity to polarity with the longest wavelengths in DMSO and the shortest in aqueous solution.

\section{4 pH-dependent Spectral Poperties of Tansposed Sminaphthorhodafluors}

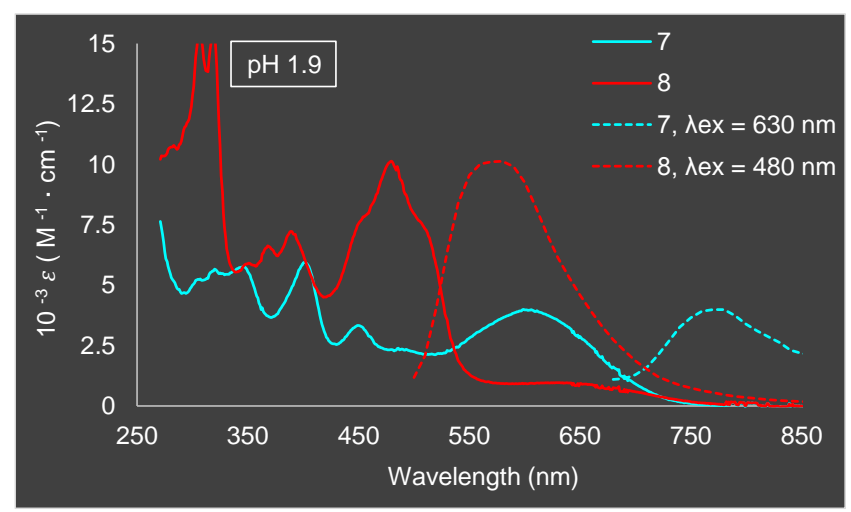

Figure 3.15 Absorption spectra (solid lines) and normalized fluorescence emission spectra (dash lines) of conjugate acids of 7 and 8 in acidic solution (pH 1.9, HCl). Red emitting species were excited at $480 \mathrm{~nm}$, and NIR emitting species were excited at $630 \mathrm{~nm}$. Emission spectra are normalized to their corresponding absorption peaks. 

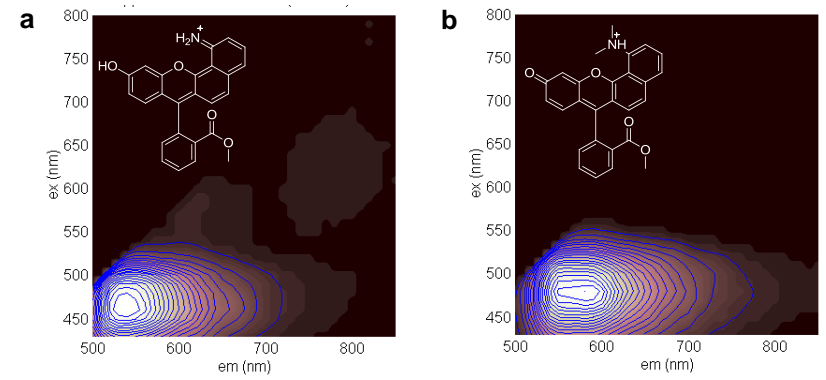

Figure 3.16 Excitation Emission Matrices of conjugate acids of 7 (a), and 8 (b) in acidic solution (pH 1.9, HCl). The color scale of EEMs are normalized to the maximum of each plot.

Table 3.5 Tabulated spectral properties of the conjugate acids of 7 and 8 in acidic solution.

\begin{tabular}{ccccc}
\hline Conjugate acid of & $\lambda_{\max }$ abs & $\lambda_{\max }$ em & Stokes Shift & \\
& $($ Extinction Coefficient $)$ & $(\mathrm{nm})$ & $(\mathrm{nm})$ & $\mathrm{p} K_{\mathrm{a}}$ \\
& $(\mathrm{nm})\left(\mathrm{M}^{-1} \cdot \mathrm{cm}^{-1}\right)$ & & & \\
\hline $\mathbf{7}$ & $598(3,996)$ & 770 & 172 & $4.99+/-0.13$ \\
$\mathbf{8}$ & $480(10,132)$ & 580 & 100 & $4.36+/-0.04$ \\
\hline
\end{tabular}




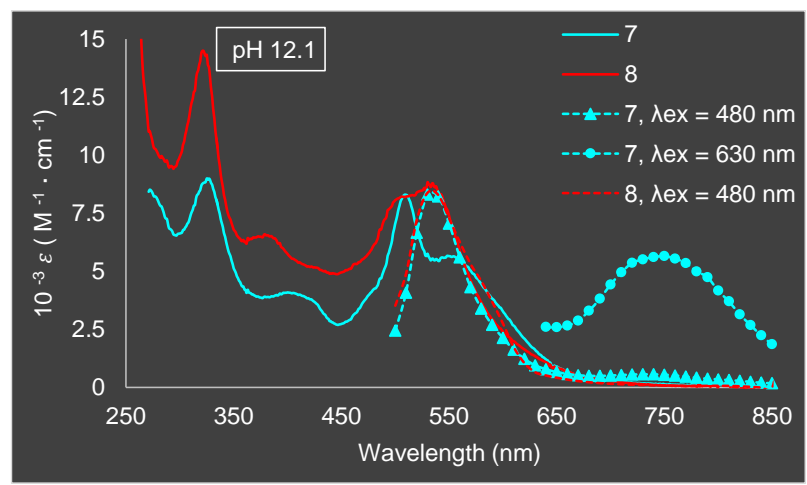

Figure 3.17 Absorption spectra (solid lines) and normalized fluorescence emission spectra (dash lines) of 7 and 8 in basic solution (pH 12.1, NaOH). Red emitting species were excited at $480 \mathrm{~nm}$, and NIR emitting species were excited at $630 \mathrm{~nm}$. Emission spectra are normalized to their corresponding absorption peaks.
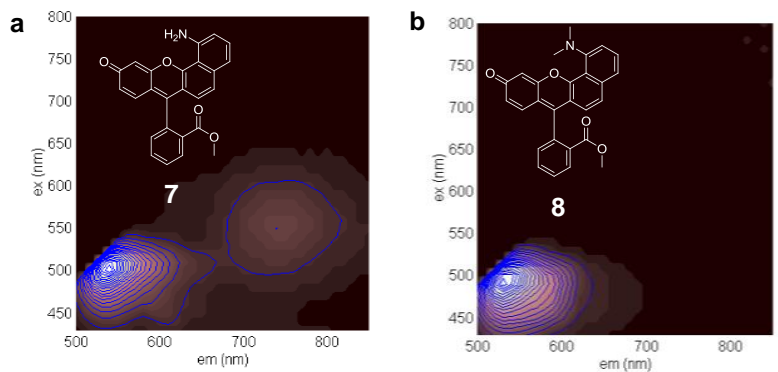

Figure 3.18 Excitation Emission Matrices of 7 (a), and 8 (b) in basic solution (pH 12.1, NaOH). The color scale of EEMs are normalized to the maximum of each plot. 
Table 3.6 Tabulated spectral properties of 7 and 8 in basic solution.

\begin{tabular}{cccc}
\hline Compound & $\begin{array}{c}\lambda_{\max } \text { abs } \\
(\text { Extinction Coefficient }) \\
(\mathrm{nm})\left(\mathrm{M}^{-1} \cdot \mathrm{cm}^{-1}\right)\end{array}$ & $\begin{array}{c}\lambda_{\max } \mathrm{em} \\
(\mathrm{nm})\end{array}$ & $\begin{array}{c}\text { Stokes Shift } \\
(\mathrm{nm})\end{array}$ \\
\hline $\mathbf{7}$ & $509(8,300)$ & 530 & 21 \\
$\mathbf{7}$ & $549(5,664)$ & 750 & 201 \\
$\mathbf{8}$ & $530(8,834)$ & 530 & 21 \\
\hline
\end{tabular}

Compared to seminaphthorhodafluors $\mathbf{3}$ and $\mathbf{5}$, the hydroxyl and amine groups are transposed in compounds $\mathbf{7}$ and $\mathbf{8}$. Seminaphthorhodafluors $\mathbf{3}$ and $\mathbf{5}$ were isolated as acidic salts with $\mathrm{p} K_{\mathrm{a}}$ values in the physiological range, resulting in ratiometric spectral properties (short wavelength absorption and emission for the acids with long wavelength absorption and emission for the conjugate bases). The transposed compounds were isolated as neutral species, having $\mathrm{p} K_{\mathrm{a}}$ values approximately 2 units lower, thus displaying no sensitively to $\mathrm{pH}$ over the physiological range. At physiological $\mathrm{pH}$ and in organic solvents, both $\mathbf{7}$ and 8 displayed an absorption maxima near $525 \mathrm{~nm}$. Protonation lead to a long wavelength absorption near $600 \mathrm{~nm}$ for 7 and short wavelength absorption near $450 \mathrm{~nm}$ for 8 . Compound $\mathbf{8}$ was short wavelength absorbing and emitting as both the base and conjugate acid with no long wavelength species observed. Interestingly, 7 displayed dual emission as both the base and conjugate acid. These dual emissions are attributed to different tautomeric forms exhibiting less strained geometries. 


\section{CHAPTER 4. PROBE IN VITRO STUDIES}

\subsection{Structures and Calculated Physicochemical Properties Summary of 2, 12 and 13.}

Compounds 2, 12 and $\mathbf{1 3}$ are representative of three classes of benzo[c]xanthenes and were chosen as candidates for initial in vitro and in vivo screening for pancreas and PDAC targeting based on their predicted physiochemical properties, $\mathrm{pH}$ independence, and attractive spectral properties.

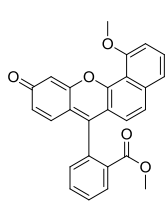

2

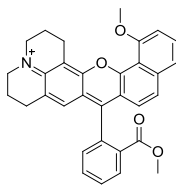

12

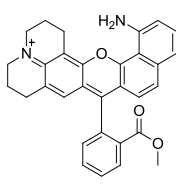

13
$\mathrm{MW}=410.42 \mathrm{~g} / \mathrm{mol}$

$\log \mathrm{D}=4.49$

Formal charge $=0$

$\mathrm{H}$-bond donors $=0$

$\mathrm{H}$-bond acceptors $=5$

Polar surface area $=61.83 \AA^{2}$

Dipole moment $=6.67$ Debye

$\mathrm{MW}=490.57 \mathrm{~g} / \mathrm{mol}$

$\log D=1.91$

Formal charge $=+1$

$\mathrm{H}$-bond donors $=0$

$\mathrm{H}$-bond acceptors $=4$

Polar surface area $=47.77 \AA^{2}$

Dipole moment $=6.52$ Debye

$\mathrm{MW}=475.56 \mathrm{~g} / \mathrm{mol}$

$\log D=1.24$

Formal charge $=+1$

$\mathrm{H}$-bond donors $=2$

$\mathrm{H}$-bond acceptors $=4$

Polar surface area $=64.56 \AA^{2}$

Dipole moment $=6.78$ Debye
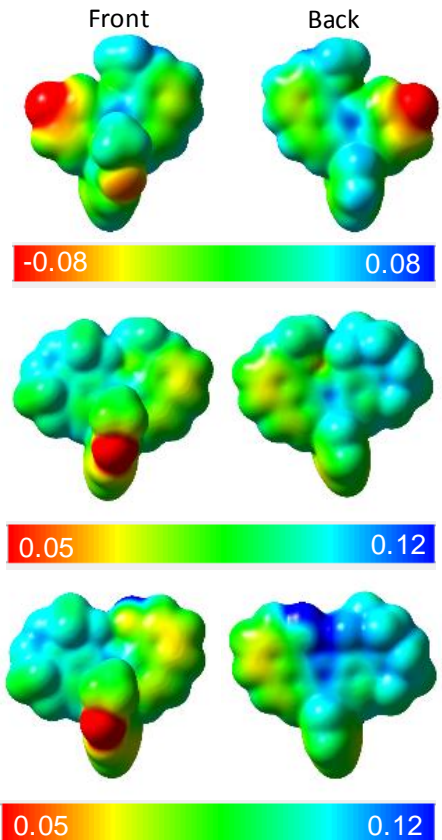

Figure 4.1 Structures and calculated physicochemical properties summary of 2, 12 and 13.

These dyes (Fig.4.1) represent three classes of benzo[c]xanthenes: seminaphthofluorescein (2), seminaphthorhodafluor (12), and seminaphthorhodamine (13). Color-mapped surfaces show the molecular electrostatic potential (blue is positive, green is neutral, and red is negative). Analysis of their calculated "drug-like" properties 
reveals potential biological activity differences in response to structural variations in the molecular design.

\subsection{In Vitro Cell Viability of Compounds 2, 12 and 13.}

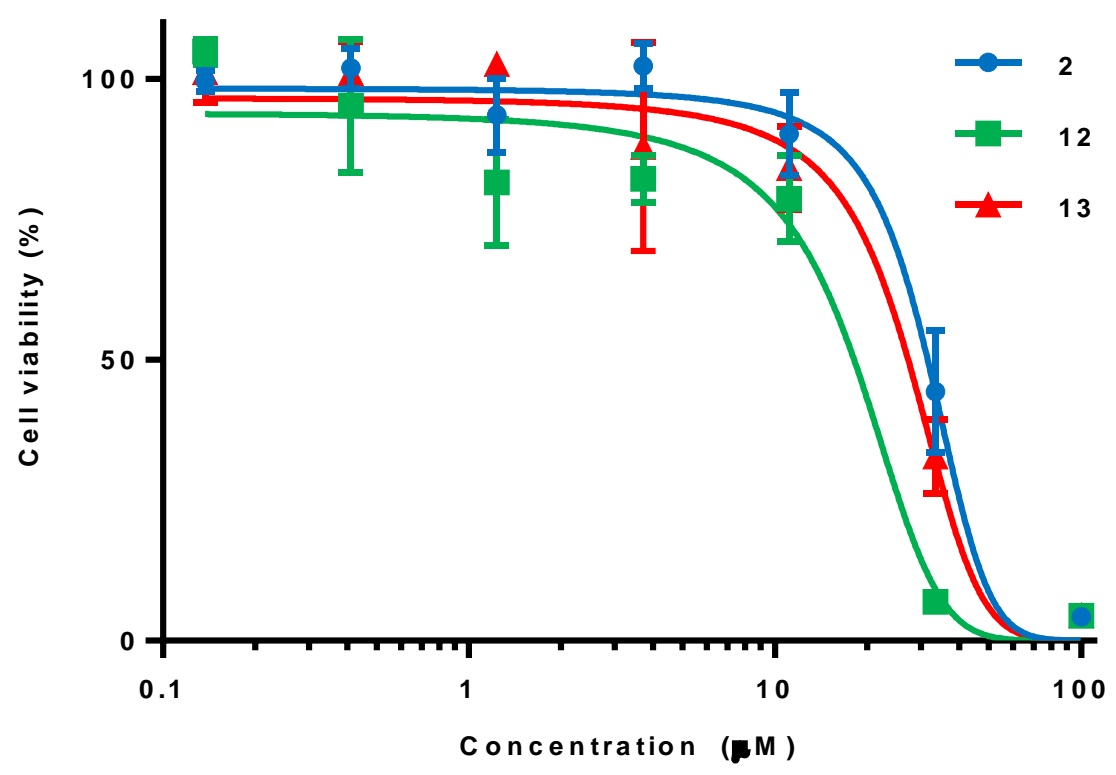

Figure 4.2 Cell viability of compounds 2, 12, and 13 in Capan-1 cells.

In vitro cell viability (Fig. 4.2) was assessed in the presence of compounds $\mathbf{2}, \mathbf{1 2}$ and 13 in Capan-1 cells, a representative PDAC cell line. The cytotoxicity studies demonstrated that compound 2 was the least toxic (IC50 $30.08 \mu \mathrm{M}$ ) followed by compounds $13\left(\mathrm{IC}_{50} 26.08 \mu \mathrm{M}\right)$ and $12\left(\mathrm{IC}_{50} 17.79 \mu \mathrm{M}\right)$. 


\subsection{In Vitro Time-dependent Fluorophore Uptake of Compounds 2, 12 and 13.}

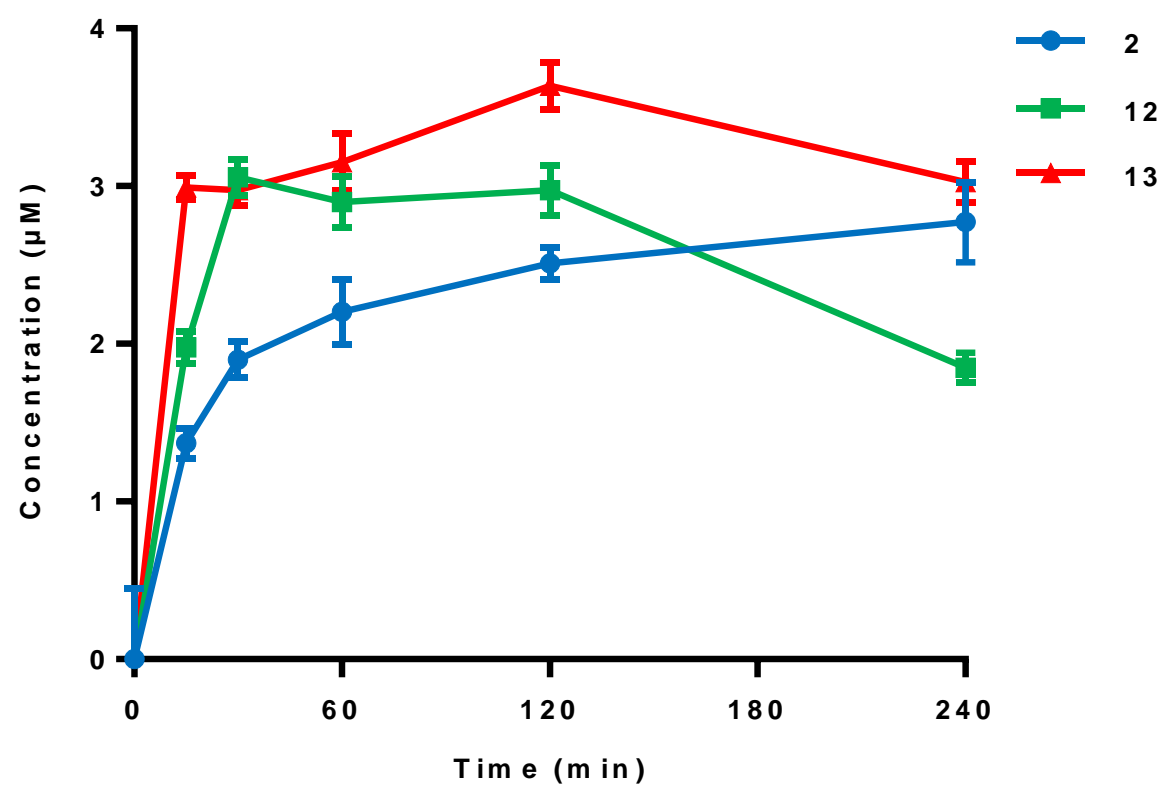

Figure 4.3 Cellular uptake of compounds 2, 12, and 13 in Capan-1 cells.

In vitro time-dependent fluorophore uptake was investigated in PDAC cells (Fig.

4.3). Each fluorophore exhibited similar kinetics, demonstrating uptake within 30 min of fluorophore application. Compound $\mathbf{1 3}$ exhibited the greatest uptake, and $\mathbf{2}$ the lowest during this period. We attribute this to the favorable membrane interactions of the cationic fluorophores 12 and $\mathbf{1 3}$ as compared to neutral 2. After $30 \mathrm{~min}$, all compounds showed a relatively slow increase in uptake that lasted for up to $2 \mathrm{~h}$. Compounds $\mathbf{1 2}$ and $\mathbf{1 3}$ began clearing from the cells after $2 \mathrm{~h}$. 


\subsection{Subcellular Localization of Compounds 2, 12, and 13.}
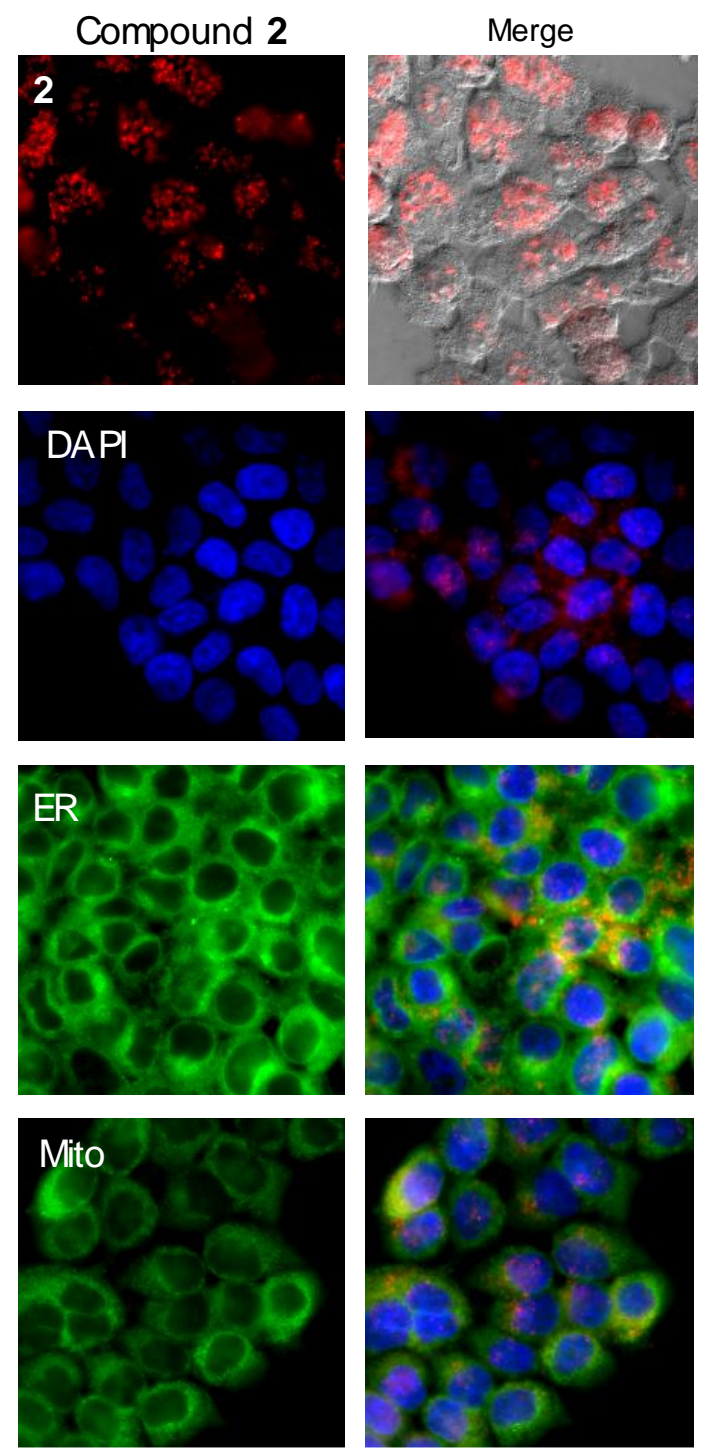

Figure 4.4 Subcellular localization of compounds 2 in Capan-1 cells. Fluorescence images containing synthesized fluorophores are labeled as 2 (red). Images of subcellular organelles stained with commercial fluorescent trackers are labeled as DAPI (blue), ER (green) or Mito (green). The merge columns show images of (top) phase contrast of compound $\mathbf{2}$, followed successively below by colocalization of DAPI + compound $\mathbf{2}$, colocalization of DAPI + ER + compound 2, and colocalization of DAPI + Mito + compound 2. 

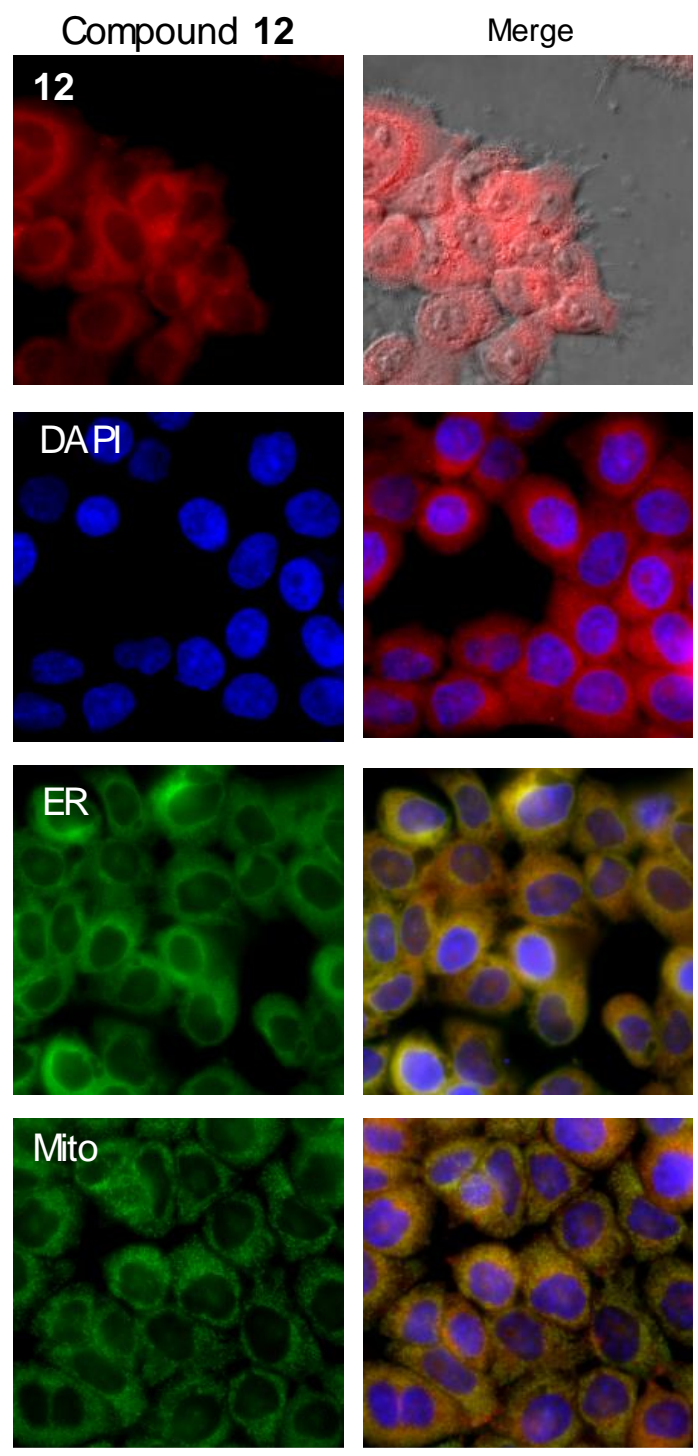

Figure 4.5 Subcellular localization of compounds 12 in Capan-1 cells. Fluorescence images containing synthesized fluorophores are labeled as 12 (red). Images of subcellular organelles stained with commercial fluorescent trackers are labeled as DAPI (blue), ER (green) or Mito (green). The merge columns show images of (top) phase contrast of compound 12, followed successively below by colocalization of DAPI + compound 12, colocalization of DAPI + ER + compound 12, and colocalization of DAPI + Mito + compound 12. 

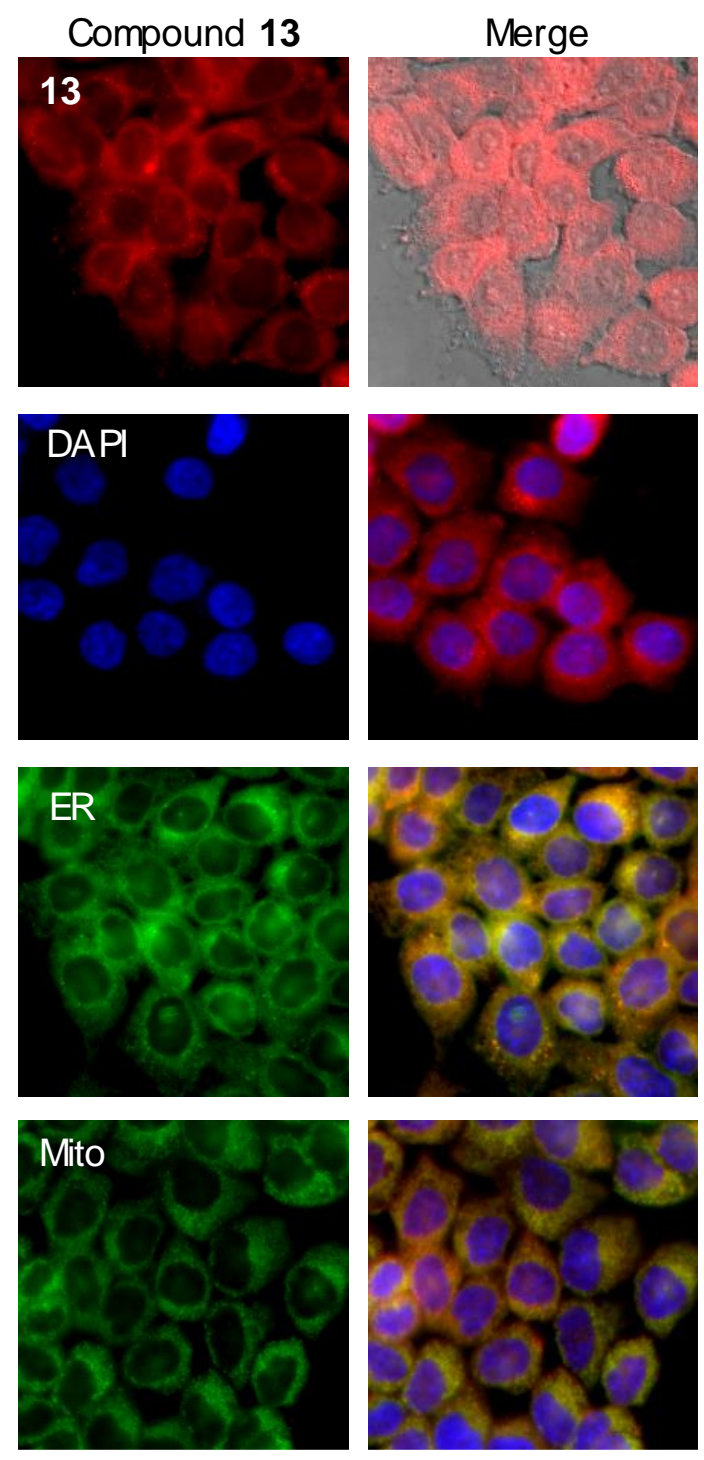

Figure 4.6 Subcellular localization of compounds 13 in Capan-1 cells. Fluorescence images containing synthesized fluorophores are labeled as 13 (red). Images of subcellular organelles stained with commercial fluorescent trackers are labeled as DAPI (blue), ER (green) or Mito (green). The merge columns show images of (top) phase contrast of compound $\mathbf{1 3}$, followed successively below by colocalization of DAPI + compound $\mathbf{1 3}$, colocalization of DAPI + ER + compound 13, and colocalization of DAPI + Mito + compound 13. 
The subcellular localization of $\mathbf{2 , 1 2}$ and $\mathbf{1 3}$ was investigated in Capan-1 cells after $1 \mathrm{~h}$ incubation. Organelle-specific fluorescent probes were used to assess the site-specific uptake of each fluorophore. The preferential intracellular localization of compound $\mathbf{2}$ was within vesicular structures that may embody lipid droplets, endosomes, or other membranebased vesicles. In contrast to 2, compounds $\mathbf{1 2}$ and $\mathbf{1 3}$ demonstrated more homogeneous distribution across cells with extensive accumulation in the mitochondria (Mito) as well as limited accumulation in the nucleus and endoplasmic reticulum (ER). As $\mathbf{1 2}$ and $\mathbf{1 3}$ are cationic, they distribute electrophoretically in the mitochondrial matrix in response to the electric potential across the mitochondrial membrane. ${ }^{31}$ 


\section{CHAPTER 5. PROBE IN VIVO BIODISTRIBUTION STUDIES}

The initial biodistribution profile screening of $\mathbf{2}, \mathbf{1 2}$, and $\mathbf{1 3}$ was carried out in healthy CD-1 mice and compared to MB to assess their pancreas specificity. Compounds 2, 12, $13(100 \mathrm{nmol})$ or MB (120 nmol) were injected intravenously $(n=3$ mice per compound). Fluorescence images were collected prior to fluorophore administration enabling each animal to act as its own control and at $0,5,15,30,60 \mathrm{~min}$ for each of 2, 12, 13 and $\mathrm{MB}$, and additionally at $2 \mathrm{~h}$ and $4 \mathrm{~h}$ for compounds 2,12 and 13 . A series of representative intraoperative fluorescence images taken over time, as well as a resected organ SBR comparison of the dyes, are shown in Fig. 5.1-5.3.

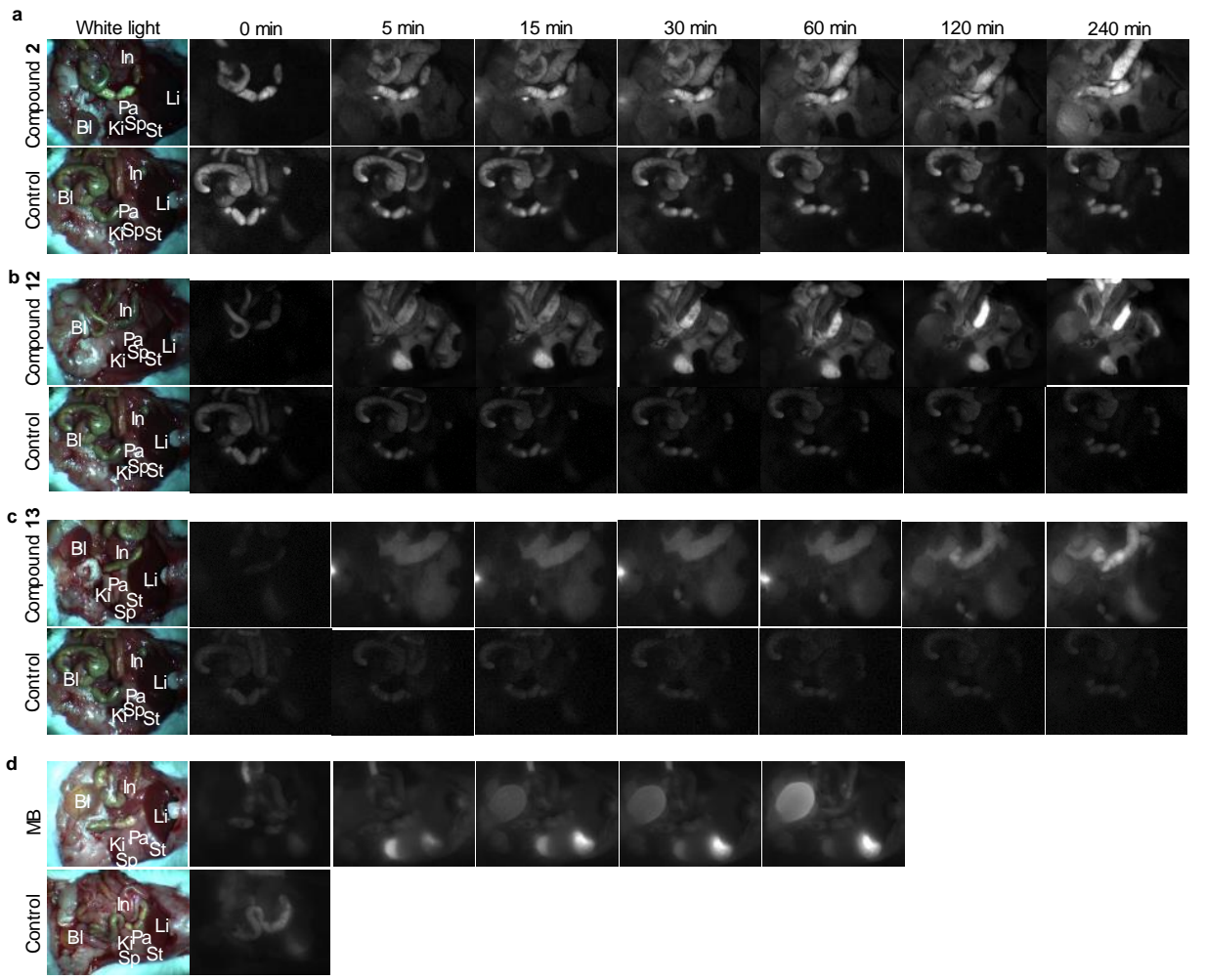

Figure 5.1 Representative real time intraoperative fluorescence imaging of compound 2, 12, 13 and MB. 
Despite their structural similarities, the in vivo biodistribution of each of 2, 12 and 13 was distinct as assessed by intraoperative imaging throughout the $4 \mathrm{~h}$ distribution phase (Fig. 5.1). Compound 2 preferentially accumulated mainly in the pancreas, intestine and bladder, demonstrating significant hepatic clearance. Compound $\mathbf{1 2}$ accumulated in the kidney, pancreas, and intestine, demonstrating both renal and hepatic clearance. Compound 13 accumulated largely in the kidneys, with significant clearance from the other assessed organs $4 \mathrm{~h}$ after systemic administration demonstrating renal clearance.

Although all three probes accumulated in the kidney and liver soon after administration, their preferable clearance routes and rates from these organs differed with respect to renal vs. hepatic clearance. The smallest fluorophore, 2, exhibited the highest bladder fluorescence and faster renal clearance than compounds $\mathbf{1 2}$ and $\mathbf{1 3}$. Compounds $\mathbf{1 2}$ and $\mathbf{1 3}$ cleared more slowly than $\mathbf{2}$ and were retained in the kidney for relatively longer periods. Compound $\mathbf{1 2}$ exhibited a greater hepatic excretion rate as compared to compounds $\mathbf{2}$ and 13. The accumulation profiles of compounds $\mathbf{2}$ and $\mathbf{1 3}$ in the intestine were similar, even though compound $\mathbf{2}$ was more lipophilic and less water soluble compared to compound 13. The overall profiles in other quantified tissues including adipose, spleen, and stomach were similar. 

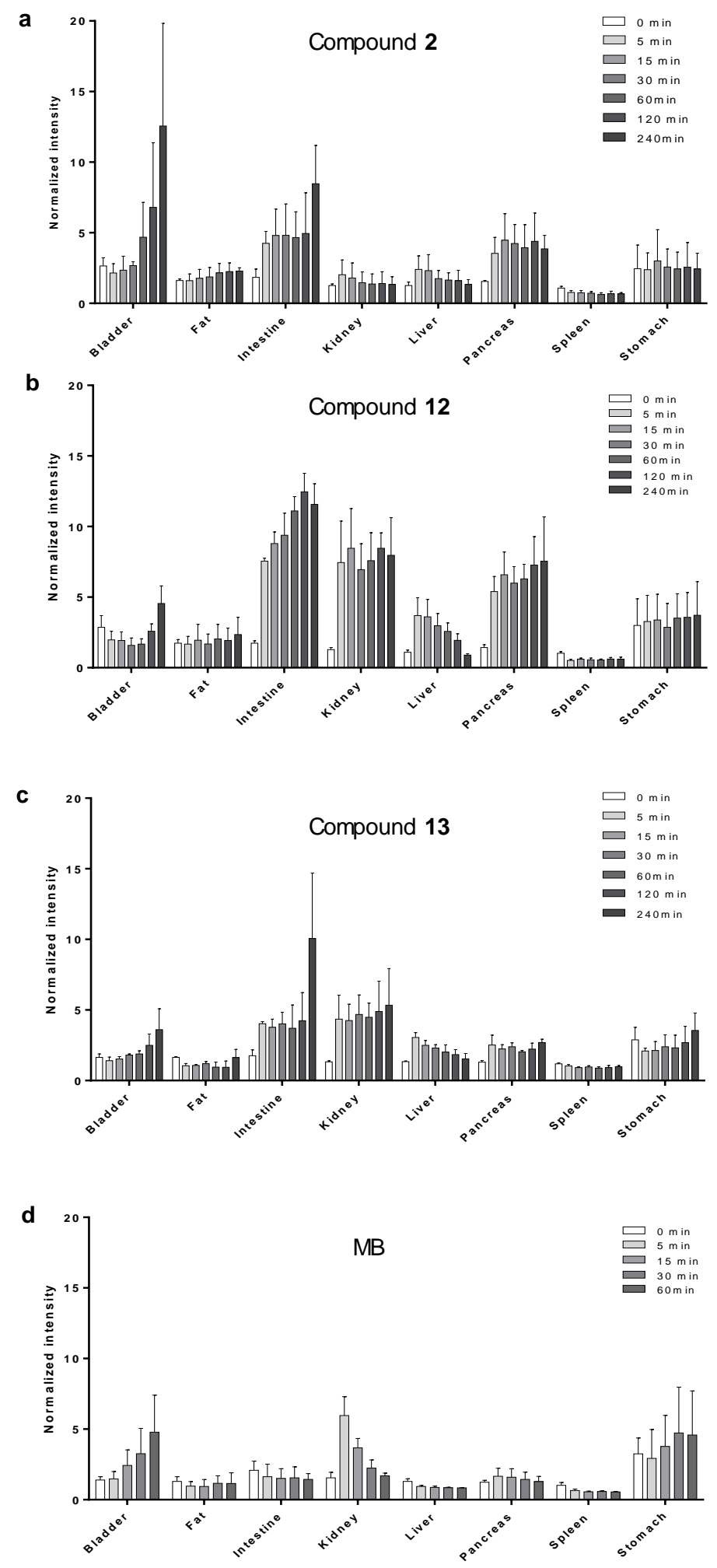

Figure 5.2 In vivo organ biodistribution kinetics of synthesized compounds vs. methylene blue normalized fluorescence intensity. Mean organ fluorescence intensity 
following systemic administration of (a) compound 2, (b) compound 12, (c) compound 13, or (d) MB. Mean fluorescence intensities were calculated for $n=3$ injected mice per compound. Fluorescence intensities for each organ were normalized to muscle fluorescence intensity per animal per time point. Data is presented as the mean \pm S.D.

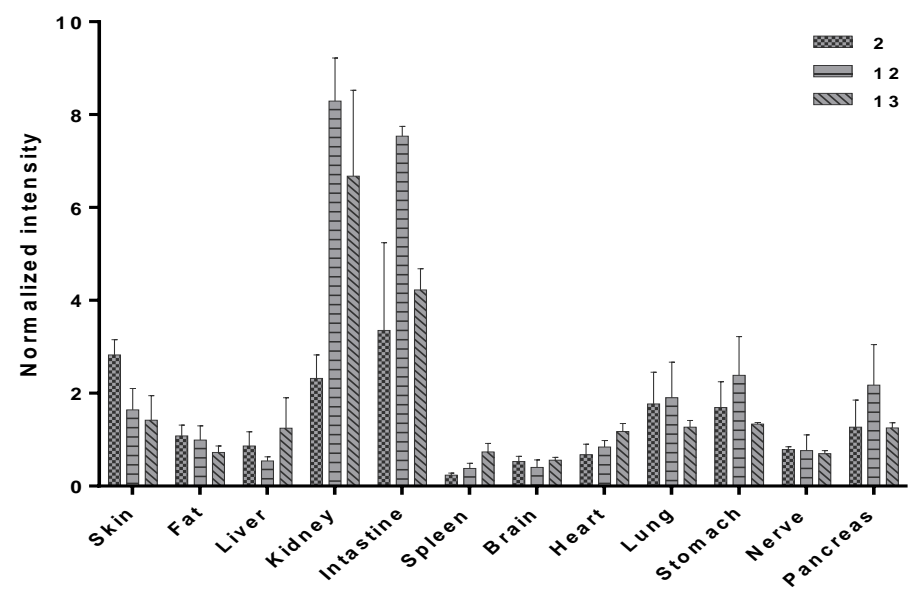

Figure 5.3 Ex vivo resected organ normalized fluorescence intensity comparison of compounds 2, 12 and 13.

Compound 12 exhibited the highest and most persistent fluorescence SBR in the pancreas as compared to surrounding organs at the 4-h time point. It had 4-fold higher uptake in normal pancreas tissue as compared to previously studied MB $(\log \mathrm{D}=-0.62)$. MB extravasated to some degree but demonstrated poor penetration into normal pancreas tissue (Fig. 5.1-5.2). The low in vivo efficacy of MB could be attributed to its relatively low lipophilicity and high water solubility, as it is preferentially and rapidly cleared through the renal system after systemic administration. MB's low tissue fluorescence, rapid clearance rate and reduced bioavailability limited its pancreas tissue selectivity and thus its potential for image-guided surgery applications. From the study herein, higher $\log \mathrm{D}$ value compounds 2 and 12 exhibited improved pancreas specificity whereas $\mathbf{1 3}$ and MB had relatively lower $\log \mathrm{D}$ values and diminished pancreas accumulation. Examination of the 
biodistribution and tissue permeability ${ }^{28,32}$ of more members of the benzo[c]xanthene and related dye series will further validate these and related trends, and is ongoing. 


\section{CHAPTER 6. GENETICALLY ENGINEERED MOUSE MODELS OF PDAC IMAGING}

Genetically engineered mouse models of PDAC tumors that recapitulate the clinical, pathological and genomic features of human PDAC $^{33-35}$ were used to assess the specificity of the fluorophores for PDAC accumulation. Compound $\mathbf{1 2}$ afforded the highest pancreas tissue uptake in healthy mice and was chosen for study in the genetically modified PDAC tumor-bearing mouse model.

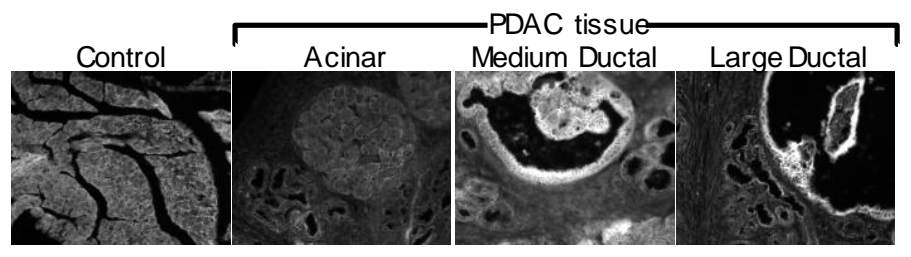

Figure 6.1 Ex vivo microscopy images of control and PDAC tissue slides stained with compound 12. Microscopy images of compound 12 stained pancreas tissue slides showing representative large, medium duct type adenocarcinoma tissue and acinar cells resected from PDAC tumor bearing mice compared with the one resected from a healthy mouse pancreas (left).

Ex vivo staining of pancreas tissue derived from healthy and PDAC mice showed that their characteristic features were highlighted by 12 (Fig. 6.1). The healthy mouse pancreas tissue showed uptake of $\mathbf{1 2}$ in its abundant acinar cell population. In contrast, in the cancerous tissue, 12 localized in the PDAC-associated ductal epithelial cells, enabling them to be observed via an increased fluorescence signal that was visually brighter 
compared to that of the acinar cells in healthy tissue. Thus, $\mathbf{1 2}$ enabled ex vivo staining to distinguish the features of healthy and PDAC tissue.
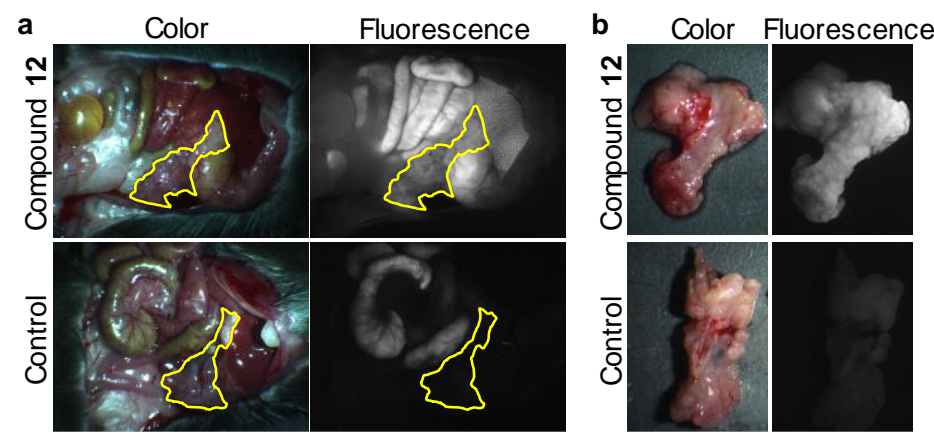

Figure 6.2 Real time intraoperative fluorescence imaging of PDAC tumor bearing mice injected with compound 12. a, the location of the pancreas in the peritoneal cavity is shown outlined in yellow, with (top) and without (bottom) compound $\mathbf{1 2}$ administration. In the images, the pancreas is observed only after injection of $\mathbf{1 2}$. b. Macroscopic images of resected pancreas tissue from PDAC tumor bearing mice ex vivo either following systemic administration of compound $\mathbf{1 2}$ (top) or from an uninjected PDAC tumor bearing mouse (bottom) confirming the lack of pancreas fluorescence without 12. The images of mice injected with $\mathbf{1 2}$ are representative of data collected for $n=5$ injected PDAC mice. All fluorescence images were collected at $50 \mathrm{~ms}$ exposure time. Images are displayed with equal normalization between compound $\mathbf{1 2}$ and the uninjected control. Imaging results demonstrates morphology and tissue uptake differences between the healthy mice and PDAC tumor bearing mice, as well as the fluorescence resulting from $\mathbf{1 2}$ versus autofluorescence.

Compound $\mathbf{1 2}$ was systemically administered to $n=5$ genetically modified PDAC mice. Pancreas specific fluorescence was monitored over $1.5 \mathrm{~h}$. Significantly more fluorescence was seen in compound $\mathbf{1 2}$ injected PDAC bearing animals compared to uninjected control PDAC bearing animals. After euthanasia, the pancreas was assessed microscopically for PDAC specific fluorophore accumulation. Representative 
intraoperative fluorescence images over time as well as the in vivo organ biodistribution kinetics of compound $\mathbf{1 2}$ are shown in Fig. 6.3.

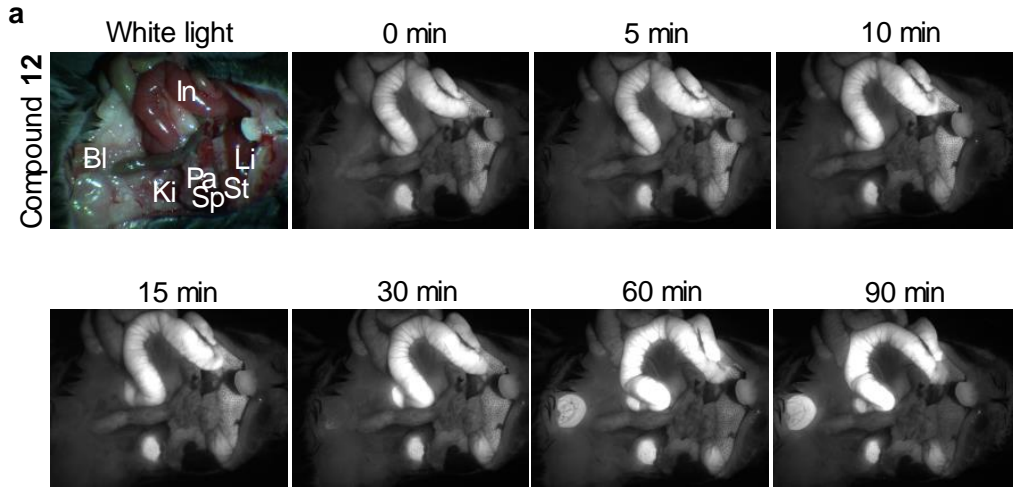

b

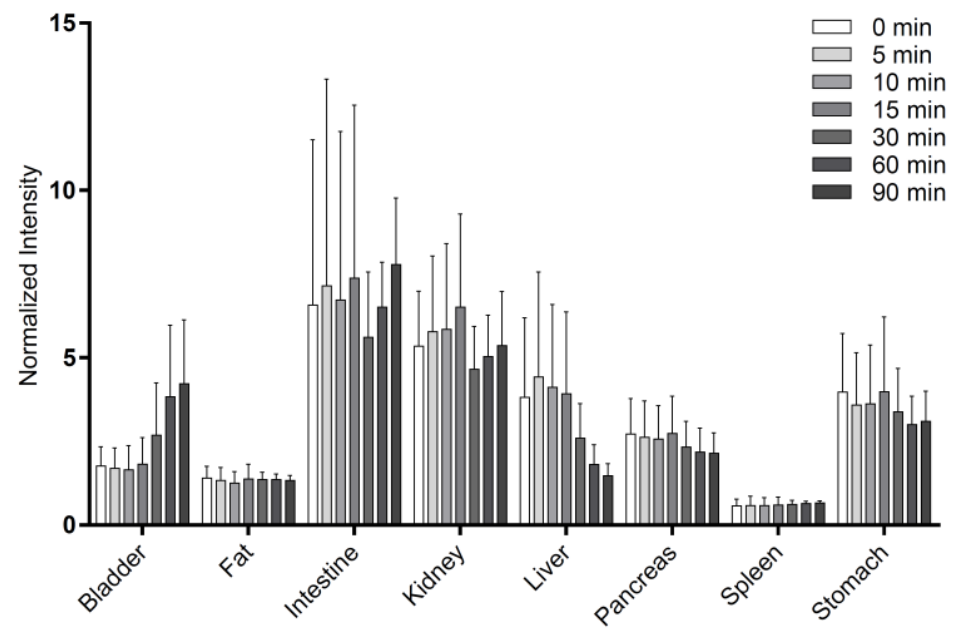

Figure 6.3 Biodistribution of compound 12 in PDAC mice. a, Representative images of the fluorescence intensity in the peritoneal cavity over time following systemic administration of compound $\mathbf{1 2}$ in PDAC tumor bearing mice; $\mathbf{b}$, corresponding mean fluorescence intensities measured for each organ. All images are representative of data collected for $n=5$ systemically administered mice. All fluorescence images were collected at $50 \mathrm{~ms}$ exposure time. All images are displayed with equivalent normalization between time points. Quantified fluorescence intensity for each organ was normalized to the muscle intensity per animal per time point. Data is presented as the mean \pm S.D. In $=$ Intestine; $\mathrm{Li}$ $=$ liver $; \mathrm{Pa}=$ pancreas $; \mathrm{Sp}=$ spleen $; \mathrm{St}=$ stomach $; \mathrm{Bl}=$ Bladder $; \mathrm{Ki}=$ Kidney . 

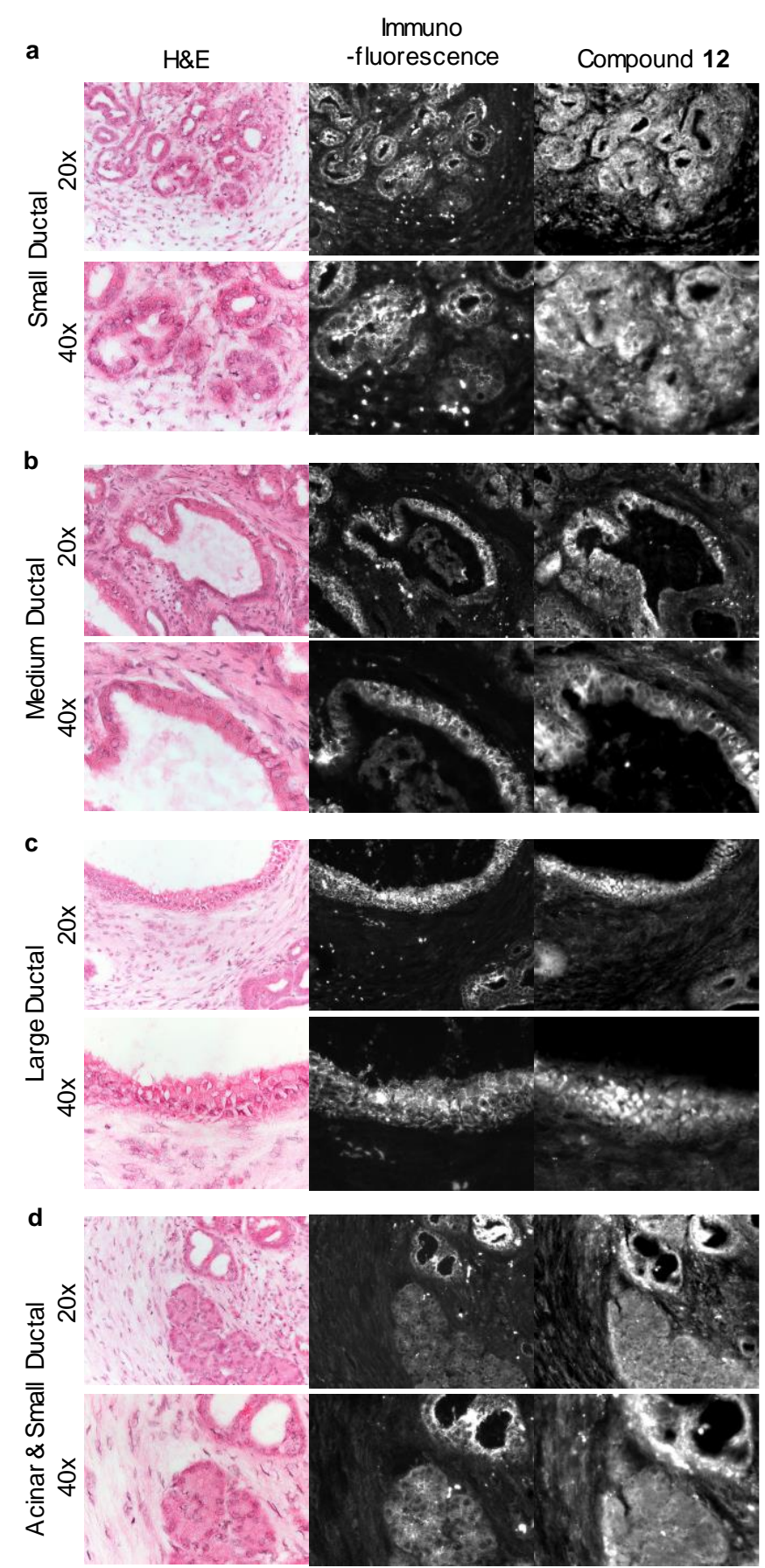

Figure 6.4 Ex vivo pathology of resected PDAC tissue. Microscopy images of H\&E, pan-cytokeratin and compound 12 stained slides showing representative (a) small, (b) medium, and (c) large duct type adenocarcinoma tissue as well as (d) acinar cells resected from PDAC tumor bearing mice injected with 12. Pan-cytokeratin antibody staining 
highlights PDAC cells. Comparison to the fluorescence images obtained with $\mathbf{1 2}$ to those obtained with the antibody confirms their similar PDAC staining patterns.

a

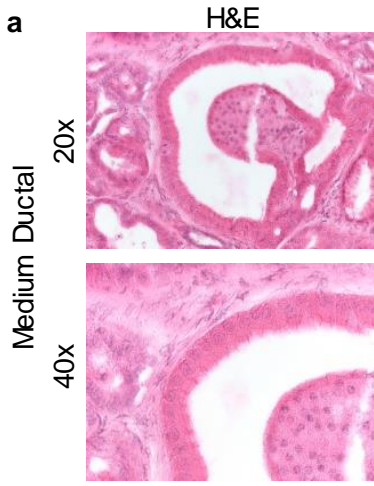

b
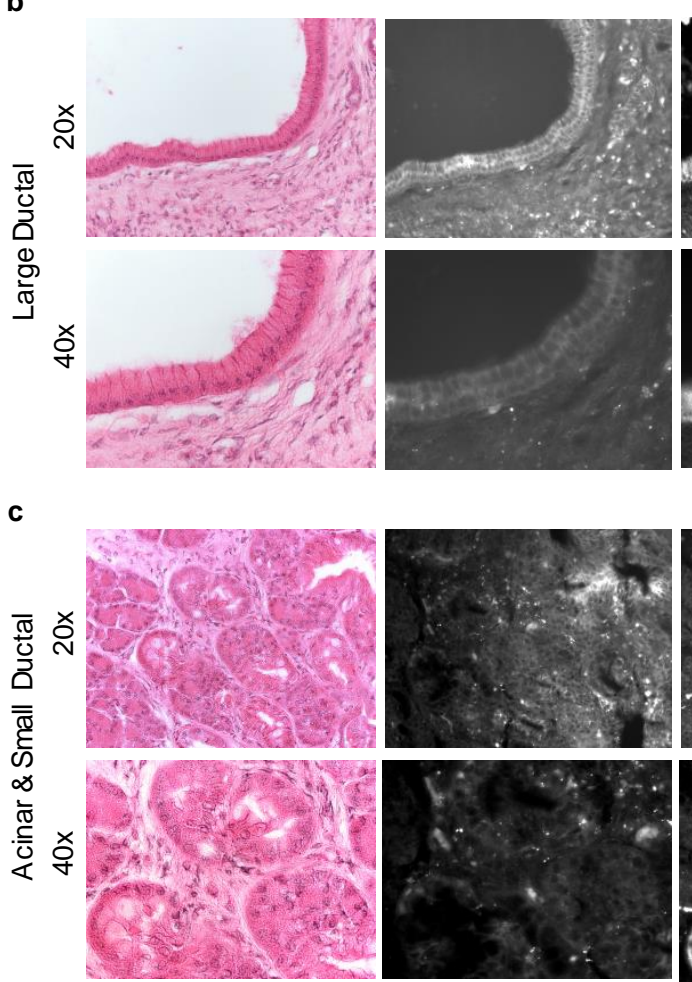

IF - Control
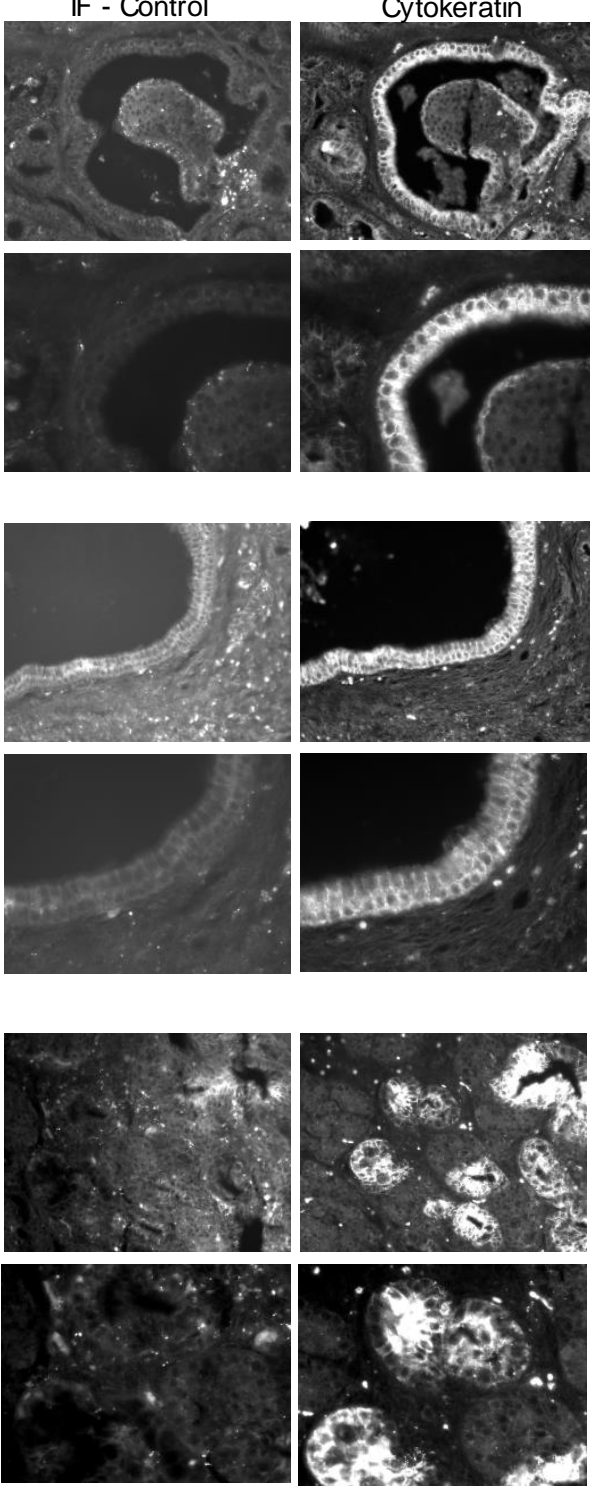

Autofluorescence
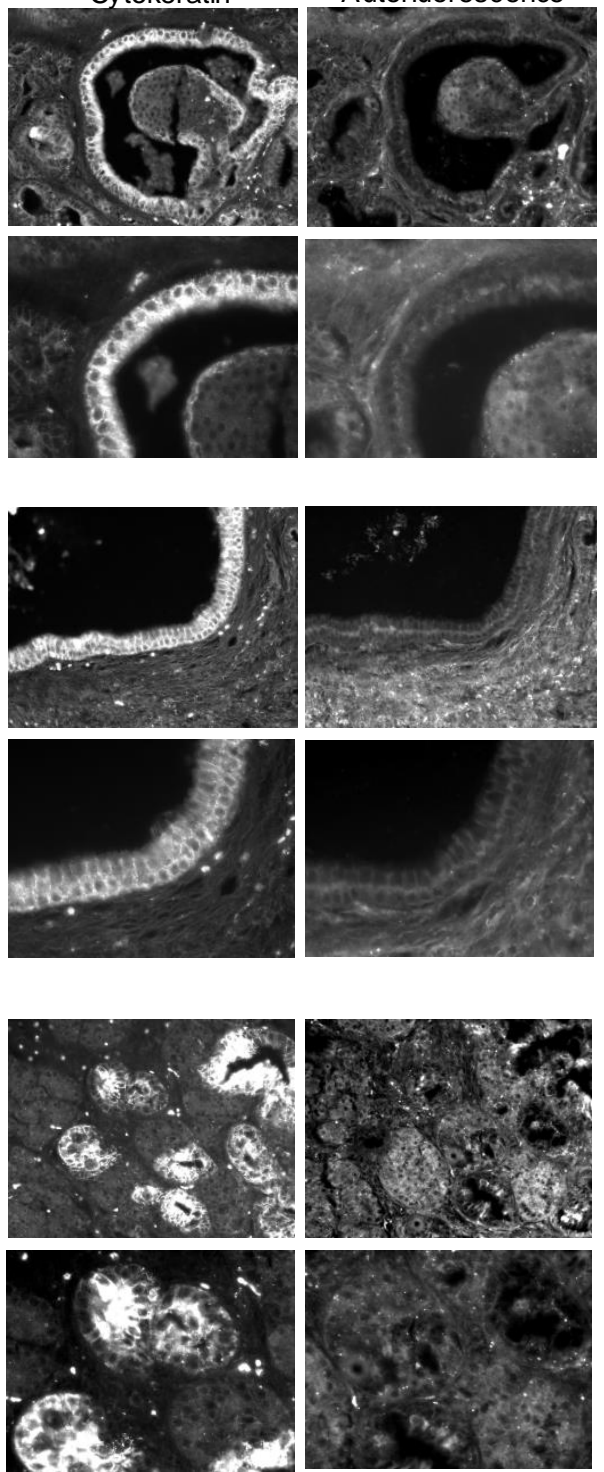

Figure 6.5 Ex vivo pathology of resected PDAC tissue from uninjected control mice.

Representative microscopy images of (a) medium and (b) large duct type adenocarcinoma tissue and of (c) normal pancreatic acinar cells next to small duct type adenocarcinoma tissue resected from uninjected PDAC tumor bearing mice. Control IF images were collected from serial sections that had been stained using the same procedure as those for cytokeratin visualization, but with blank staining solution to demonstrate antibody staining 
specificity. Images were collected in the compound 12 fluorescence channel and were normalized to compound 12 fluorescence images in Fig. 6.4 for each respective tissue type to demonstrate autofluorescence in the compound $\mathbf{1 2}$ fluorescence channel in unstained PDAC tissue.

Representative serially sectioned tissues stained with pan-cytokeratin to assess PDAC specificity of compound $\mathbf{1 2}$ confirmed that accumulation of compound $\mathbf{1 2}$ in PDAC tumor tissue was significantly higher than in the surrounding tissues and specific for the malignant cells (Fig. 6.4). Hematoxylin and Eosin (H\&E) staining of the PDAC specimens revealed that uptake of $\mathbf{1 2}$ occurred in ductal tissue epithelial cells. This is consistent with the fact that pancreatic ductal epithelial cells give rise to PDAC. ${ }^{36}$ Furthermore, the accumulation of $\mathbf{1 2}$ in PDAC mouse acinar cells (Fig. 6.4d) also demonstrated colocalization with the pan-cytokeratin immunofluorescence staining. This is apparently in keeping with studies that have shown that genetic mutations of acinar cells are associated with precancerous pancreatic intraepithelial neoplasia that progresses to PDAC over time. 37-41 


\section{CHAPTER 7. SUMMARY AND OUTLOOK}

Early detection and improved treatment options have increased the survival rate of many prevalent cancers such as those of the breast, colon, and prostate. However, to date surgical resection offers the only chance for a cure for PDAC due to relatively late detection. Cancer cure is directly related to the margin status of the resected tumor; ${ }^{42,43}$ however, complete resection with negative margins remains a major challenge. ${ }^{6,44}$ This leaves many patients with residual disease, leading to early cancer recurrence following what was thought to be a potentially curative operation. ${ }^{45}$ The utilization of engineered antibodies has been assessed for identifying margin status, as they can enable targeting of imaging probes to cancer cells in vivo. ${ }^{46,47}$ However, antibody imaging probes have relatively long retention times in non-targeted tissues and slow clearance from circulation as compared to small molecule fluorophores. Furthermore, due to poor cell-membrane permeability, antibody-based imaging is limited in its applications to cell-surface biomarkers. ${ }^{48}$

During the past few years, a limited number of small molecule fluorescent probes for PDAC have been reported that are conjugated to targeting moieties smaller than antibodies. ${ }^{49-54}$ Like their antibody counterparts, they were designed to target specific proteins (e.g., cathepsins, matrix metalloproteinases, claudin- 4 or integrin integrin $\alpha_{v} \beta_{3}$ ) that are overexpressed in PDAC as well as other cancers. All probes of this type require conjugation to a peptide or peptidomimetic, where the biodistribution of the conjugated probe will be dependent upon both the targeting sequence and the conjugated fluorophore. Moreover, selective intracellular accumulation of the protein-targeted probes to enable the 
discrimination of individual healthy and PDAC cells is rare. ${ }^{52}$ In contrast, probe $\mathbf{1 2}$ possesses inherent pancreas and PDAC mitochondria specificity without the need for modification or target conjugation.

In addition to image guided surgery, a major motivation for designing PDAC probes is to facilitate early detection. The 5-year survival rate of patients with PDAC is < $8 \%{ }^{1}$ Because most cases are diagnosed in the late stages, $<20 \%$ of all patients have resectable tumors. ${ }^{4}$ Early detection is of paramount importance as early-stage PDAC surgery can result in 4-year survival rates of up to 78\%, a vast improvement over today's survival rate. ${ }^{55}$ This has prompted the investigation of fluorescent probes for the ability to target PDAC as well as pancreatic intraepithelial neoplasia (PanIN), the lesions that occur in the pancreatic ducts that are preinvasive precursors of PDAC. ${ }^{56}$ In addition to pancreatic ductal epithelial cells, there is growing evidence that the transdifferentiation of alternative pancreatic cell types, such as acinar cells, embodies an alternative pathway to PDAC. ${ }^{37-41}$ Compound 12 stains acinar cells as well as PDAC-associated ductal epithelial cells (Fig. 6.4), thus it has potential utility in investigating PDAC progression and early detection.

At the intracellular level, compound $\mathbf{1 2}$ (as well as 13) targets mitochondria in PDAC cells (Fig. 4.5 and 4.6). Mitochondrial dysfunction is central to the pathogenesis of PDAC. ${ }^{43,44}$ For example, cells surviving oncogene ablation have been found to be responsible for PDAC tumor relapse, and are strongly reliant on mitochondrial respiration rather than on glycoloysis. ${ }^{57}$ There are, moreover, several ongoing investigations of therapeutic strategies for PDAC involving modulation of mitochondrial function. ${ }^{57-60}$

In conclusion, the synthesis of a focused probe library with predictable physicochemical properties afforded a simple molecular probe (12) enabling the imaging 
of PDAC in a genetically engineered mouse model. Conjugation to a biological targeting agent was not required for PDAC tumor specificity. The fluorescent probe functioned at the level of the whole organ, enabling visualization of a cancerous pancreas with excellent SBR. It targeted PDAC tissue and cells as evidenced by comparison with H\&E staining and immunohistochemistry, and allowed for ready distinction between individual cell morphologies. At the subcellular level, it demonstrated accumulation in the mitochondria. Compound 12 is thus a unique tool, enabling the imaging of PDAC at four different levels of structure in a genetically engineered mouse model. It thus possesses desirable properties for promoting more refined pancreatic cancer detection, therapeutic monitoring and imageguided surgery. 


\section{CHAPTER 8. METHODS}

\subsection{Physicochemical Property Prediction and Molecular Modeling.}

Physicochemical partition coefficients (Log D) values at $\mathrm{pH} 7.4$, were calculated using Marvin and JChem calculator plugins (ChemAxon, Budapest, Hungary). Molecular orbital, UV-Vis spectra and electrostatic maps calculations were performed using Density Functional Theory (DFT) modeling on gas-phase B3LYP/6-31G optimized geometries using Gaussian 09. ${ }^{61}$

\subsection{Synthesis of Fluorescent Probes.}

Seminaphthofluorescein, seminaphthorhodafluors and seminaphthorhodamines (Fig. 1.1) were synthesized in two to three steps. The initial step involved the condensation of hydroxybenzophenones with the corresponding naphthols in a mixture of $\mathrm{CH}_{3} \mathrm{SO}_{3} \mathrm{H}$ :TFA $1: 1$ at $80^{\circ} \mathrm{C}$ for $16-24 \mathrm{~h}$ to produce the lactones or carboxylates. Subsequent Fisher esterification to produce the methyl esters derivatives was carried out in $\mathrm{MeOH}$ catalyzed by either $\mathrm{H}_{2} \mathrm{SO}_{4}$ or $\mathrm{HCl}$. Further alkylation was attained by treatment of either the carboxylate or methyl ester intermediate with methyl iodide in the presence of $\mathrm{K}_{2} \mathrm{CO}_{3}$ in $\mathrm{DMF}$ to produce the corresponding methyl ethers. The required starting materials; 2-(2,4-dihydroxybenzoyl)benzoic acid, 2-(4-amino-2-hydroxybenzoyl)benzoic acid, 2-(8-hydroxy-1,2,3,5,6,7-hexahydropyrido[3,2,1-ij]quinoline-9-carbonyl)benzoic acid and 1,8-naphthalene derivatives were synthesized according to described or modified literature protocols. In general, overall good yields were obtained for most of the fluorophores included in this series with the exception of the condensation products 
between 2-(2,4-dihydroxybenzoyl)benzoic acid and 8-amino naphthol derivatives $\mathbf{7}$ and $\mathbf{8}$, where the major isolated product corresponded to fluorescein. All compounds were isolated by flash column chromatography or preparative TLC, and characterized by NMR and HR ESI MS.

\subsection{UV-Vis Absorption and Fluorescence Spectroscopy.}

UV-Vis spectra were collected with a Cary $50 \mathrm{UV}$-Vis spectrophotometer at rt using a reduced volume $1-\mathrm{cm}$ quartz cuvette. Fluorescence spectra were collected on a Cary Eclipse fluorescence spectrophotometer (Agilent Technologies). All absorption spectra were reference corrected. Fluorescence spectra were corrected for the wavelength dependent response of the R928 photomultiplier tube using a manufacturer generated correction file. Quantum yields were reported as the average of multiple measurements using multiple references. Excitation emission matrices (EEMs) were collected over various spectral regions, using 5- or 10-nm step sizes for emission and excitation. The band pass for excitation and emission was 5 to $10 \mathrm{~nm}$.

\subsection{Cell Culture.}

The human PDAC cell line Capan-1 was obtained from Dr. Rosalie Sears's laboratory at Oregon Health and Science University (OHSU) and maintained in RPMI medium (Gibco) in a humid atmosphere at $37^{\circ} \mathrm{C}$ with $5 \% \mathrm{CO}_{2}$. All media were supplemented with $10 \% \quad(\mathrm{v} / \mathrm{v})$ fetal bovine serum (FBS), and $1 \% \quad(\mathrm{v} / \mathrm{v})$ penicillin/streptomycin. Cell viability was determined by Cell Titer-Blue assay. Monolayers of $10^{4}$ Capan- 1 cells were seeded in triplicate in 96 well plates and incubated with decreasing concentration from $100 \mu \mathrm{M}$ of each compounds in growth media 
containing $10 \%$ FBS. After $24 \mathrm{~h}$ incubation time, $20 \mu \mathrm{L}$ of Cell Titer-Blue reagent was added into each well and culture cells were incubated for additional $2 \mathrm{~h}$. Fluorescence intensity in each well was recorded at 560/590 nm using a SpectraMax M5 Microplate Reader. The half maximal inhibitory concentrations ( $\left.\mathrm{IC}_{50}\right)$ of $\mathbf{2 , 1 2}$ and $\mathbf{1 3}$ were determined from interpolating values in the graph (\% cell viability vs. fluorophore concentration). For the comparison of cellular uptake rates in Capan-1 cells, the absorbance of the media was measured as background, and the absorbance of the supernatant was obtained to determine the cellular uptake by using the absorbance of $10 \mu \mathrm{M}$ fluorophore in cell free media as standard reference.

\subsection{In Vitro Live Cell Imaging.}

Monolayers of $10^{4}$ Capan-1 cells were seeded in triplicate in 8 well plates and incubated for $24 \mathrm{~h}$ in growth media containing 10\% FBS, and allowed to attach. For subcellular colocalization experiments, media was extracted and cells were washed with PBS, and phenol red-free growth medium was added to each well. Organelle trackers were added to each well, and incubated with the fluorophore of interest (final concentration 0.5 $\mu \mathrm{M})$ for $1 \mathrm{~h}$. Cells were washed with PBS and fixed with 2\% paraformaldehyde (PFA). Fluorescence microscopy was carried out using a Zeiss inverted microscope with an Axioscan fluorescence camera for imaging. The final concentrations of organelle trackers used were: DAPI $0.5 \mu \mathrm{M}$, Mito-tracker green $0.5 \mu \mathrm{M}$, and ER-tracker green $1 \mu \mathrm{M}$.

\subsection{Animals.}

Approval for the use of all animals in this study was obtained from the Institutional Animal Care and Use Committee (IACUC) at OHSU. Male CD-1 mice weighing 22-24 g 
were purchased from Charles River Laboratories (Wilmington, MA). Genetically engineering mouse models of PDAC based on the targeted expression of an oncogenic KRAS mutation (KRAS ${ }^{\mathrm{G} 12 \mathrm{D}}$ ) in the mouse pancreas were used to model the human disease. Mice expressing the KRAS mutation alone, termed "KC mice", develop the full range of intraductal neoplastic lesions (PanINs) that are histologically indistinguishable from human PanINs. The mice develop PanINs with $100 \%$ penetrance, but these lesions do not progress to metastatic disease. ${ }^{62,63} \mathrm{~A}$ modification of the $\mathrm{KC}$ mouse that was developed in the laboratory of Dr. Rosalie Sears (Department of Molecular \& Medical Genetics, Oregon Health and Science University) was used to more closely model human PDAC. This mouse model, termed "KMC mice", included overexpression of the wildtype Myc oncogene, ${ }^{64,65}$ similar to their previously published breast cancer mouse models. ${ }^{66}$ This pancreatic cancer mouse model developed PanIN lesions by 10 weeks of age and rapidly progressed to PDAC including metastatic disease, more closely representing the human disease (Sears Lab OHSU, unpublished data). Both $\mathrm{KC}$ and $\mathrm{KMC}$ mice were used to assess compound 12 accumulation in PDAC. All animals were placed on 5V75 chlorophyll free diet from TestDiet (St. Louis, MO) 1 week prior to any imaging studies. Prior to surgery, mice were anaesthetized with $100 \mathrm{mg} / \mathrm{kg}$ ketamine and $10 \mathrm{mg} / \mathrm{kg}$ xylazine (Patterson Veterinary, Devens, MA). The peritoneal cavity was surgically exposed by removal of overlaying skin and muscle tissue to image fluorophore biodistribution following intravenous injection.

\subsection{Intraoperative Fluorescence Imaging System.}

In vivo murine biodistribution images and macroscopic images of resected tissues were acquired using a custom-built small animal imaging system capable of real time color and fluorescence imaging. The imaging system consists of a QImaging EXi Blue 
monochrome camera (Surrey, British Columbia, CA) for fluorescence detection with a removable Bayer filter for collecting co-registered color and fluorescence images. A PhotoFluor II light source (89 North, Burlington, VT) was focused onto the surgical field through a liquid light guide and used unfiltered for white light illumination. For fluorescence detection, the light source was filtered with a $545 \pm 12.5 \mathrm{~nm}, 620 \pm 30 \mathrm{~nm}$, or a $650 \pm 22.5 \mathrm{~nm}$ bandpass excitation filter for compound 2 and $\mathbf{1 2}$, compound $\mathbf{1 3}$, and $\mathrm{MB}$ fluorescence excitation, respectively. Resulting fluorescence was collected with a $605 \pm 35$ $\mathrm{nm}, 700 \pm 37.5 \mathrm{~nm}$, or $720 \pm 30 \mathrm{~nm}$ bandpass emission filter for compound $\mathbf{2}$ and $\mathbf{1 2}$, compound 13, and MB image collection, respectively. All filters were obtained from Chroma technology (Bellows Falls, VT). Camera exposure times ranged from 50 to 200 ms for fluorescence image collection. All images collected for comparison between treatment groups were acquired with the same exposure time and are displayed under equal normalized brightness and contrast levels where indicated.

\subsection{Systemic Administration of Fluorescent Compounds.}

For initial in vivo testing and biodistribution studies $100 \mathrm{nmol}$ of compounds $\mathbf{2 , 1 2}$, and 13 were injected systemically. Fluorophores were diluted in PBS. For comparison with

previous studies, ${ }^{7} 120 \mathrm{nmol} \mathrm{MB}$ was injected systemically. Mice were administered blank PBS for control images ( $n=3$ mice per group, 5 groups). For PDAC tumor mice model testing $100 \mathrm{nmol}$ of compound $\mathbf{1 2}$ was injected systemically ( $n=5$ mice).

\subsection{In Vivo Biodistribution Imaging.}

The biodistribution of compounds 2, 12, and 13 was assessed using the intraoperative fluorescence imaging system to collect images of the peritoneal cavity. The 
peritoneal cavity was exposed and images were collected so that the bladder, adipose tissue, intestine, kidney, liver, muscle, pancreas, spleen, and stomach were visible within the field of view. For initial biodistribution studies images were collected immediately after injection and at 5, 15, 30, 60, 120, and 240 min following injection. For MB injected mice, images were collected on the same time course, but only out to $60 \mathrm{~min}$ due to the rapid clearance of methylene blue. ${ }^{7}$ For PDAC tumor bearing mice, images were collected immediately after injection and at 5, 15, 30, 60, and 90 min following injection. Vehicle injected control animals were imaged on the same time course as fluorophore injected animals for initial testing or immediately following injection only for studies involving MB or PDAC tumor bearing mice to assess tissue autofluorescence for comparison to injected animals.

Fluorophore biodistribution kinetics were measured using region of interest analysis on images collected of the peritoneal cavity. Mean fluorescence intensities in each organ or tissue type were measured from images collected at each time point. All intensities were normalized to the muscle intensity at that time point by dividing by the measured muscle intensity. Using the normalized fluorescence intensities for each organ or tissue type, mean intensities were calculated for each group.

Upon completion of initial biodistribution studies, animals were euthanized and their organs were resected. Macroscopic images of the resected organs were collected using the intraoperative fluorescence imaging system and the mean fluorescence intensity of each resected organ was measured using region of interest analysis. Fluorescence intensities were normalized to the muscle intensity in the same manner as in vivo measurements. Mean intensities were calculated for each group using the normalized values. For biodistribution 
studies in PDAC tumor bearing mice, only the pancreas was resected and imaged following euthanasia.

\subsection{Ex Vivo Fluorescence Microscopy, Pathology, and Immunofluorescence}

\section{Staining.}

Resected pancreas tissue from compound $\mathbf{1 2}$ in vivo biodistribution studies with PDAC tumor bearing mice was fixed with $2 \%$ PFA for $12 \mathrm{~h}$, flash frozen in optimal cutting temperature (OCT) compound with liquid nitrogen, and stored at $-80{ }^{\circ} \mathrm{C}$. Cryosections were cut at $10 \mu \mathrm{m}$ onto Superfrost Plus slides (Fisherbrand, Fisher Scientific). Slides were mounted with Fluoromount-G (Southern Biotech, Birmingham, AL) and coverslipped. Serial sections were obtained for cytokeratin immunofluorescence microscopy enabling imaging of compound 12 and immunofluorescence labeling with $0.01 \mathrm{mg} / \mathrm{mL}$ of directly labeled anti-pan cytokeratin conjugated to AlexaFluor 488 (eBioscience, San Diego, CA). Briefly, slides were rinsed with PBS for 2 min to remove residual OCT. Then, slides were fixed by immersion in 2\% PFA for 15 min and washed with PBS for 5 min three times. Primary antibody was incubated on the slides for $1 \mathrm{~h}$ at room temperature. Following incubation, slides were washed with PBS three times for 5 min each and then post-fixed with PFA for $15 \mathrm{~min}$ and washed with PBS once for 5 min before mounting with Fluoromount-G. For cytokeratin immunofluorescence controls, serial sections were stained using the above immunofluorescence procedure but without antibody present in the staining solution that was incubated on the slides. For H\&E pathological analysis, slides previously stained for cytokeratin expression were unmounted and rinsed with PBS to remove residual mounting media prior to $H \& E$ staining. Images were acquired on an Axio

Observer inverted fluorescence microscope (Zeiss, Thornwood, NY) at 10, 20, or 40x 
magnification. A PhotoFluor II was used unfiltered for H\&E color images and filtered using a $545 \pm 12.5 \mathrm{~nm}$ or $470 \pm 20 \mathrm{~nm}$ bandpass excitation filter for compound $\mathbf{1 2}$ or Atto 488 excitation, respectively. Color images were collected using an Axiocam 105 camera (Zeiss) and fluorescence images were collected using an Axiocam 506 camera (Zeiss) where a $605 \pm 35 \mathrm{~nm}$ or $525 \pm 25 \mathrm{~nm}$ bandpass emission filter was used for compound $\mathbf{1 2}$ or Atto 488 fluorescence image collection, respectively. 


\section{REFERENCES}

1. Siegel, R. L., Miller, K. D. \& Jemal, A. Cancer statistics, 2016. CA Cancer J. Clin. 66, 7-30, (2016).

2. Rahib, L. et al. Projecting cancer incidence and deaths to 2030: The unexpected burden of thyroid, liver, and pancreas cancers in the united states. Cancer Res. $\mathbf{7 4}$, 2913-2921, (2014).

3. Stathis, A. \& Moore, M. J. Advanced pancreatic carcinoma: current treatment and future challenges. Nat. Rev. Clin. Oncol. 7, 163-172, (2010).

4. $\quad$ Li, D., Xie, K., Wolff, R. \& Abbruzzese, J. L. Pancreatic cancer. The Lancet 363, 1049-1057, (2004).

5. Michalski, C. W., Weitz, J. \& Buchler, M. W. Surgery Insight: surgical management of pancreatic cancer. Nat. Clin. Prac. Oncol. 4, 526-535, (2007).

6. Verbeke, C. S. Resection margins and R1 rates in pancreatic cancer--are we there yet? Histopathology 52, 787-796, (2008).

7. Winer, J. et al. Intraoperative localization of insulinoma and normal pancreas using invisible near-infrared fluorescent light. Ann. Surg. Oncol. 17, 1094-1100, (2010).

8. van der Vorst, J. R. et al. Near-infrared fluorescence imaging of a solitary fibrous tumor of the pancreas using methylene blue. World J. Gastrointest. Surg. 4, 180184, (2012).

9. Hutteman, M. et al. Near-infrared fluorescence imaging in patients undergoing pancreaticoduodenectomy. Eur. Surg. Res. 47, 90-97, (2011).

10. Keereweer, S. et al. Optical image-guided surgery--where do we stand? Mol. Imaging Biol. 13, 199-207, (2011).

11. Frangioni, J. V. New technologies for human cancer imaging. J. Clin. Oncol. 26, 4012-4021, (2008).

12. van Dam, G. M. et al. Intraoperative tumor-specific fluorescence imaging in ovarian cancer by folate receptor-alpha targeting: first in-human results. Nat. Med. 17, 1315-1319, (2011). 
13. Gioux, S., Choi, H. S. \& Frangioni, J. V. Image-guided surgery using invisible nearinfrared light: fundamentals of clinical translation. Mol. imaging 9, 237-255 (2010).

14. Ntziachristos, V., Yoo, J. S. \& van Dam, G. M. Current concepts and future perspectives on surgical optical imaging in cancer. J. Biomed. Opt. 15, 066024, (2010).

15. Gibbs, S. L. Near infrared fluorescence for image-guided surgery. Quant. Imaging Med. Surg. 2, 177-187, (2012).

16. Vahrmeijer, A. L., Hutteman, M., van der Vorst, J. R., van de Velde, C. J. \& Frangioni, J. V. Image-guided cancer surgery using near-infrared fluorescence. Nat. Rev. Clin. Oncol. 10, 507-518, (2013).

17. Keereweer, S. et al. Optical image-guided cancer surgery: challenges and limitations. Clin. Cancer Res. 19, 3745-3754, (2013).

18. Provenzano, P. P. et al. Enzymatic targeting of the stroma ablates physical barriers to treatment of pancreatic ductal adenocarcinoma. Cancer Cell 21, 418-429, (2012).

19. Choi, H. S. et al. Targeted zwitterionic near-infrared fluorophores for improved optical imaging. Nat. Biotechnol. 31, 148-153, (2013).

20. Chang, R. L. et al. Permselectivity of the glomerular capillary wall to macromolecules. II. Experimental studies in rats using neutral dextran. Biophys. J. 15, 887-906, (1975).

21. Rennke, H. G., Patel, Y. \& Venkatachalam, M. A. Glomerular filtration of proteins: Clearance of anionic, neutral, and cationic horseradish peroxidase in the rat. Kidney Int. 13, 278-288, (1978).

22. Seydel, J. K. \& Schaper, K. J. Quantitative structure-pharmacokinetic relationships and drug design. Pharmacol. Ther. 15, 131-182, (1981).

23. Zhang, X.-D. et al. Size-dependent in vivo toxicity of PEG-coated gold nanoparticles. Int. J. Nanomedicine. 6, 2071-2081, (2011).

24. Sibrian-Vazquez, M., Escobedo, J. O., Lowry, M. \& Strongin, R. M. Progress toward red and near-infrared (NIR) emitting saccharide sensors. Pure Appl. Chem. 84, 2443-2456, (2012). 
25. Sibrian-Vazquez, M., Escobedo, J. O., Lowry, M., Fronczek, F. R. \& Strongin, R. M. Field effects induce bathochromic shifts in xanthene dyes. J. Am. Chem. Soc. 134, 10502-10508, (2012).

26. Yang, Y. et al. Seminaphthofluorones are a family of water-soluble, low molecular weight, NIR-emitting fluorophores. Proc. Natl. Acad. Sci. U. S. A. 105, 8829-8834, (2008).

27. Yang, Y. et al. An organic white light-emitting fluorophore. J. Am. Chem. Soc. 128, 14081-14092, (2006).

28. Owens, E. A., Hyun, H., Tawney, J. G., Choi, H. S. \& Henary, M. Correlating molecular character of NIR imaging agents with tissue-specific uptake. J. Med. Chem. 58, 4348-4356, (2015).

29. Lipinski, C. A., Lombardo, F., Dominy, B. W. \& Feeney, P. J. Experimental and computational approaches to estimate solubility and permeability in drug discovery and development settings. Adv. Drug Delivery. Rev. 23, 3-25, (1997).

30. Veber, D. F. et al. Molecular properties that influence the oral bioavailability of drug candidates. J. Med. Chem. 45, 2615-2623, (2002).

31. Chen, L. B. Mitochondrial Membrane Potential in Living Cells. Annu. Rev. Cell Biol. 4, 155-181, (1988).

32. Wada, H. et al. Pancreas-targeted NIR fluorophores for dual-channel image-guided abdominal surgery. Theranostics 5, 1-11, (2015).

33. Guerra, C. \& Barbacid, M. Genetically engineered mouse models of pancreatic adenocarcinoma. Mol. Oncol. 7, 232-247, (2013).

34. di Magliano, M. P. \& Logsdon, C. D. Roles for KRAS in pancreatic tumor development and progression. Gastroenterology 144, 1220-1229, (2013).

35. Hingorani, S. R. et al. Preinvasive and invasive ductal pancreatic cancer and its early detection in the mouse. Cancer Cell 4, 437-450, (2003).

36. Bardeesy, N. \& DePinho, R. A. Pancreatic cancer biology and genetics. Nat. Rev. Cancer 2, 897, (2002).

37. Liou, G.-Y. et al. Protein kinase D1 drives pancreatic acinar cell reprogramming and progression to intraepithelial neoplasia. Nat. Commun. 6, 6200, (2015). 
38. Shi, G. et al. Maintenance of acinar cell organization is critical to preventing Krasinduced acinar-ductal metaplasia. Oncogene 32, 1950-1958, (2013).

39. Perera, Rushika M. \& Bardeesy, N. Ready, Set, Go: The EGF Receptor at the Pancreatic Cancer Starting Line. Cancer cell. 22, 281-282, (2012).

40. De La O, J.-P. et al. Notch and Kras reprogram pancreatic acinar cells to ductal intraepithelial neoplasia. Proc. Natl. Acad. Sci. USA. 105, 18907-18912, (2008).

41. Antonucci, L. et al. Basal autophagy maintains pancreatic acinar cell homeostasis and protein synthesis and prevents ER stress. Proc. Natl. Acad. Sci. USA. 112, E6166-E6174 (2015).

42. Ouaissi, M. et al. Ductal adenocarcinoma of the pancreatic head: a focus on current diagnostic and surgical concepts. World J. Gastroenterol. 18, 3058-3069, (2012).

43. Sohn, T. A. et al. Resected adenocarcinoma of the pancreas-616 patients: results, outcomes, and prognostic indicators. J. Gastrointest. Surg. 4, 567-579, (2000).

44. Conlon, K. C., Klimstra, D. S. \& Brennan, M. F. Long-term survival after curative resection for pancreatic ductal adenocarcinoma: Clinicopathologic analysis of 5year survivors. Ann. Surg. 223, 273-279, (1996).

45. Chang, D. K. et al. Margin clearance and outcome in resected pancreatic cancer. $J$. Clin. Oncol. 27, 2855-2862, (2009).

46. Olafsen, T. et al. Optimizing Radiolabeled Engineered Anti-p185HER2 Antibody Fragments for In vivo Imaging. Cancer Res. 65, 5907-5916, (2005).

47. Kaur, S. et al. Recent trends in antibody-based oncologic imaging. Cancer Lett. 315, 97-111, (2012).

48. Wu, A. M. \& Olafsen, T. Antibodies for molecular imaging of cancer. Cancer J. 14, 191-197, (2008).

49. Trajkovic-Arsic, M. et al. Multimodal molecular imaging of integrin alphavbeta3 for in vivo detection of pancreatic cancer. J. Nucl. Med. 55, 446-451, (2014).

50. Stangl, S. et al. Selective in vivo imaging of syngeneic, spontaneous, and xenograft tumors using a novel tumor cell-specific hsp70 peptide-based probe. Cancer Res. 74, 6903-6912, (2014).

51. Neesse, A. et al. Claudin-4-targeted optical imaging detects pancreatic cancer and its precursor lesions. Gut 62, 1034-1043, (2013). 
52. Keliher, E. J. et al. Targeting cathepsin $\mathrm{E}$ in pancreatic cancer by a small molecule allows in vivo detection. Neoplasia 15, 684-693, (2013).

53. Cruz-Monserrate, Z. et al. Detection of pancreatic cancer tumours and precursor lesions by cathepsin E activity in mouse models. Gut 61, 1315-1322, (2012).

54. Eser, S. et al. In vivo diagnosis of murine pancreatic intraepithelial neoplasia and early-stage pancreatic cancer by molecular imaging. Proc. Natl. Acad. Sci. U. S. A. 108, 9945-9950, (2011).

55. Furukawa, H. et al. Clinicopathologic features of small pancreatic adenocarconoma: A collective study. Cancer 78, 986-990, (1996).

56. Hruban, R. H., Maitra, A. \& Goggins, M. Update on pancreatic intraepithelial neoplasia. Int. J. Clin. Exp. Pathol. 1, 306-316, (2008).

57. Viale, A. et al. Oncogene ablation-resistant pancreatic cancer cells depend on mitochondrial function. Nature 514, 628-632, (2014).

58. Hashim, Y. M. et al. Targeted pancreatic cancer therapy with the small molecule drug conjugate SW IV-134. Mol. Oncol. 8, 956-967, (2014).

59. Millard, M., Gallagher, J. D., Olenyuk, B. Z. \& Neamati, N. A selective mitochondrial-targeted chlorambucil with remarkable cytotoxicity in breast and pancreatic cancers. J. Med. Chem. 56, 9170-9179, (2013).

60. Sicard, F., Gayral, M., Lulka, H., Buscail, L. \& Cordelier, P. Targeting miR-21 for the therapy of pancreatic cancer. Mol. Ther. 21, 986-994, (2013).

61. Gaussian 09 v. D.01 (Gaussian, Inc., Wallingford, CT, USA, 2009).

62. Tuveson, D. A. \& Hingorani, S. R. Ductal pancreatic cancer in humans and mice. Cold. Spring. Harb. Symp. Quant. Biol. 70, 65-72, (2005).

63. Hingorani, S. R. et al. Preinvasive and invasive ductal pancreatic cancer and its early detection in the mouse. Cancer Cell 4, 437-450, (2003).

64. Jackson, E. L. et al. Analysis of lung tumor initiation and progression using conditional expression of oncogenic K-ras. Genes Dev. 15, 3243-3248, (2001).

65. Kawaguchi, Y. et al. The role of the transcriptional regulator Ptf1a in converting intestinal to pancreatic progenitors. Nat. Genet. 32, 128-134, (2002).

66. Wang, X. et al. Phosphorylation regulates c-Myc's oncogenic activity in the mammary gland. Cancer Res. 71, 925-936, (2011). 


\section{APPENDIX}

CHARACTERIZATION DATA
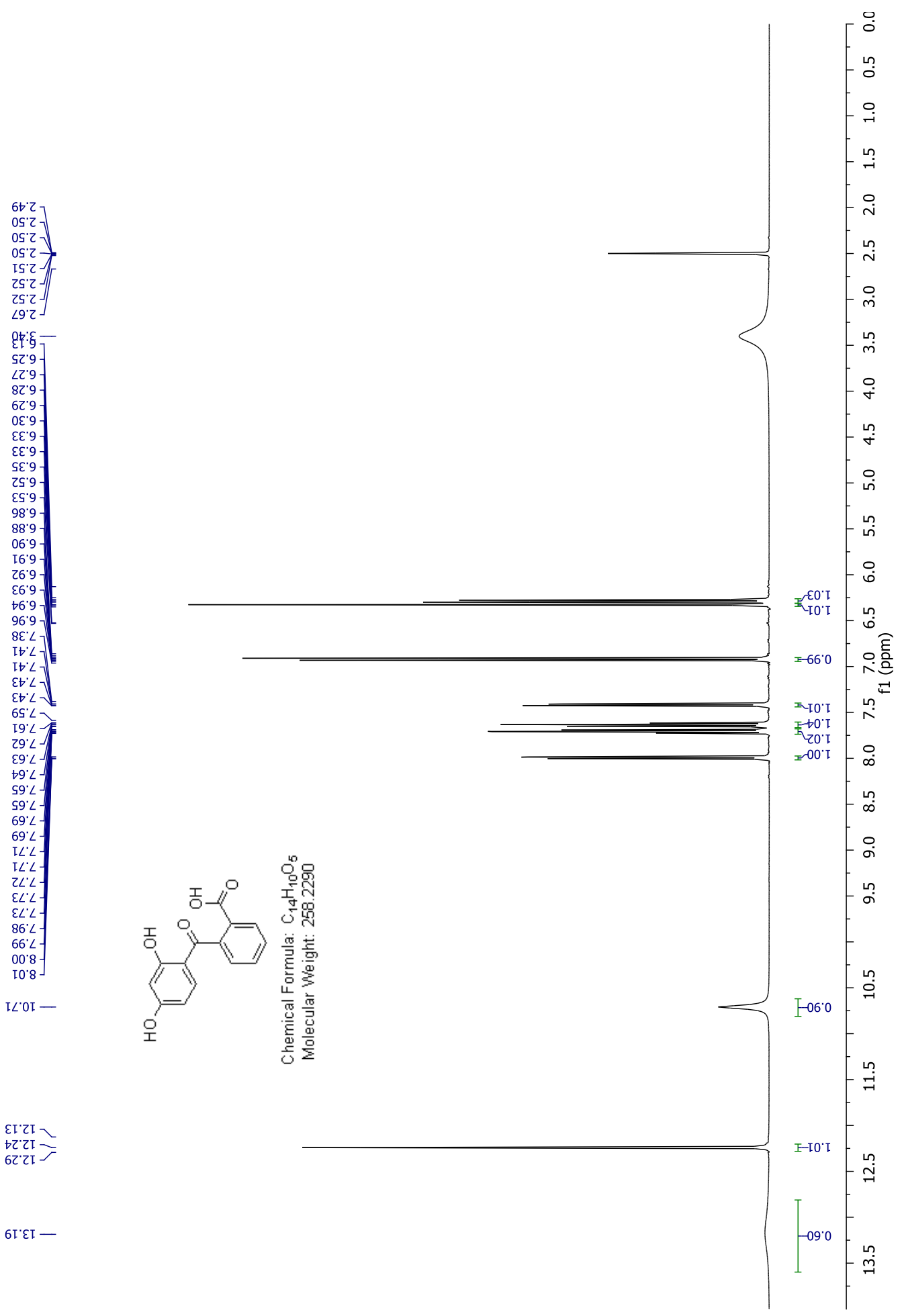

Figure A1 ${ }^{1} \mathrm{H}$ NMR spectrum of compound 15 


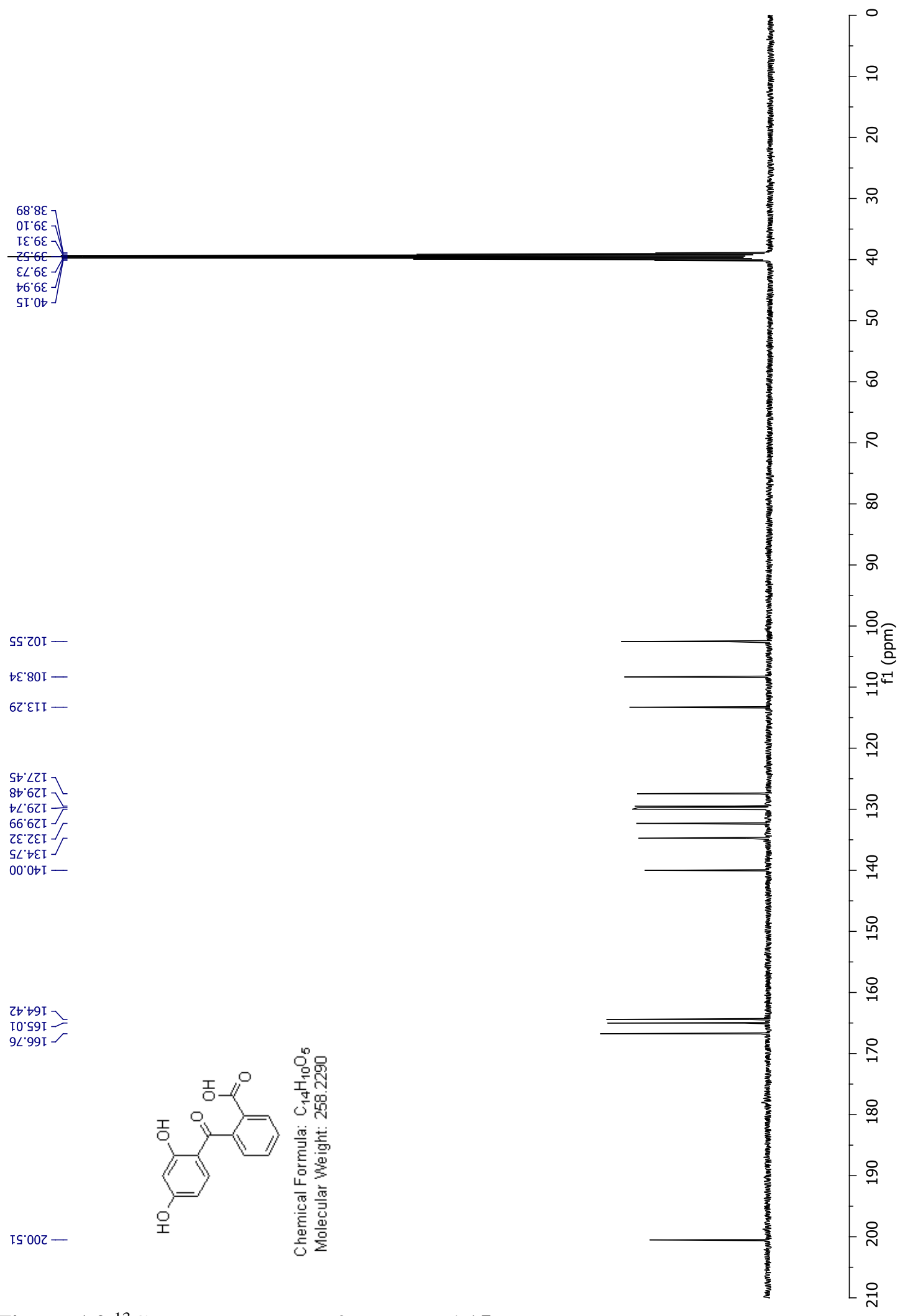

Figure A2 ${ }^{13} \mathrm{C}$ NMR spectrum of compound $\mathbf{1 5}$ 

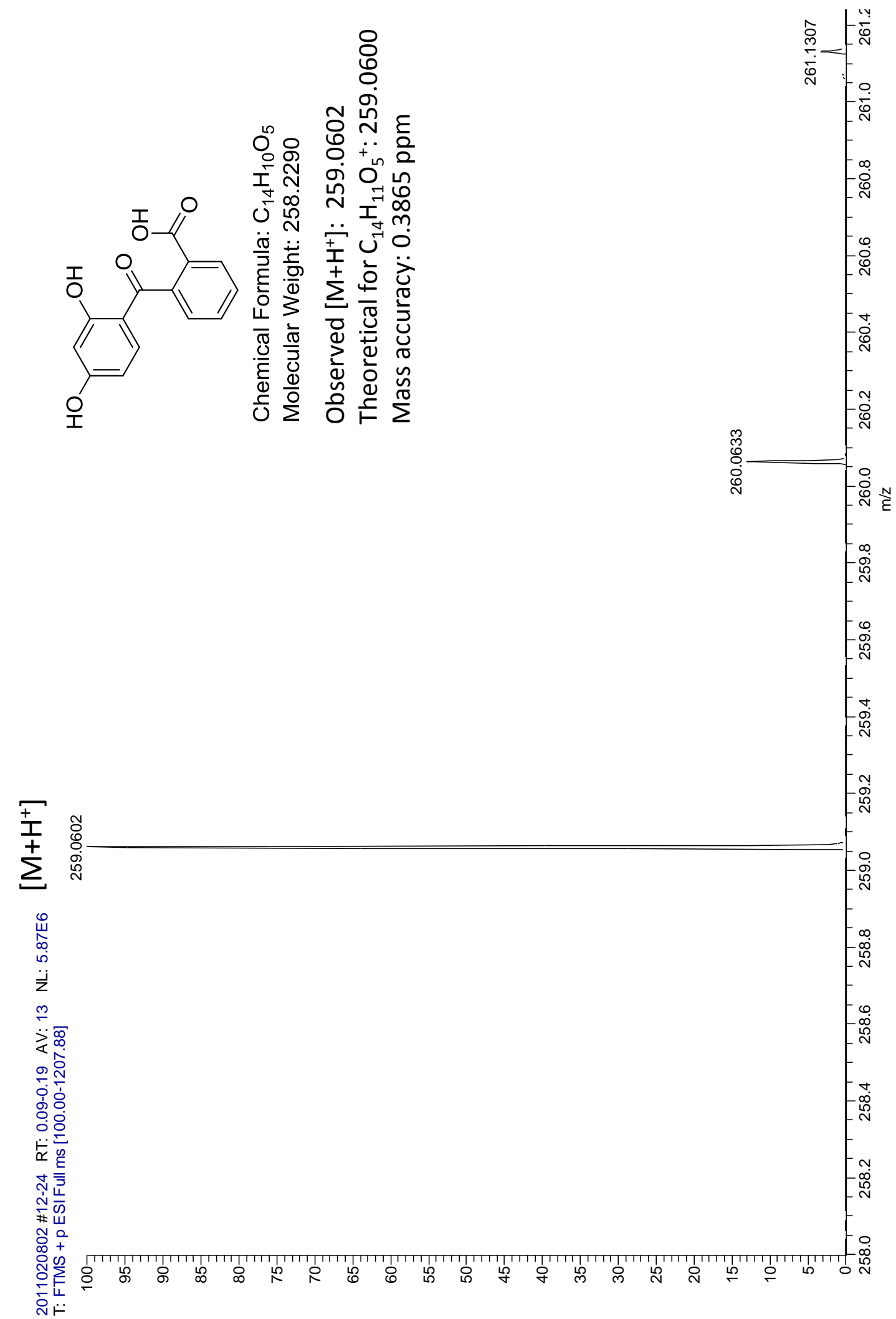

Figure A3 HR ESI positive mode spectrum of compound 15 


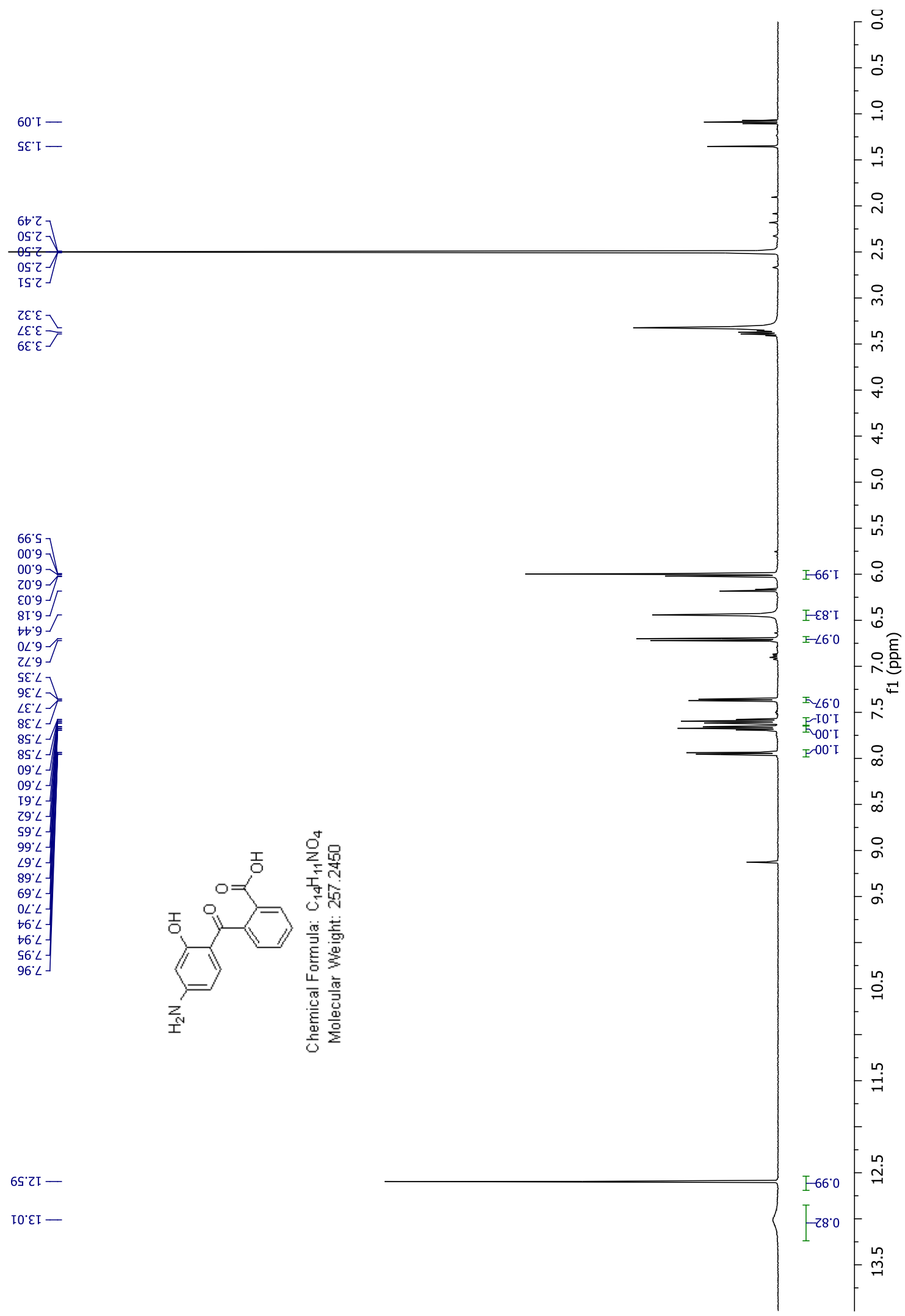

Figure A4 ${ }^{1} \mathrm{H}$ NMR spectrum of compound 17 


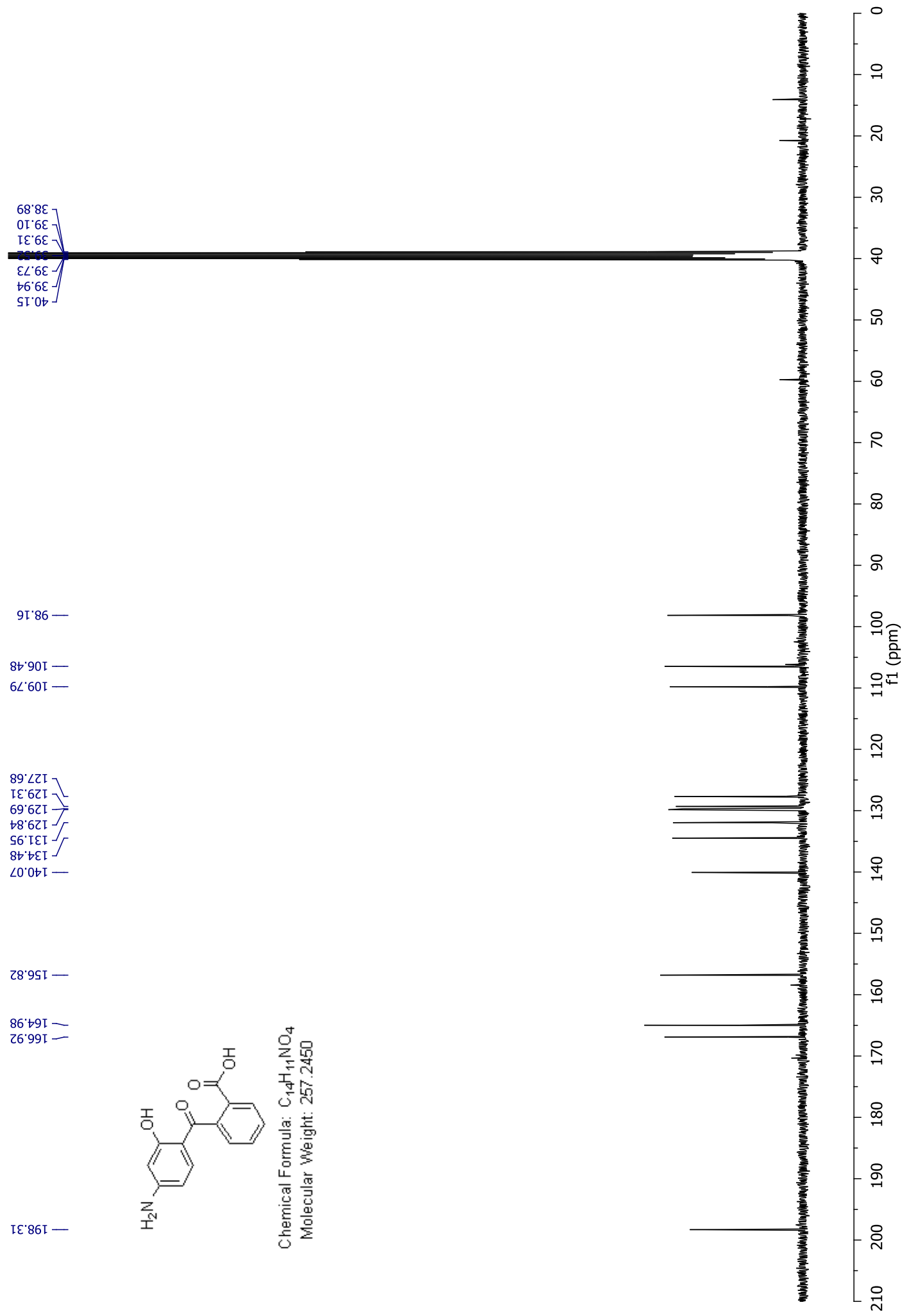

Figure A5 ${ }^{13} \mathrm{C}$ NMR spectrum of compound $\mathbf{1 7}$ 

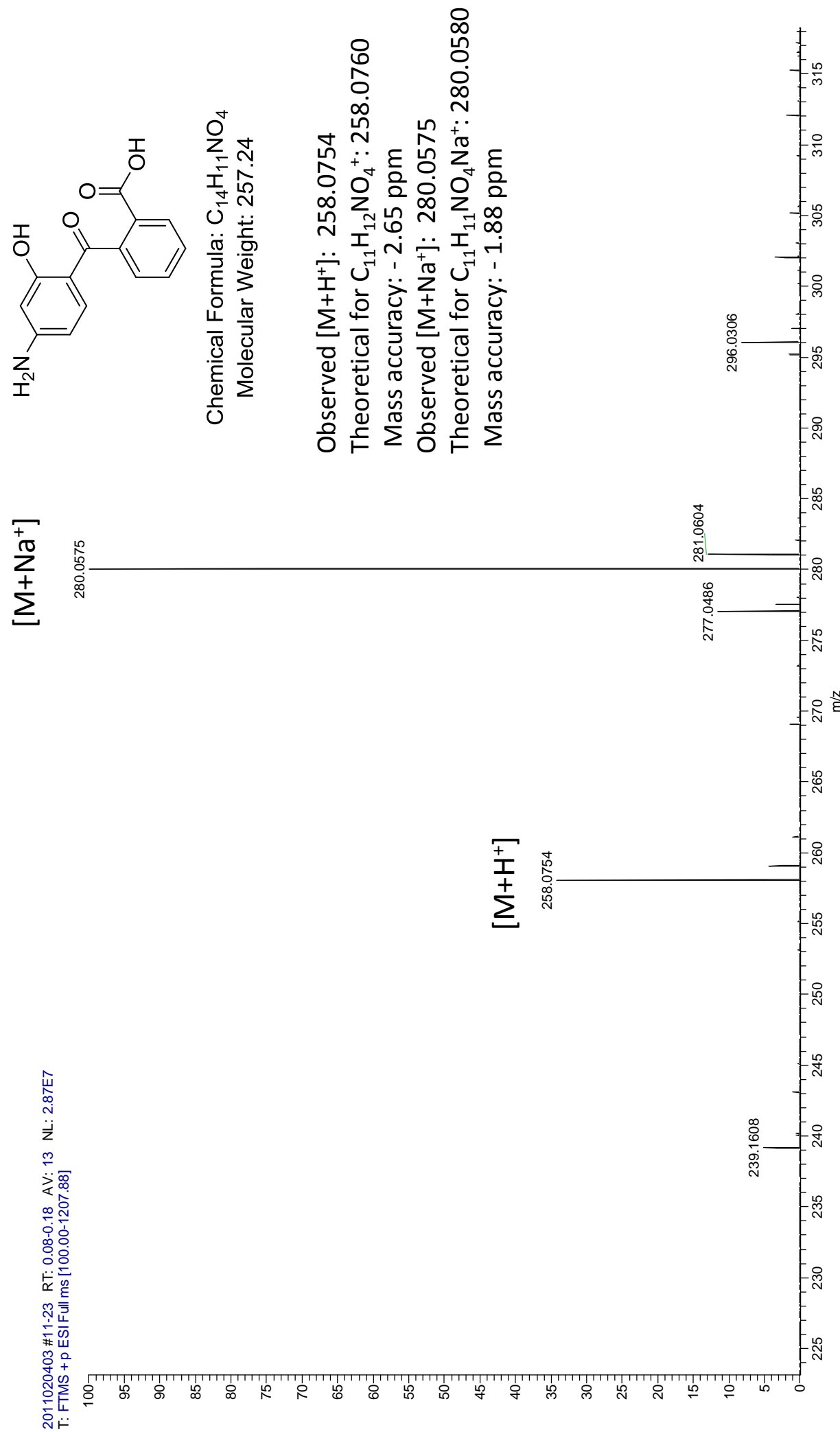

Figure A6 HR ESI positive mode spectrum of compound 17 


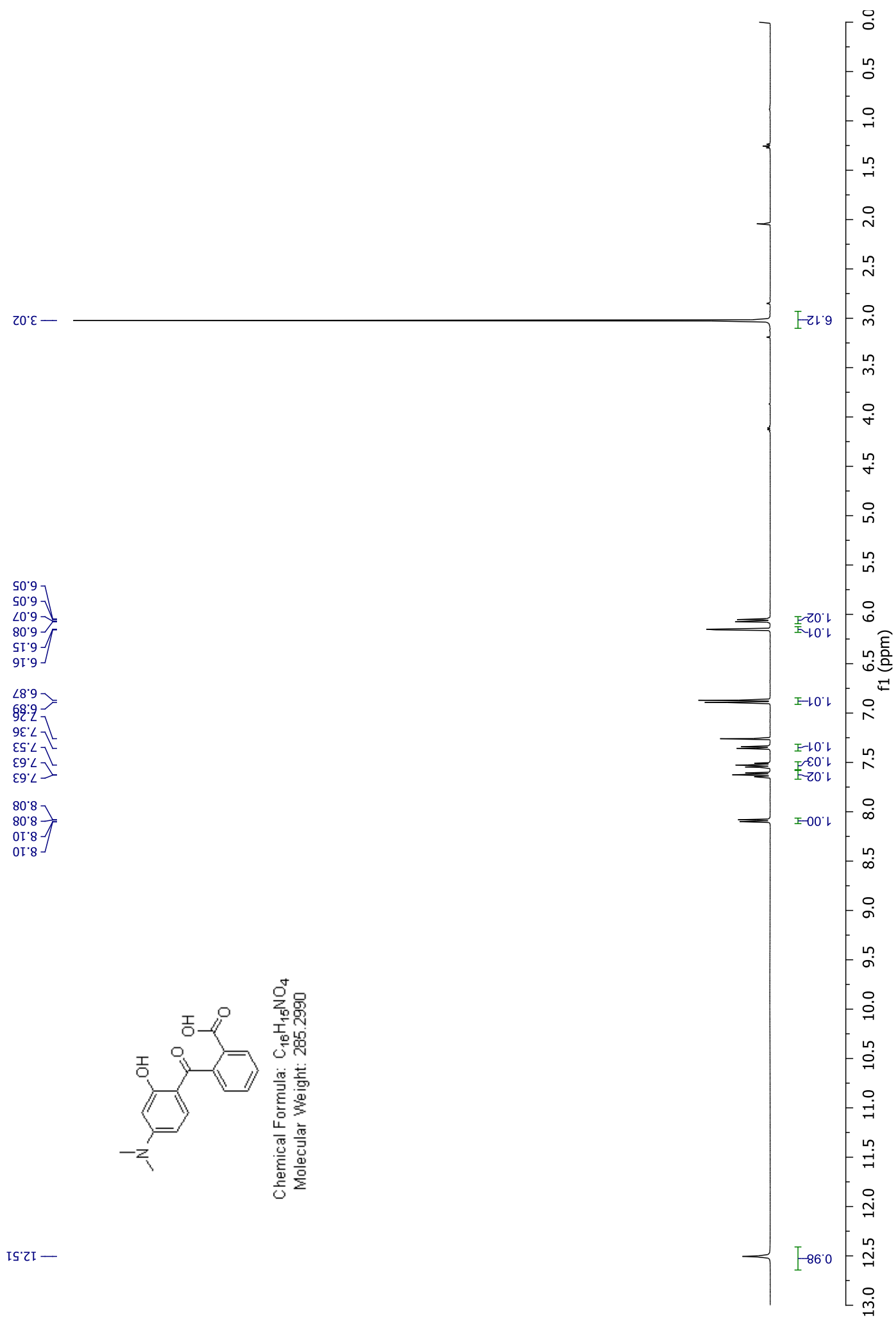

Figure A7 ${ }^{1} \mathrm{H}$ NMR spectrum of compound 20 

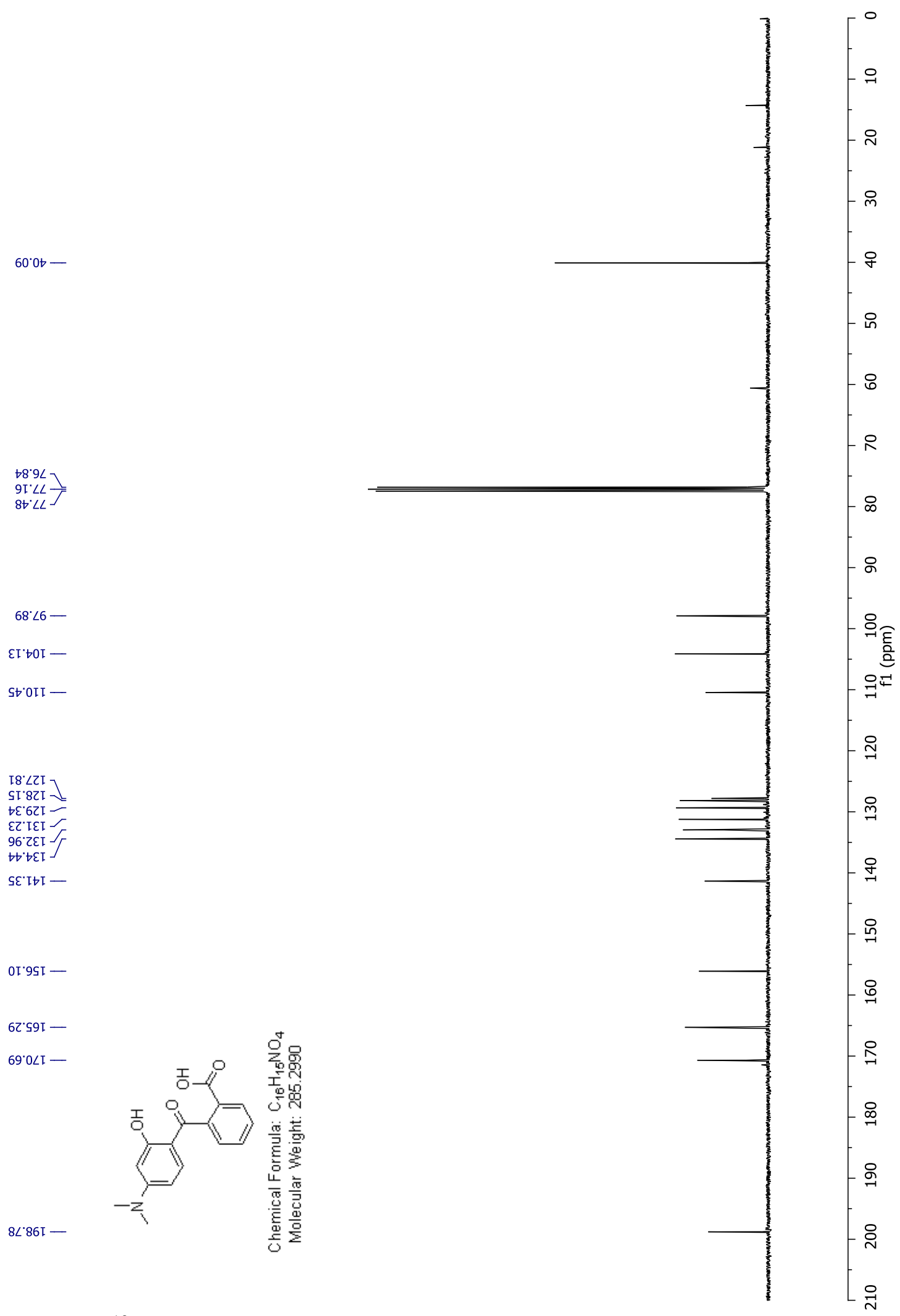

Figure $\mathbf{A 8}{ }^{13} \mathrm{C}$ NMR spectrum of compound 20 

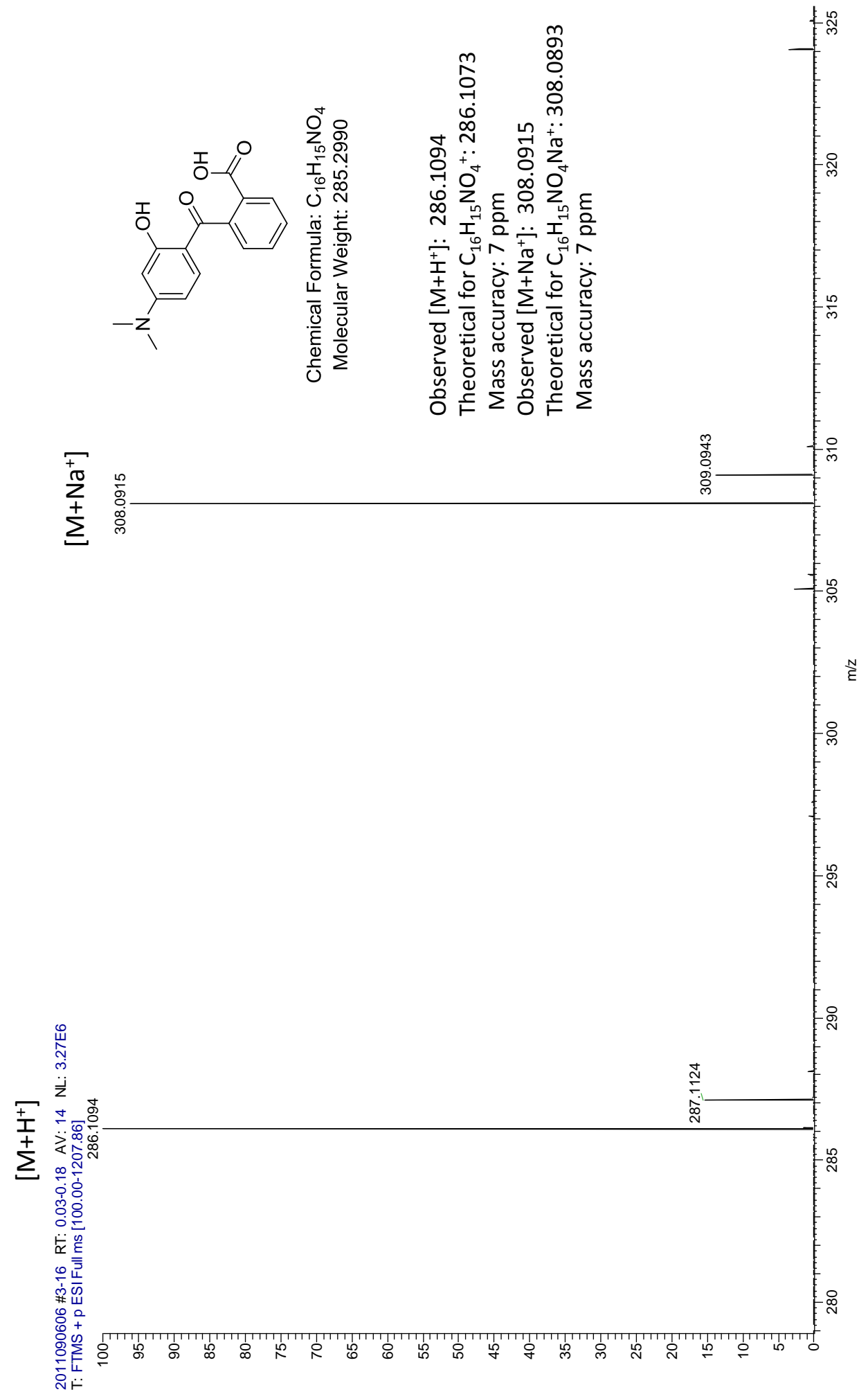

Figure A9 HR ESI positive mode spectrum of compound 20 

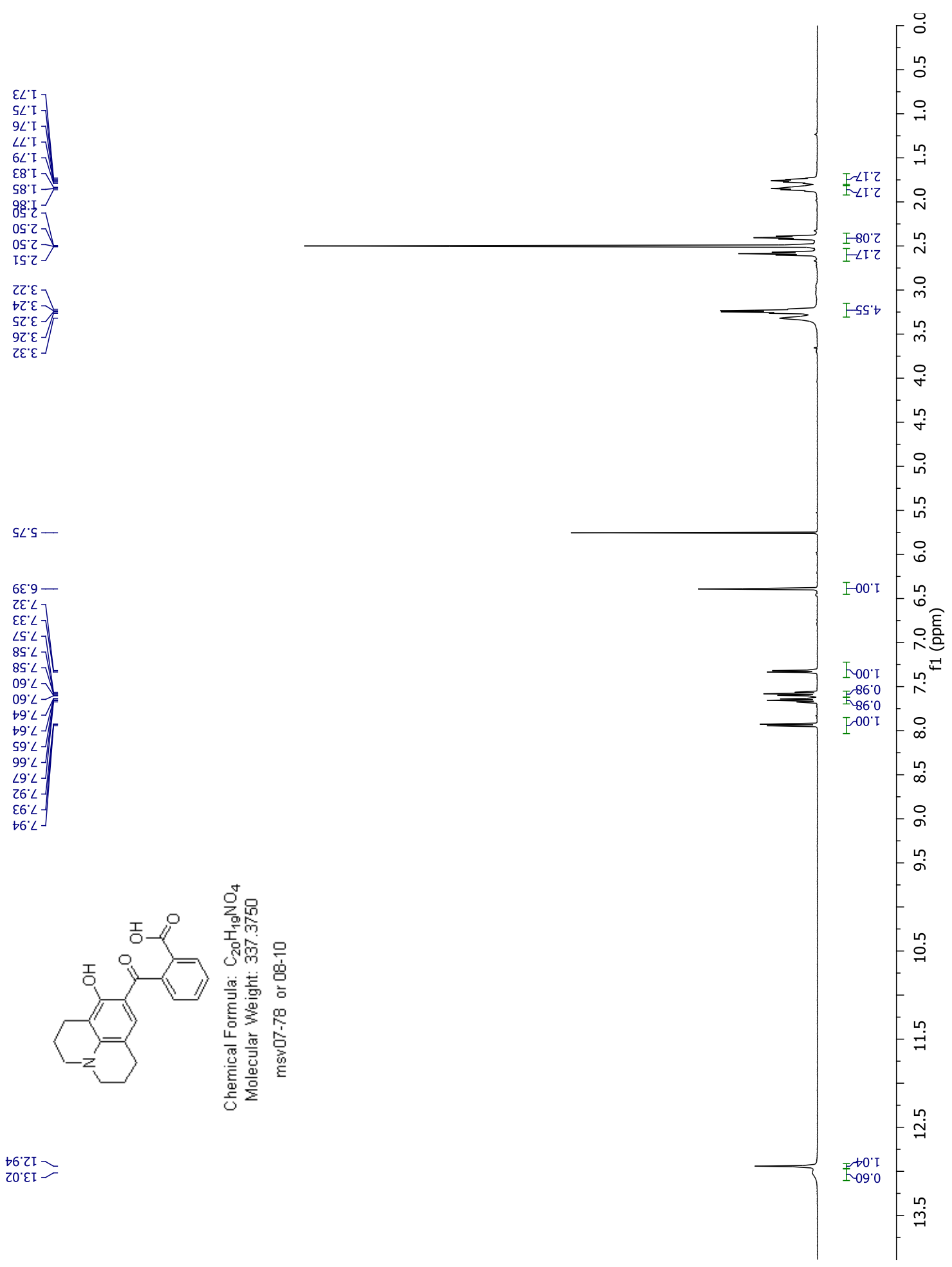

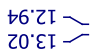

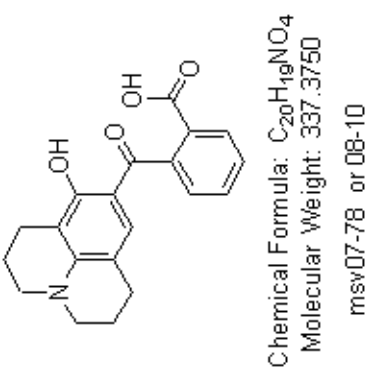

Figure A10 ${ }^{1} \mathrm{H}$ NMR spectrum of compound 22 


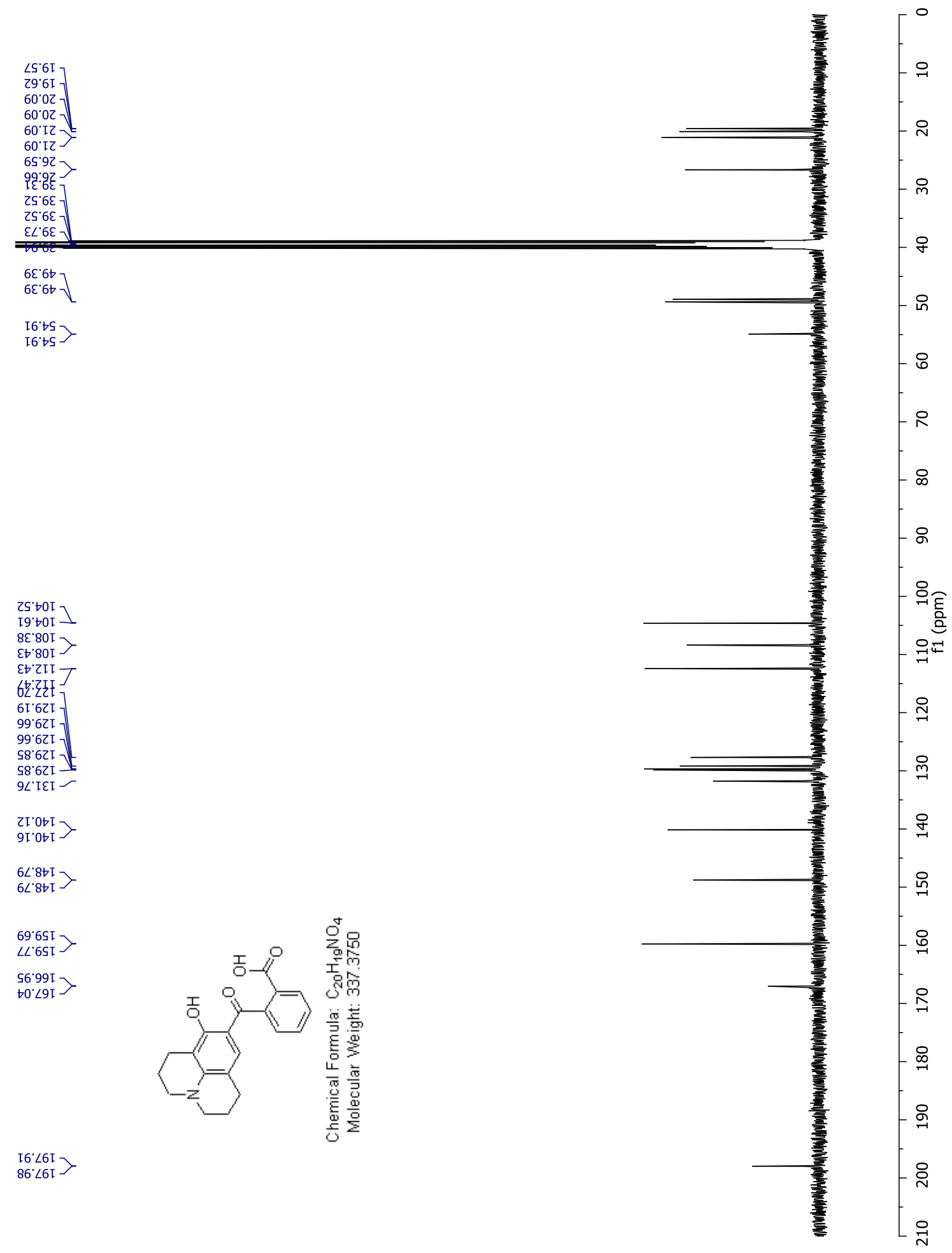

Figure A11 ${ }^{13} \mathrm{C}$ NMR spectrum of compound 22 

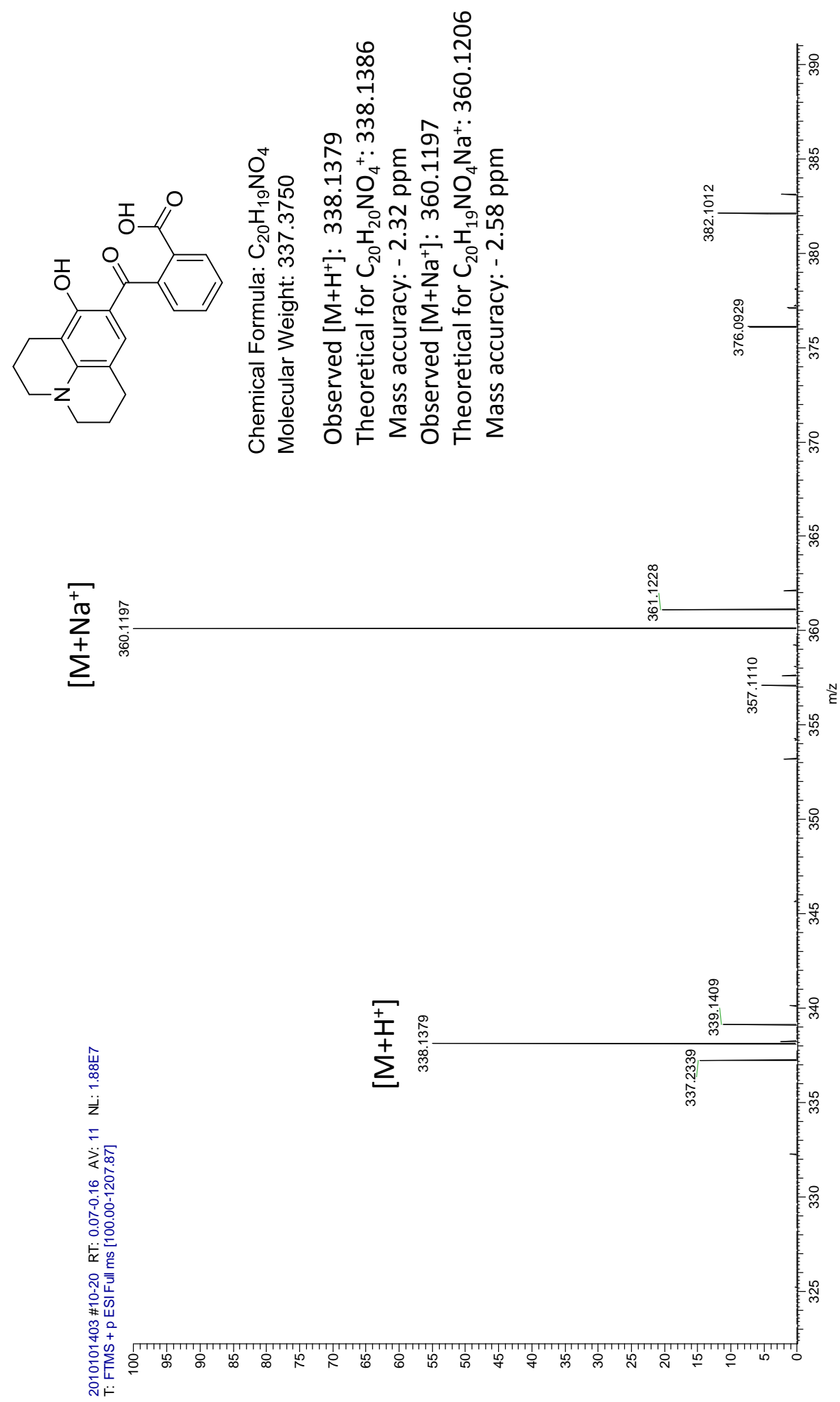

Figure A12 HR ESI positive mode spectrum of compound 22 


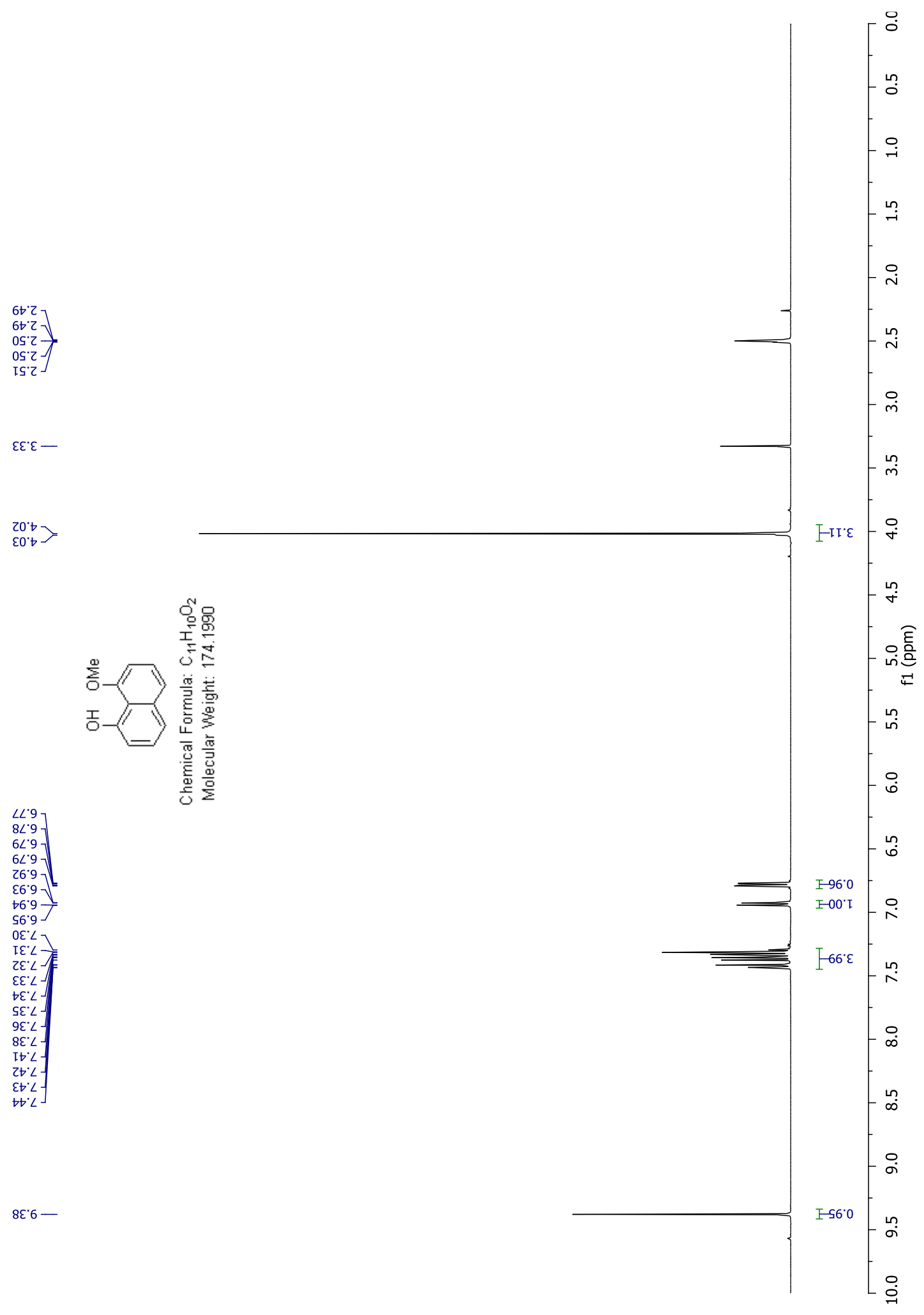

Figure A13 ${ }^{1} \mathrm{H}$ NMR spectrum of compound 24 


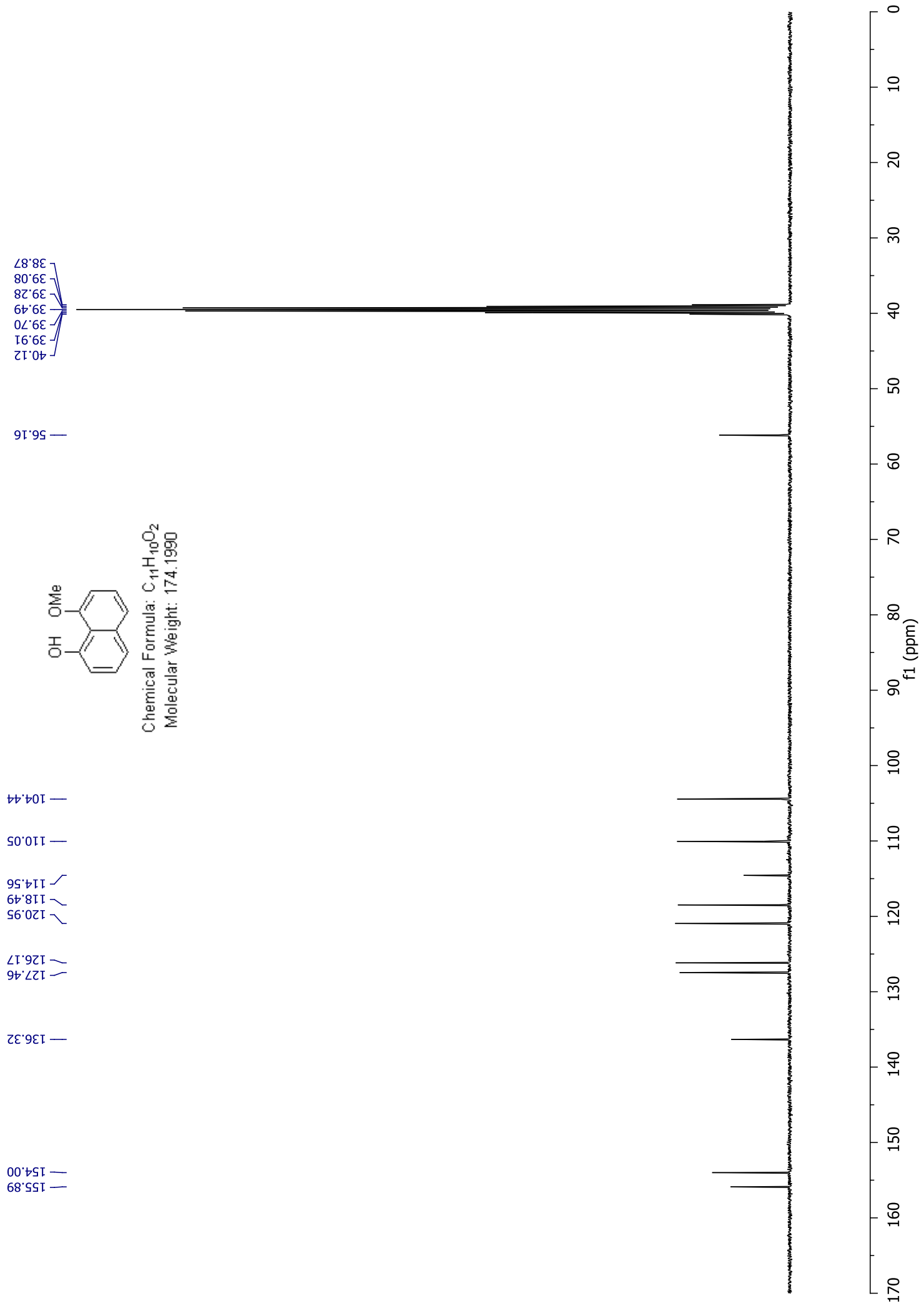

Figure A14 ${ }^{13} \mathrm{C}$ NMR spectrum of compound 24 


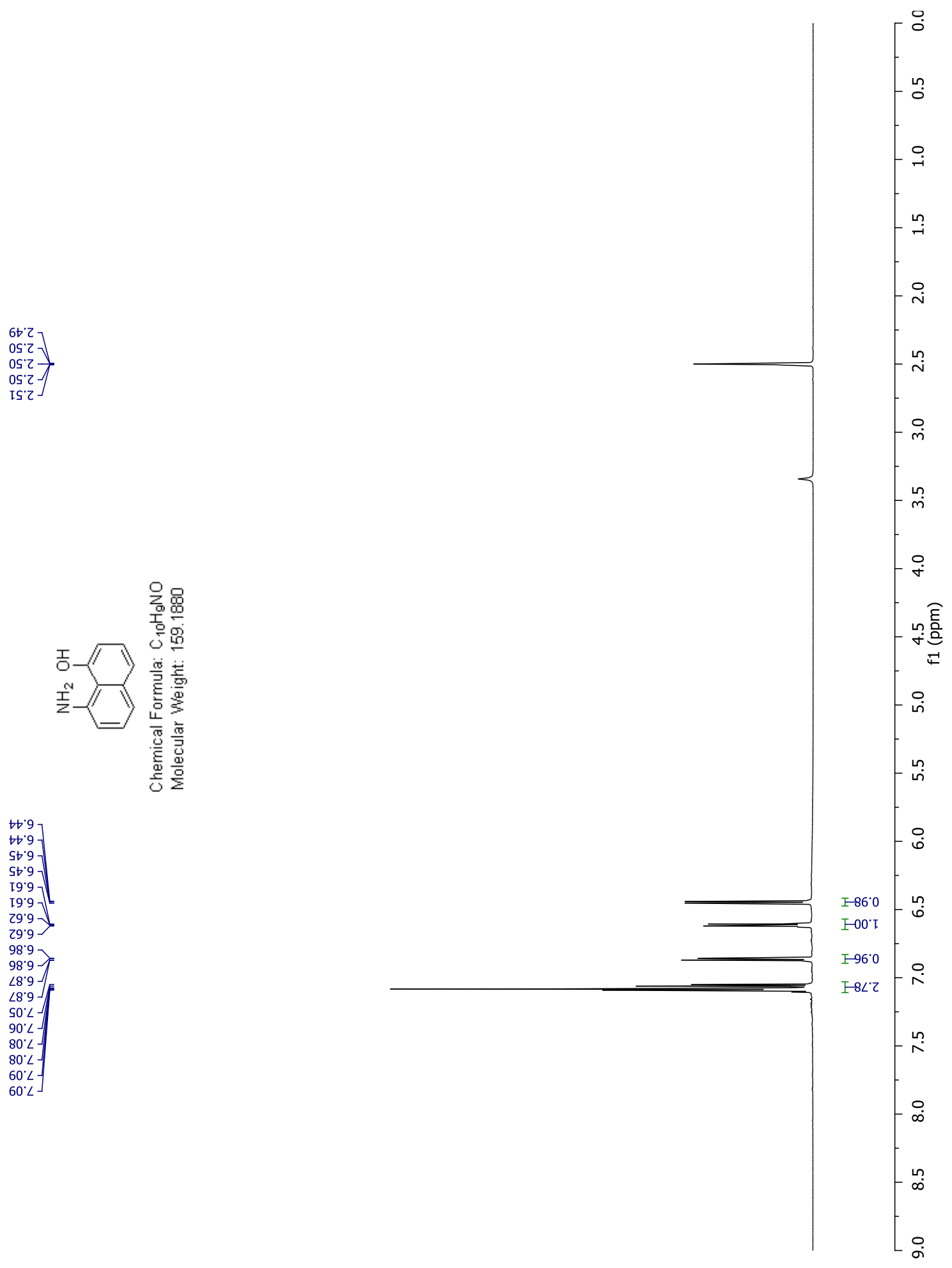

Figure A15 ${ }^{1} \mathrm{H}$ NMR spectrum of compound 26 


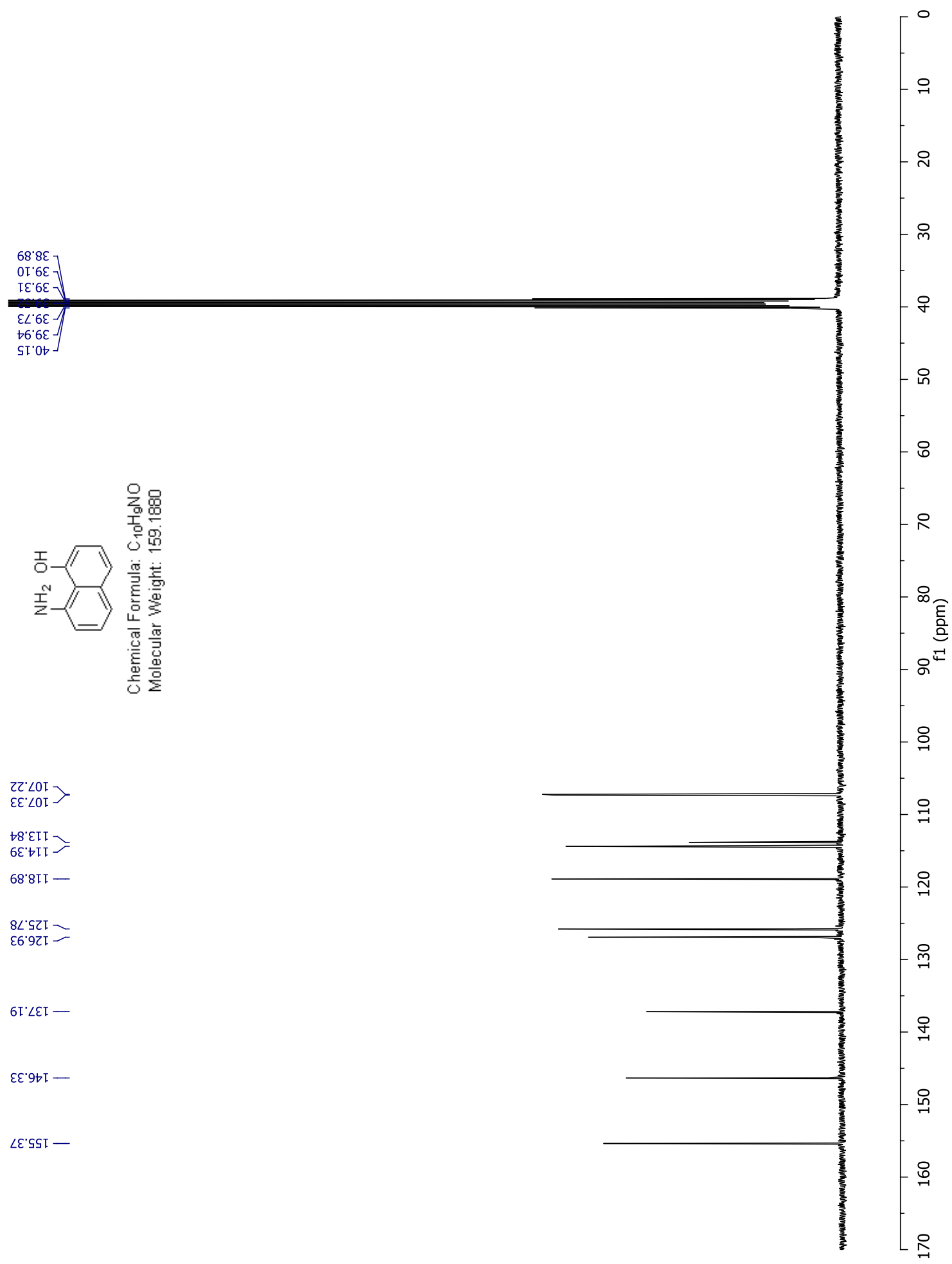

Figure A16 ${ }^{13} \mathrm{C}$ NMR spectrum of compound 26 


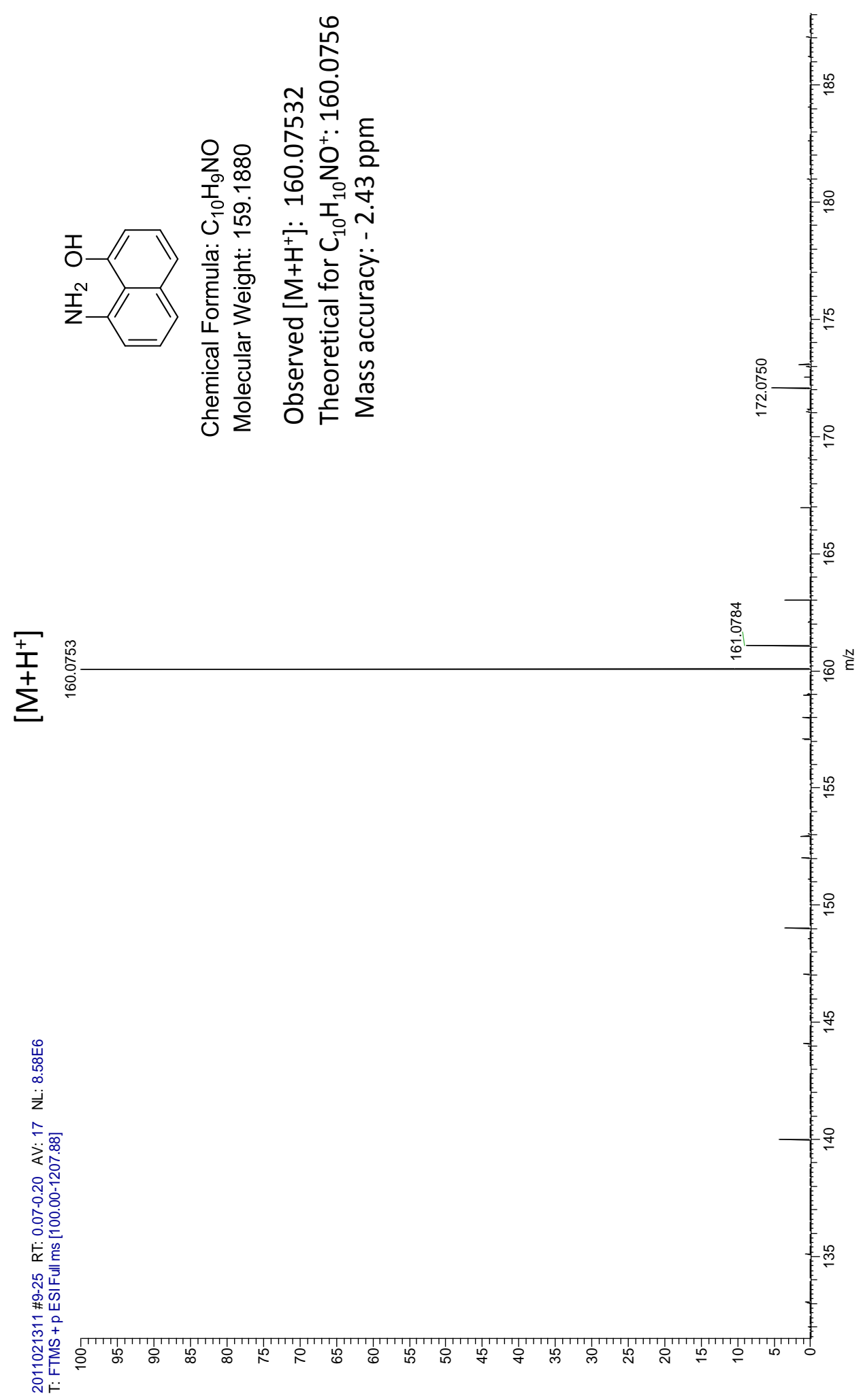

Figure A17 HR ESI positive mode spectrum of compound 26 


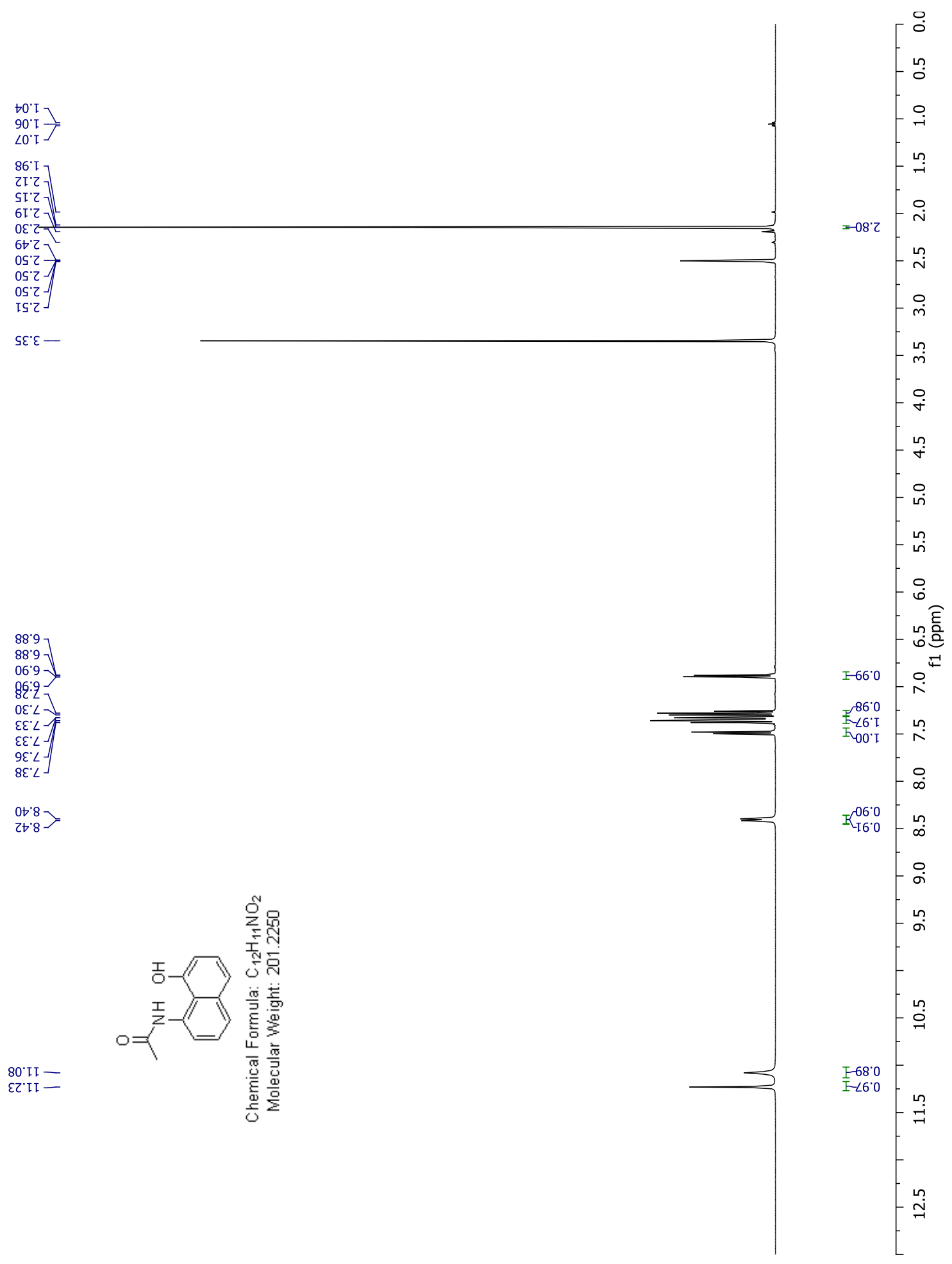

Figure A18 ${ }^{1} \mathrm{H}$ NMR spectrum of compound 28 


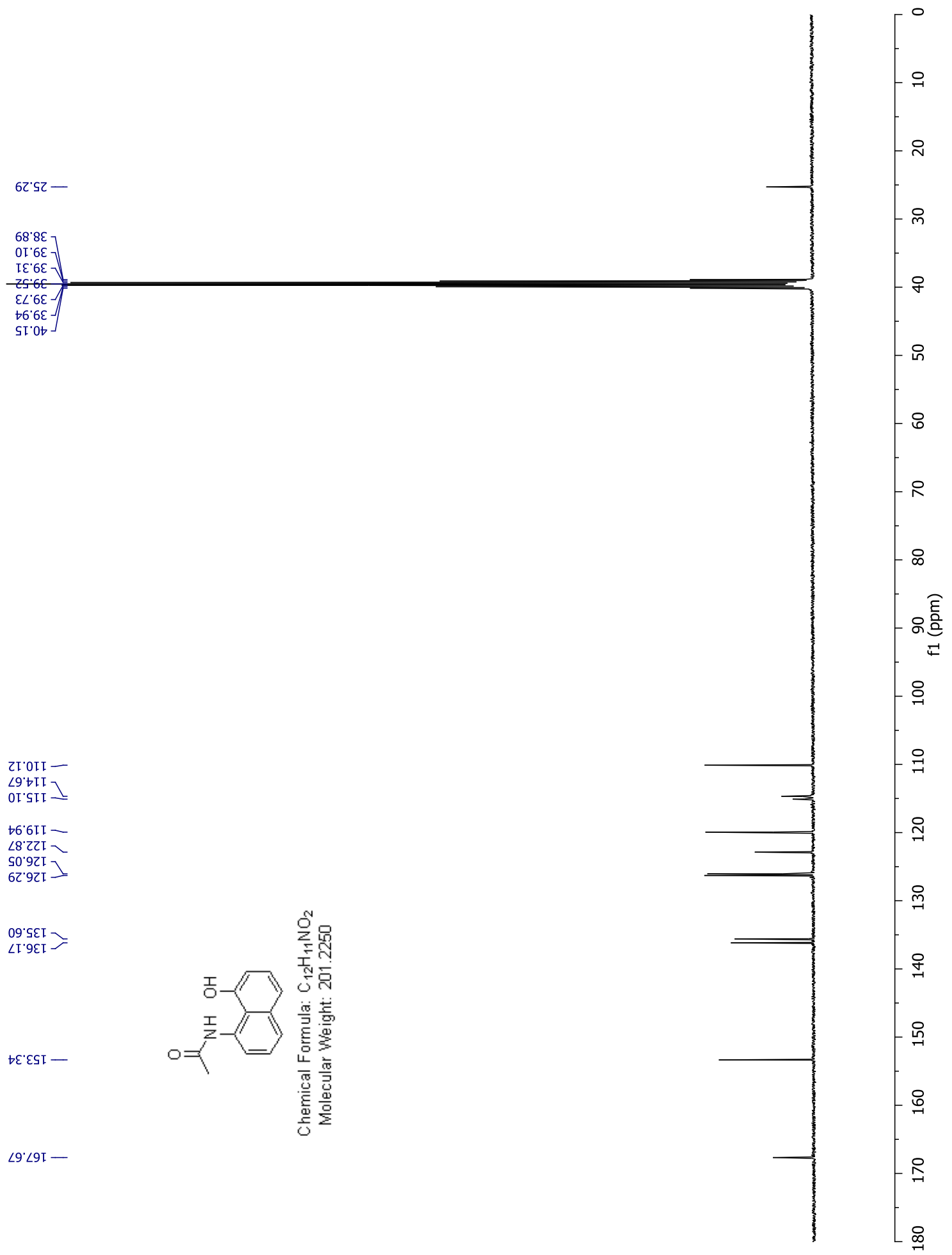

Figure A19 ${ }^{13} \mathrm{C}$ NMR spectrum of compound 28 


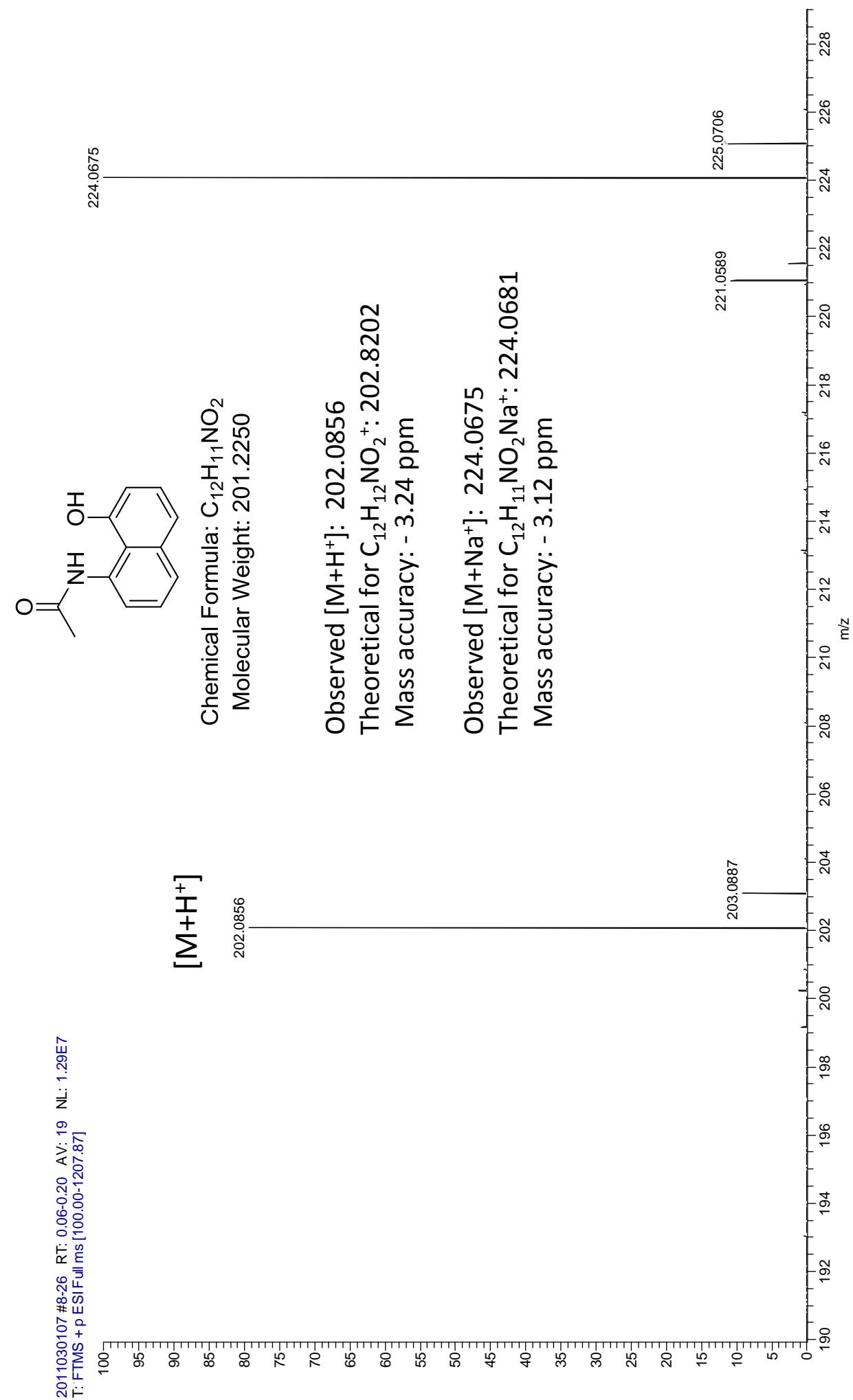

Figure A20 HR ESI positive mode spectrum of compound 28 


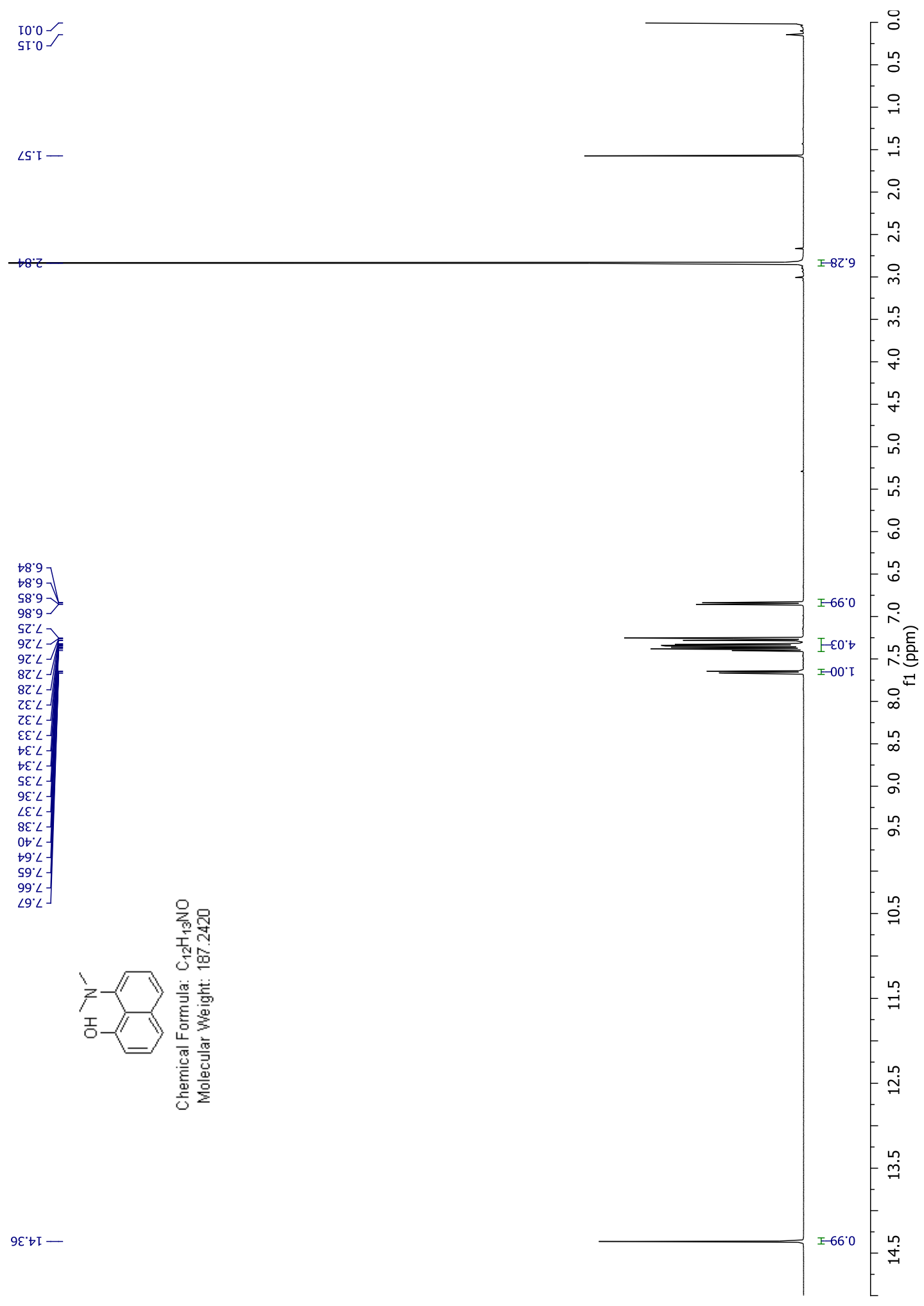

Figure A21 ${ }^{1} \mathrm{H}$ NMR spectrum of compound 31 


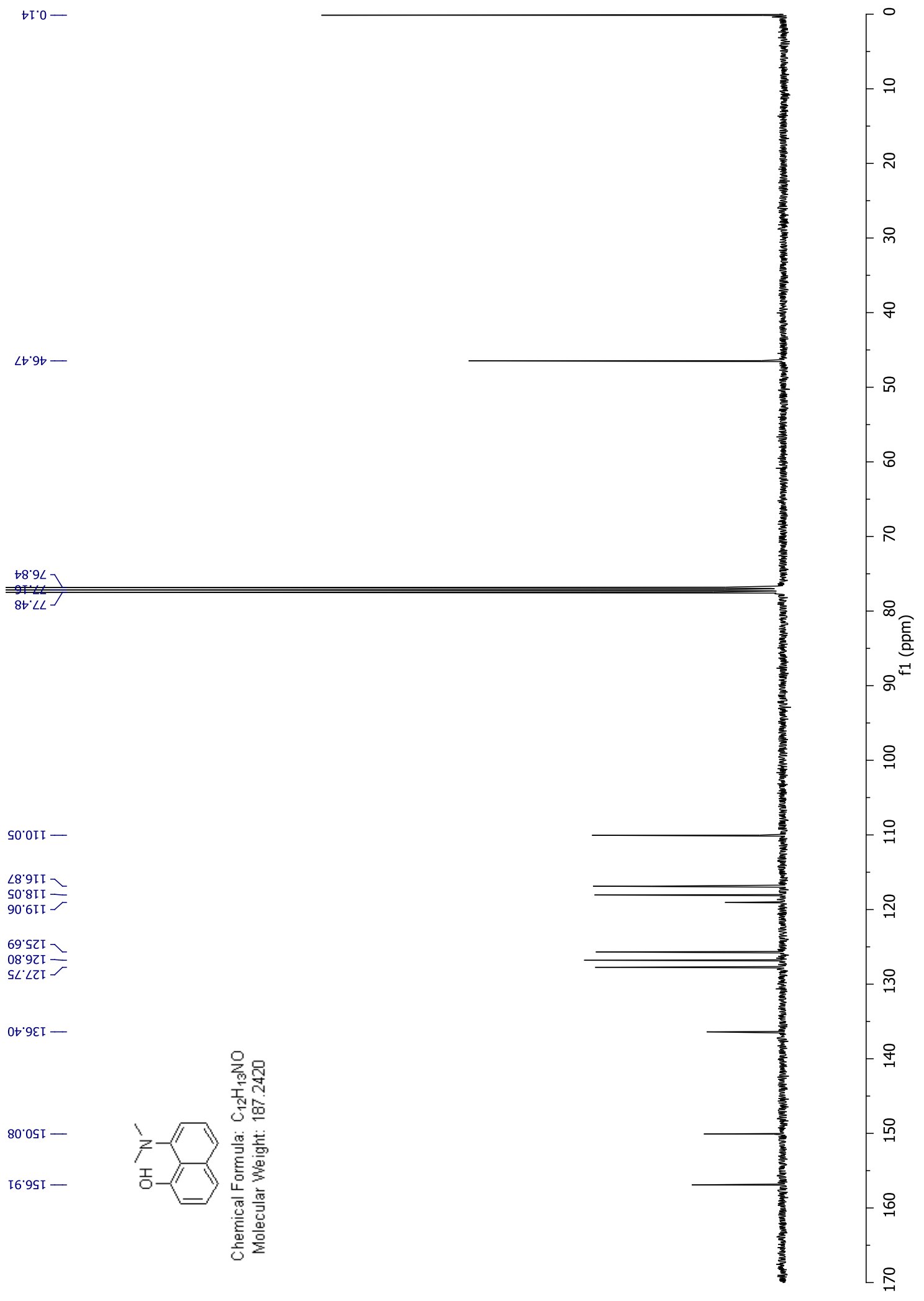

Figure A22 ${ }^{13} \mathrm{C}$ NMR spectrum of compound 31 


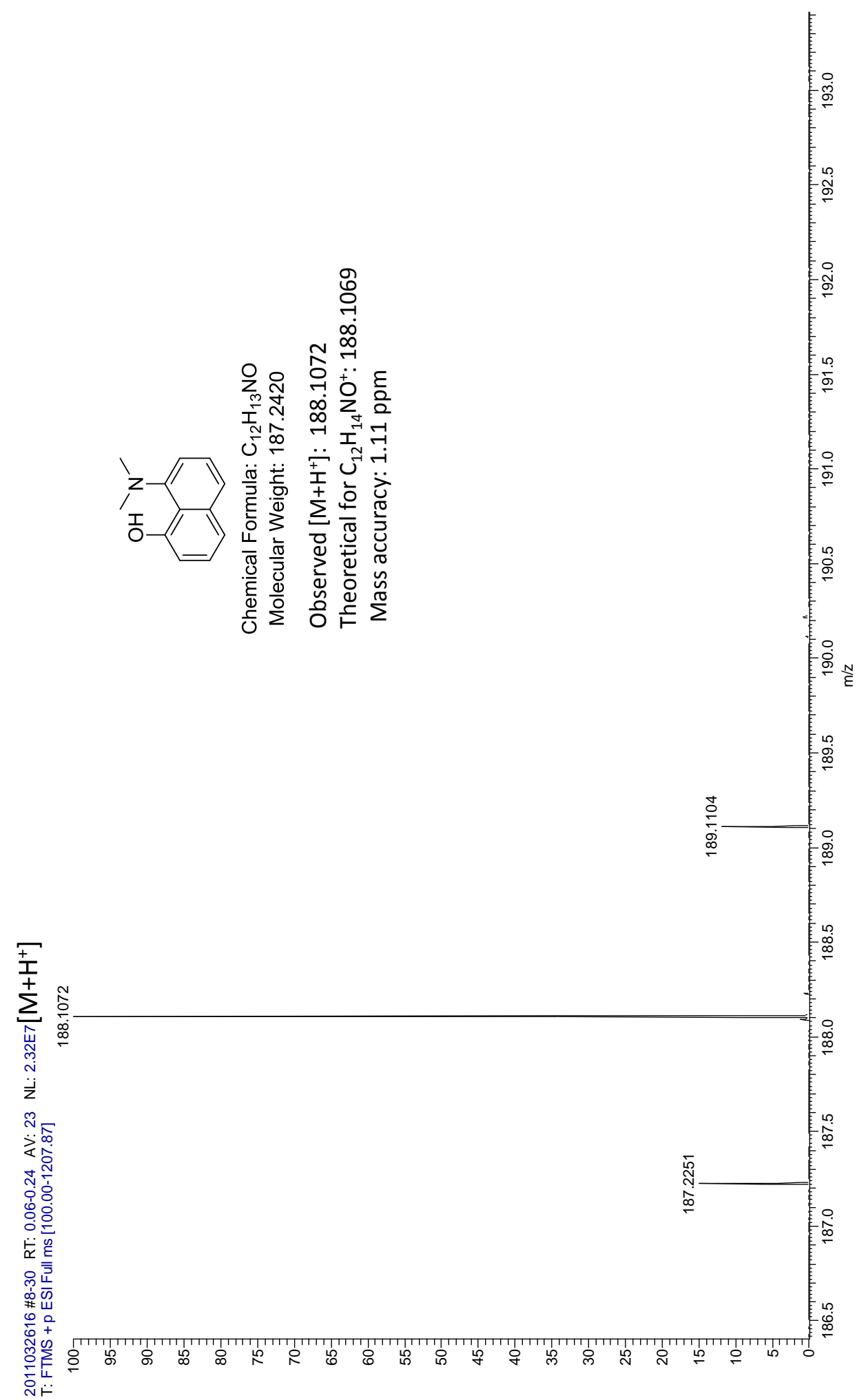

Figure A23 HR ESI positive mode spectrum of compound 31 


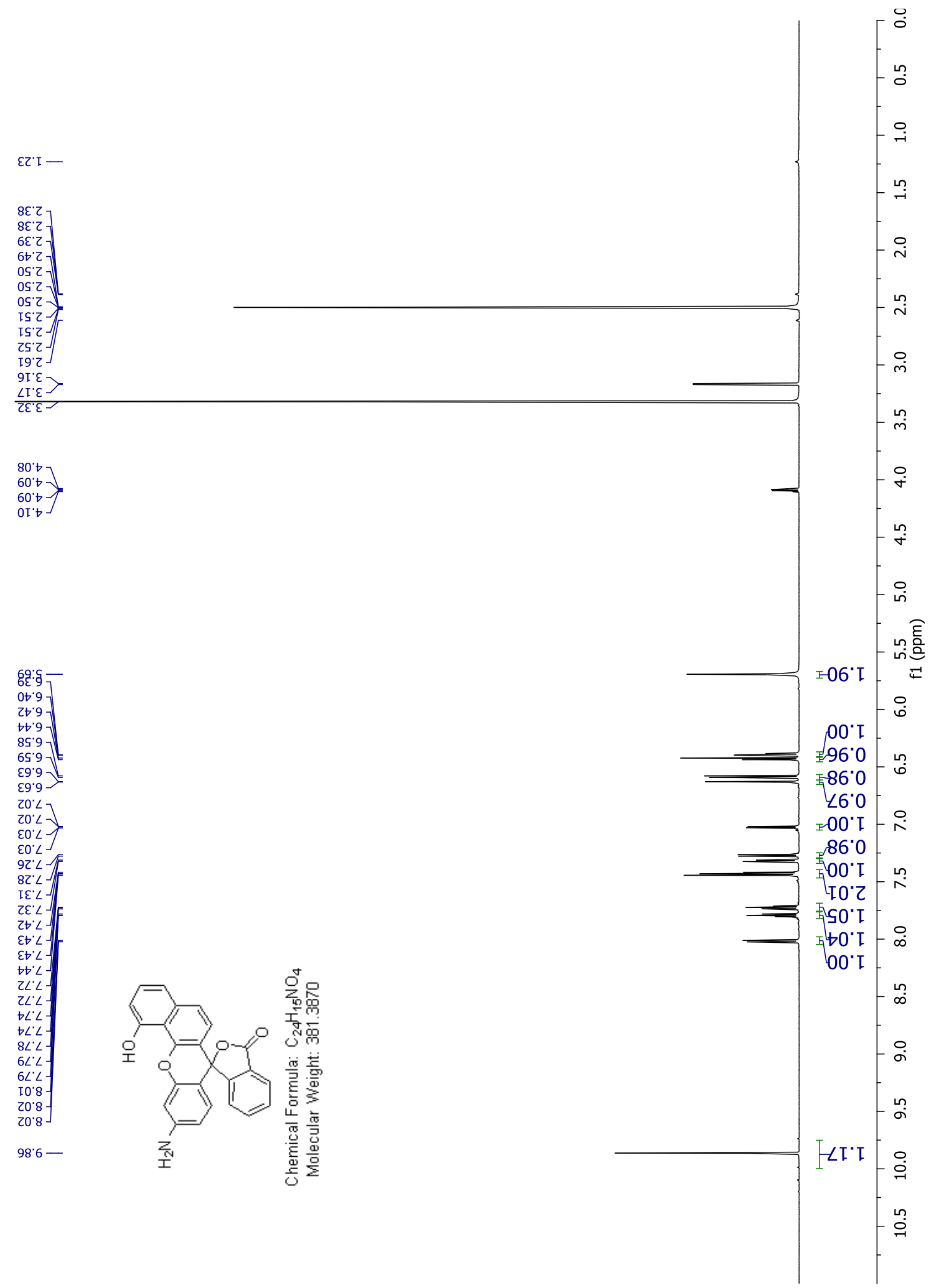

Figure A24 ${ }^{1} \mathrm{H}$ NMR spectrum of compound 32 


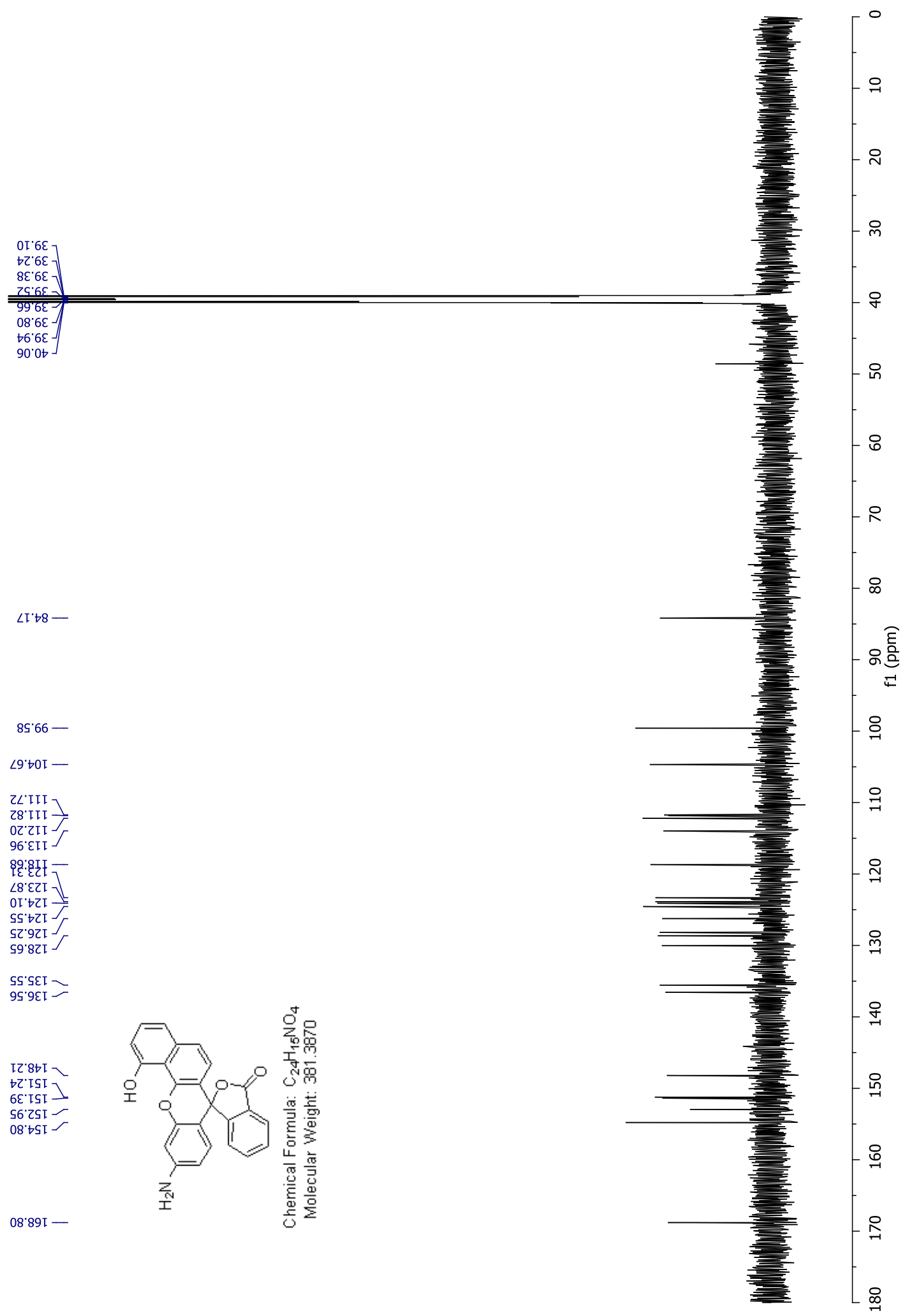

Figure A25 ${ }^{13} \mathrm{C}$ NMR spectrum of compound 32 

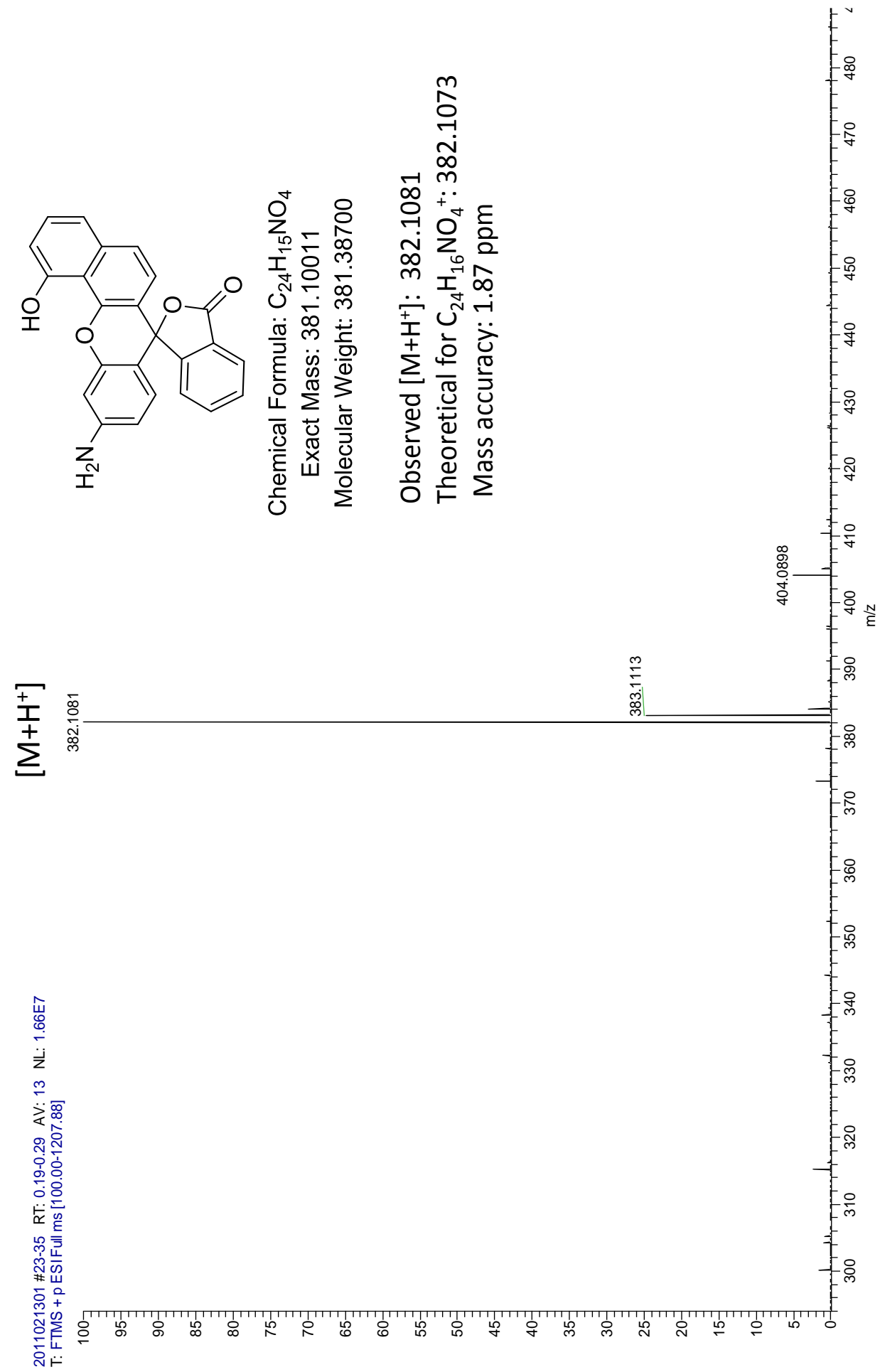

Figure A26 HR ESI positive mode spectrum of compound 31 


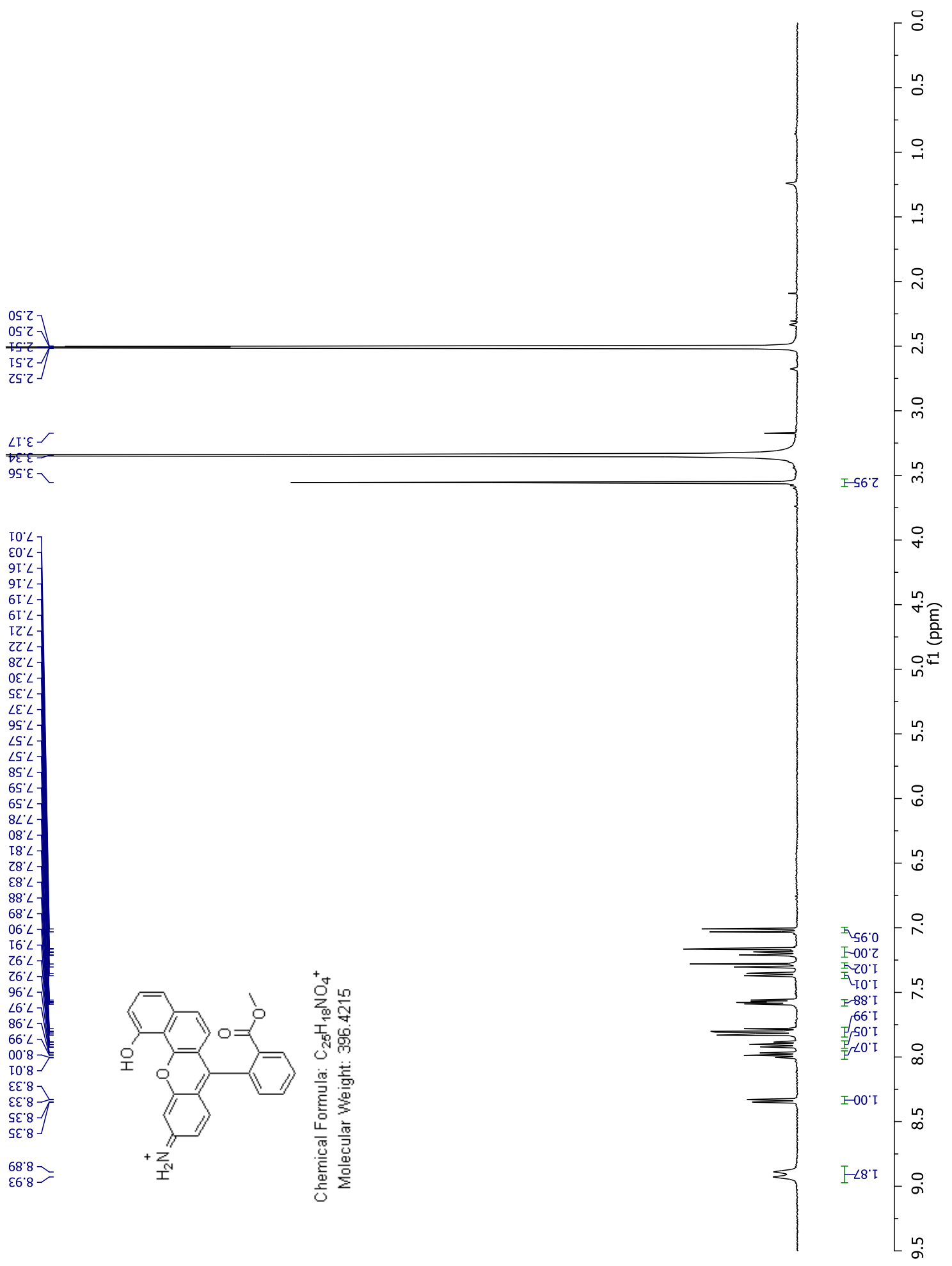

Figure A27 ${ }^{1} \mathrm{H}$ NMR spectrum of compound 3 


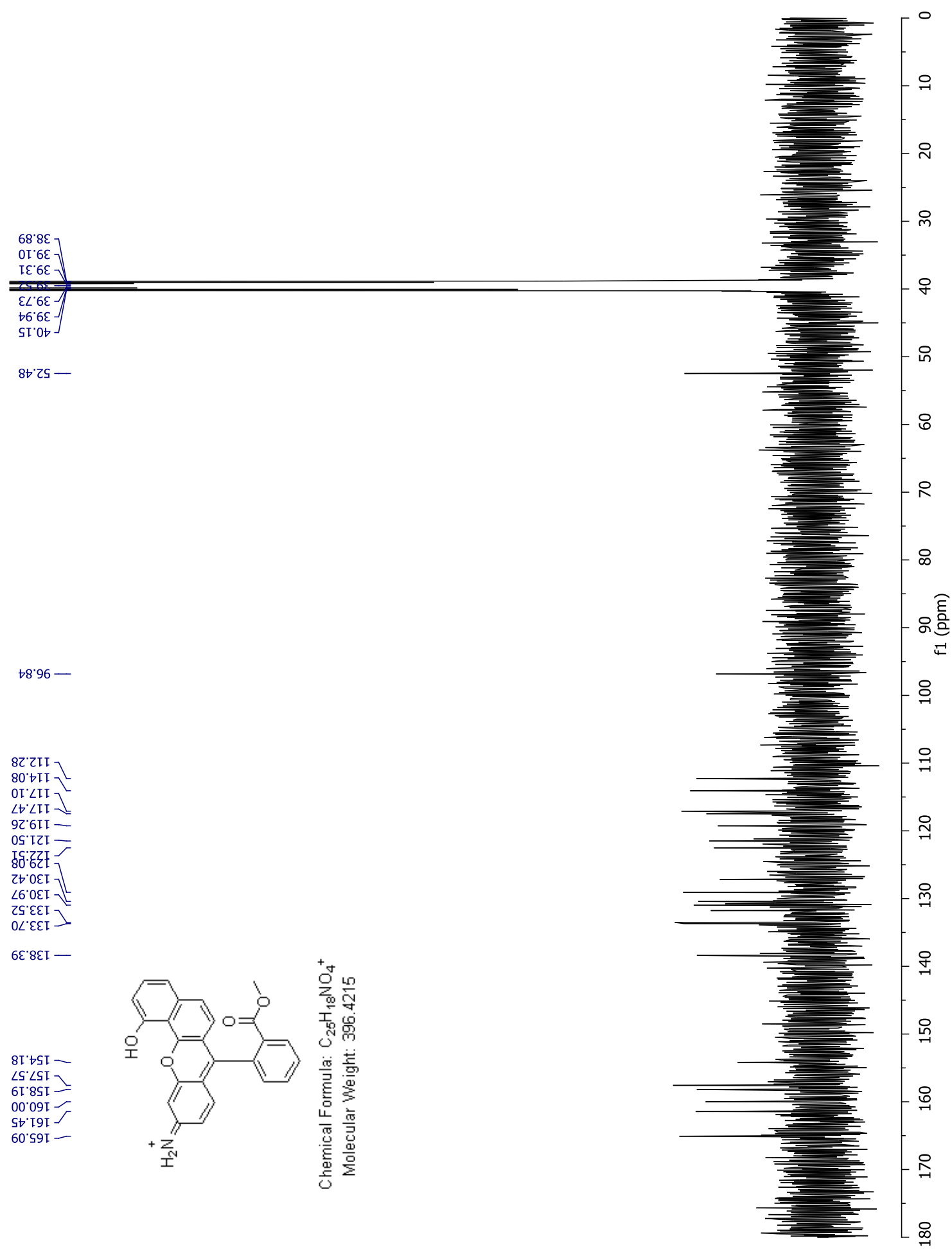

Figure A28 ${ }^{13} \mathrm{C}$ NMR spectrum of compound $\mathbf{3}$ 


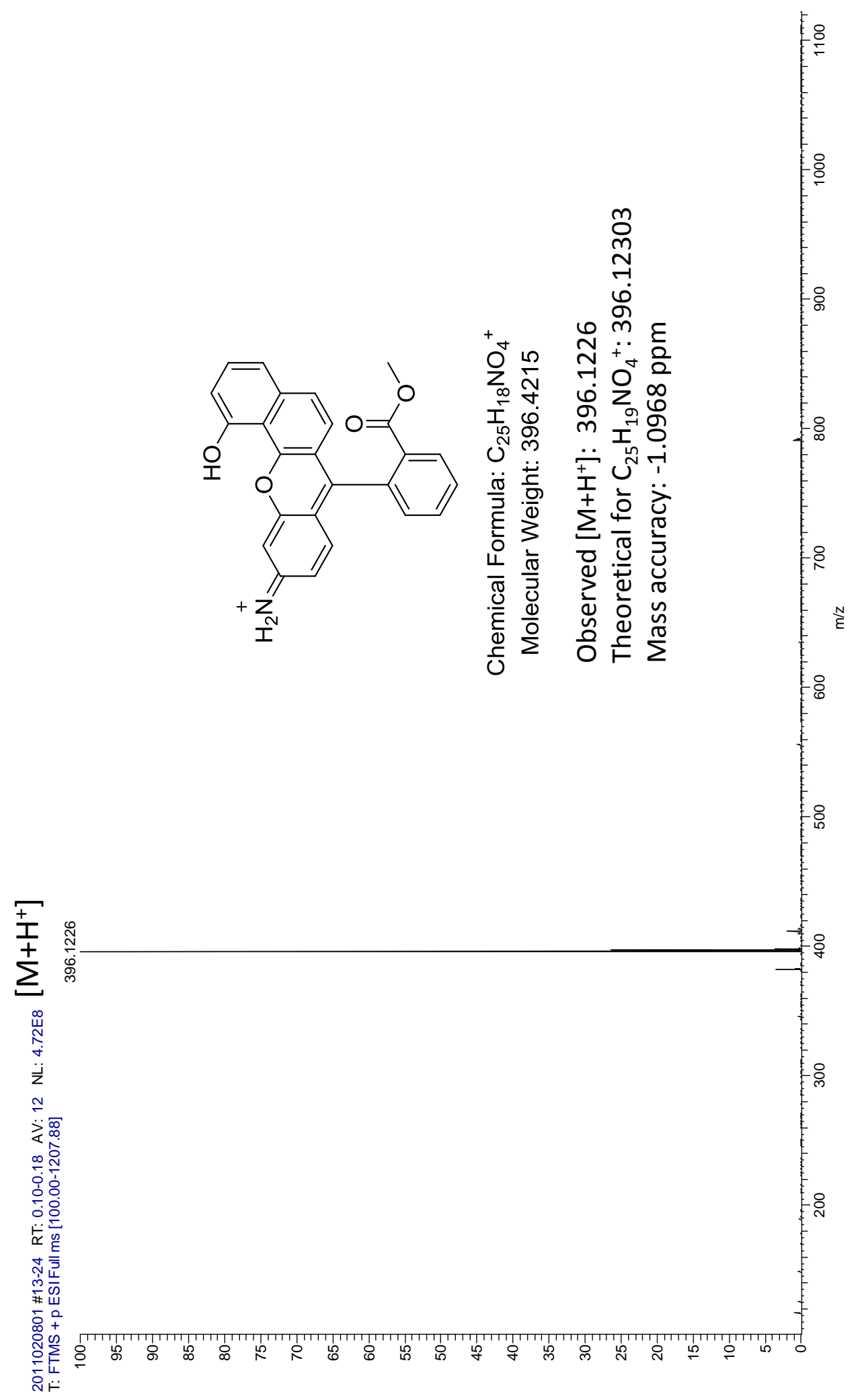

Figure A29 HR ESI positive mode spectrum of compound 3 


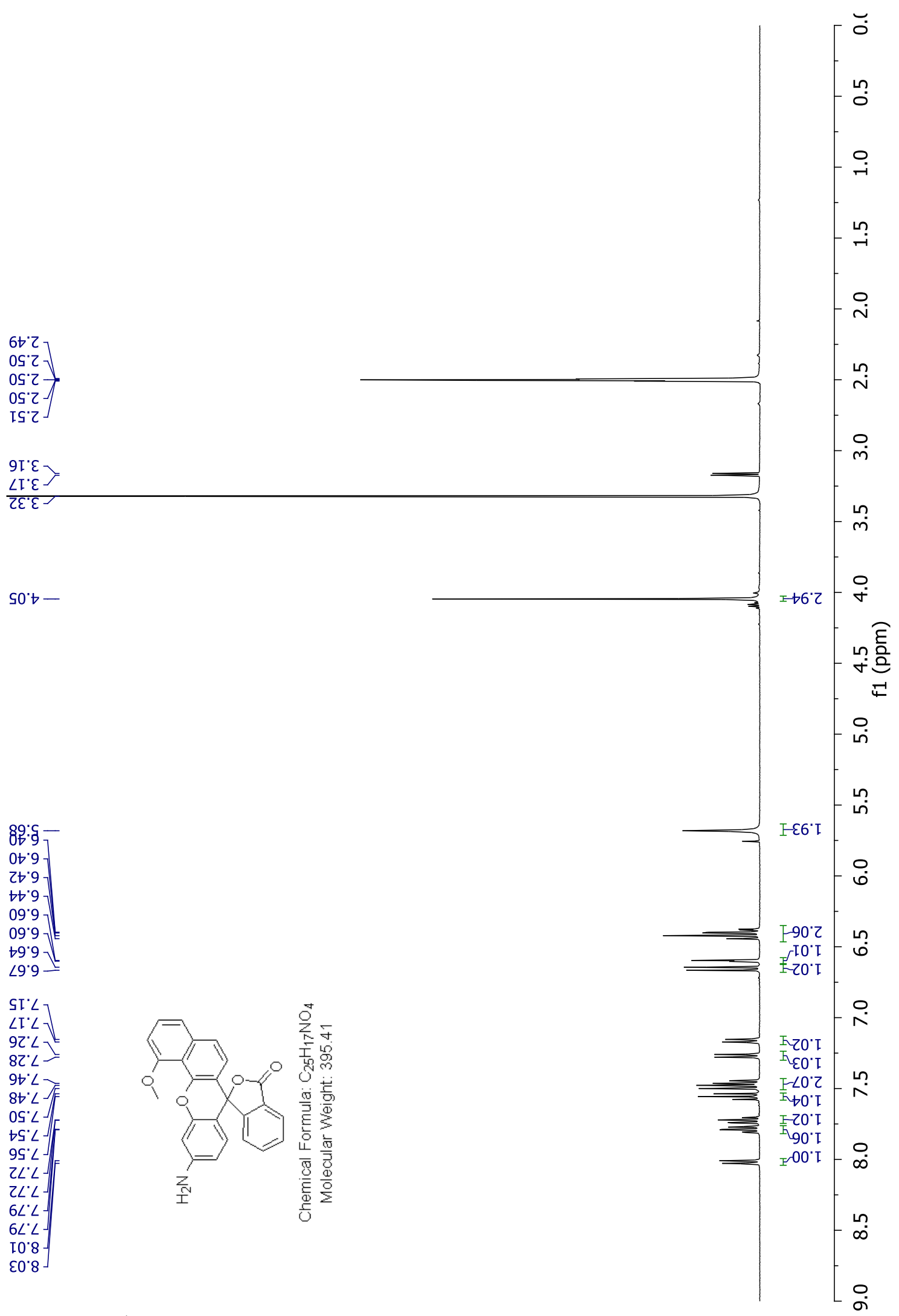

Figure A30 ${ }^{1} \mathrm{H}$ NMR spectrum of compound 33 


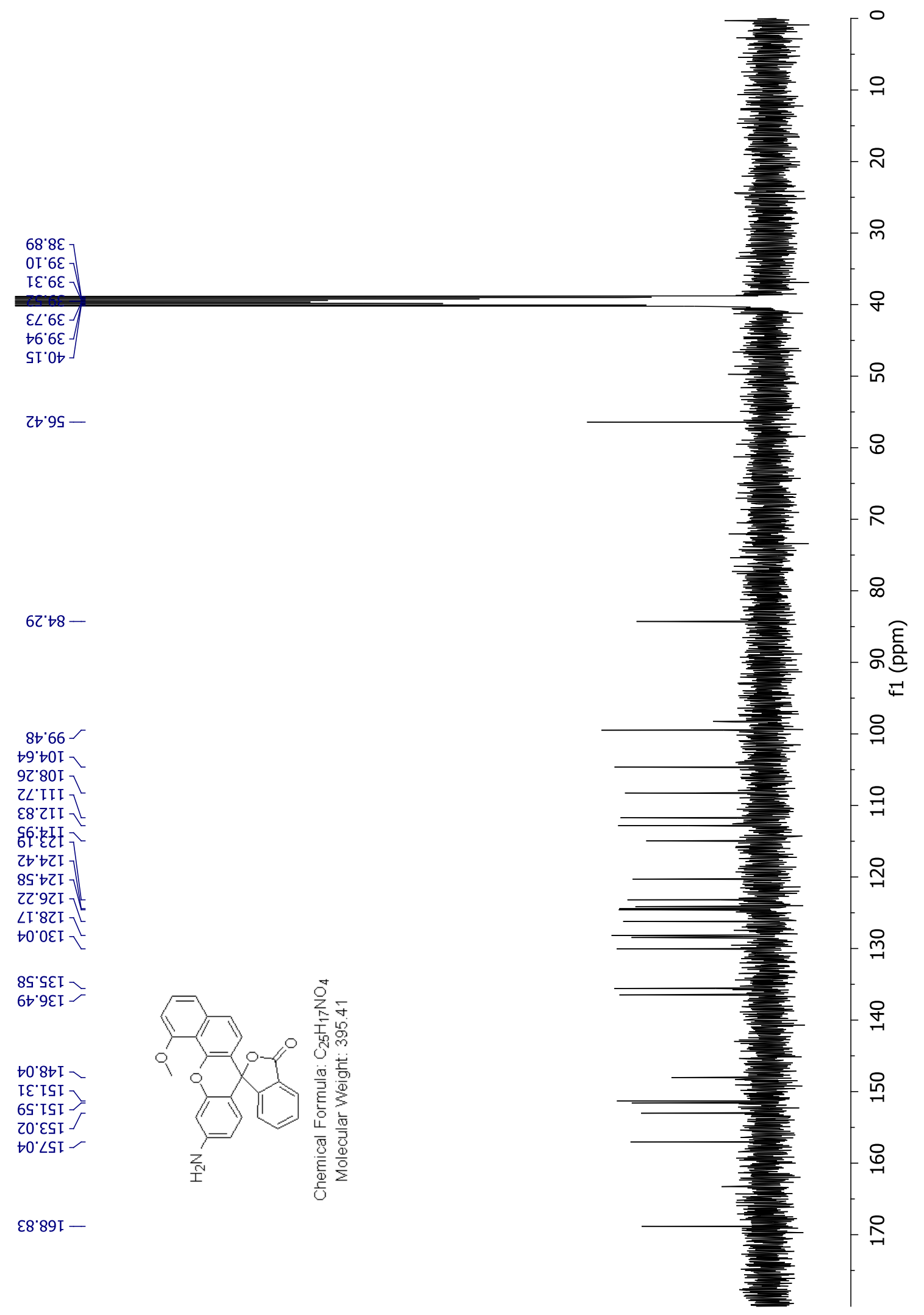

Figure A31 ${ }^{13} \mathrm{C}$ NMR spectrum of compound $\mathbf{3 3}$ 

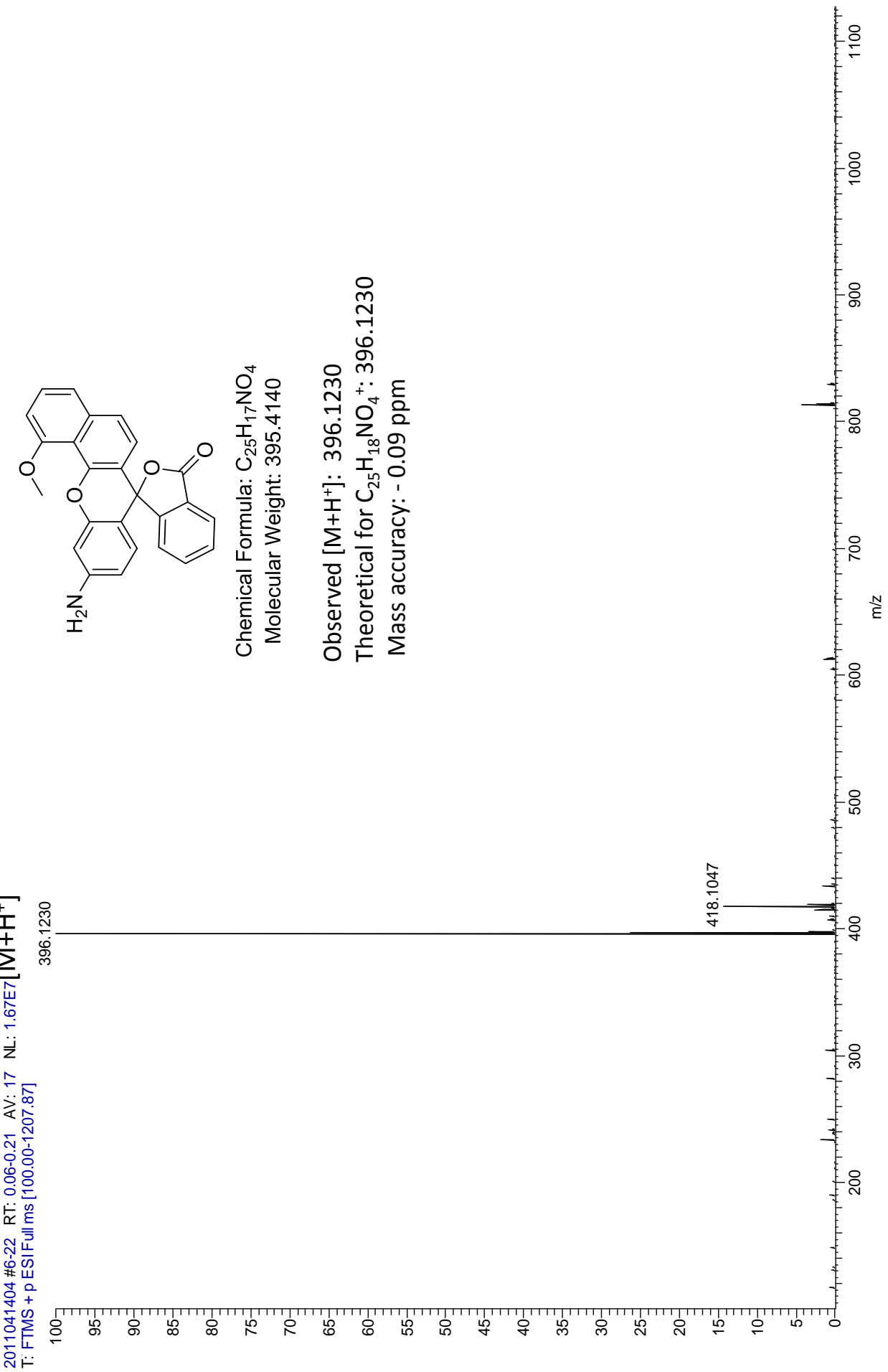

Figure A32 HR ESI positive mode spectrum of compound 33 


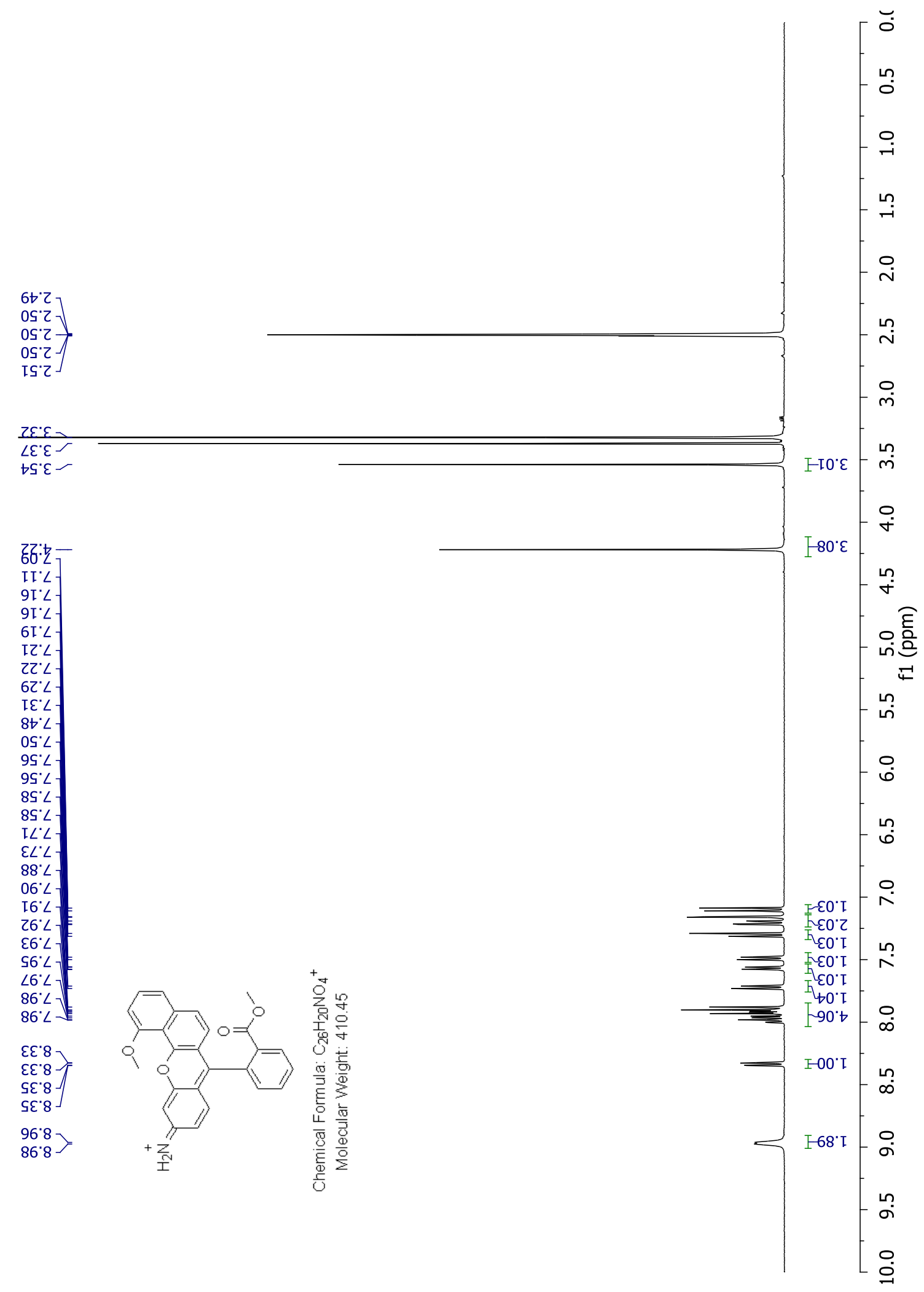

Figure A33 ${ }^{1} \mathrm{H}$ NMR spectrum of compound 4 


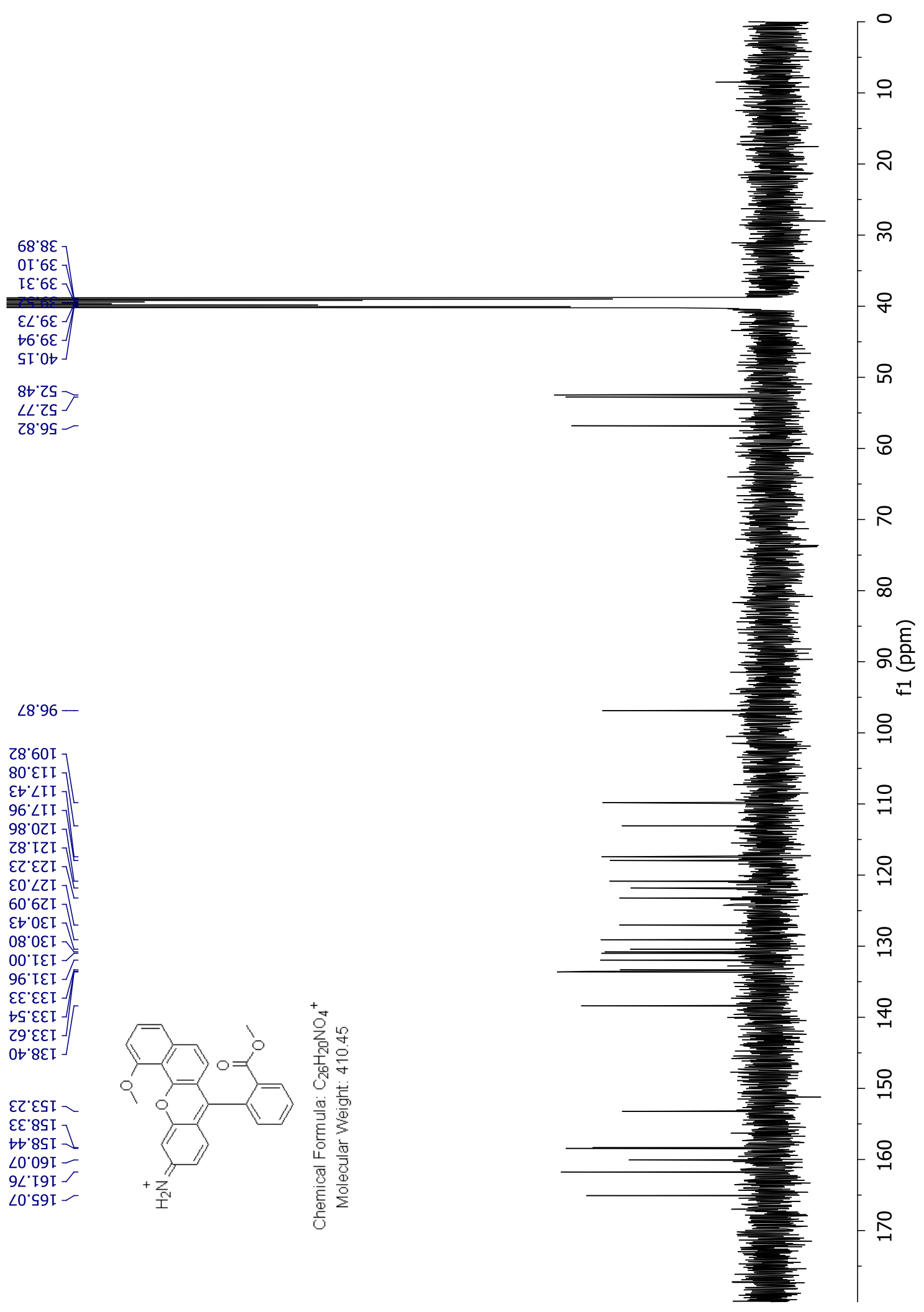

Figure A34 ${ }^{13} \mathrm{C}$ NMR spectrum of compound 4 


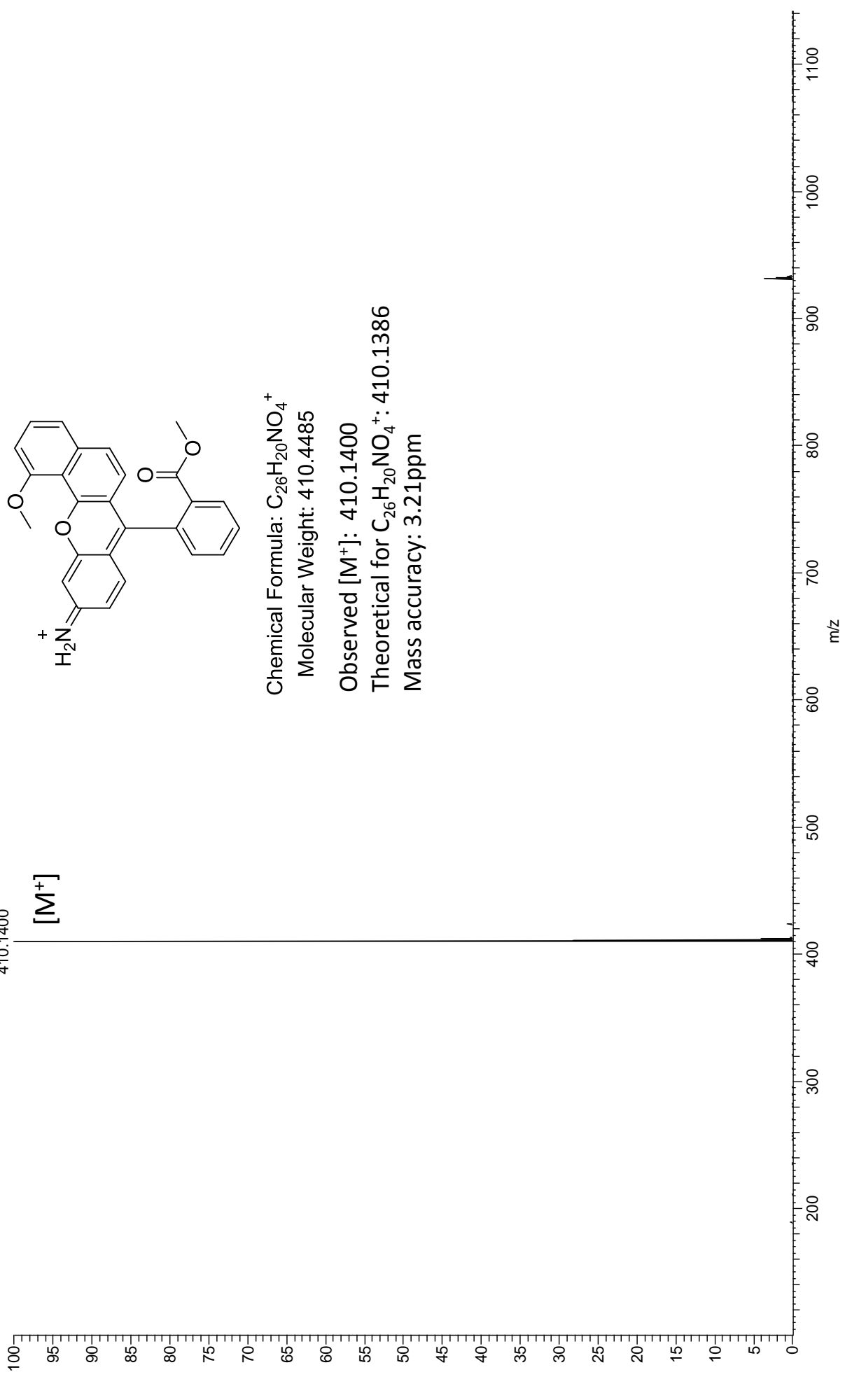

Figure A35 HR ESI positive mode spectrum of compound 4 


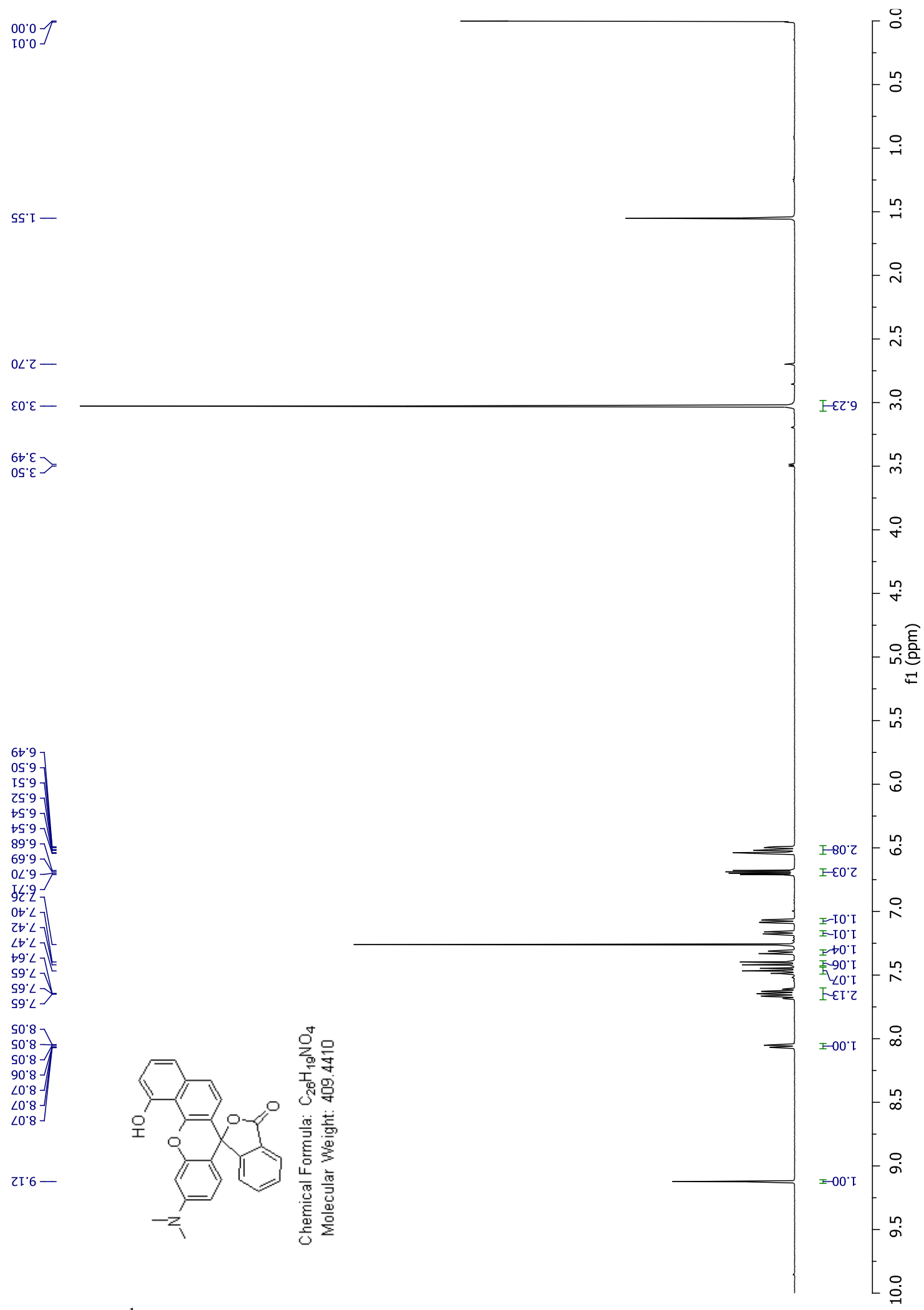

Figure A36 ${ }^{1} \mathrm{H}$ NMR spectrum of compound 34 


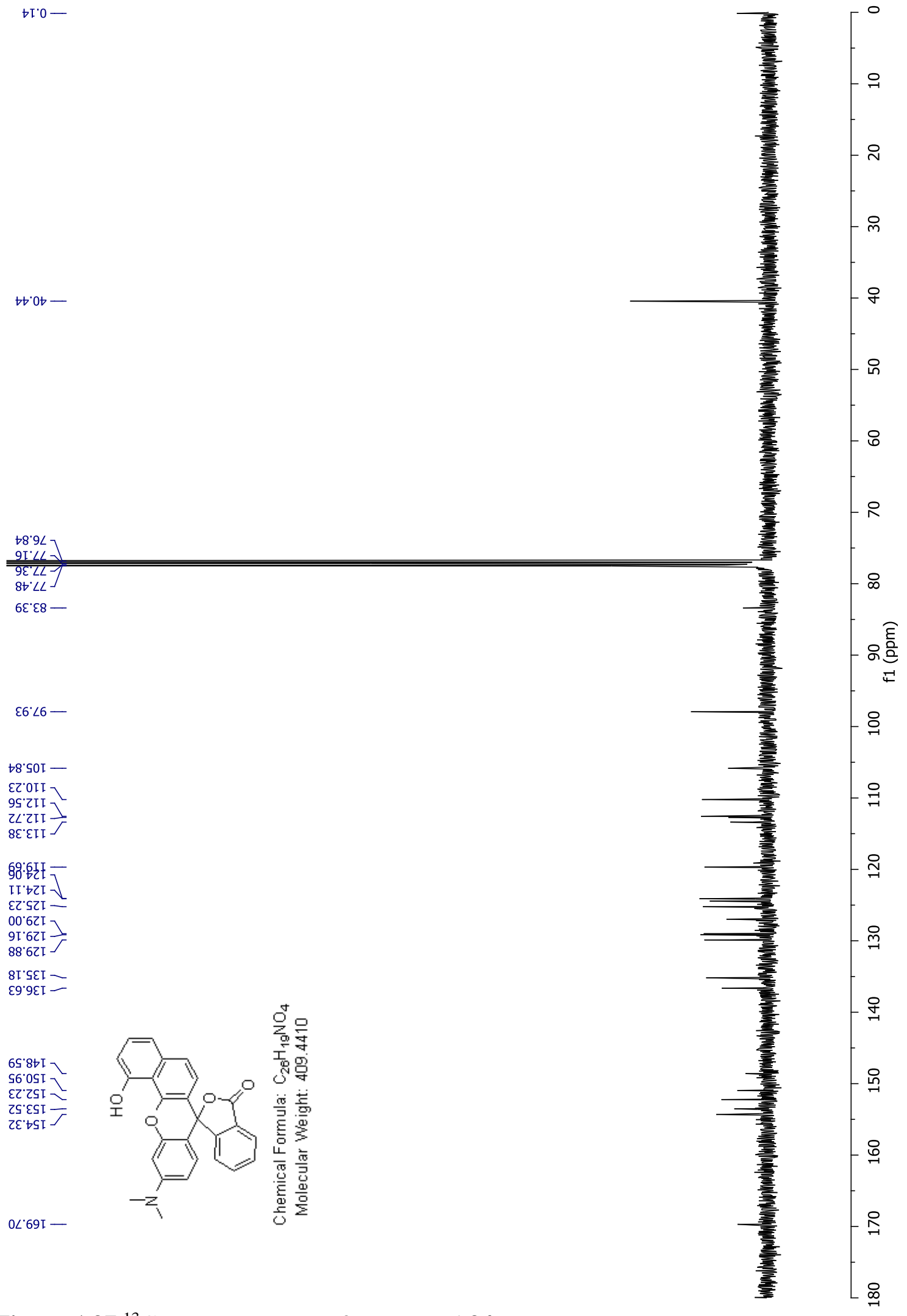

Figure A37 ${ }^{13} \mathrm{C}$ NMR spectrum of compound 34 


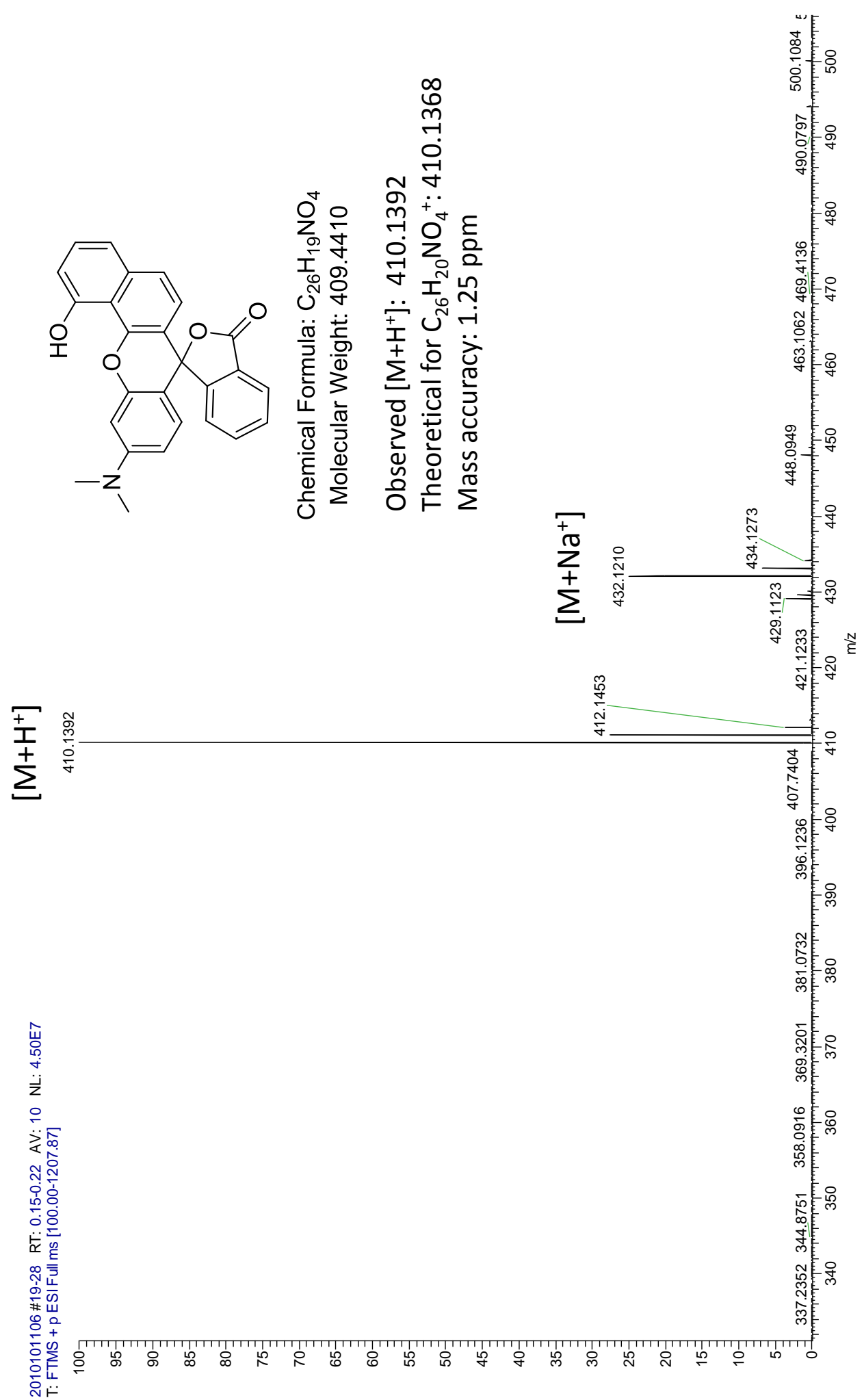

Figure A38 HR ESI positive mode spectrum of compound 34 


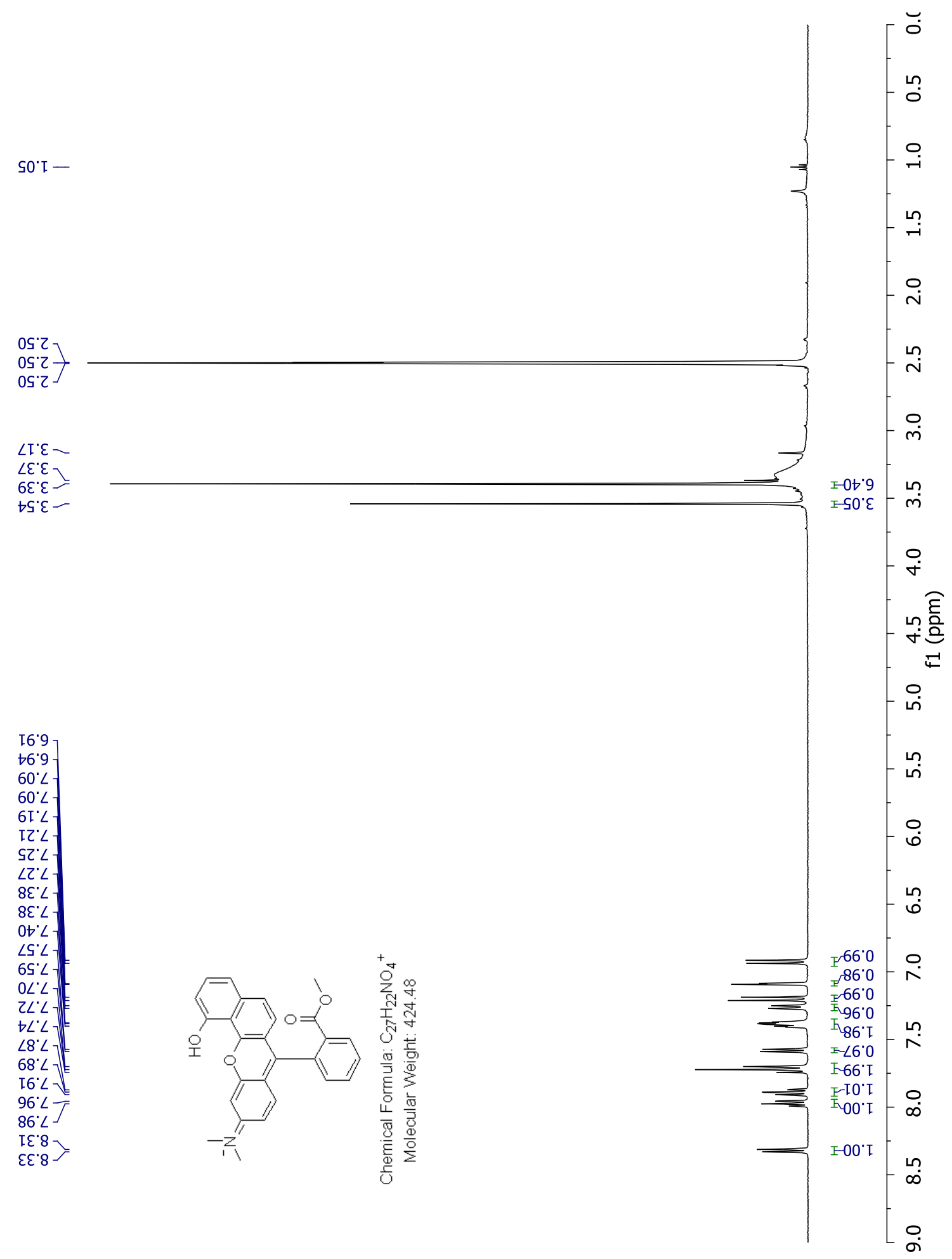

Figure A39 ${ }^{1} \mathrm{H}$ NMR spectrum of compound 5 


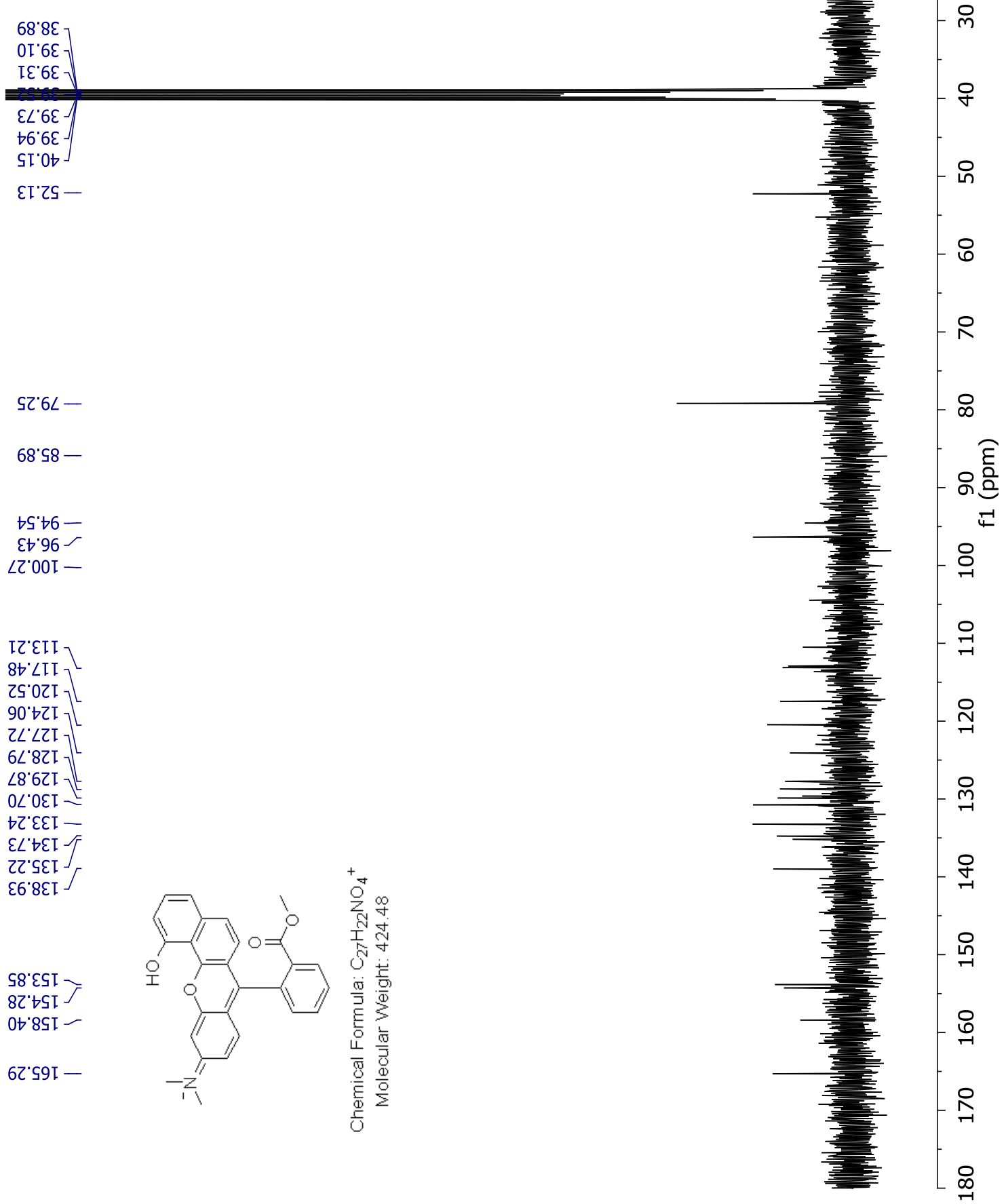

Figure A40 ${ }^{13} \mathrm{C}$ NMR spectrum of compound 5 


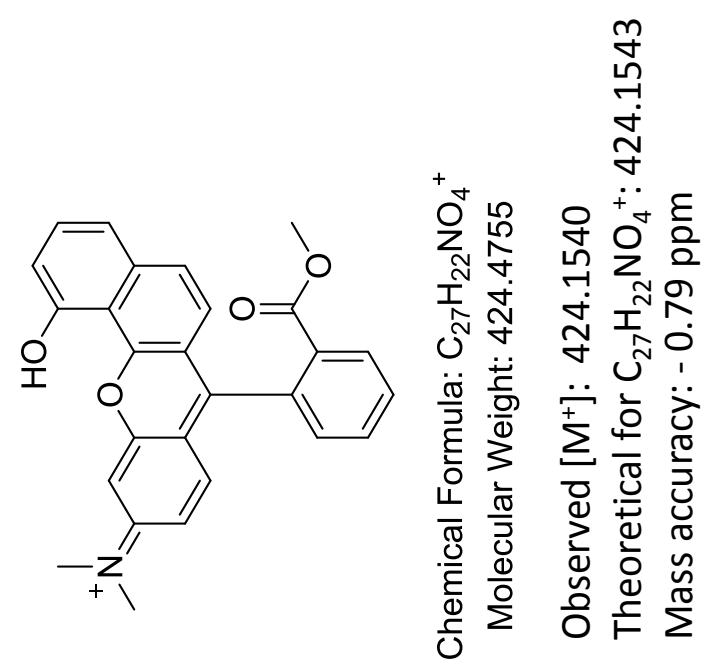

蛋

พ

Figure A41 HR ESI positive mode spectrum of compound 5 


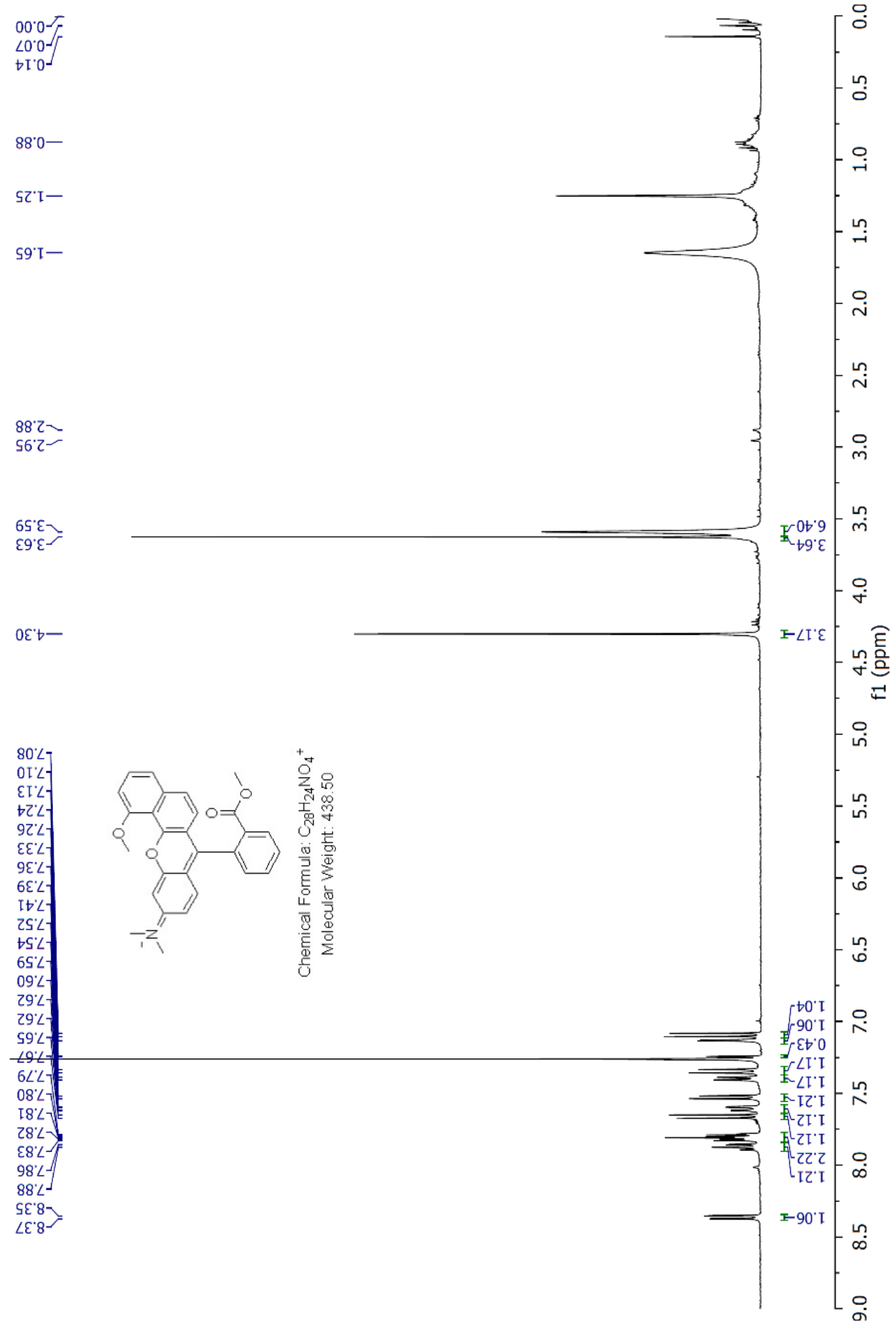

Figure A42 ${ }^{1} \mathrm{H}$ NMR spectrum of compound 6 
เ8.62-

$\varepsilon \varsigma^{\prime}$ Zь-

$9 L ' Z S-$

II' $\angle S-$

$8 L^{\prime} 96-$
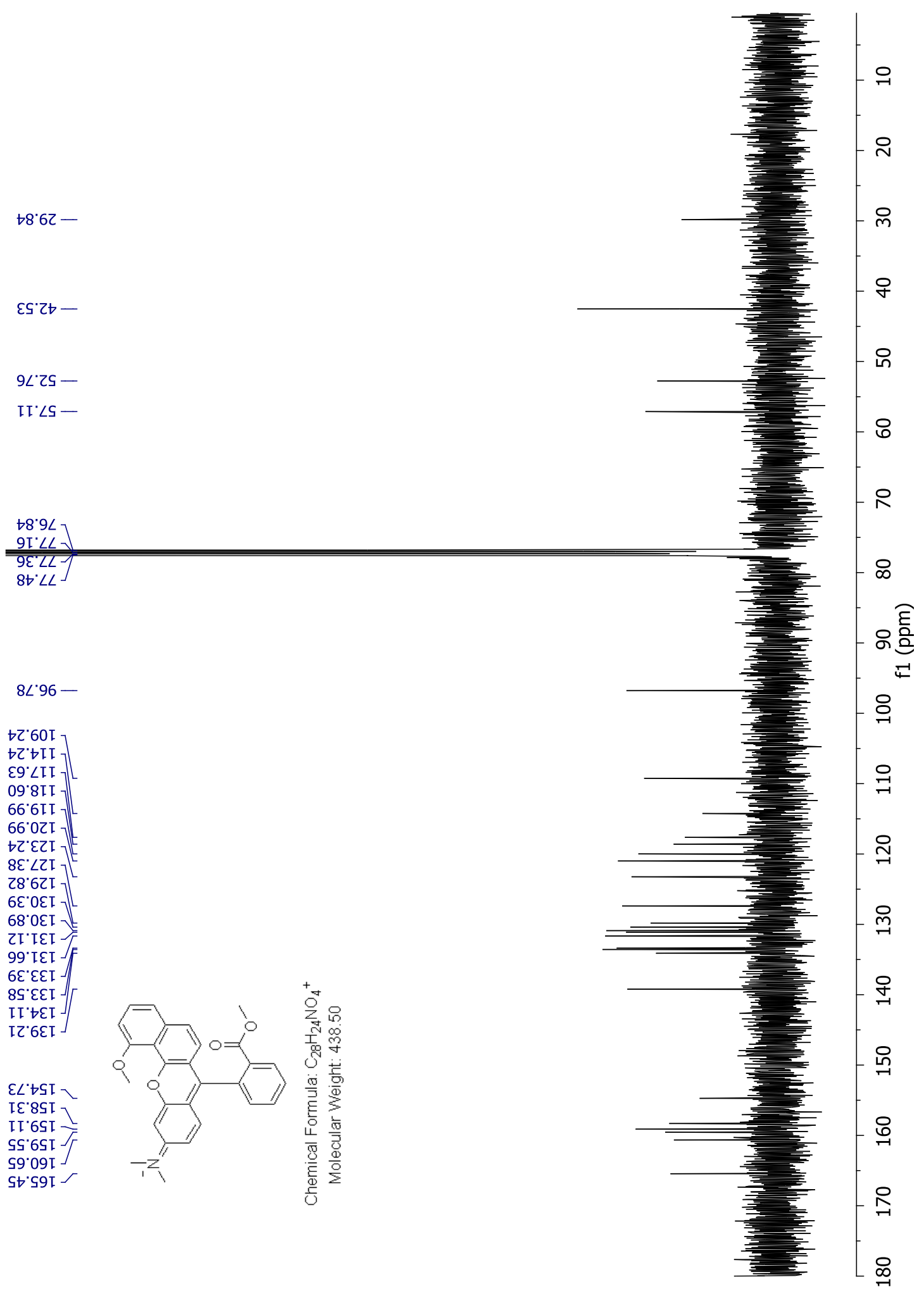

Figure A43 ${ }^{1} \mathrm{H}$ NMR spectrum of compound 6 


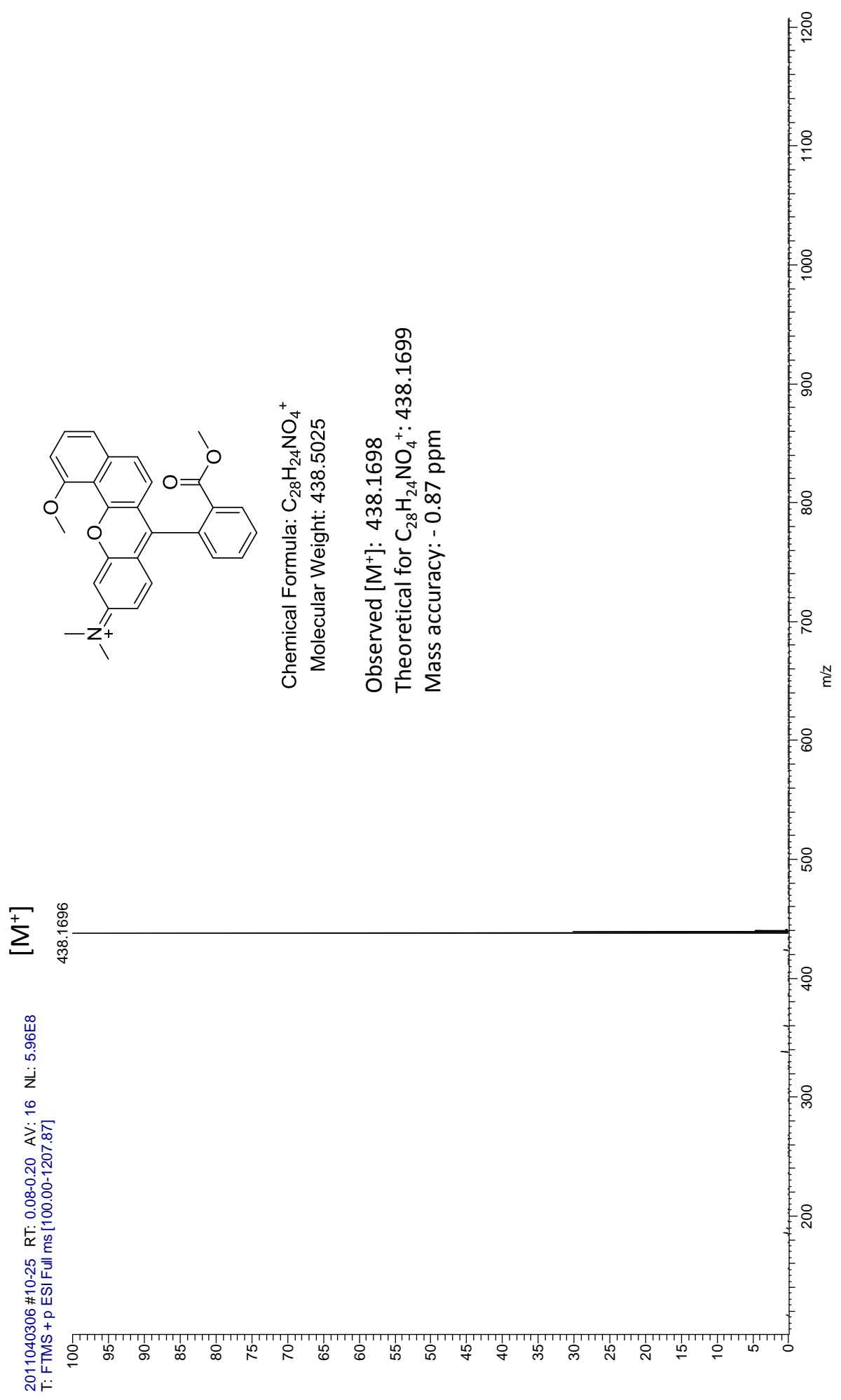

Figure A44 HR ESI positive mode spectrum of compound 6 

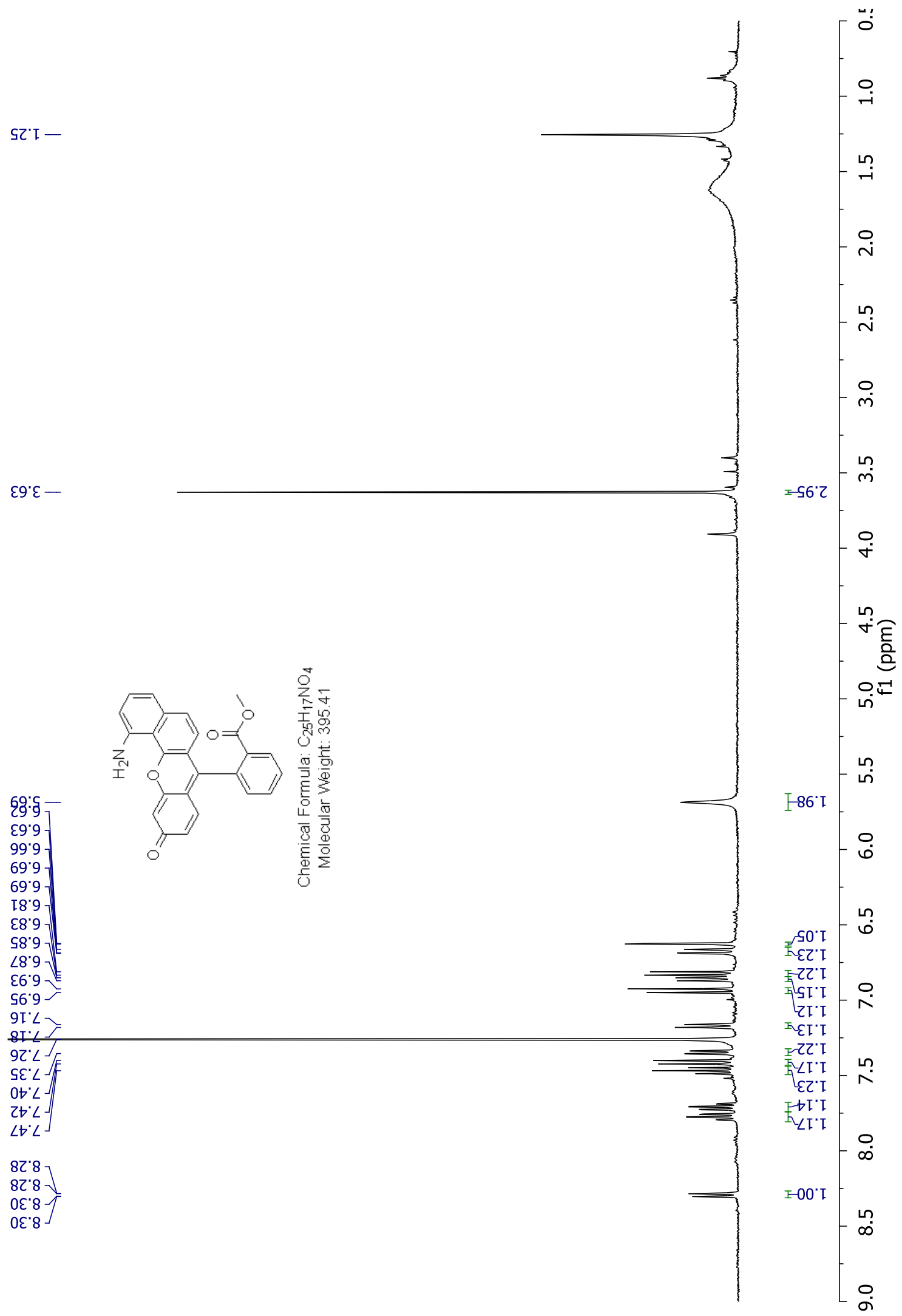

Figure A45 ${ }^{1} \mathrm{H}$ NMR spectrum of compound 7 


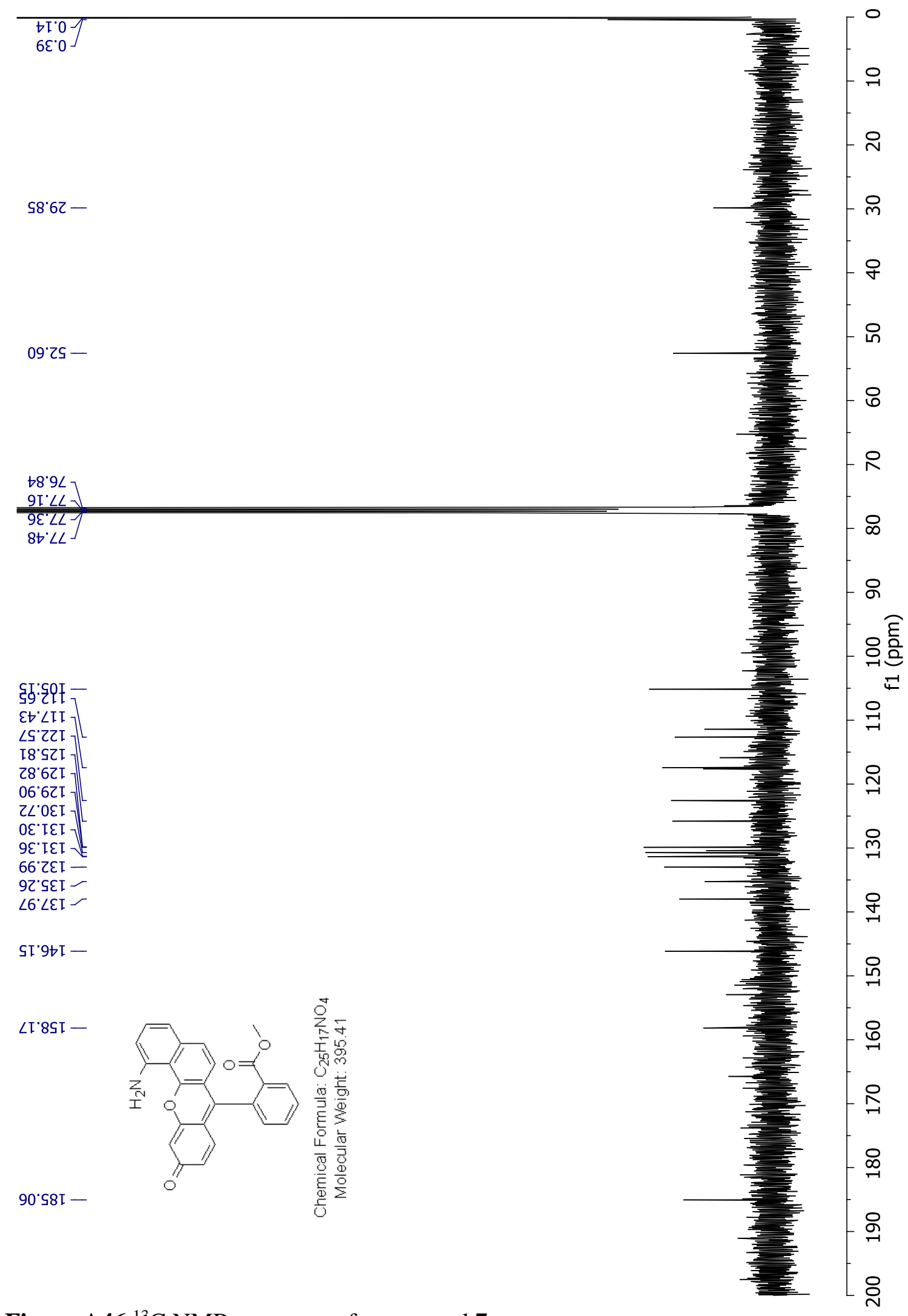

Figure $\mathbf{A 4 6}{ }^{13} \mathrm{C}$ NMR spectrum of compound 7 

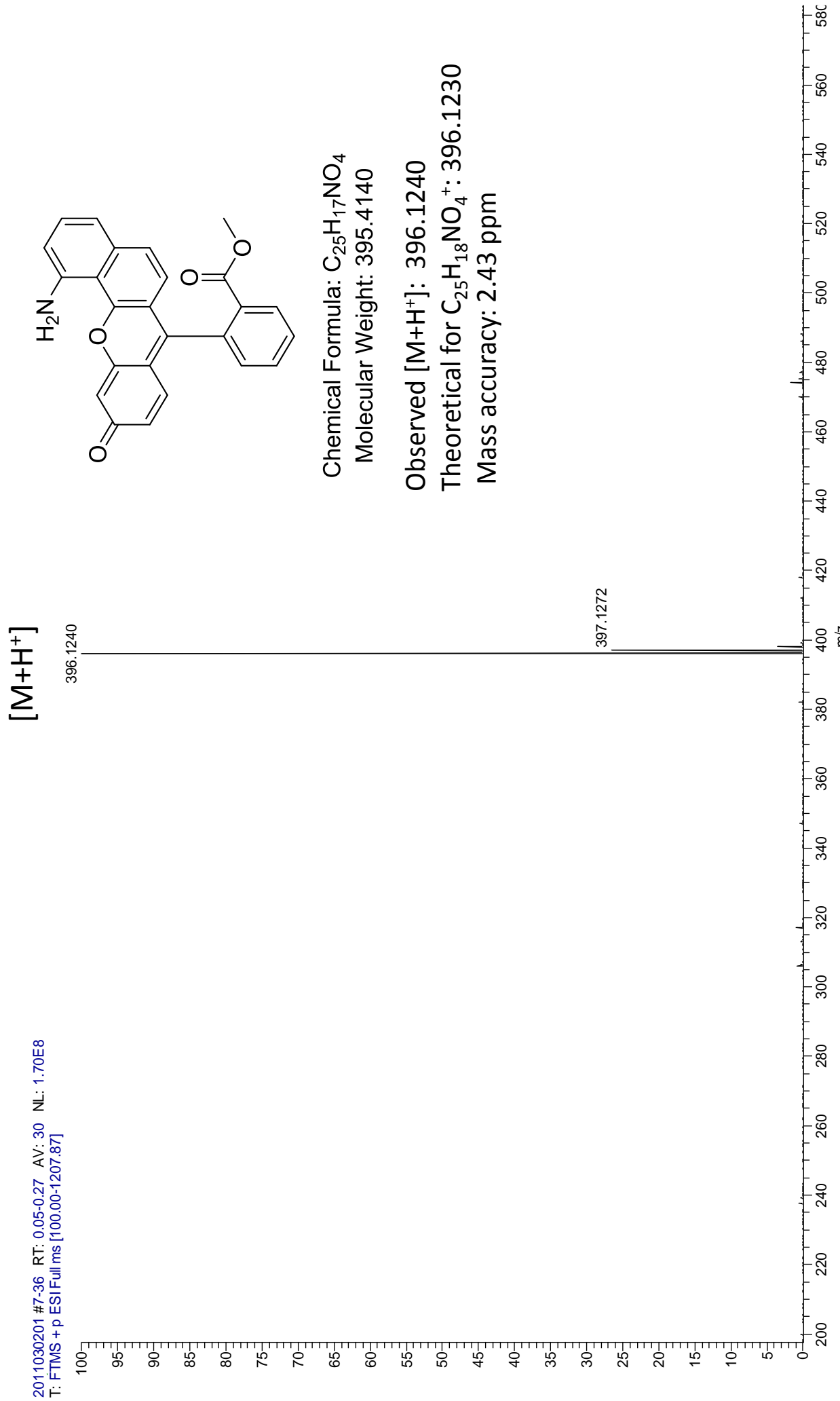

Figure A47 HR ESI positive mode spectrum of compound 7 

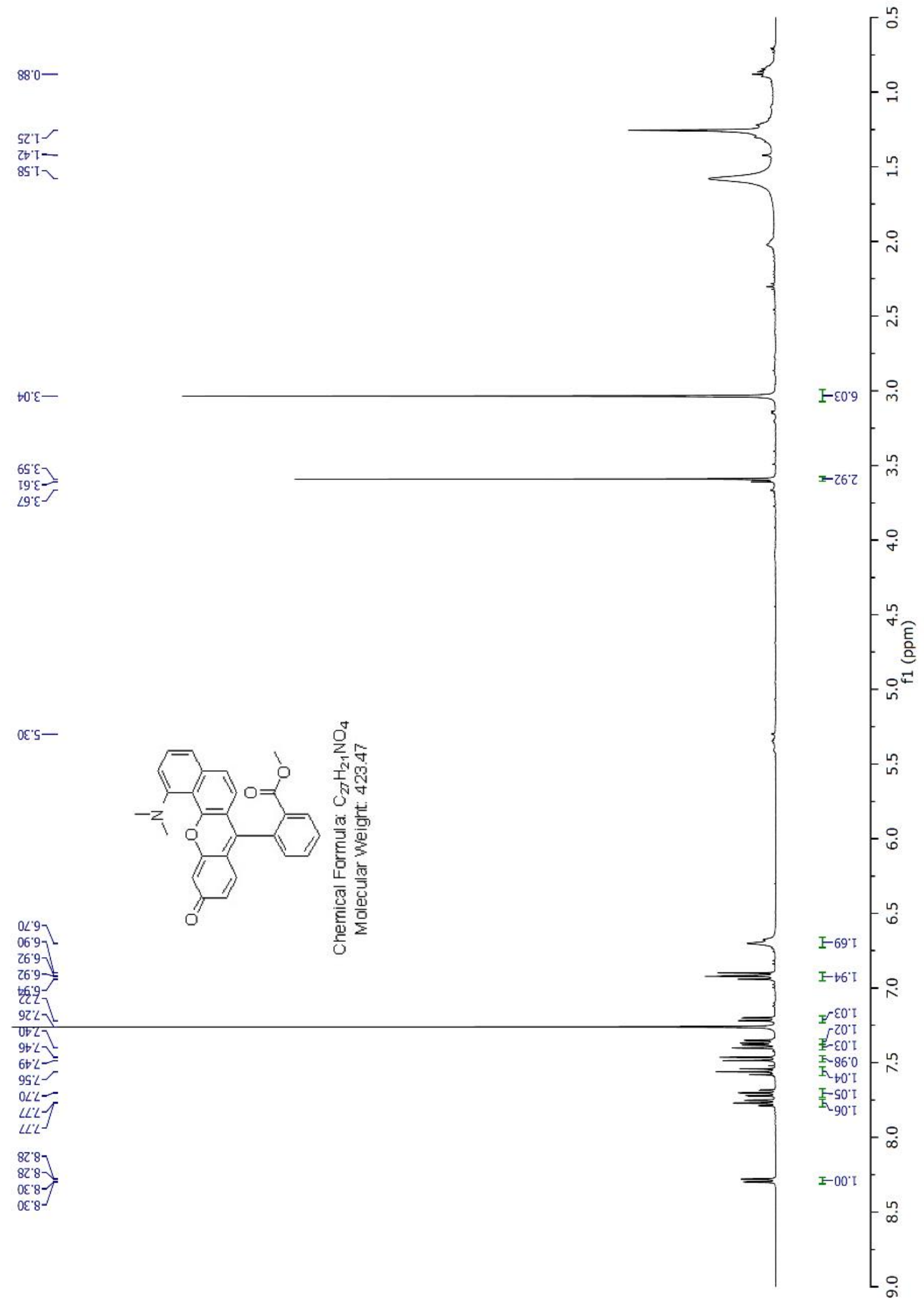

Figure A48 ${ }^{1} \mathrm{H}$ NMR spectrum of compound 8 


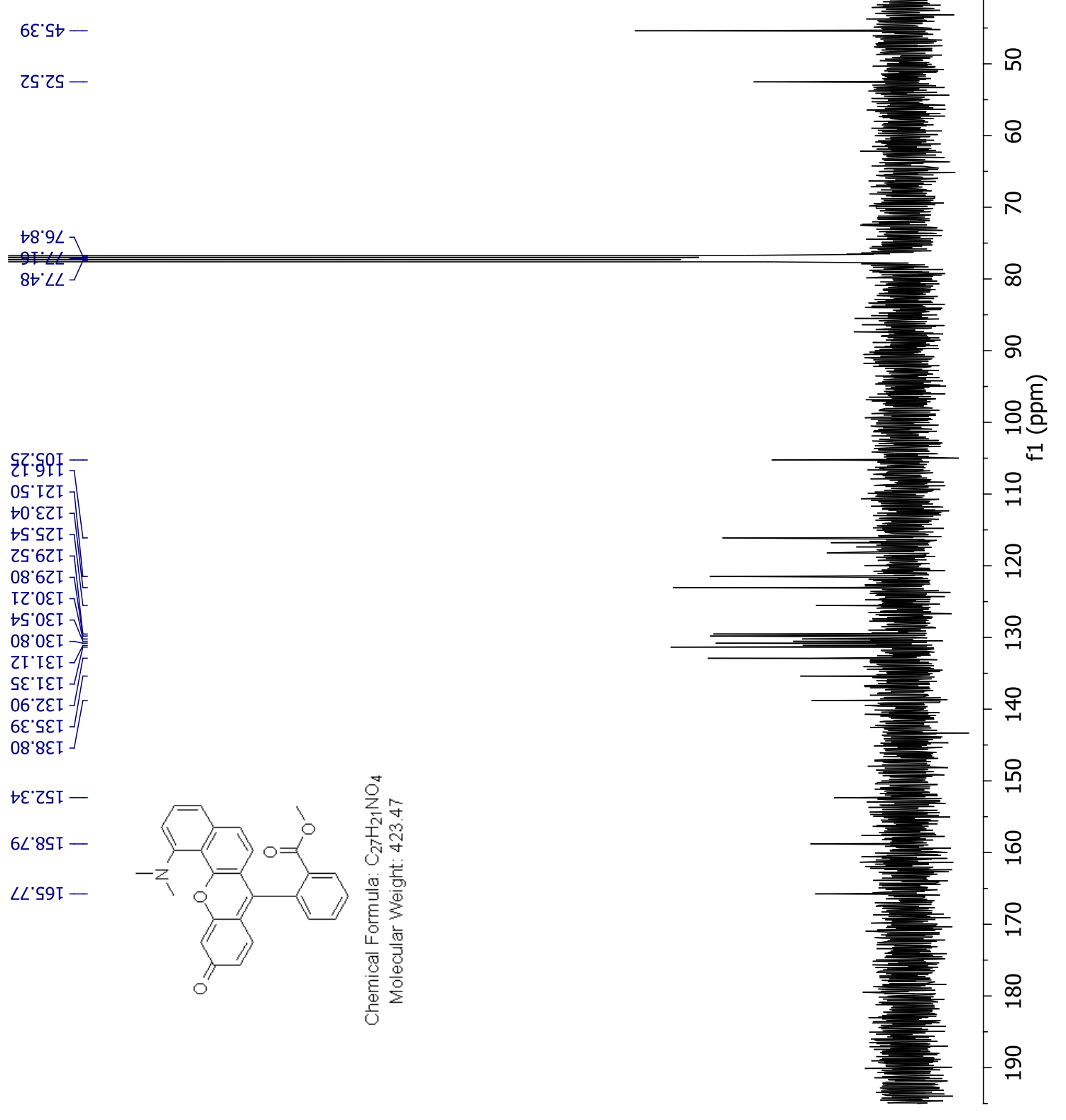

Figure A49 ${ }^{13} \mathrm{C}$ NMR spectrum of compound 8 


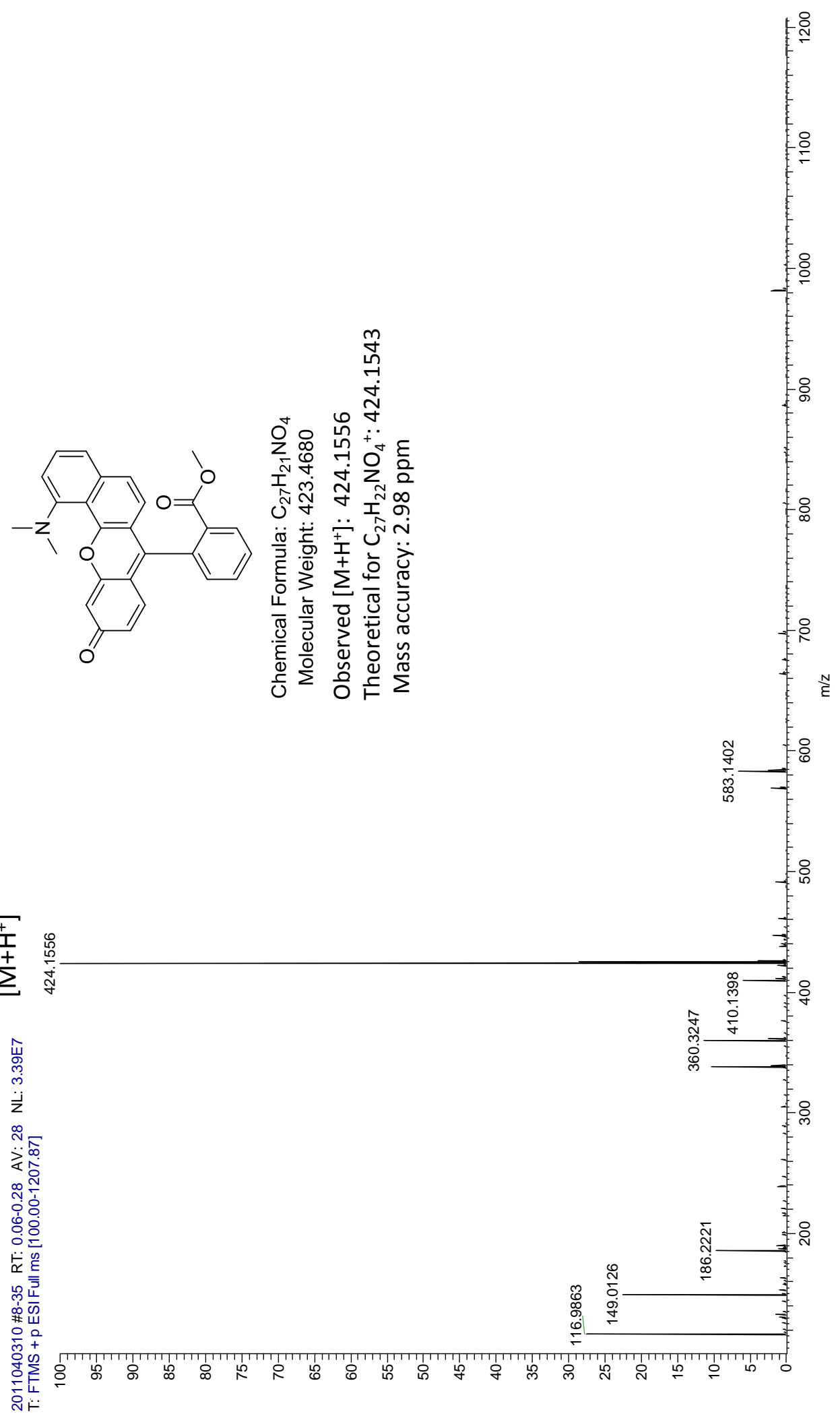

Figure A50 HR ESI positive mode spectrum of compound $\mathbf{8}$ 


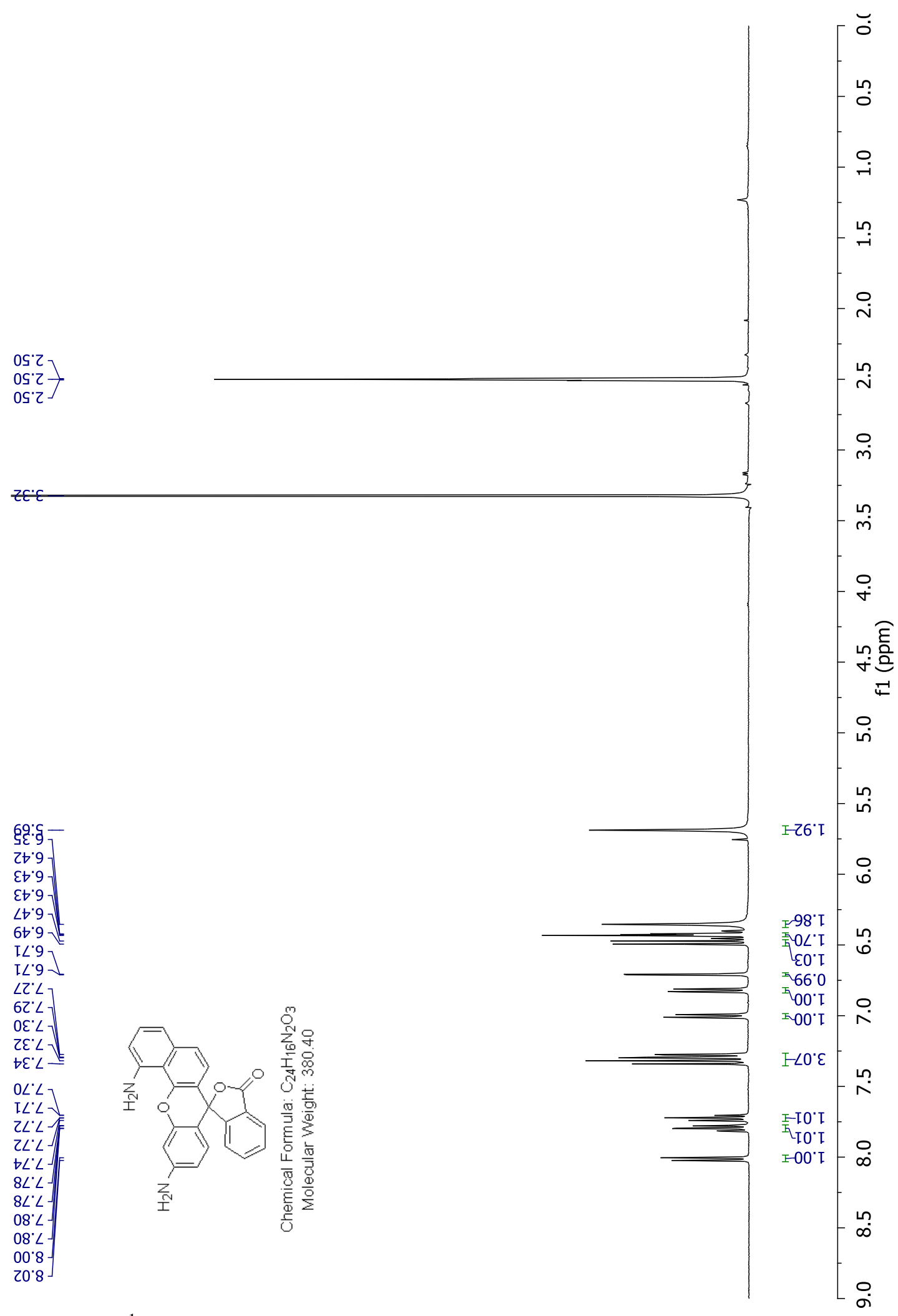

Figure A51 ${ }^{1} \mathrm{H}$ NMR spectrum of compound 37 


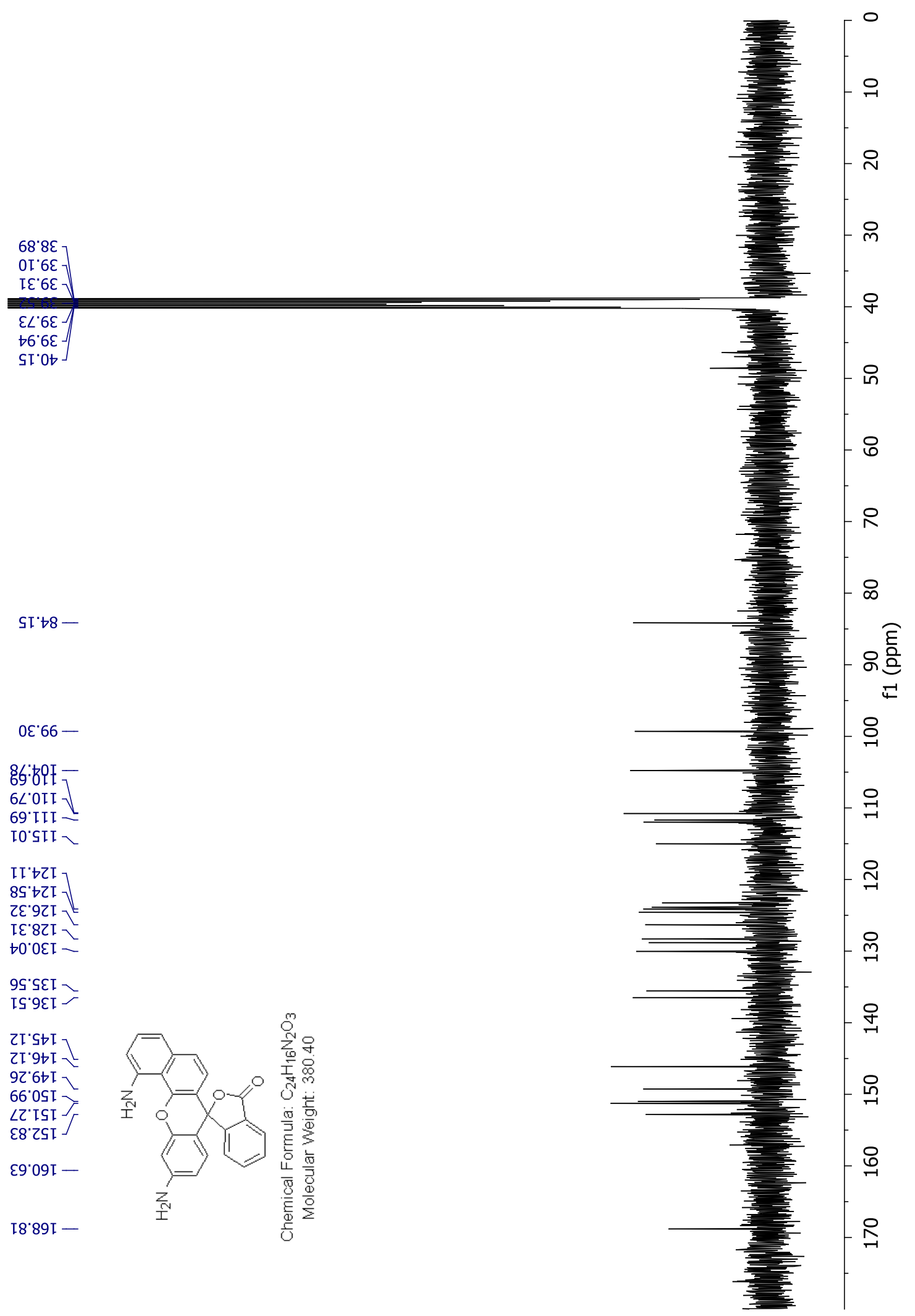

Figure A52 ${ }^{13} \mathrm{C}$ NMR spectrum of compound 37 

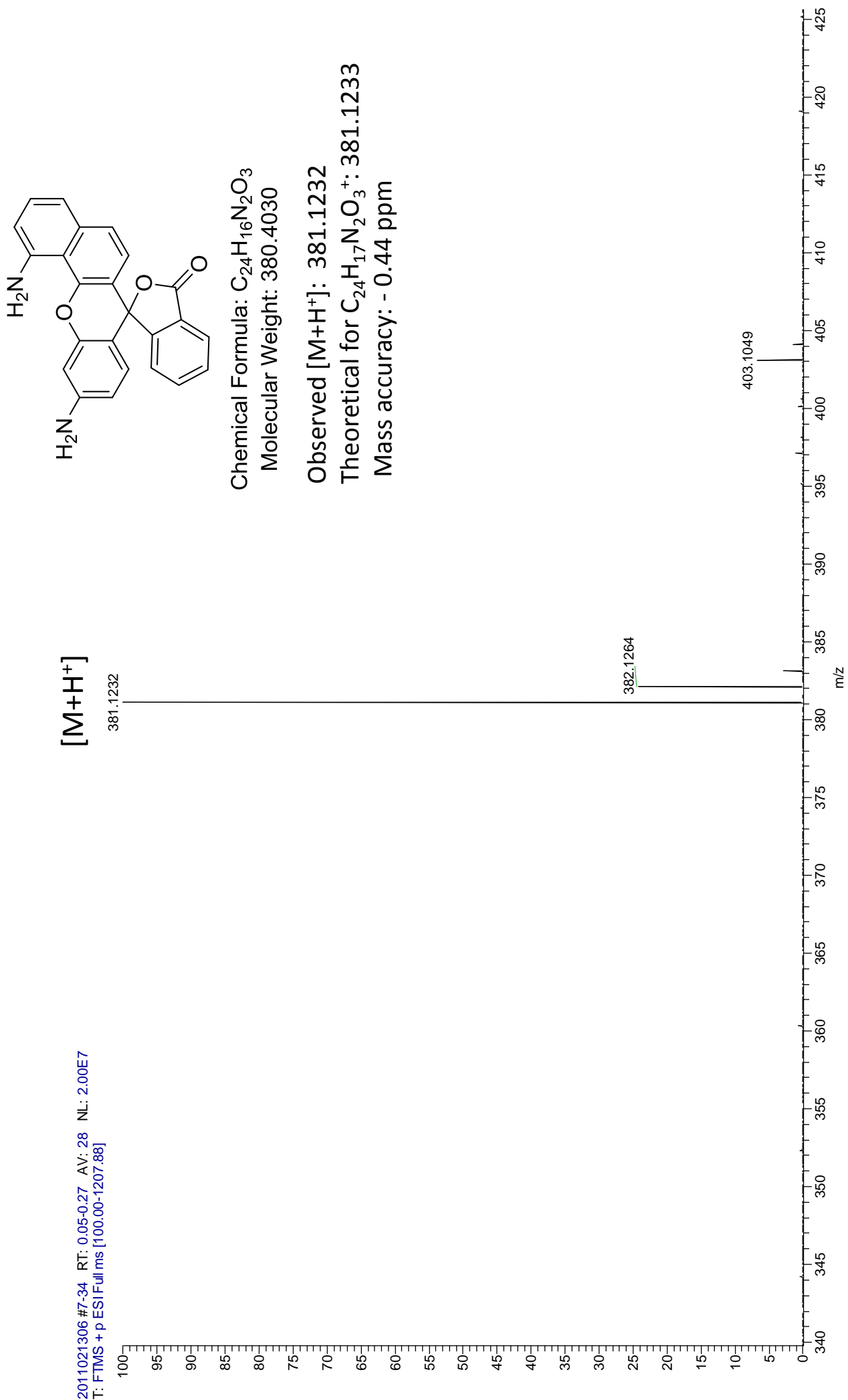

Figure A53 HR ESI positive mode spectrum of compound 37 


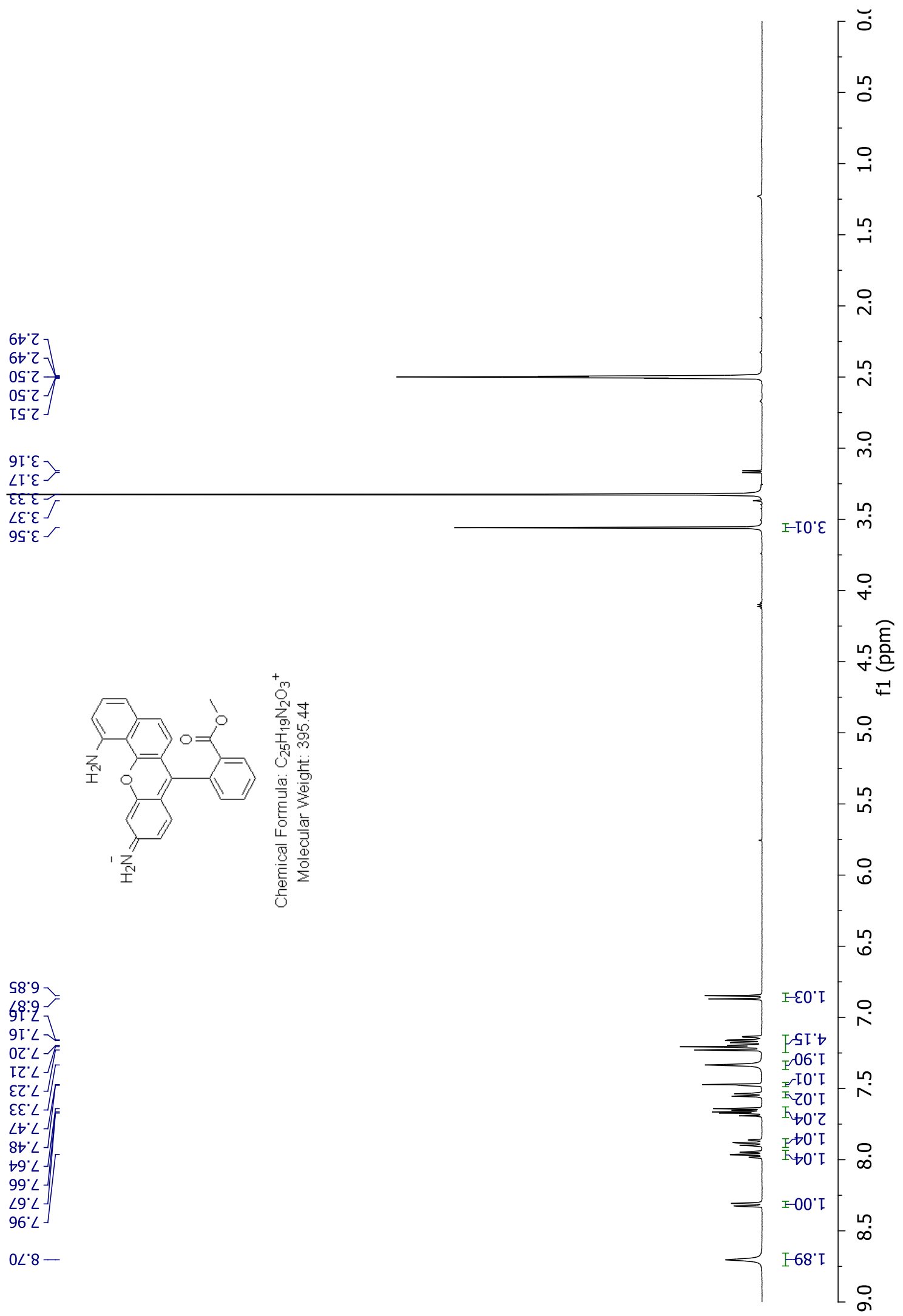

Figure A54 ${ }^{1} \mathrm{H}$ NMR spectrum of compound 9 


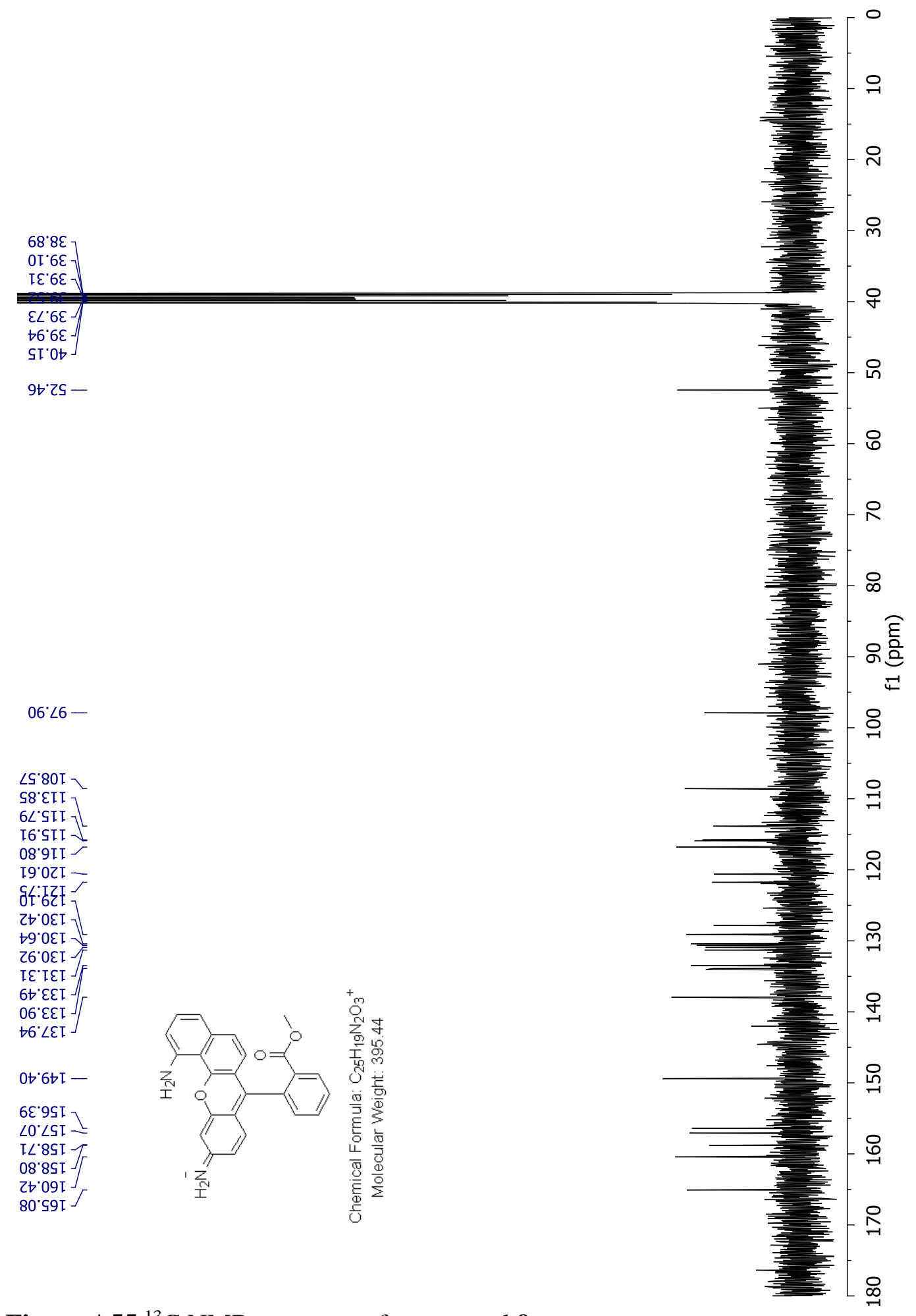

Figure $\mathbf{A 5 5}{ }^{13} \mathrm{C}$ NMR spectrum of compound 9 


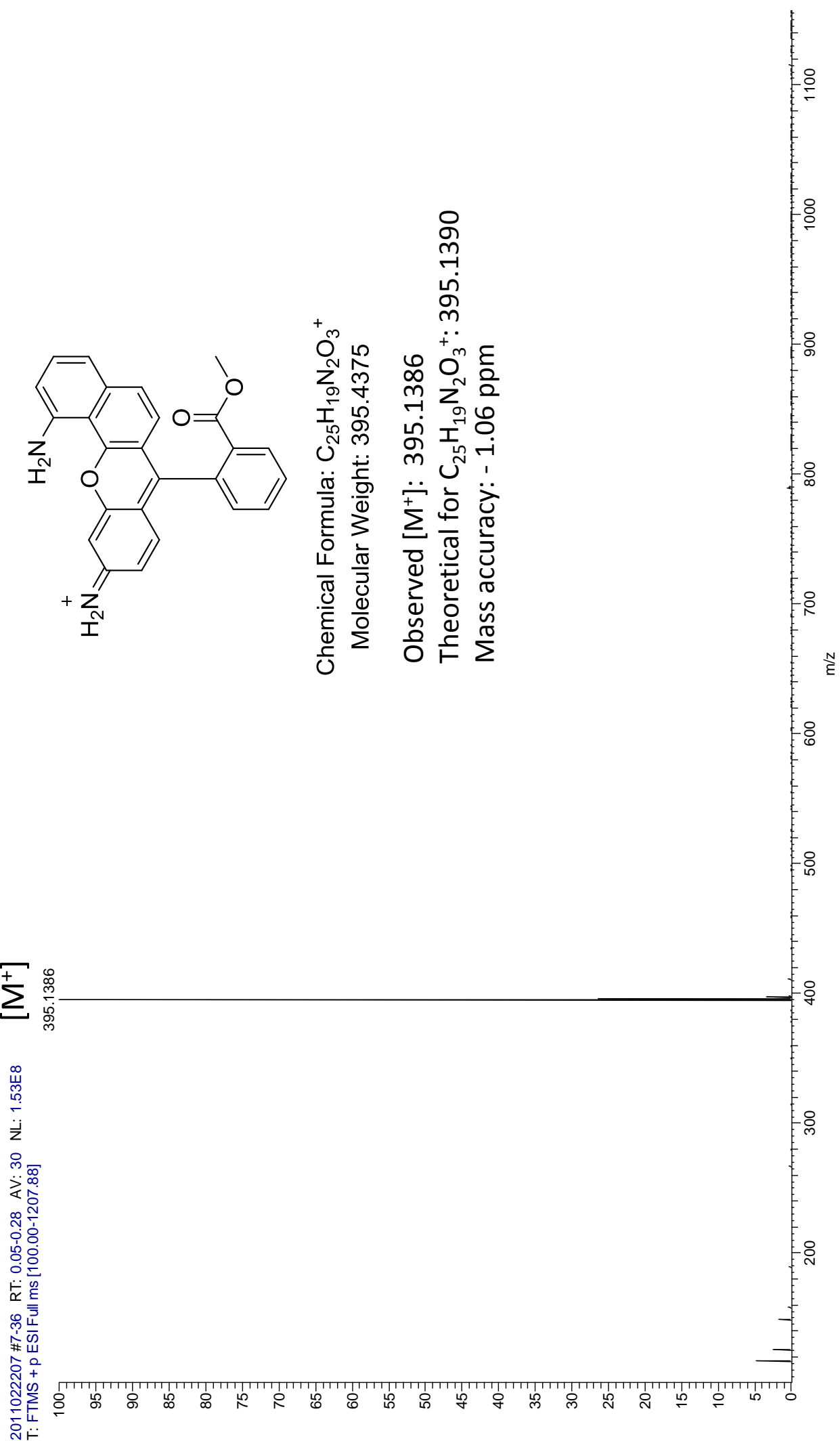

Figure A56 HR ESI positive mode spectrum of compound 9 


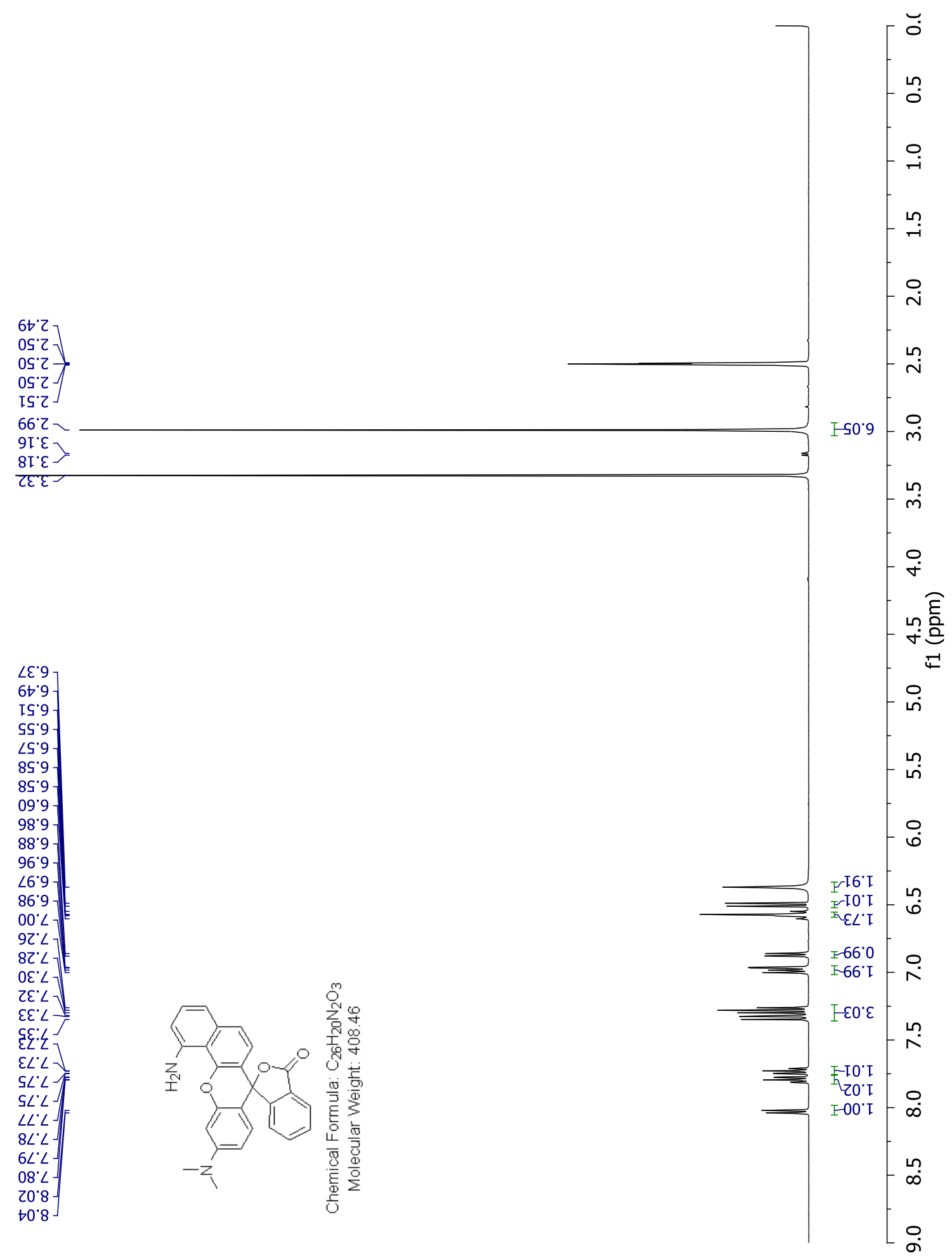

Figure A57 ${ }^{1} \mathrm{H}$ NMR spectrum of compound 38 


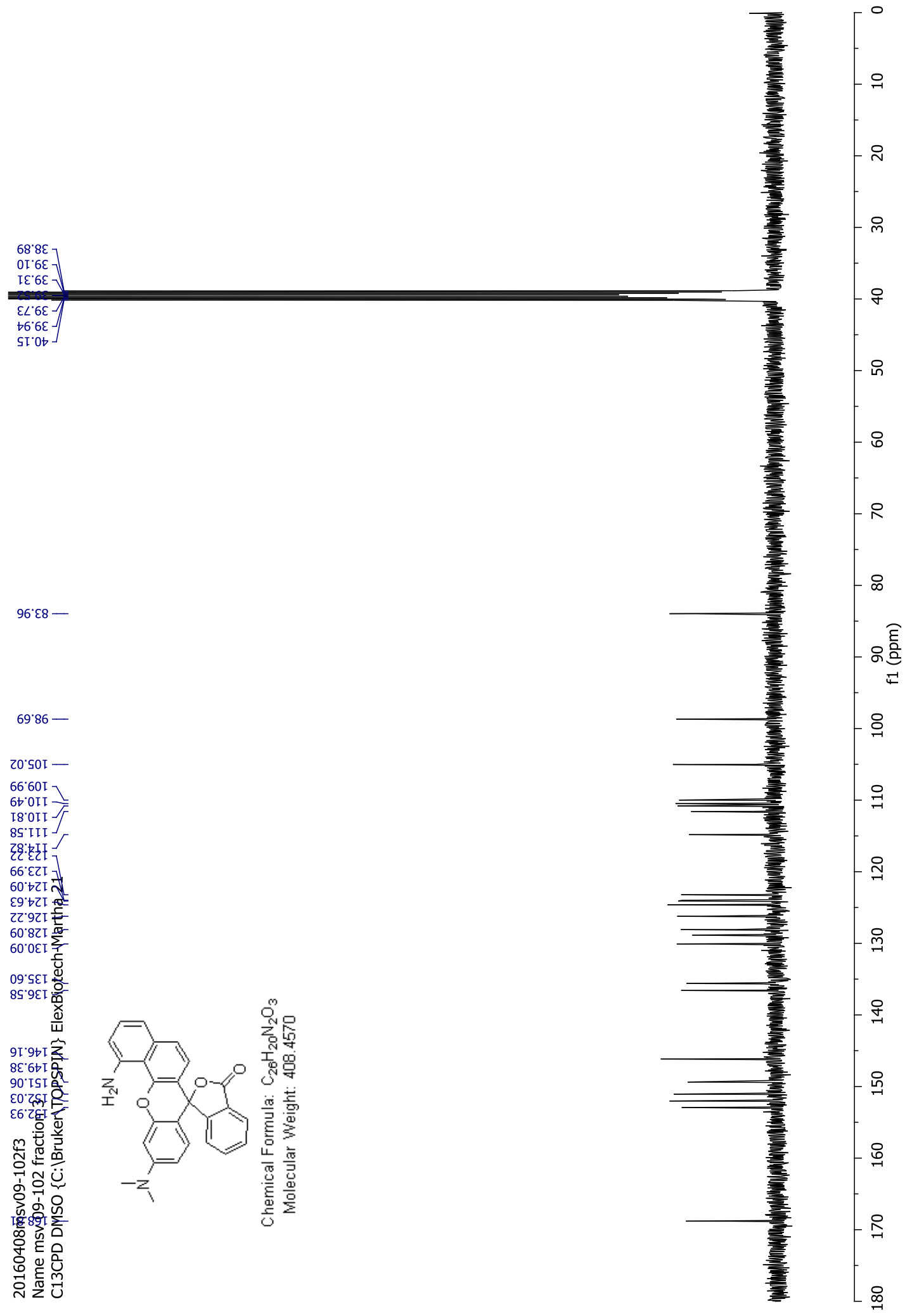

Figure A58 ${ }^{13} \mathrm{C}$ NMR spectrum of compound $\mathbf{3 8}$ 


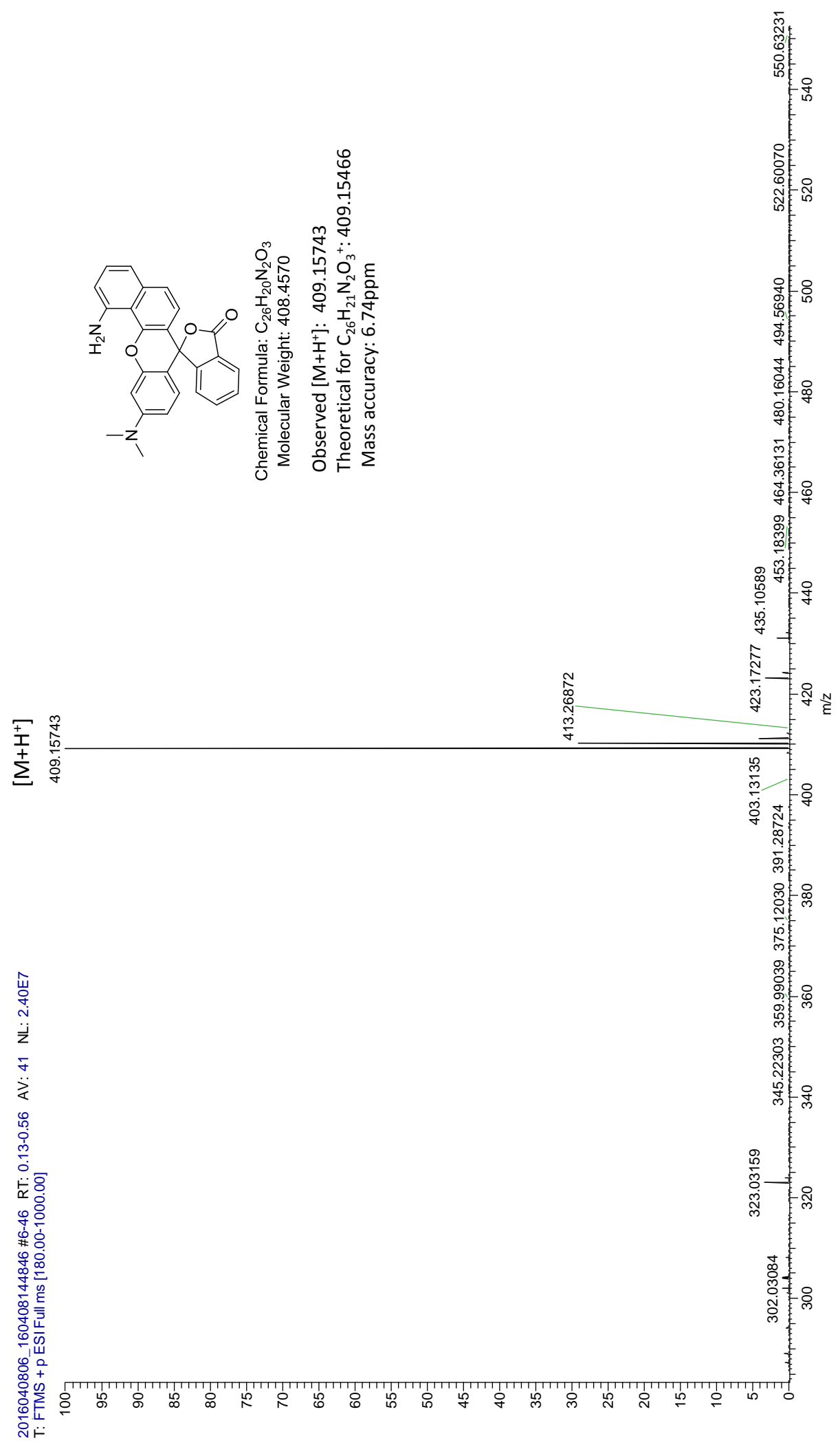

Figure A59 HR ESI positive mode spectrum of compound 38 


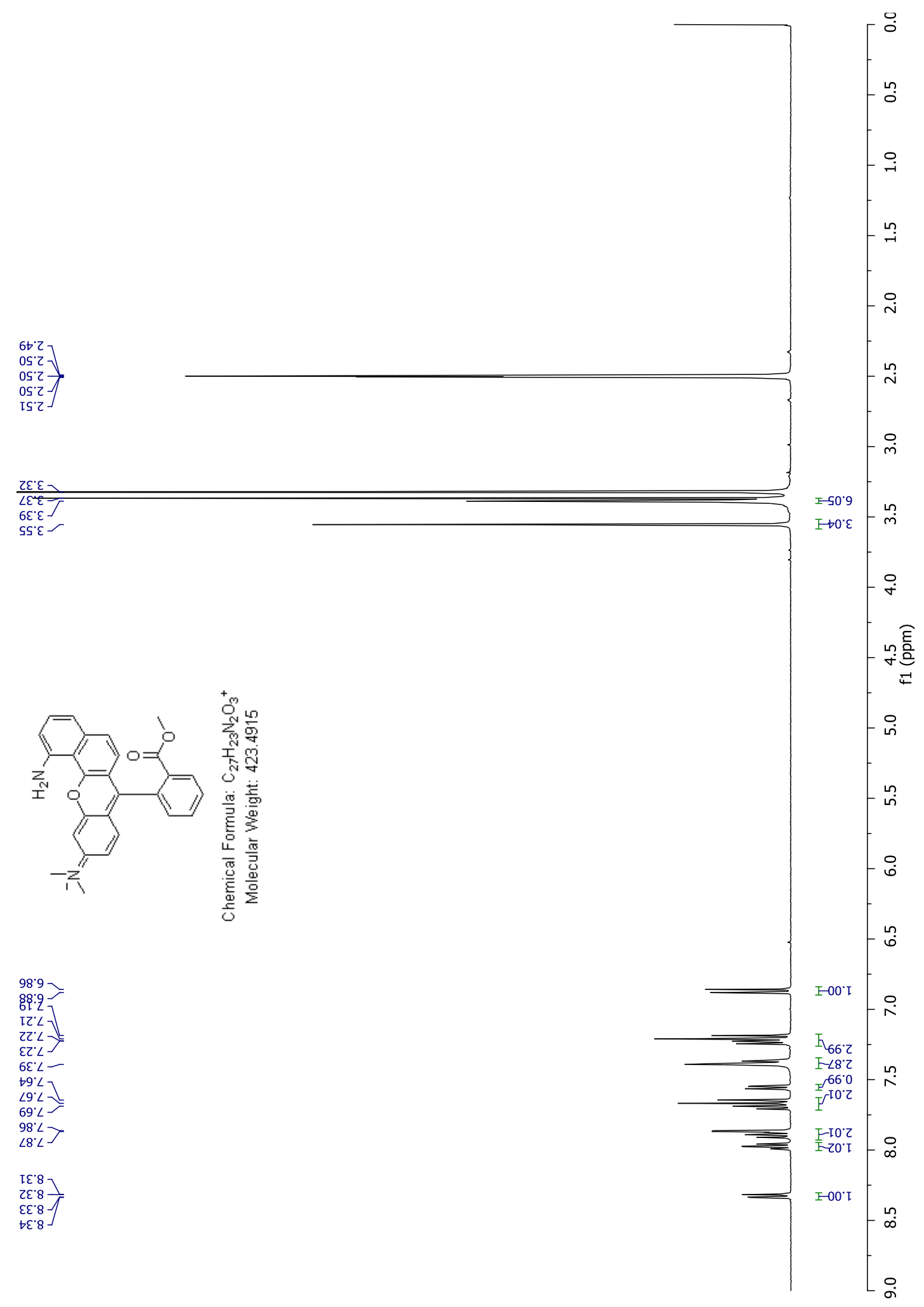

Figure A60 ${ }^{1} \mathrm{H}$ NMR spectrum of compound $\mathbf{1 0}$ 


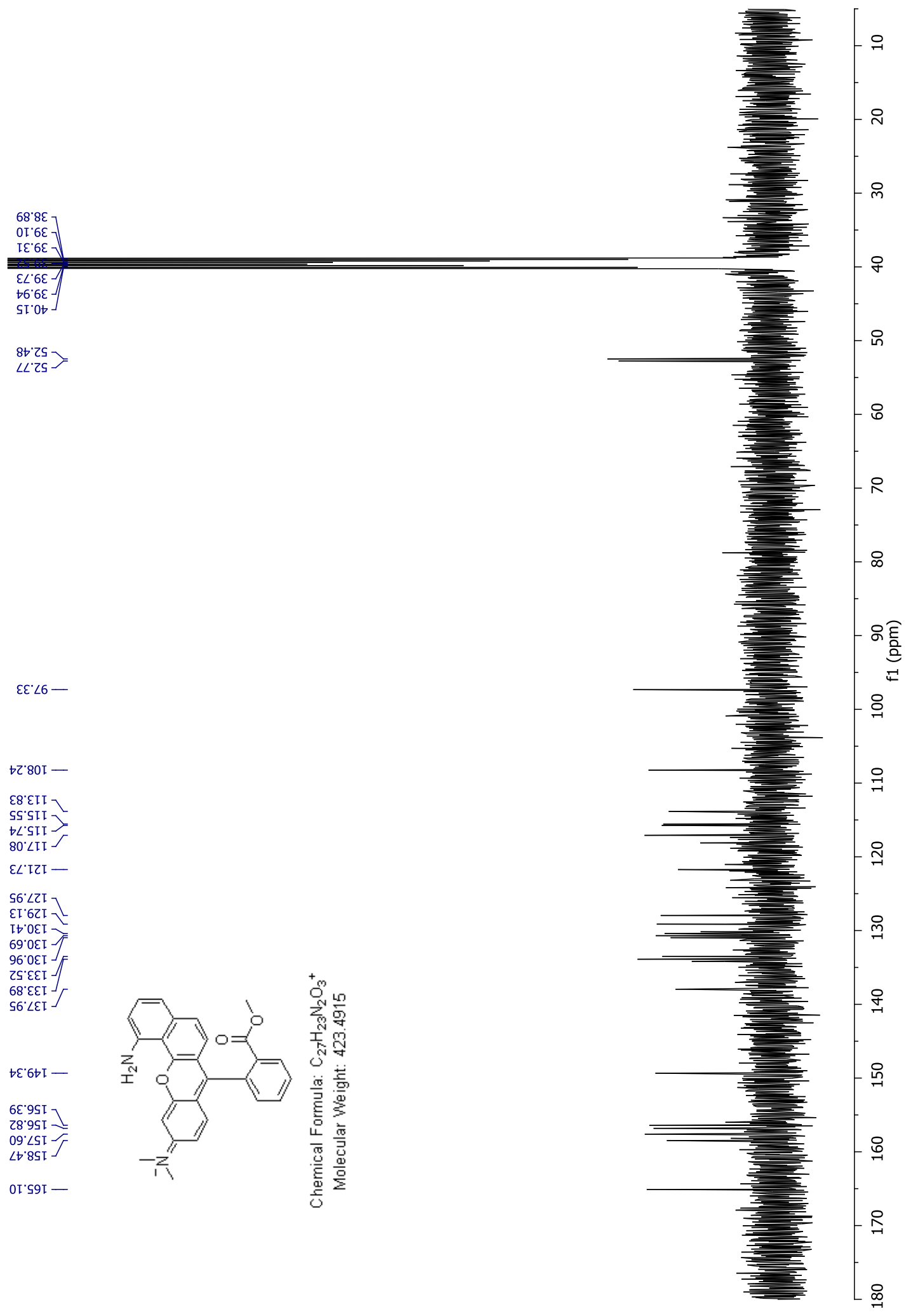

Figure A61 ${ }^{1} \mathrm{H}$ NMR spectrum of compound 10 

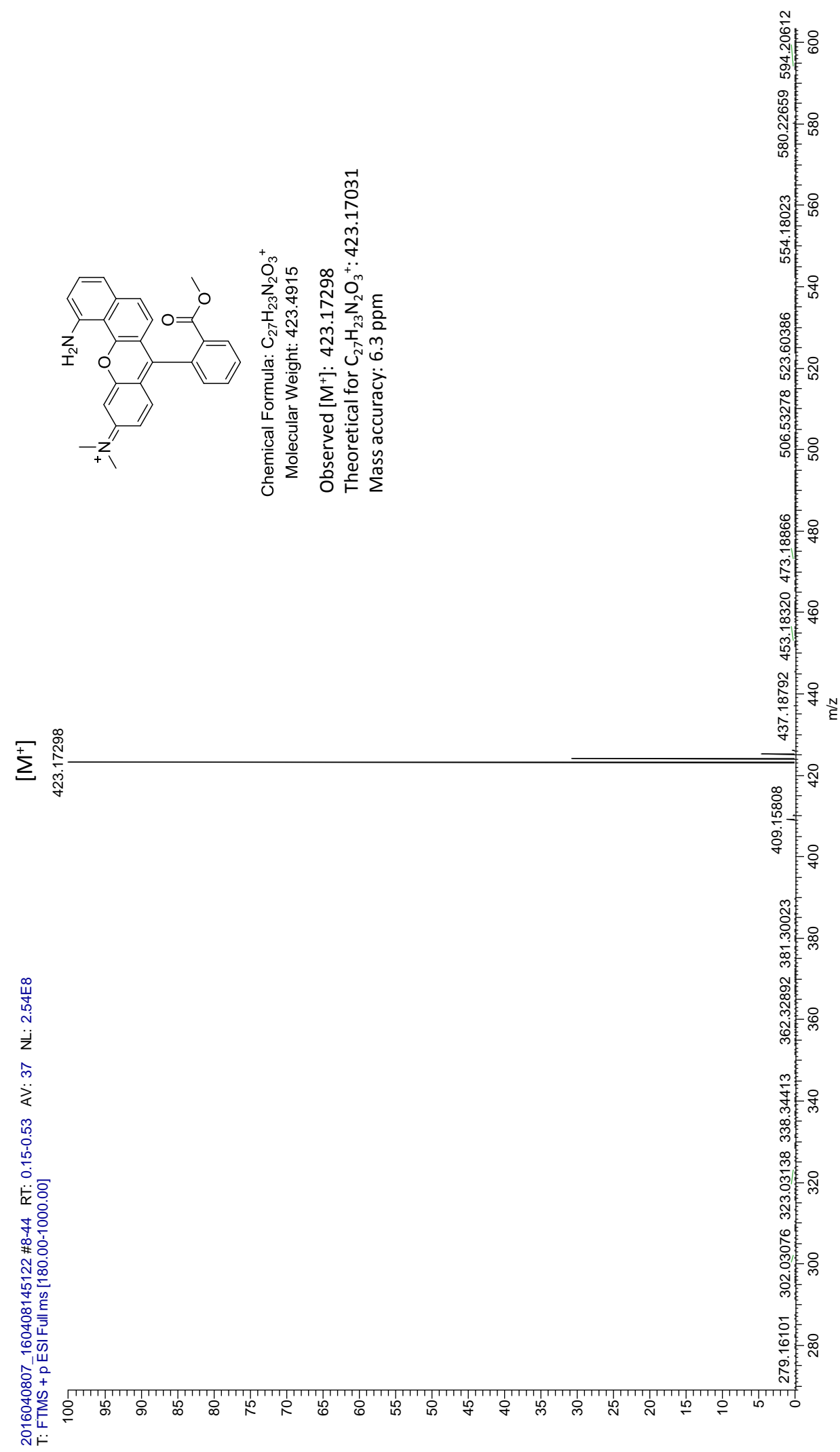

Figure A62 HR ESI positive mode spectrum of compound 10 


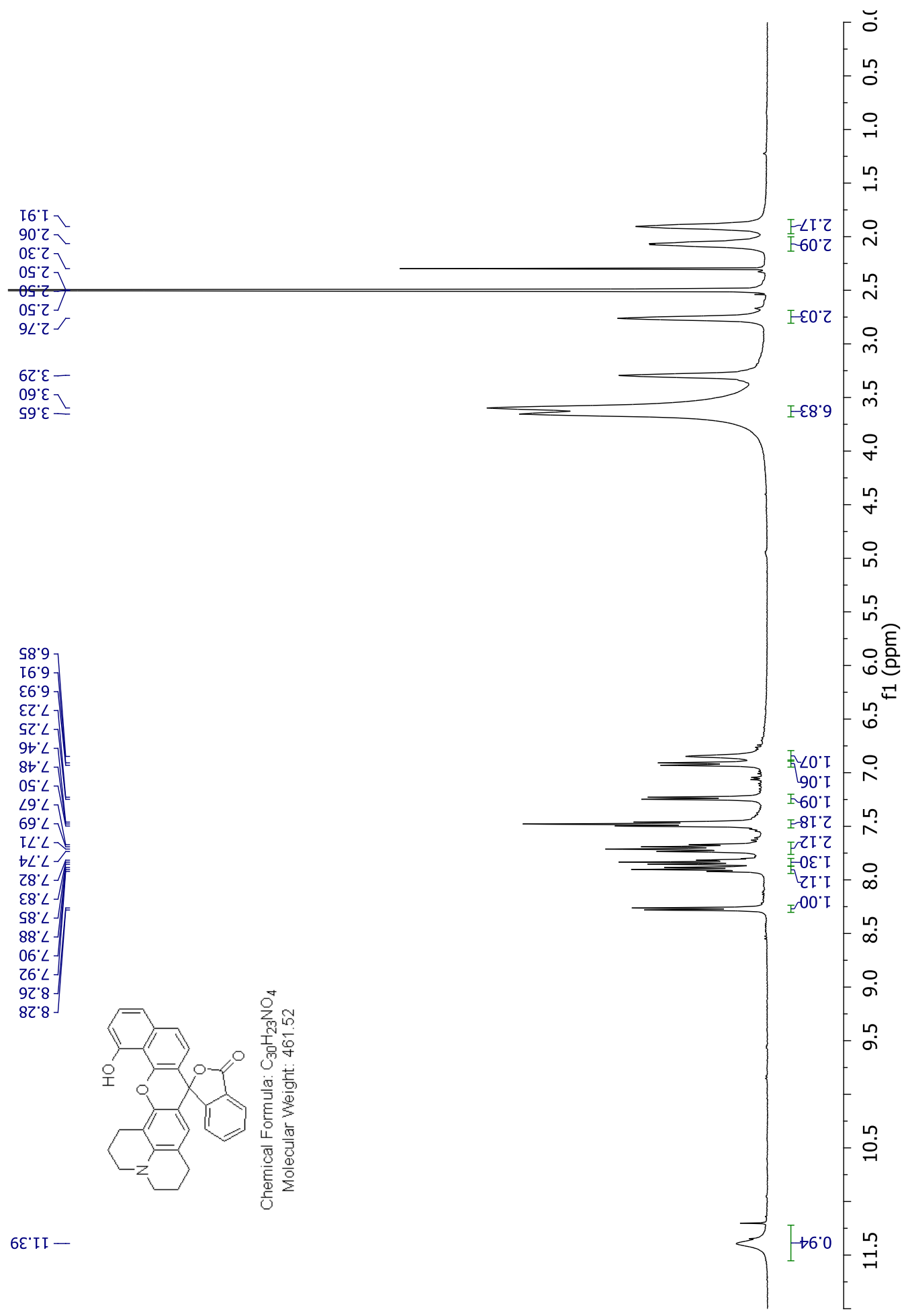

Figure A63 ${ }^{1} \mathrm{H}$ NMR spectrum of compound 39 

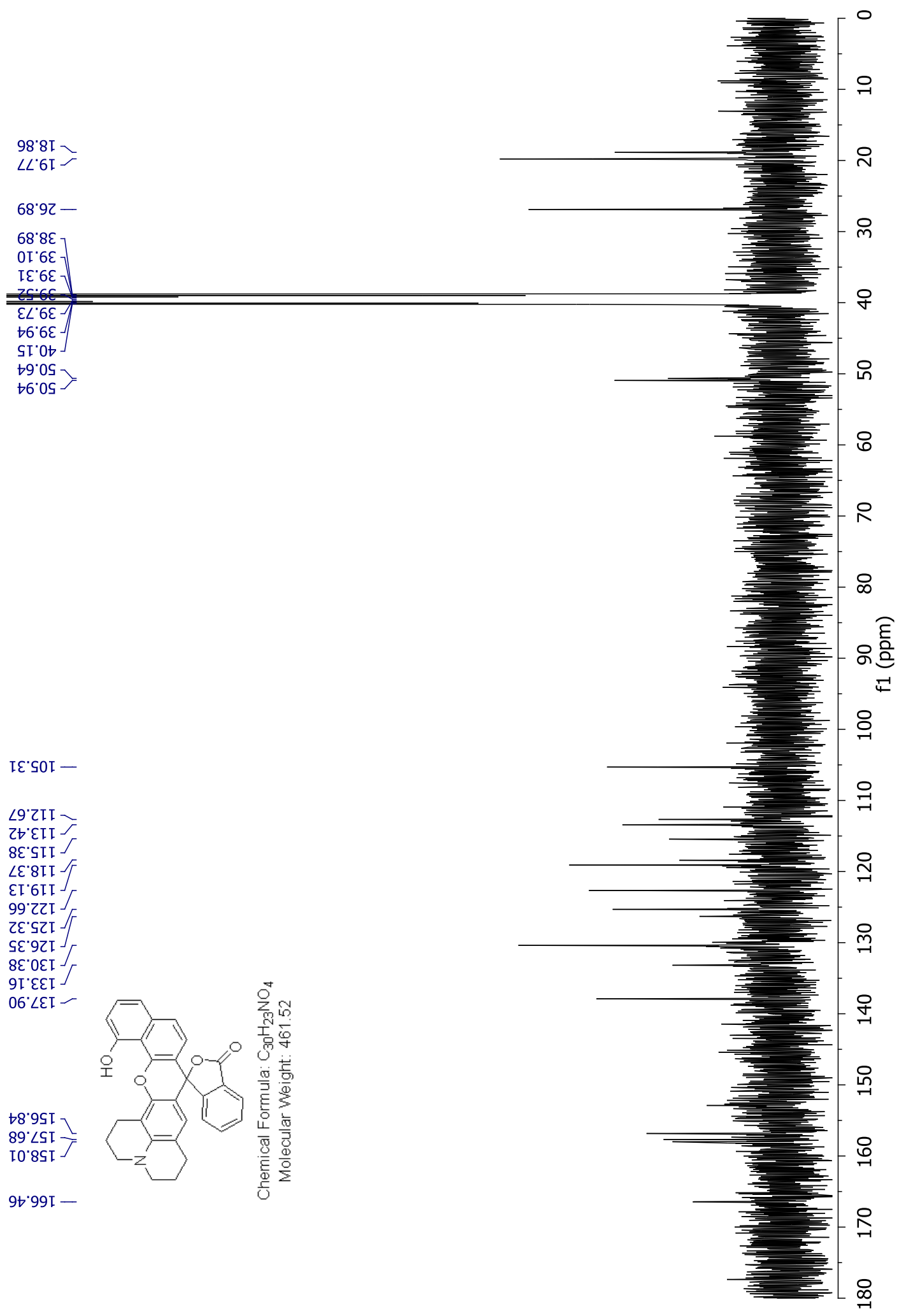

Figure A64 ${ }^{13} \mathrm{C}$ NMR spectrum of compound 39 

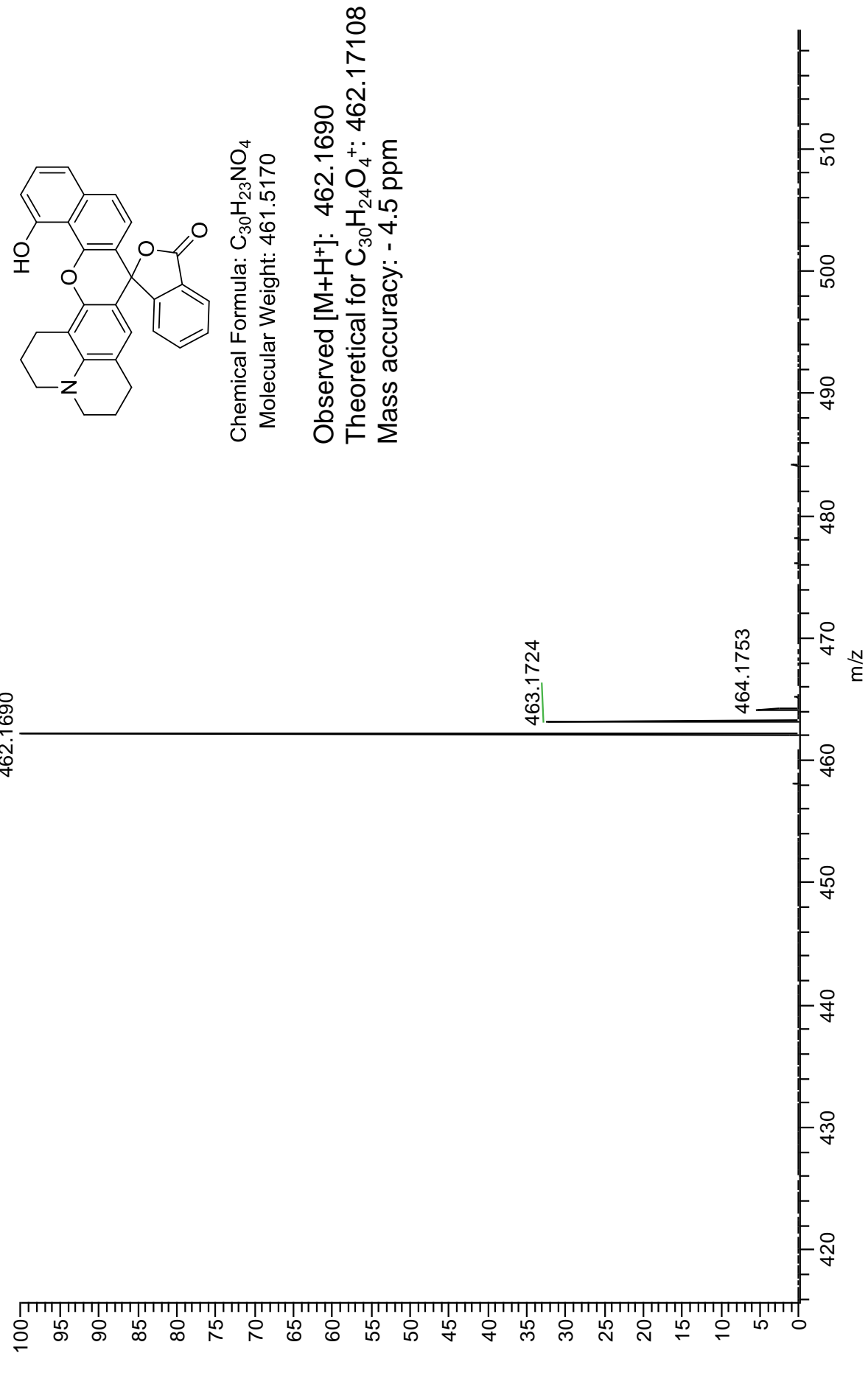

Figure A65 HR ESI positive mode spectrum of compound 39 


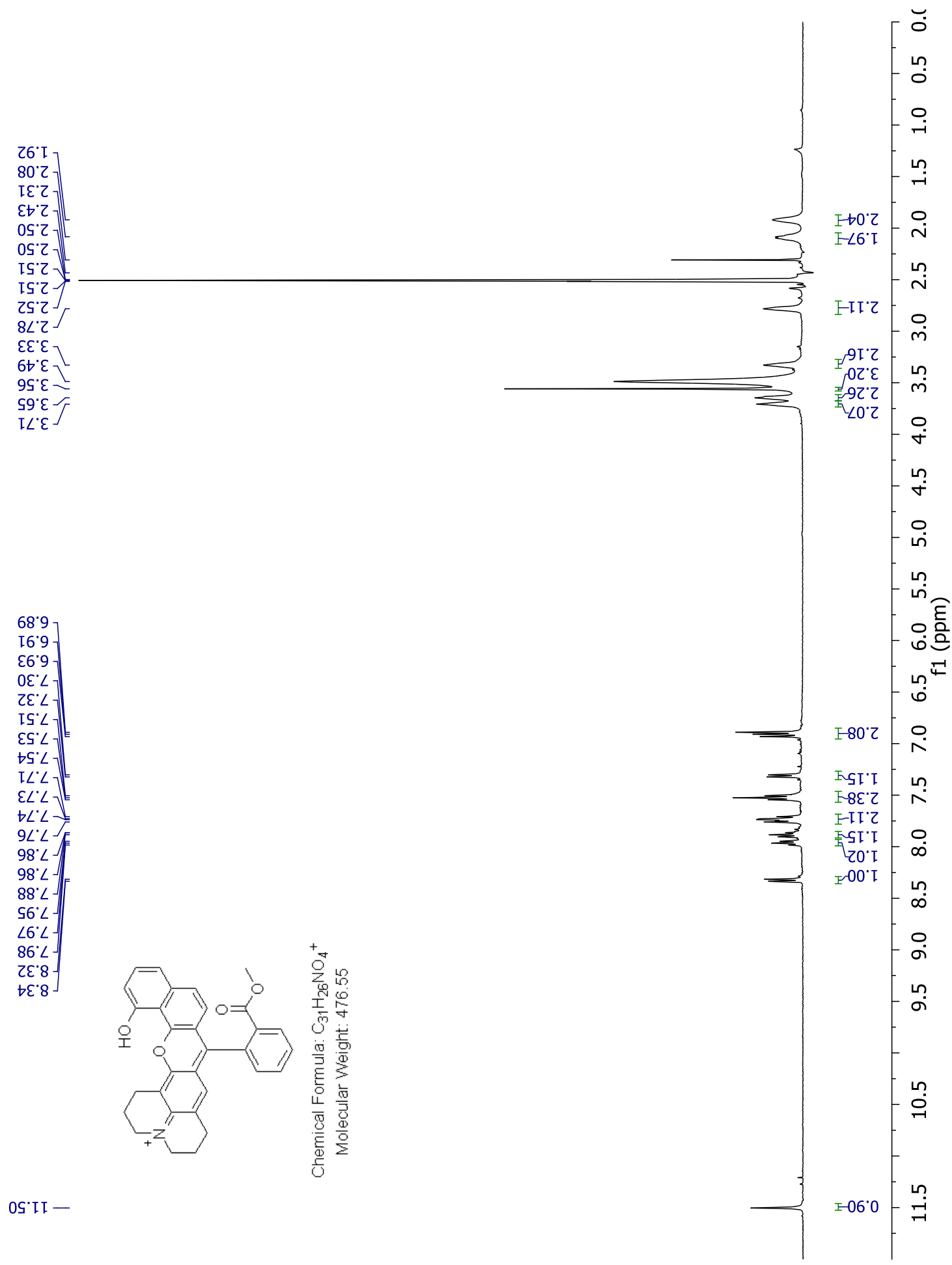

Figure A66 ${ }^{1} \mathrm{H}$ NMR spectrum of compound 11 


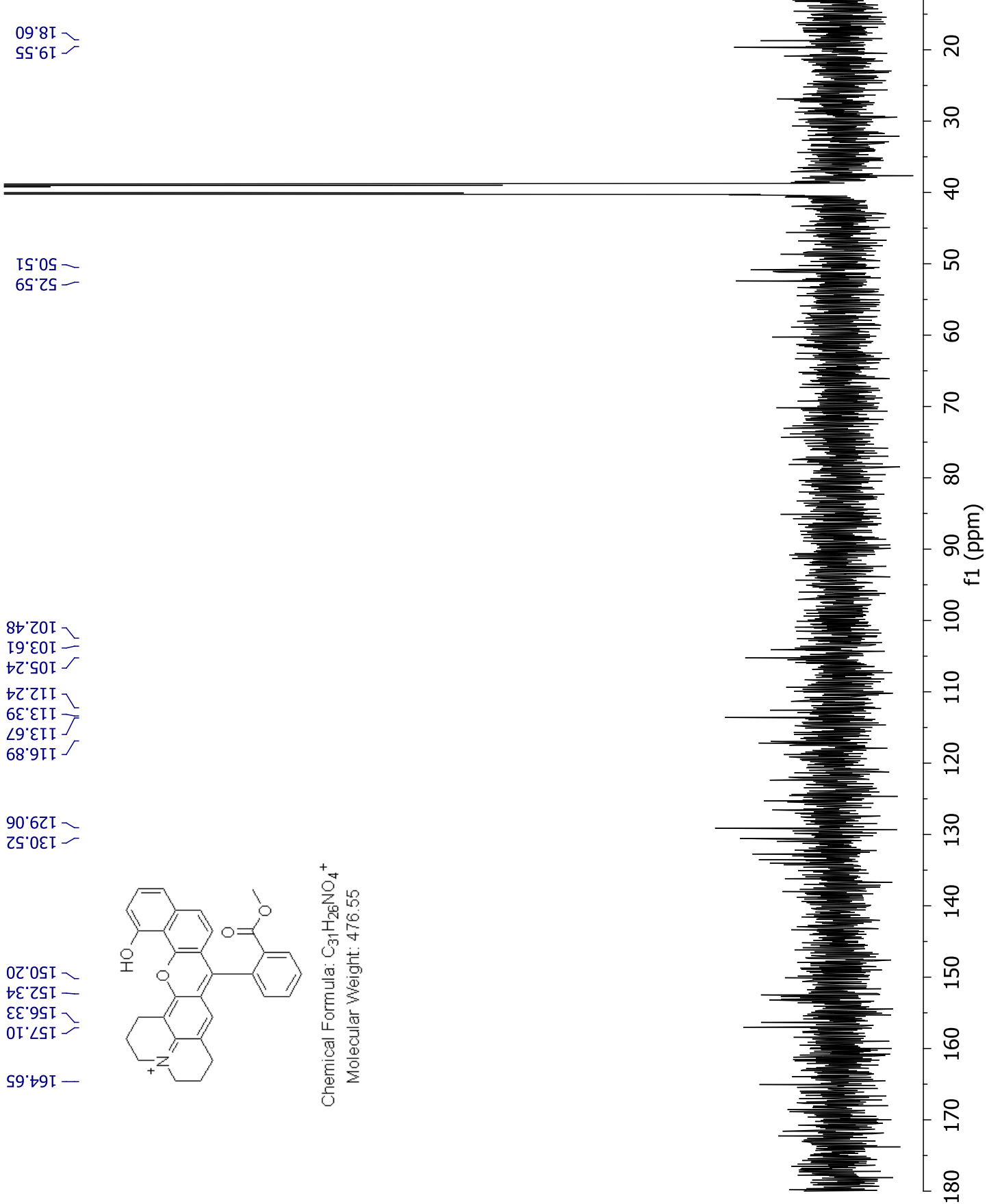

Figure A67 ${ }^{13} \mathrm{C}$ NMR spectrum of compound 11 


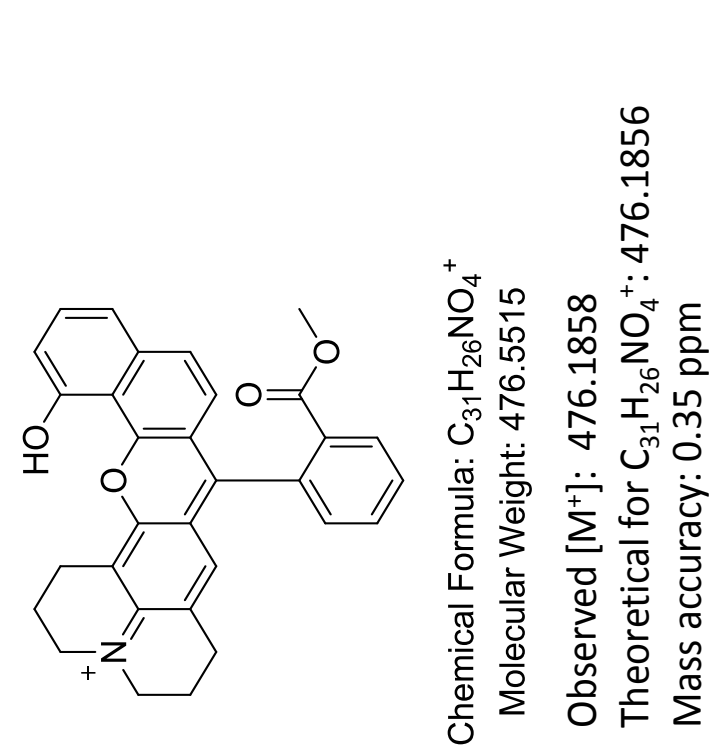

焉

ำ

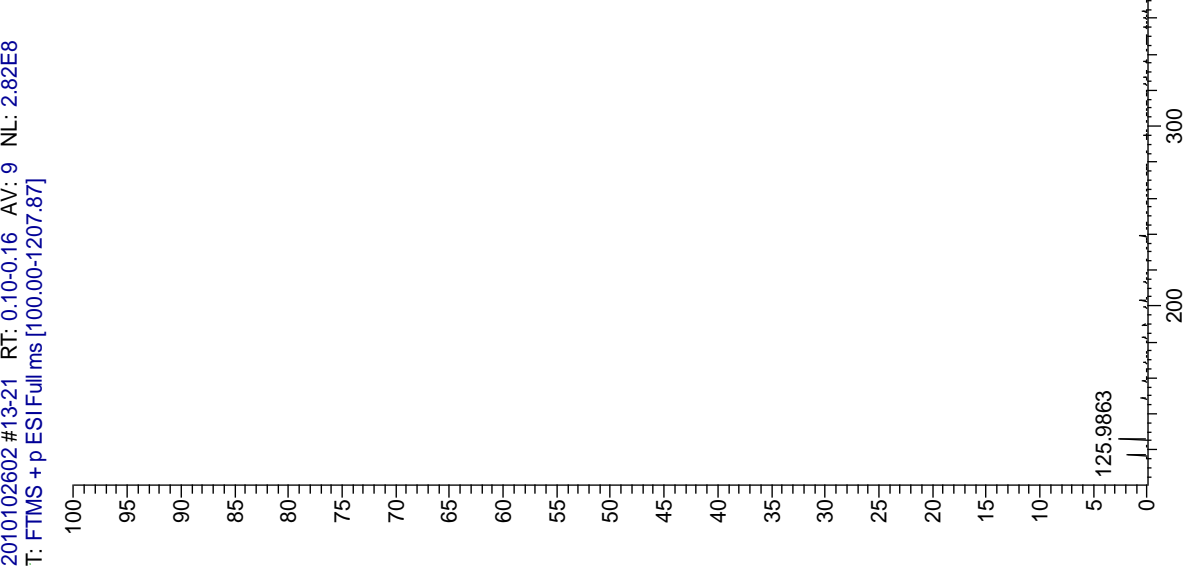

Figure A68 HR ESI positive mode spectrum of compound 11 


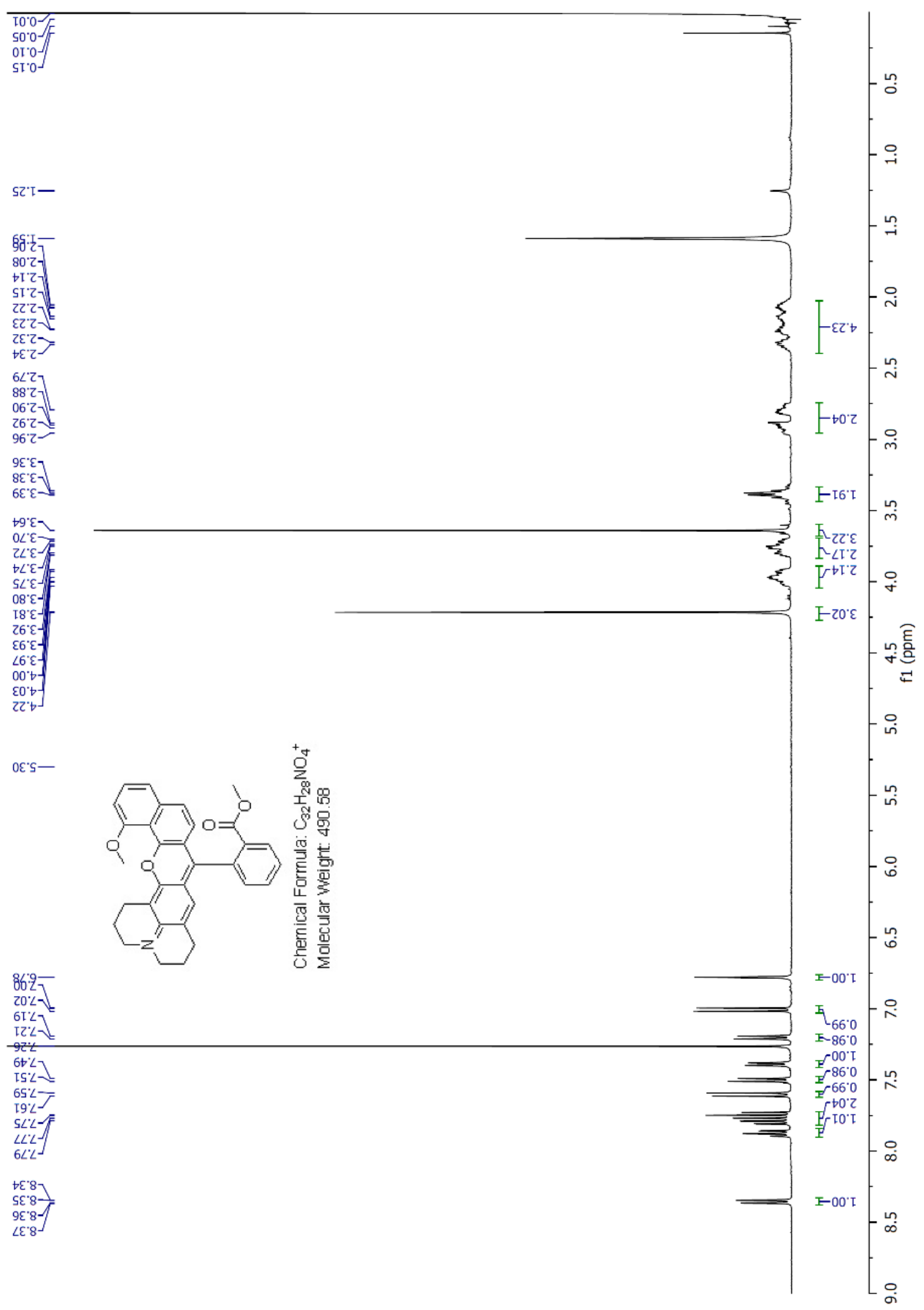

Figure A69 ${ }^{1} \mathrm{H}$ NMR spectrum of compound 12 

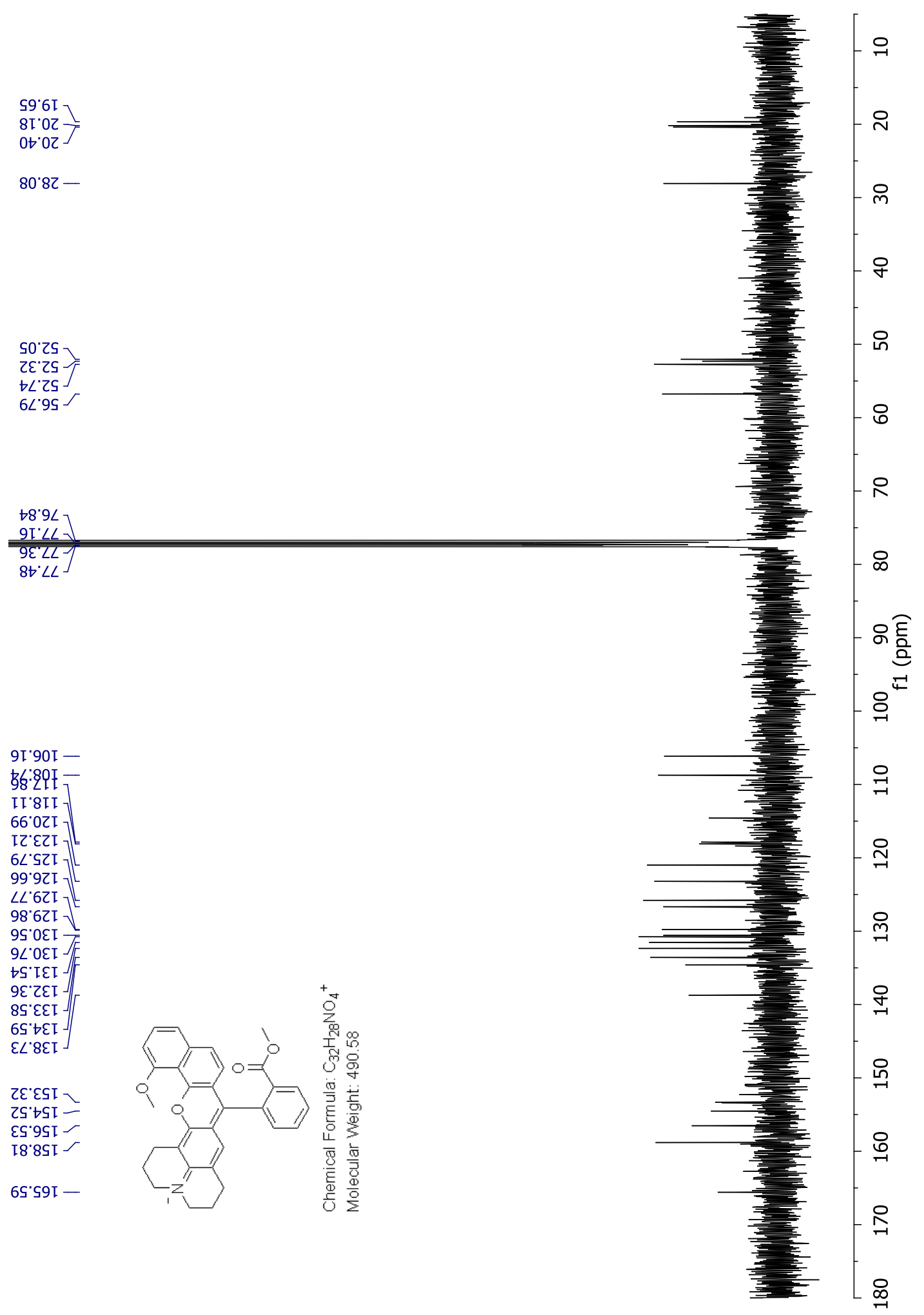

Figure A70 ${ }^{1} \mathrm{H}$ NMR spectrum of compound 12 

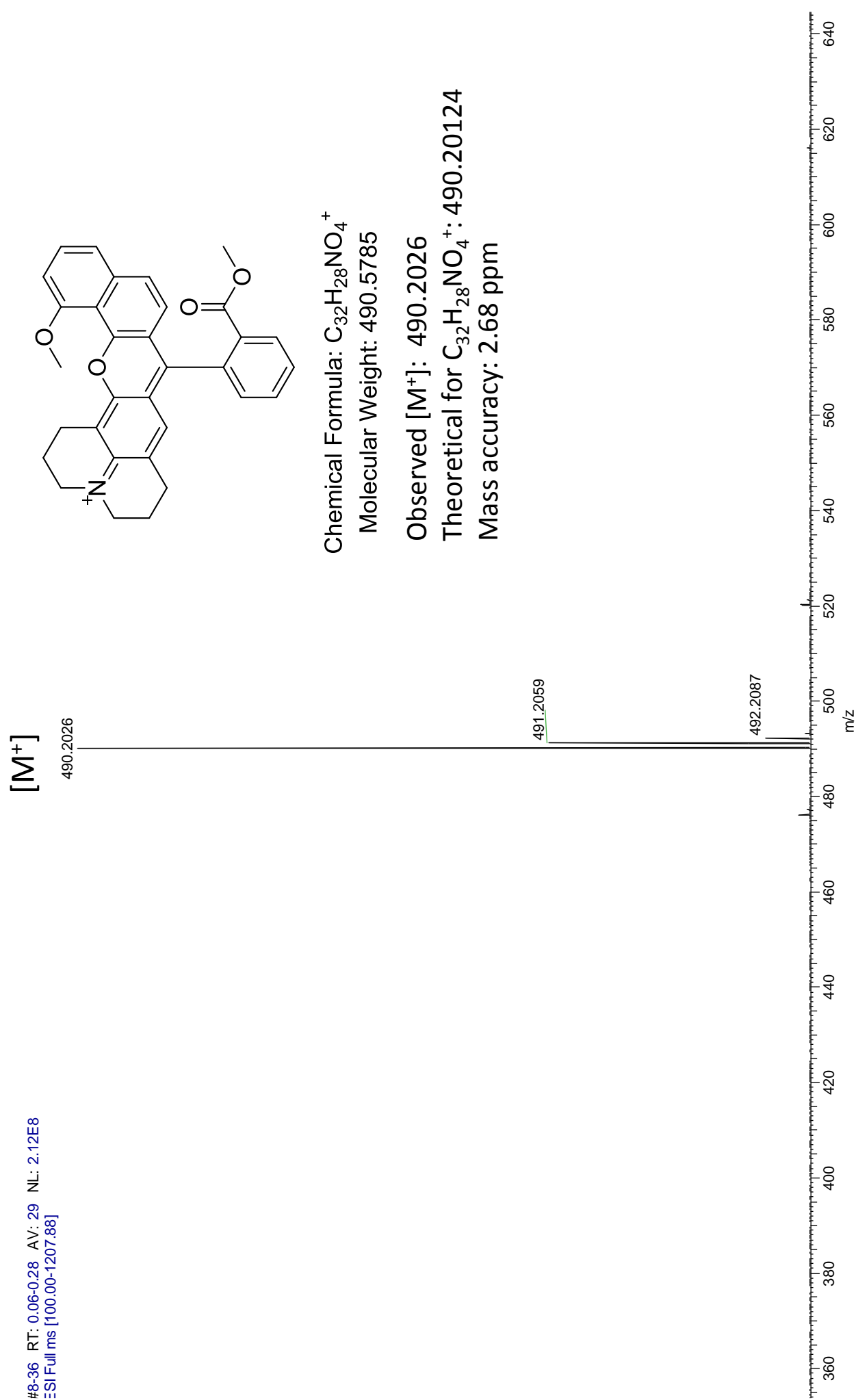

Figure A71 HR ESI positive mode spectrum of compound 12 


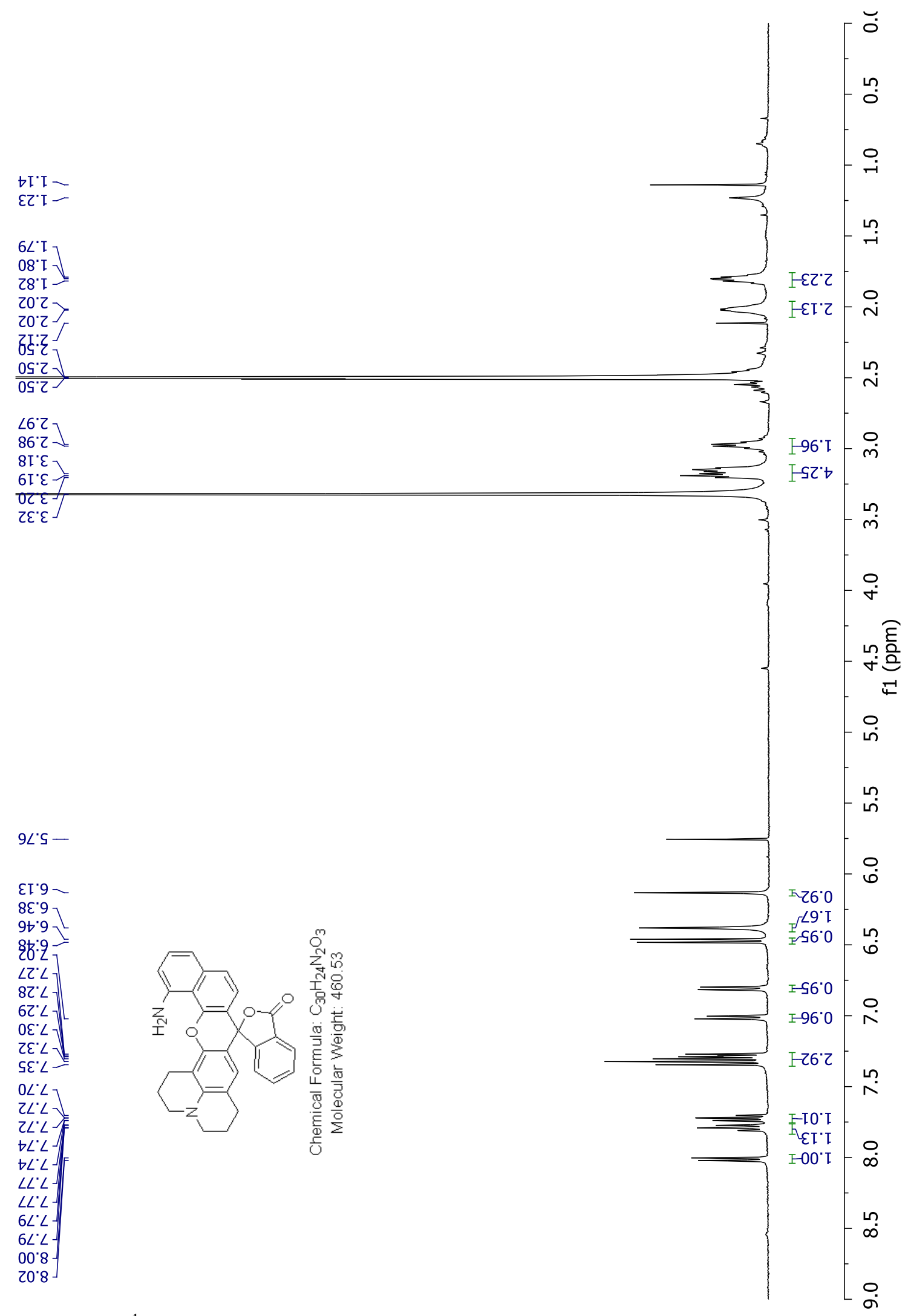

Figure A72 ${ }^{1} \mathrm{H}$ NMR spectrum of compound $\mathbf{4 0}$ 


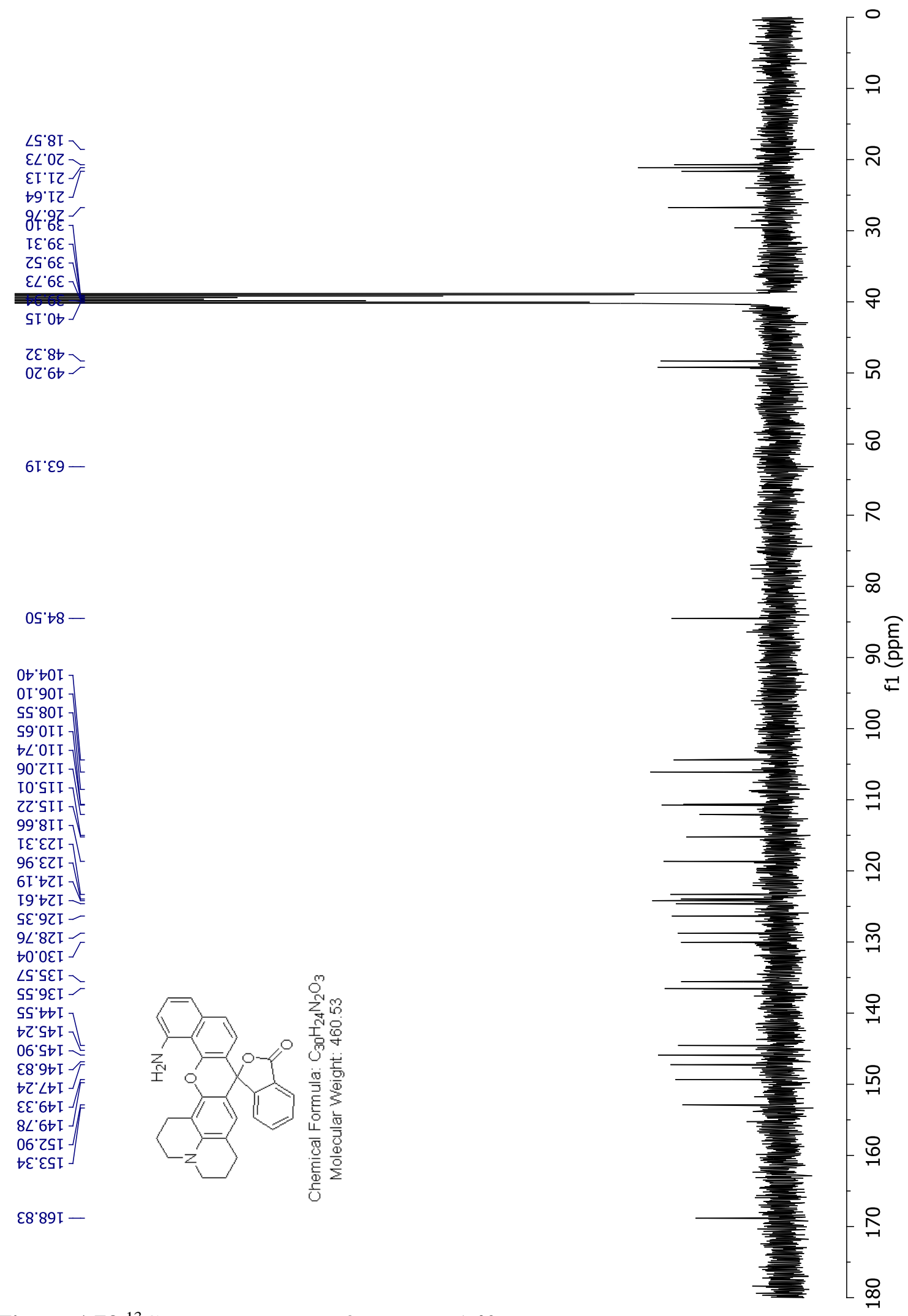

Figure $A 73{ }^{13} \mathrm{C}$ NMR spectrum of compound 40 

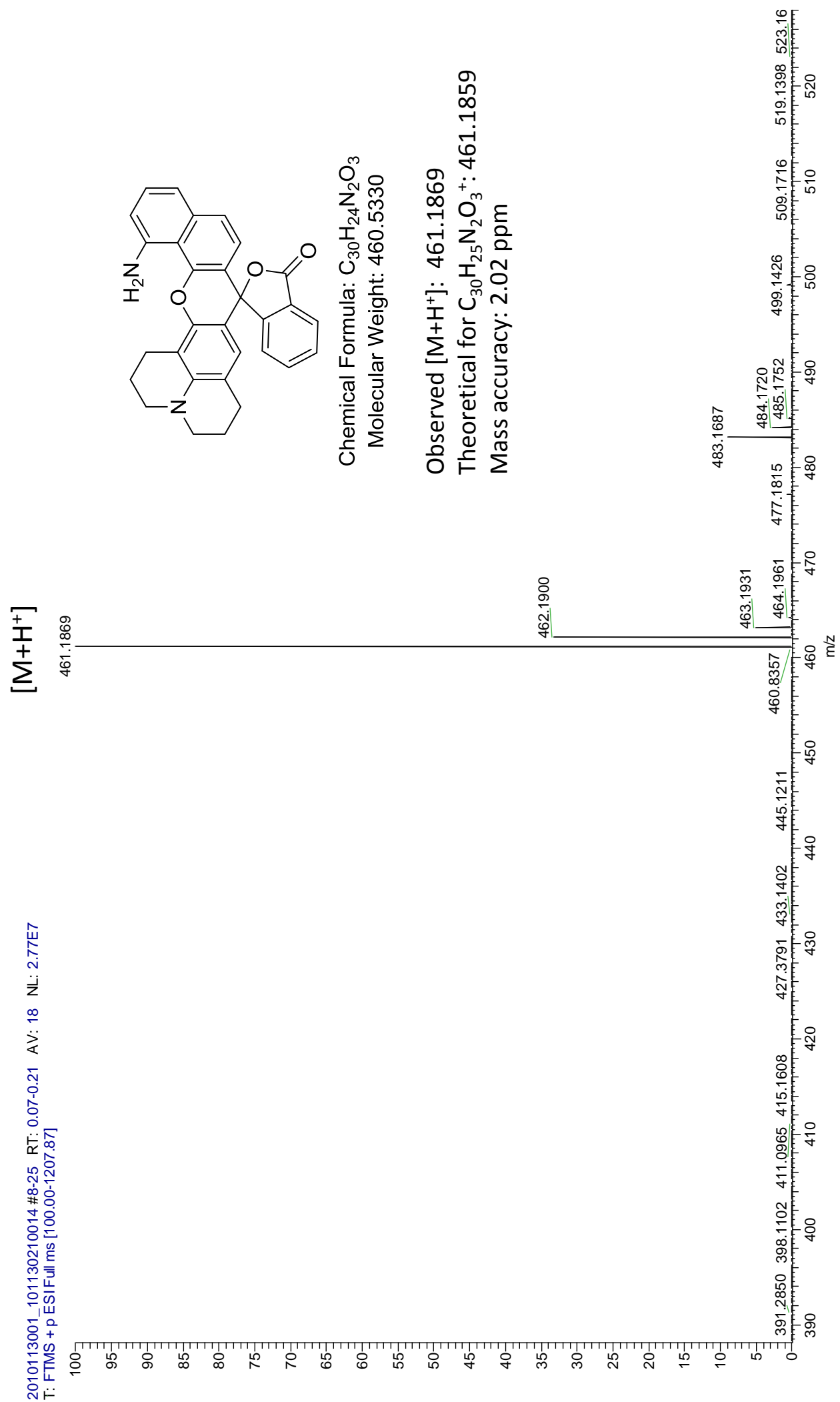

Figure A74 HR ESI positive mode spectrum of compound 40 


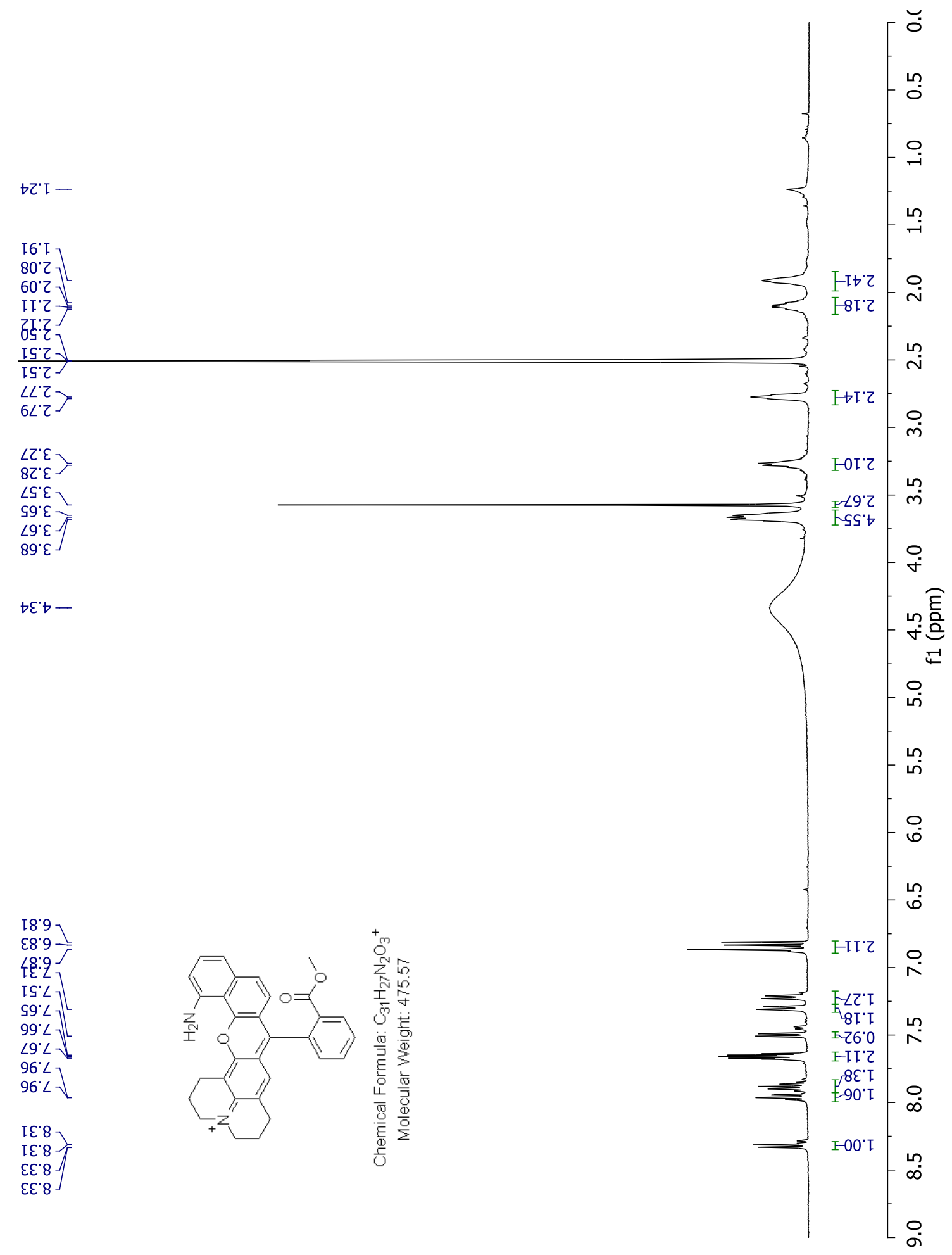

Figure A75 ${ }^{1} \mathrm{H}$ NMR spectrum of compound $\mathbf{1 3}$ 


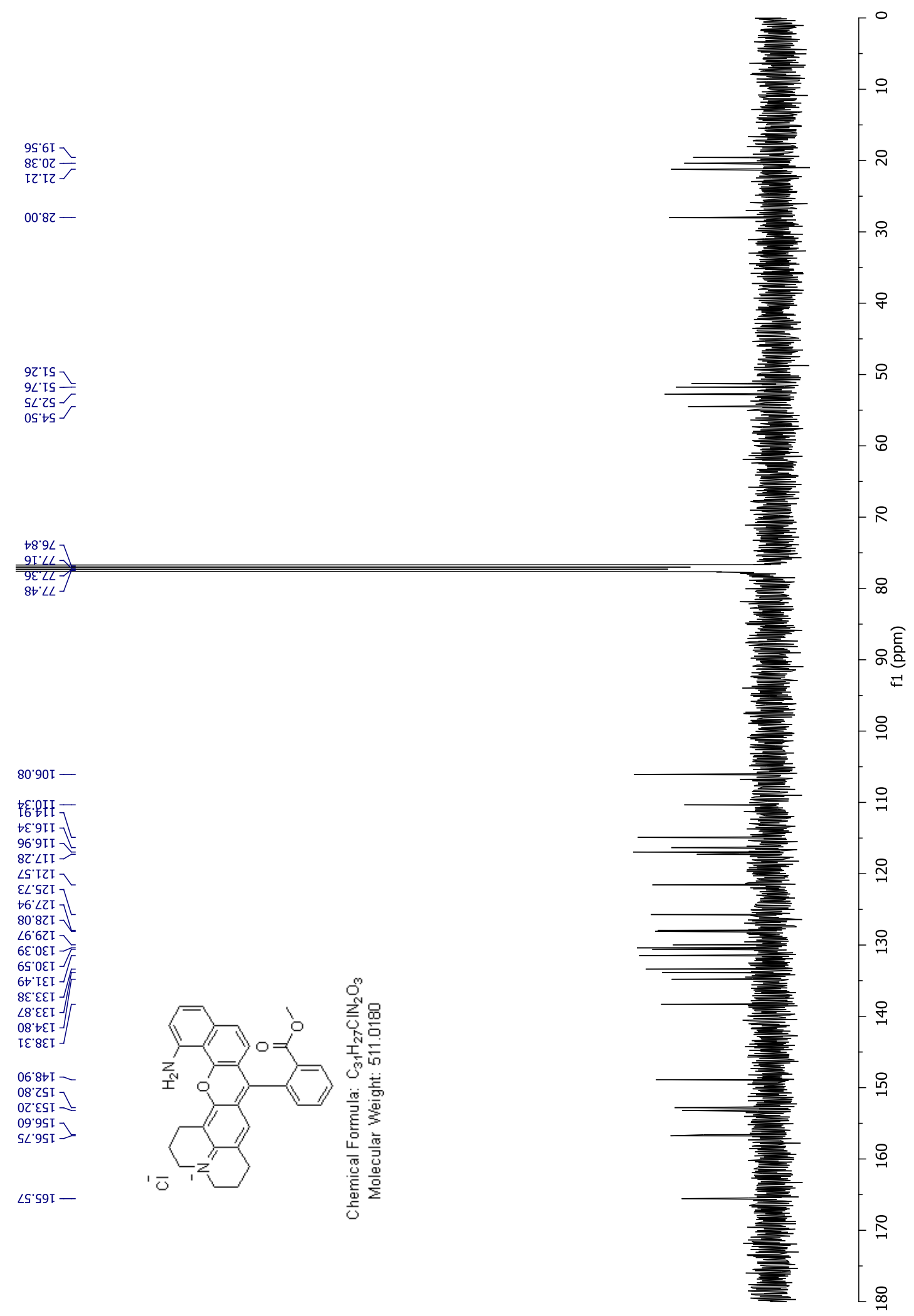

Figure A76 ${ }^{13} \mathrm{C}$ NMR spectrum of compound $\mathbf{1 3}$ 

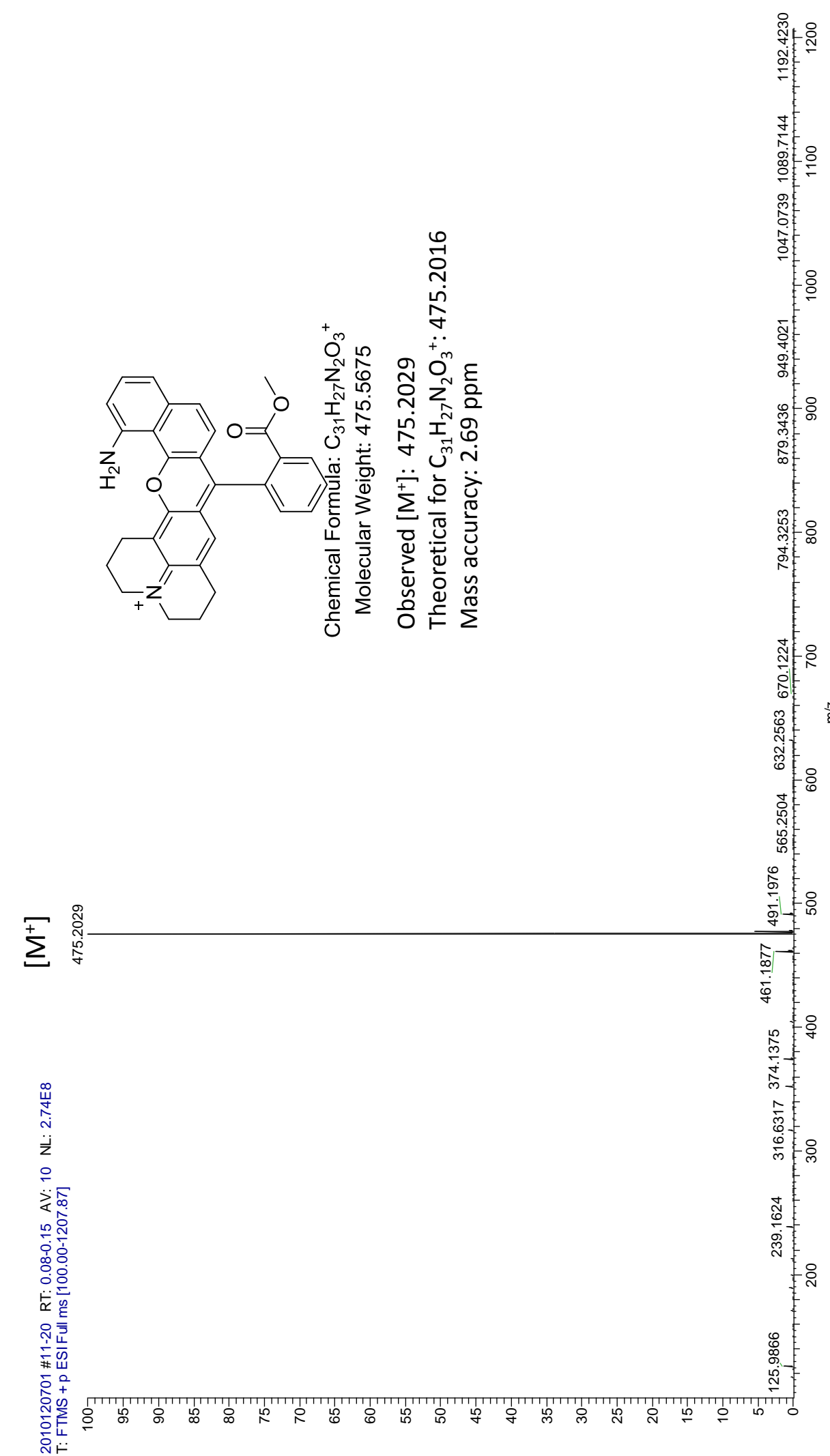

Figure A77 HR ESI positive mode spectrum of compound 13 